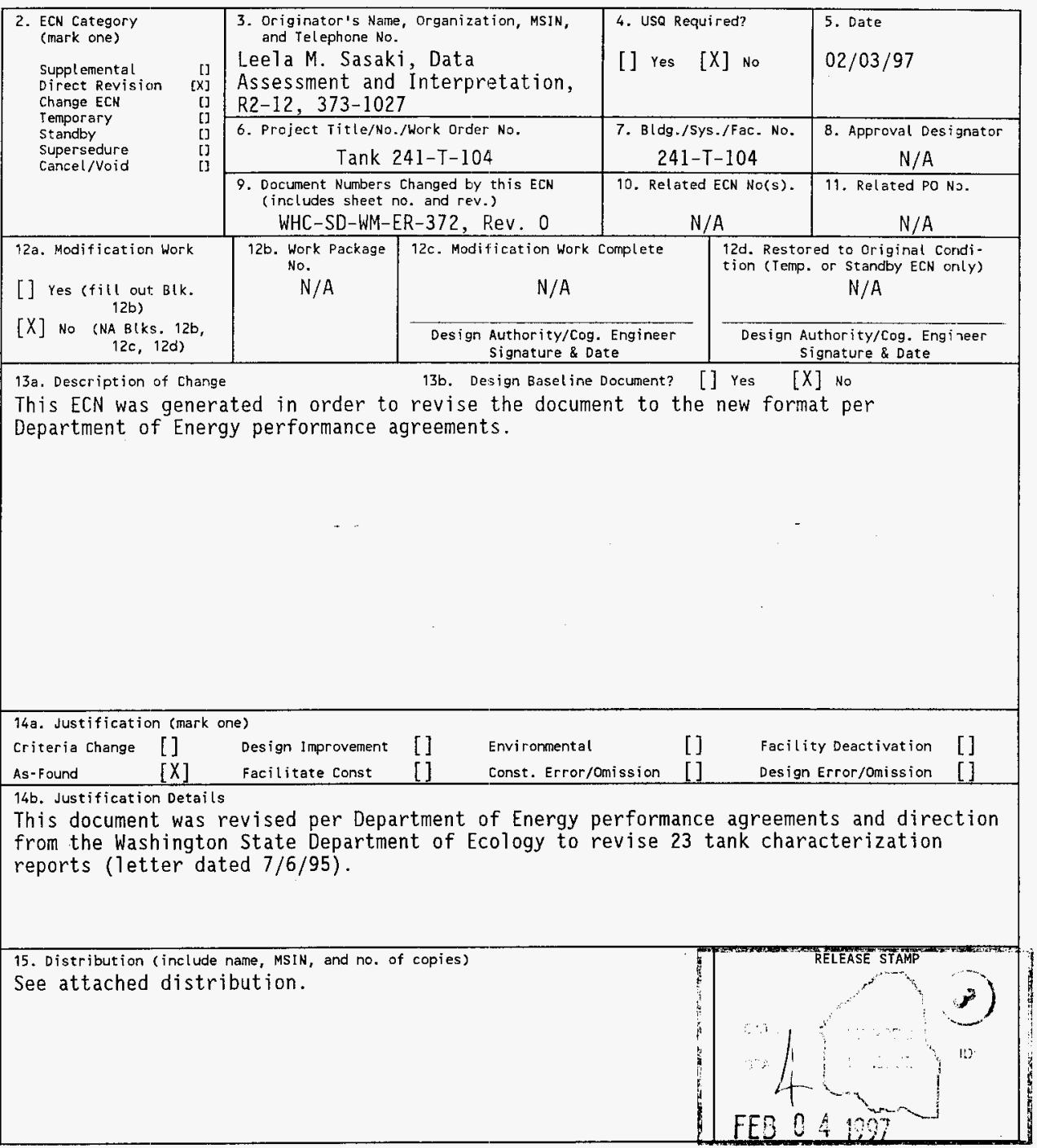




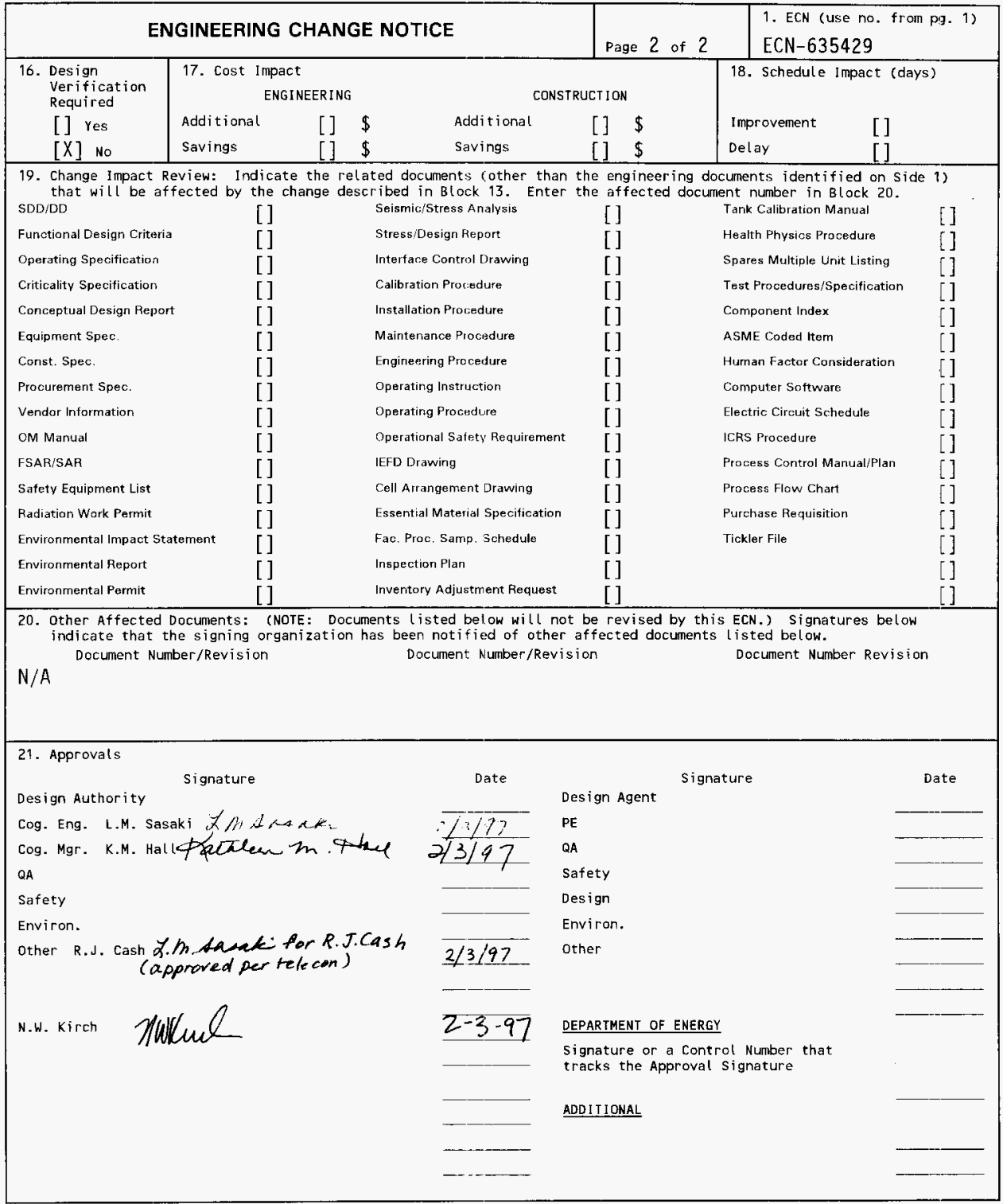




\section{Tank Characterization Report for Single-Shell Tank 241-T-104}

\section{Leela M. Sasaki}

Lockheed Martin Hanford Corp., Richland, WA 99352

U.S. Department of Energy Contract DE-AC06-87RL10930

EDT/ECN: $\quad$ ECN-635429

UC: 2070

Org Code: 74620

B\&R Code: EW 3120074

Charge Code: N4G4C

Total Pages: 195 tane $3 / 4 / 77$

Key Words: Waste Characterization, Single--Shel1 Tank, SST, Tank 241-T104, Tank T-104, T-104, T Farm, Tank Characterization Report, TCR, Waste Inventory, TPA Milestone M-44

Abstract: This document summarizes the information on the historical uses, present status, and the sampling and analysis results of waste stored in Tank 241-T-104. This report supports the requirements of the Tri-Party Agreement Milestone M-44-05.

TRADEMARK DISCLALMER. Reference herein to any specific comercial product, process, or service by trade name, trademark, manufacturer, or otherwise, does not necessarily constitute or imply its endorsement, recommendation, or favoring by the United States Governnent or any agency thereof or its contractors or subcontractors.

Printed in the United States of America. To obtain copies of this document, contact: WHC/BCS Document Control Services, P.D. Box 1970, Mailstop H6-08, Richland WA 99352, Phone (509) 372-2420; Fax (509) 376-4989.
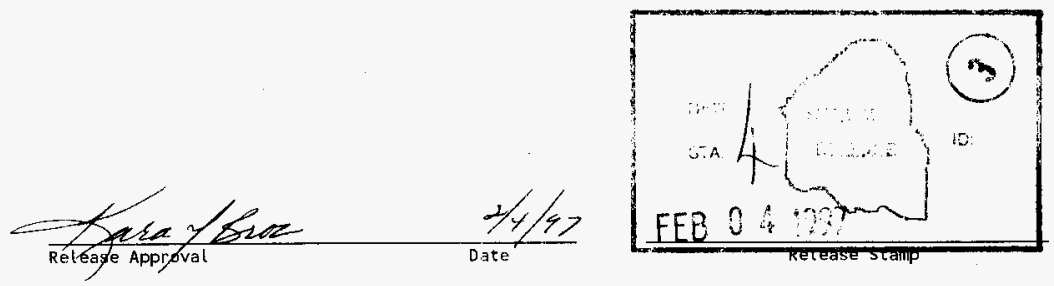

\section{Approved for Public Release}


RECORD OF REVISION

(1) Document Number

HNF-SD-WM-ER-372

Page 1

(2) Title

Tank Characterization Report for Single-She 11 Tank 241-T-104

CHANGE CONTROL RECORD

\begin{tabular}{|c|c|c|c|c|c|}
\hline \multirow{2}{*}{ (3) } & \multirow{2}{*}{ Revision } & \multirow{2}{*}{\multicolumn{2}{|c|}{ (4) Description of Change - Replace, Add, and Delete Pages }} & \multicolumn{2}{|c|}{ Authorized for Release } \\
\hline & & & & (5) Cog. Engr. & (6) Cog. Mgr. \\
\hline & 0 & & $\begin{array}{l}\text { Initially released } 09 / 29 / 94 \text { on EDT- } \\
159087 \text {. }\end{array}$ & $\begin{array}{l}\text { B.C. } \\
\text { Simpson }\end{array}$ & C.S. Haller \\
\hline & 1 RS & & Incorporate per ECN-635429. & 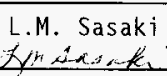 & $\begin{array}{l}\text { K.M. Ha11 } 2 / 3 / 97 \\
\text { faccheewh } 7 \text { taed }\end{array}$ \\
\hline & & & & & \\
\hline & & & & & \\
\hline & & & & & \\
\hline & & & & & \\
\hline & & & & & \\
\hline & & & & & \\
\hline & & & & & \\
\hline & & & & & \\
\hline & & & & & \\
\hline & & & & & \\
\hline & & & & & \\
\hline & & & & & \\
\hline & & & & & \\
\hline & & & & & \\
\hline & & & & & \\
\hline & & & & & \\
\hline & & & & & \\
\hline & & & & & \\
\hline & & & & & \\
\hline & & & & & \\
\hline & & & & & \\
\hline & & & & & \\
\hline & & & & & \\
\hline & & & & & \\
\hline & & & & & \\
\hline & & & & & \\
\hline & & & & & \\
\hline & & & & & \\
\hline & 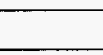 & & & & \\
\hline
\end{tabular}




\section{Tank Characterization Report for Single-Shell Tank 241-T-104}

L. M. Sasaki

Lockheed Martin Hanford Corporation

J. D. Franklin

Los Alamos Technical Associates

\section{J. L. Stroup}

Fluor Daniel Northwest

L. Jensen

Numatec Hanford Corporation

R. T. Winward

Meier Associates

Date Published

January 1997

Prepared for the U.S. Department of Energy

Assistant Secretary for Environmental Management

Project Hanford Management Contractor for the

U.S. Department of Energy under Contract DE-AC06-96RL13200

Approved for public release; distribution is unlimited 


\section{CONTENTS}

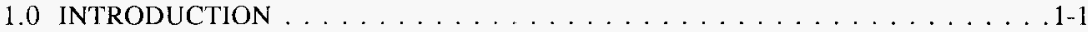

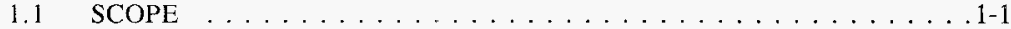

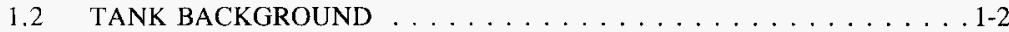

2.0 RESPONSE TO TECHNICAL ISSUES $\ldots \ldots \ldots \ldots \ldots \ldots \ldots \ldots \ldots$

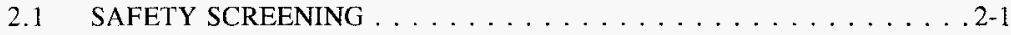

2.1.1 Exothermic Conditions (Energetics) . . . . . . . . . . . 2-1

2.1 .2 Flammable Gas . . . . . . . . . . . . . . . . . . . 2-2

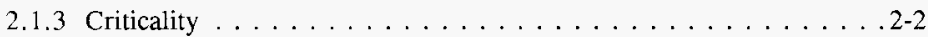

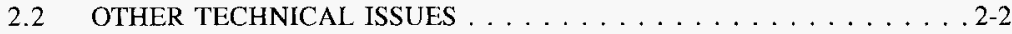

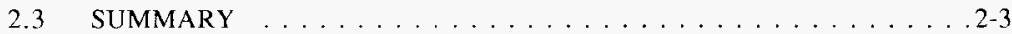

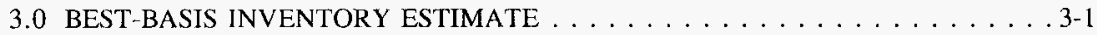

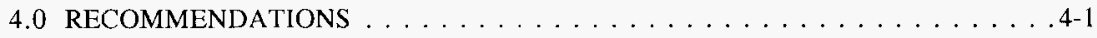

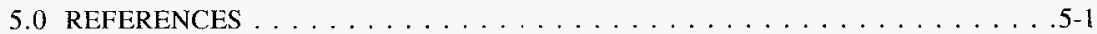

APPENDIXES

APPENDIX A: HISTORICAL TANK INFORMATION ............. A-1

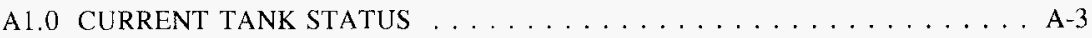

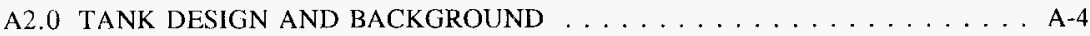

A3.0 PROCESS KNOWLEDGE $\ldots \ldots \ldots \ldots \ldots \ldots \ldots \ldots \ldots \ldots \ldots$

A3.1 WASTE TRANSFER HISTORY . . . . . . . . . . . A A 9

A3.2 HISTORICAL ESTIMATION OF TANK CONTENTS . . . . . . . A A-10

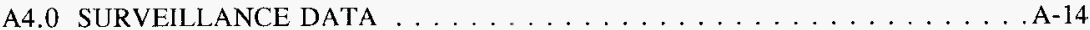

A4. 1 SURFACE-LEVEL READINGS . . . . . . . . . . . . . . A-14 . . . . . . . . . . . .

A4.2 INTERNAL TANK TEMPERATURES . . . . . . . . . . . . . . A-14

A4.3 TANK 241-T-104 PHOTOGRAPHS . . . . . . . . . . A-15

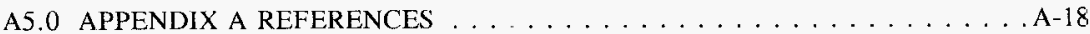




\section{CONTENTS (Continued)}

APPENDIX B: SAMPLING OF TANK $241-\mathrm{T}-104 \ldots \ldots \ldots \ldots \ldots$ B-1

B1.0 TANK SAMPLING OVERVIEW $\ldots \ldots \ldots \ldots \ldots \ldots \ldots \ldots$

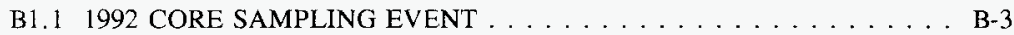

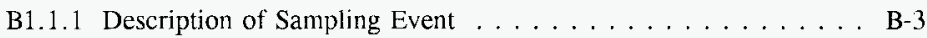

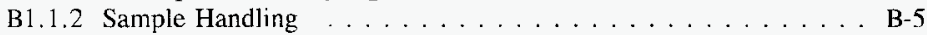

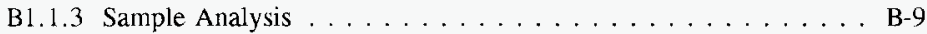

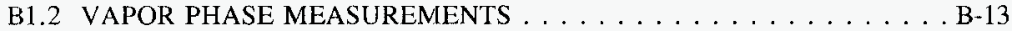

B1.3 DESCRIPTION OF HISTORICAL SAMPLING EVENT . . . . . . . B-13

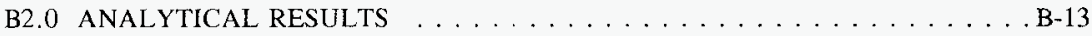

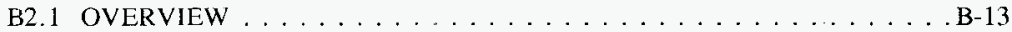

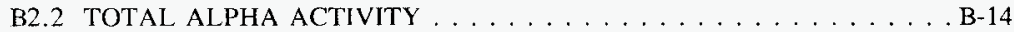

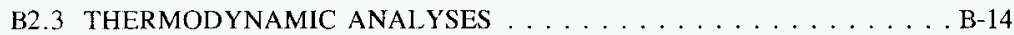

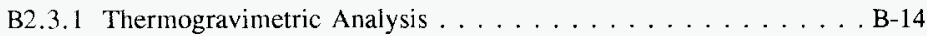

B2.3.2 Differential Scanning Calorimetry . . . . . . . . . B-15

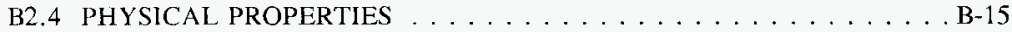

B2.4.1 Density and Percent Solids . . . . . . . . . . B-15

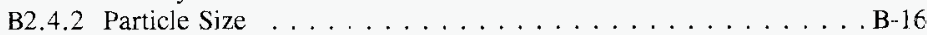

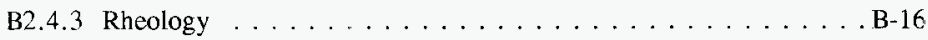

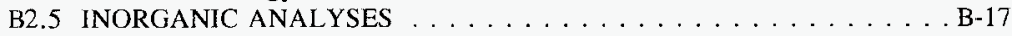

B2.5.1 Inductively Coupled Plasma . . . . . . . . . . . . B-17

B2.5.2 Ion Chromatography . . . . . . . . . . . . B-17

B2.5.3 Total Uranium . . . . . . . . . . . . . . . . B-18

B2.5.4 Arsenic Selenium, and Mercury by Atomic

Absorption Spectroscopy . . . . . . . . . . . . . . . B-18

B2.5.5 Ammonia . . . . . . . . . . . . . . . B-18

B2.5.6 Cyanide by Distillation and Spectroscopy . . . . . . . . . . B-18

B2.5.7 Nitrite by Spectrophotometry . . . . . . . . . . . B-18

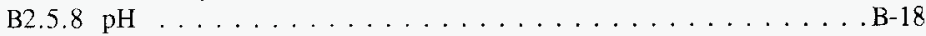

B2.6 ORGANIC ANALYSES . . . . . . . . . . . . . . . B-19

B2.6.1 Semivolatile and Volatile Organic Analysis . . . . . . . . . . B-19

B2.7 TOTAL INORGANIC AND ORGANIC CARBON . . . . . . . . . . . B-19

B2.8 RADIONUCLIDES ... . . . . . . . . . . . . . . . . . . B-19

B2.8.1 Fission Products by Gamma Energy Analysis . . . . . . . . . . B-19

B2.8.2 Fission Products by Separation and Counting . . . . . . . . . B-19

B2.8.3 Total Beta Activities by Proportional Counting . . . . . . . B-20

B2.8.4 Transuranic Radionuclides by Separation and Counting . . . . . B-20

B2.9 VAPOR PHASE MEASUREMENT . . . . . . . . . . . . . . . . . . . . . . . . . .

B2.10 HISTORICAL SAMPLING RESULTS . . . . . . . . . . . . . B-20

B2.11 ANALYTICAL DATA TABLES ..................... 


\section{CONTENTS (Continued)}

B3.0 ASSESSMENT OF CHARACTERIZATION RESULTS . . . . . . . . . . B-93

B3.1 FIELD OBSERVATIONS . . . . . . . . . . . . . . B-93

B3.2 QUALITY CONTROL ASSESSMENT . . . . . . . . . . . B-93

B3.3 DATA CONSISTENCY CHECKS . . . . . . . . . . . . . . B-94

B3.3.1 Comparison of Results from Different

Analytical Methods . . . . . . . . . . . . . . . . B-94

B3.3.2 Mass and Charge Balance . . . . . . . . . . . . B-96

B3.4 CALCULATION OF ANALYTICAL BASED MEANS

AND INVENTORY . . . . . . . . . . . . . . . . B-98

B4.0 APPENDIX B REFERENCES . . . . . . . . . . . . . . B-106

APPENDIX C: STATISTICAL ANALYSIS FOR ISSUE RESOLUTION $\ldots \ldots \ldots$ C-1

C1.0 STATISTICS FOR SAFETY SCREENING DQO $\ldots \ldots \ldots \ldots \ldots$

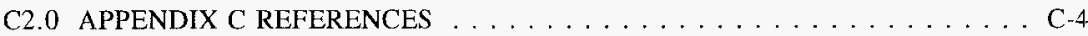

APPENDIX D: EVALUATION TO ESTABLISH BEST-BASIS INVENTORY

FOR TANK $241-\mathrm{T}-104 \ldots \ldots \ldots \ldots \ldots \ldots \ldots$ D-1

D1.0 CHEMICAL INFORMATION SOURCES $\ldots \ldots \ldots \ldots \ldots \ldots \ldots \ldots$

D2.0 COMPARISON OF COMPONENT INVENTORY VALUES $\ldots \ldots \ldots \ldots$ D-6

D3.0 REVIEW AND EVALUATION OF COMPONENT INVENTORIES $\ldots \ldots \ldots$ D-6 D3.1 PROCESS KNOWLEDGE . . . . . . . . . . . . . D-6

D3.2 HISTORICAL ESTIMATION OF THE CONTENTS

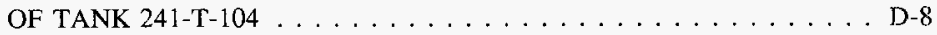

D3.3 PROCESS HISTORY ESTIMATION $\ldots \ldots \ldots \ldots \ldots \ldots \ldots$ D-8

D3.4 CONTRIBUTING WASTE TYPES $\ldots \ldots \ldots \ldots \ldots \ldots \ldots$ D-8

D3.5 TECHNICAL FLOWSHEET INFORMATION $\ldots \ldots \ldots \ldots \ldots$ D-8

D3.6 EVALUATION OF COMPONENT INVENTORIES . . . . . . . . D-9

D3.6.1 Solids Concentration Factor and Partition Factors

for First Cycle Bismuth Phosphate Waste

in Tank 241-T-104 . . . . . . . . . . . . . . . D-10

D3.6.2 Inventory of Components Assumed to Precipitate 100 Percent . D-12 


\section{CONTENTS (Continued)}

D4.0 DEFINE THE BEST-BASIS AND ESTABLISH COMPONENT INVENTORIES D-16 D5.0 APPENDIX D REFERENCES . . . . . . . . . . . . . . . . . . D-19

APPENDIX E: BIBLIOGRAPHY FOR TANK 241-T-104 . . . . . . . . . . . . E-1

\section{LIST OF FIGURES}

A2-1. Riser Configuration for Tank $241-\mathrm{T}-104 \ldots \ldots \ldots \ldots \ldots$. . . . . . . .

A2-2. Tank Cross-Section $\ldots \ldots \ldots \ldots \ldots \ldots \ldots \ldots \ldots \ldots$

A3-1. Tank Layer Model . . . . . . . . . . . . . . . . . A-11

A4-1. Tank 241-T-104 Level History . . . . . . . . . . . . . . . . A-16

A4-2. Tank 241-T-104 High Temperature Plot . . . . . . . . . . . . . . . A-17

\section{LIST OF TABLES}

1-1. Summary of Recent Sampling . . . . . . . . . . . . . . . . 1-2

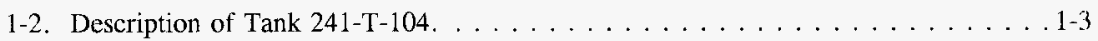

2-1. Tank 241-T-104 Projected Heat Load ... . . . . . . . . . . . 2-3

2-2. Summary of Screening Evaluation Results . . . . . . . . . . . 2-3

3-1. Best-Basis Inventory Estimates for Nonradioactive Components

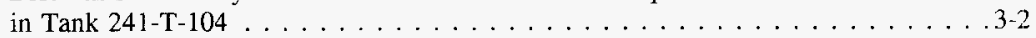

3-2. Best-Basis Inventory Estimates for Radioactive Components

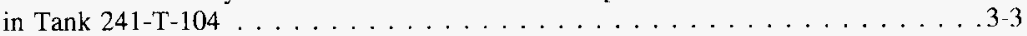

4-1. Acceptance of Tank 241-T-104 Sampling and Analysis . . . . . . . . . . . 4-1 


\section{LIST OF TABLES (Continued)}

4-2. Acceptance of Evaluation of Characterization Data

and Information for Tank $241-\mathrm{T}-104 \ldots \ldots \ldots$. . . . . . . . . . . 4-2

A1-1. Tank 241-T-104 Contents Status Summary $\ldots \ldots \ldots \ldots \ldots \ldots$ A-4

A2-1. Tank 241-T-104 Risers . . . . . . . . . . . . . . A-8

A3-1. Tank 241-T-104 Major Transfers . . . . . . . . . . . . . . . . . . . . A A-9

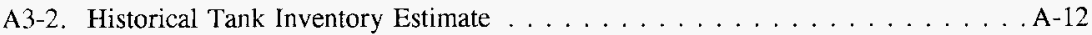

B1-1. Integrated Data Quality Objective Requirements for Tank 241-T-104 . . . . . B-4

B1-2. Tank 241-T-104 Sample Description. . . . . . . . . . . . . . . B-6

B1-3. Tank 241-T-104 Sample Analysis Summary . . . . . . . . . . . . B-10

B2-1. Analytical Presentation Tables . . . . . . . . . . . B-14

B2-2. Tank 241-T-104 Analytical Results: Total Alpha (Alpha) . . . . . . . . . . B-23

B2-3. Percent Water by TGA and Gravimetric Analysis. . . . . . . . . . B-24

B2-4. Tank 241-T-104 Core 45 Physical Measurements . . . . . . . . . . B-28

B2-5. Tank 241-T-104 Analytical Results: Density (Physical Properties) . . . . . . . B B-28

B2-6. Tank 241-T-104 Particle Size Data . . . . . . . . . . . . . . B-30

B2-7. Shear Strength Results . . . . . . . . . . . . . . . B-30

B2-8. Tank 241-T-104 Analytical Results: Aluminum (ICP) $\ldots \ldots \ldots \ldots \ldots$. . . . . .

B2-9. Tank 241-T-104 Analytical Results: Antimony (ICP) . . . . . . . . . . . B-32

B2-10. Tank 241-T-104 Analytical Results: Arsenic (ICP) $\ldots \ldots \ldots \ldots \ldots \ldots$. . . . . . .

B2-11. Tank 241-T-104 Analytical Results: Barium (ICP) . . . . . . . . . . B-34

B2-12. Tank 241-T-104 Analytical Results: Beryllium (ICP) . . . . . . . . . B-35 


\section{LIST OF TABLES (Continued)}

B2-13. Tank 241-T-104 Analytical Results: Bismuth (ICP) . . . . . . . . . . B B-36

B2-14. Tank 241-T-104 Analytical Results: Boron (ICP) . . . . . . . . . . . B-37

B2-15. Tank 241-T-104 Analytical Results: Cadmium (ICP) . . . . . . . . . . B-38

B2-16. Tank 241-T-104 Analytical Results: Calcium (ICP) . . . . . . . . . . . . . B-39

B2-17. Tank 241-T-104 Analytical Results: Cerium (ICP) . . . . . . . . . B-40

B2-18. Tank 241-T-104 Analytical Results: Chromium (ICP) $\ldots \ldots \ldots \ldots \ldots$. . . . .

B2-19. Tank 241-T-104 Analytical Results: Cobalt (ICP) $\ldots \ldots \ldots \ldots \ldots \ldots$. . . . . .

B2-20. Tank 241-T-104 Analytical Results: Copper (ICP) $\ldots \ldots \ldots \ldots \ldots \ldots$. . . .43

B2-21. Tank 241-T-104 Analytical Results: Iron (ICP) $\ldots \ldots \ldots \ldots \ldots \ldots \ldots$ B-44

B2-22. Tank 241-T-104 Analytical Results: Lanthanum (ICP) . . . . . . . . . B B-45

B2-23. Tank 241-T-104 Analytical Results: Lead (ICP) $\ldots \ldots \ldots \ldots \ldots \ldots$. . . . . . .

B2-24. Tank 241-T-104 Analytical Results: Magnesium (ICP) . . . . . . . . . B-47

B2-25. Tank 241-T-104 Analytical Results: Manganese (ICP) . . . . . . . . . . B-48

B2-26. Tank 241-T-104 Analytical Results: Nickel (ICP) . . . . . . . . . . . . B-49

B2-27. Tank 241-T-104 Analytical Results: Phosphorus (ICP) . . . . . . . . . B-50

B2-28. Tank 241-T-104 Analytical Results: Potassium (ICP) $\ldots \ldots \ldots \ldots \ldots \ldots$. . . . .

B2-29. Tank 241-T-104 Analytical Results: Selenium (ICP) $\ldots \ldots \ldots \ldots \ldots \ldots$ B-52

B2-30. Tank 241-T-104 Analytical Results: Silicon (ICP) . . . . . . . . . . . B-53

B2-31. Tank 241-T-104 Analytical Results: Silver (ICP) . . . . . . . . . . B-54

B2-32. Tank 241-T-104 Analytical Results: Sodium (ICP) . . . . . . . . . B-55

B2-33. Tank 241-T-104 Analytical Results: Strontium (ICP) . . . . . . . . . . B-56 


\section{LIST OF TABLES (Continued)}

B2-34. Tank 241-T-104 Analytical Results: Sulfur (ICP) $\ldots \ldots \ldots \ldots$. . . . B-57 B2-35. Tank 241-T-104 Analytical Results: Tin (ICP) . . . . . . . . . . . B-58

B2-36. Tank 241-T-104 Analytical Results: Titanium (ICP) $\ldots \ldots \ldots \ldots \ldots$. . . . . .59

B2-37. Tank 241-T-104 Analytical Results: Zinc (ICP) $\ldots \ldots \ldots \ldots \ldots \ldots$. . . . . . . .

B2-38. Tank 241-T-104 Analytical Results: Zirconium (ICP) $\ldots \ldots \ldots \ldots \ldots$. . . . . .

B2-39. Tank 241-T-104 Analytical Results: Chloride (IC) . . . . . . . . . . . . B-62

B2-40. Tank 241-T-104 Analytical Results: Fluoride (IC) . . . . . . . . . . B-62

B2-41. Tank 241-T-104 Analytical Results: Nitrate (IC) . . . . . . . . . . . B-63

B2-42. Tank 241-T-104 Analytical Results: Nitrite (IC) . . . . . . . . . . . . . B-63

B2-43. Tank 241-T-104 Analytical Results: Phosphate (IC) . . . . . . . . . . . B-64

B2-44. Tank 241-T-104 Analytical Results: Sulfate (IC) . . . . . . . . . . . . . B-64

B2-45. Tank 241-T-104 Analytical Results: Total Uranium (LF) . . . . . . . . . B-65

B2-46. Tank 241-T-104 Analytical Results: Arsenic (AA [As]) . . . . . . . . . . B-65

B2-47. Tank 241-T-104 Analytical Results: Selenium (AA [Se]) . . . . . . . . B B-66

B2-48. Tank 241-T-104 Analytical Results: Mercury (CVAA [Hg]) . . . . . . . B-66

B2-49. Tank 241-T-104 Analytical Results: Ammonia (Distillation) . . . . . . . . . B-67

B2-50. Tank 241-T-104 Analytical Results: Cyanide (Spec [CN]) . . . . . . . . . B-67

B2-51. Tank 241-T-104 Analytical Results: Nitrite (Spectrophotometric) . . . . . . . B-68 B2-52. Tank 241-T-104 Analytical Results: $\mathrm{pH}$ Measurement $(\mathrm{pH}) \ldots \ldots \ldots \ldots$. . . . . .

B2-53. Tank 241-T-104 Analytical Results: Bis(2-ethylhexyl) phthalate (SVOA) . . . B-69 B2-54. Tank 241-T-104 Analytical Results: Dodecane (SVOA) . . . . . . . . . B-69 


\section{LIST OF TABLES (Continued)}

B2-55. Tank 241-T-104 Analytical Results: Pentadecane (SVOA) . . . . . . . . . . . B-69

B2-56. Tank 241-T-104 Analytical Results: Tetradecane (SVOA) . . . . . . . . . . B-70

B2-57. Tank 241-T-104 Analytical Results: Tridecane (SVOA) . . . . . . . . . B-70

B2-58. Tank 241-T-104 Analytical Results: Non-Detected SVOA Analytes. . . . . . . B-71

B2-59. Tank 241-T-104 Analytical Results: Acetone (VOA) . . . . . . . . . . B-72

B2-60. Tank 241-T-104 Analytical Results: Hexamethyl Disiloxane (VOA) . . . . . B-73

B2-61. Tank 241-T-104 Analytical Results: Methoxytrimethyl Silane (VOA) . . . . B-73

B2-62. Tank 241-T-104 Analytical Results: Methylenechloride (VOA) . . . . . . . B-74

B2-63. Tank 241-T-104 Analytical Results: Toluene (VOA) . . . . . . . . . . . B-75

B2-64. Tank 241-T-104 Analytical Results: Trimethyl Silanol (VOA) . . . . . . . B-76

B2-65. Tank 241-T-104 Analytical Results: Non-Detected VOA Analytes . . . . . . B B-77

B2-66. Tank 241-T-104 Analytical Results: Carbonate (TIC) . . . . . . . . . . . B-78

B2-67. Tank 241-T-104 Analytical Results: Total Organic Carbon

(Furnace Oxidation) . . . . . . . . . . . . . . B $\ldots \ldots$

B2-68. Tank 241-T-104 Analytical Results: Americium-241 (GEA) . . . . . . . . . B-79

B2-69. Tank 241-T-104 Analytical Results: Cesium-137 (GEA) . . . . . . . . . . B-79

B2-70. Tank 241-T-104 Analytical Results: Cobalt-60 (GEA) . . . . . . . . . . B-80

B2-71. Tank 241-T-104 Analytical Results: Europium-154 (GEA) . . . . . . . . . B-80

B2-72. Tank 241-T-104 Analytical Results: Europium-155 (GEA) . . . . . . . . . . B-81

B2-73. Tank 241-T-104 Analytical Results: Iodine-129 (I129) . . . . . . . . . . . B-81

B2-74. Tank 241-T-104 Analytical Results: Carbon-14 (C14) . . . . . . . . . . B-82 


\section{LIST OF TABLES (Continued)}

B2-75. Tank 241-T-104 Analytical Results: Tritium (Liq. Scin.) . . . . . . . . . . . B-82 B2-76. Tank 241-T-104 Analytical Results: Selenium-79 (Se79) . . . . . . . . . . . B-82 B2-77. Tank 241-T-104 Analytical Results: Technetium-99 (Te) . . . . . . . . . . . B-83 B2-78. Tank 241-T-104 Analytical Results: Strontium-90 (Sr) . . . . . . . . . . . B-83 B2-79. Tank 241-T-104 Analytical Results: Total Beta . . . . . . . . . . . . . . B-84 B2-80. Tank 241-T-104 Analytical Results: Americium-241 (Alpha Spec) . . . . . . . B-84 B2-81. Tank 241-T-104 Analytical Results: Plutonium-238 (Alpha Spec) . . . . . . B-85 B2-82. Tank 241-T-104 Analytical Results: Plutonium-239/240 (Alpha Spec) . . . . B-8.5 B2-83. Tank 241-T-104 Analytical Results: Neptunium-237 (Np237) . . . . . . . . B-86 B2-84. Tank 241-T-104 Analytical Results: Pu238 to Pu ratio (Mass Spec.) . . . . . B-86 B2-85. Tank 241-T-104 Analytical Results: Pu239 to Pu ratio (Mass Spec.) . . . . B-87 B2-86. Tank 241-T-104 Analytical Results: Pu240 to Pu ratio (Mass Spec.) . . . . . B-87 B2-87. Tank 241-T-104 Analytical Results: Pu241 to Pu ratio (Mass Spec.) . . . . . B-88 B2-88. Tank 241-T-104 Analytical Results: Pu242 to Pu ratio (Mass Spec.) . . . . . B-88 B2-89. Tank 241-T-104 Analytical Results: U234 to U ratio (Mass Spec.) . . . . . B-89 B2-90. Tank 241-T-104 Analytical Results: U235 to U ratio (Mass Spec.) . . . . . . B-89 B2-91. Tank 241-T-104 Analytical Results: U236 to U ratio (Mass Spec.) . . . . . B-90 B2-92. Tank 241-T-104 Analytical Results: U238 to U ratio (Mass Spec.) . . . . . . B-90 B2-93. 1996 Evaluation of Tank Headspace Flammability . . . . . . . . . . . . . B-91

B2-94. Physical Properties of 1979 Core Sample. . . . . . . . . . . . . . . . . . . . B-91 B2-95. Chemical Characteristics of Composite of 1979 Core Sample . . . . . . . . B-92 


\section{LIST OF TABLES (Continued)}

B3-1. Total Alpha Comparison $\ldots \ldots \ldots \ldots \ldots \ldots \ldots \ldots$. . . . . . . . . . . . .

B3-2. Total Beta Comparison . . . . . . . . . . . . . B-96

B3-3. Cation Mass and Charge Data. . . . . . . . . . . . . . . . . . . . . B-97

B3-4. Anion Mass and Charge Data . . . . . . . . . . . . . . . B-98

B3-5. Mass Balance Totals. . . . . . . . . . . . . . . . . . . B-98

B3-6. Tank Concentration From Composite Samples. . . . . . . . . . . . . . . . . . B-99

B3-7. Tank 241-T-104 Core Recoveries. . . . . . . . . . . . . . . . . . . B-104

C1-1. One-Sided 95 Percent Confidence Interval Upper Limits for Total Alpha for Tank $241-\mathrm{T}-104 \ldots \ldots \ldots \ldots \ldots \ldots$. . . . . . . . .

D2-1. Sample- and Historical Tank Content-Based Inventory Estimates for Nonradioactive Components $\ldots \ldots \ldots \ldots \ldots \ldots \ldots \ldots \ldots$

D2-2. Sample- and Historical Tank Content-Based Inventory Estimates for Radioactive Components . . . . . . . . . . . . . . . . . D-5

D3-1. Estimated Total Volume of Waste Types Received By Tank 241-T-104 . . . D D-7

D3-2. Technical Flowsheet and Los Alamos National Laboratory Defined Waste Streams (Hanford Defined Waste Model) $\ldots . . \ldots$. . . D-9

D3-3. Comparison of Selected Component Inventory Estimates for Tank 241-T-104 Waste . . . . . . . . . . . . . . . . . D-13

D3-4. Comparisons Based on Fuel Production . . . . . . . . . . . . . D-14

D4-1. Best-Basis Inventory Estimates for Nonradioactive Components in Tank 241-T-104 . . . . . . . . . . . . . . . . . D-17

D4-2. Best-Basis Inventory Estimates for Radioactive Components

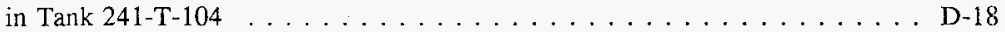




\section{LIST OF TERMS}

$1 \mathrm{Cl}$

$1 \mathrm{C} 2$

$\mu \mathrm{Ci} / \mathrm{g}$

$\mu \mathrm{eq} / \mathrm{g}$

$\mu \mathrm{g} / \mathrm{g}$

$\mu \mathrm{g} / \mathrm{mL}$

$\mu \mathrm{m}$

AA

ANOVA

ASTM

BDL

$\mathrm{Btu} / \mathrm{hr}$

CF

$\mathrm{Ci}$

$\mathrm{Ci} / \mathrm{L}$

CI

$\mathrm{cm}$

$\mathrm{CW}$

CVAA

DL

DOE

DQO

DSC

dynes $/ \mathrm{cm}^{2}$

Ecology

$\mathrm{ft}$

GEA

GHAA

$\mathrm{g}$

$\mathrm{g} / \mathrm{L}$

$\mathrm{g} / \mathrm{mL}$

HDW

HTCE

IC

ICP

ID

in.

$\mathrm{J} / \mathrm{g}$

$\mathrm{kg}$ first cycle decontamination waste 1944-1949

first cycle decontamination waste 1950-1956

microcuries per gram

microequivalents per gram

micrograms per gram

micrograms per milliliter

micrometers

atomic absorption

analysis of variance

American Society for Testing and Materials

below detection limit

British thermal units per hour

concentration factor

curies

curies per liter

confidence interval

centimeters

cladding waste

cold vapor atomic absorption

drainable liquid

U.S. Department of Energy

data quality objectives

differential scanning calorimetry

dynes per square centimeter

Washington State Department of Ecology

feet

gamma energy analysis

gaseous hydride atomic absorption

grams

grams per liter

grams per milliliter

Hanford defined waste

historical tank content estimate

ion chromatography

inductively coupled plasma

incomplete data

inches

joules per gram

kilograms 


\section{LIST OF TERMS (Continued)}

$\begin{array}{ll}\mathrm{kg} / \mathrm{L} & \text { kilograms per liter } \\ \mathrm{kgal} & \text { kilogallons } \\ \mathrm{kL} & \text { kiloliters } \\ \mathrm{LFL} & \text { lower flammability limit } \\ \mathrm{LL} & \text { lower limit } \\ \mathrm{LF} & \text { laser fluorimetry } \\ \mathrm{m} & \text { meter } \\ \mathrm{M} & \text { moles per liter } \\ \mathrm{mL} & \text { milliiters } \\ \mathrm{mm} & \text { millimeters } \\ \text { MT } & \text { metric tons } \\ \text { MTU } & \text { metric tons of uranium } \\ \text { n/a } & \text { not applicable } \\ \text { NA } & \text { not analyzed } \\ \text { n/d } & \text { not decided } \\ \text { NPH } & \text { normal paraffin hydrocarbon } \\ \text { n/r } & \text { not reviewed } \\ \text { NR } & \text { not reported } \\ \text { PF } & \text { partitioning factor } \\ \text { PHMC } & \text { Project Hanford Management Contractor } \\ \text { PNNL } & \text { Pacific Northwest National Laboratory } \\ \text { ppmv } & \text { parts per million volume } \\ \text { Pa } & \text { pascals } \\ \text { QC } & \text { quality control } \\ \text { REML } & \text { restricted maximum likelihood estimation } \\ \text { RPD } & \text { relative percent difference } \\ \text { SU } & \text { supernatant } \\ \text { SVOA } & \text { semivolatile organic analysis } \\ \text { SWLIQ } & \text { saltwell liquid waste } \\ \text { TCLP } & \text { toxic characteristic leach procedure } \\ \text { TCR } & \text { tank characterization report } \\ \text { TGA } & \text { thermogravimetric analysis } \\ \text { TIC } & \text { total inorganic carbon } \\ \text { TLM } & \text { tank layer model } \\ \text { TOC } & \text { total organic carbon } \\ \text { TWRS } & \text { Tank Waste Remediation System } \\ \text { UL } & \text { upper limit } \\ \text { VOA } & \text { volatile organic analysis } \\ \text { W } & \text { watts } \\ \text { WSTRS } & \text { waste status and transaction record summary } \\ \text { Wt\% } & \text { weight percent } \\ & \\ & \end{array}$




\subsection{INTRODUCTION}

One of the major functions of the Tank Waste Remediation System (TWRS) is to characterize wastes in support of waste management and disposal activities at the Hanford Site. Analytical data from sampling and analysis, along with other available information about a tank, are compiled and maintained in a tank characterization report (TCR). This report and its appendices serve as the TCR for single-shell tank 241-T-104. The objectives of this report are: 1) to use characterization data in response to technical issues associated with 241-T-104 waste; and 2) to provide a standard characterization of this waste in terms of a best-basis inventory estimate. The response to technical issues is summarized in Section 2.0, and the best-basis inventory estimate is presented in Section 3.0. Recommendations regarding safety status and additional sampling needs are provided in Section 4.0. Supporting data and information are contained in the appendices. This report also supports the requirements of the Hanford Federal Facility Agreement and Consent Order (Ecology et al. 1996) milestone M-44-05.

\subsection{SCOPE}

Characterization information presented in this report originated from sample analyses and known existing (historical) sources. While the data quality objectives (DQOs) required that technical issues be resolved using results from recent sampling events (listed in Table 1-1), other information could be used to support (or challenge) conclusions derived from these results. Historical information for tank 241-T-104, provided in Appendix A, included surveillance information, records pertaining to waste transfers and tank operations, and expected tank contents derived from a process knowledge model.

The results from the recent sampling events listed in Table 1-1, as well as sample data obtained prior to 1989, are summarized in Appendix B. The results of the 1992 sampling events, also reported in the laboratory data package (Pool 1994), satisfied the data requirements specified in the waste characterization plan for this tank (Hill et al. 1991). The statistical analysis and numerical manipulation of data used in issue resolution are reported in Appendix C. Appendix D contains the evaluation to establish the best basis for the inventory estimate and the statistical analysis performed for this evaluation. A bibliography that resulted from an in-depth literature search of all known information sources applicable to tank 241-T-104 and its respective waste types is contained in Appendix E. The reports listed in Appendix $\mathrm{E}$ may be found in the Tank Characterization Resource Center. 
Table 1-1. Summary of Recent Sampling

\begin{tabular}{|c|c|c|c|c|c|}
\hline Sanplet Date & Hinse & 30911100 & Segrinomition & $\begin{array}{l}\text { perocht: } \\
\operatorname{locher}\end{array}$ & Wgs \\
\hline \multirow{2}{*}{$\begin{array}{l}\text { Core sample } \\
\text { August } 1992\end{array}$} & \multirow[t]{2}{*}{ Solid } & Riser 3 & \multirow{2}{*}{$\begin{array}{l}\text { None. Core } \\
\text { composites and } \\
\text { some segments } \\
\text { analyzed }\end{array}$} & 81 & 1,408 \\
\hline & & Riser 6 & & 79 & 1,410 \\
\hline $\begin{array}{l}\text { Vapor sample } \\
\text { February } 1996\end{array}$ & Gas & $\begin{array}{l}\text { Riser } 8, \operatorname{tank} \\
\text { headspace }\end{array}$ & $n / a$ & $\mathrm{n} / \mathrm{a}$ & $n / a$ \\
\hline
\end{tabular}

Note:

$\mathbf{n} / \mathbf{a}=$ not applicable

\subsection{TANK BACKGROUND}

Tank 241-T-104 is located in the 200 West Area T Tank Farm on the Hanford Site. It is the first tank in a three-tank cascade series. The tank went into service in March 1946, receiving first cycle decontamination waste from bismuth phosphate fuel separation operations at T Plant. Cascading began in the second quarter of 1948. With the exception of several transfers of supernatant to other single-shell tanks (241-TX-118, -TY-103, and -T-101) and double-shell tank 241-AW-102, the entire tank history consisted of receipt and cascade of first-cycle decontamination waste (1C1 - produced from 1944 until 1949, and 1C2 - produced from 1950 until 1956) from T Plant bismuth phosphate operations. The tank was removed from service in 1976 , primary stabilized in 1978 , and partially isolated in 1982. Pumping of supernatant to support stabilization began in March 1996, and as of September $30,1996,317 \mathrm{~kL}(83.8 \mathrm{kgal})$ of supernatant had been removed from the tank (Hanlon 1996).

A description of tank 241-T-104 is summarized in Table 1-2. The tank has an operating capacity of $2,010 \mathrm{~kL}(530 \mathrm{kgal})$, and presently contains an estimated $1,408 \mathrm{~kL}(372 \mathrm{kgal})$ of non-complexed waste (Hanlon 1996). The tank is not on the Watch List (Public Law $101-510)$. 
HNF-SD-WM-ER-372 Rev. 1

Table 1-2. Description of Tank 241-T-104.

\begin{tabular}{|c|c|}
\hline$\sqrt{1}+4$ & ANA BESORPIOK \\
\hline Type & Single-shell \\
\hline Constructed & $1943-1944$ \\
\hline In-service & March 1946 \\
\hline Diameter & $22.9 \mathrm{~m}(75.0 \mathrm{ft})$ \\
\hline Operating depth & $5.2 \mathrm{~m}(17 \mathrm{ft})$ \\
\hline Capacity & $2,010 \mathrm{~kL}(530 \mathrm{kgal})$ \\
\hline Bottom Shape & Dish \\
\hline Ventilation & Passive \\
\hline $4.4 \% 4.4 \%$ & TANK SIATUS \\
\hline Waste classification & Non-complexed \\
\hline Total waste volume & $1,408 \mathrm{~kL}(372 \mathrm{kgal})$ \\
\hline Supernatant volume & $0 \mathrm{~kL}(0 \mathrm{kgal})$ \\
\hline Saltcake volume & $0 \mathrm{~kL}(0 \mathrm{kgal})$ \\
\hline Sludge volume & $1,408 \mathrm{~kL}(372 \mathrm{kgal})$ \\
\hline Drainable interstitial liquid volume & $182 \mathrm{~kL}(48 \mathrm{kgal})$ \\
\hline 4 & TANK STAYGS \\
\hline Waste surface level $(10 / 2 / 96)$ & $351.8 \mathrm{~cm}(138.5 \mathrm{in})$. \\
\hline Temperature (2/77 to $11 / 96)$ & $11.5^{\circ} \mathrm{C}\left(52.7^{\circ} \mathrm{F}\right)$ to $25.6^{\circ} \mathrm{C}\left(78^{\circ} \mathrm{F}\right)$ \\
\hline Integrity & Sound \\
\hline Watch List & None \\
\hline & SAMPI MV DATH \\
\hline Core samples & August 1992 \\
\hline$\sqrt{8}$ & SER YIC \\
\hline Declared inactive & Second quarter 1976 \\
\hline Primary stabilization & 1978 \\
\hline Partially isolated & 1982 \\
\hline Stabilization & Began March 1996 , currently in progress \\
\hline
\end{tabular}

Note:

'Waste volume is estimated from surface-level measurements. 
HNF-SD-WM-ER-372 Rev. 1

This page intentionally left blank. 


\subsection{RESPONSE TO TECHNICAL ISSUES}

The following technical issue has been identified for tank 241-T-104 (Brown et al. 1996).

- Does the waste pose or contribute to any recognized potential safety problems?

The waste characterization plan (Hill et al. 1991) provides the types of sampling and analysis used to address the first of these issues. Data from the analysis of the 1992 core samples and tank headspace flammability measurements conducted in 1996, as well as available historical information, provided the means to respond to this issue. This response is detailed in the following sections. See Appendix B for sample and analysis data for tank 241-T-104.

In addition to the technical issue related to the safety of the tank, Brown et al. (1996) identifies the need to provide sample material from this tank to perform sludge washing studies in support of waste pretreatment.

\subsection{SAFETY SCREENING}

The data needed to screen the waste in tank 241-T-104 for potential safety problems are documented in Tank Safety Screening Data Quality Objective (Dukelow et al. 1995). These potential safety problems are: exothermic conditions in the waste; flammable gases in the waste and/or tank headspace; and criticality conditions in the waste. Each of these conditions is addressed separately below. Because tank 241-T-104 is not a Watch List tank, the safety screening DQO was the only safety-related DQO associated with the sampling effort. Tank 241-T-104 was sampled in 1992, prior to the existence of the safety screening DQO. However, data from the analyses may be used to fulfill the requirements of the DQO.

\subsubsection{Exothermic Conditions (Energetics)}

The first requirement outlined in the safety screening $\mathrm{DQO}$ is to ensure that there are not sufficient exothermic constituents (organic or ferrocyanide) in tank 241-T-104 to present a safety hazard. Although the safety screening DQO required that the waste sample profile be tested for energetics every $24 \mathrm{~cm}$ (9.5 in.) to determine if the energetics exceed the safety threshold limit, differential scanning calorimetry (DSC) analyses were performed on whole segments and composites. The threshold limit for energetics is $480 \mathrm{~J} / \mathrm{g}$ on a dry weight basis. Results obtained using DSC indicated that no exotherms were apparent for any of the samples from cores 45 and 46 (Pool 1994). 
Historically, there is no evidence that any exothermic agent should exist in this waste. Waste transfer records indicate that the major waste type expected to be in the tank is $1 \mathrm{C} 1$ and $1 \mathrm{C} 2$ sludge from the bismuth phosphate process (Agnew et al. 1996a). Neither of these waste types is expected to have organic or ferrocyanide constituents.

\subsubsection{Flammable Gas}

Vapor phase measurements were not taken when cores 45 and 46 were obtained, but were taken in the tank headspace in February 1996 in support of a riser preparation procedure (WHC 1996). No flammable gas was detected (0 percent of the lower flammability limit [LFL]). Data from these vapor phase measurements are presented in Appendix B.

\subsubsection{Criticality}

The safety threshold limit for criticality is $1 \mathrm{~g}{ }^{239} \mathrm{Pu}$ per liter of waste. Assuming that all total alpha activity is from ${ }^{239} \mathrm{Pu}$ and using a measured density of $1.29 \mathrm{~g} / \mathrm{mL}, 1 \mathrm{~g} / \mathrm{L}$ of ${ }^{239} \mathrm{Pu}$ is equivalent to $47.7 \mu \mathrm{Ci} / \mathrm{g}$ of total alpha activity. Waste samples were tested for total alpha activity for both composite samples from both cores. Concentrations in all samples were well below this limit. Additionally, as required by the DQO, the upper limit of the one-sided 95 percent confidence interval (CI) for these results was less than $1 \mathrm{~g} / \mathrm{L}$; therefore, criticality is not an issue for this tank. The method used to calculate confidence intervals is contained in Appendix C.

\subsection{OTHER TECHNICAL ISSUES}

A factor in assessing tank safety is the heat generation and temperature of the waste. Heat is generated in the tanks from radioactive decay. An estimate of the tank heat load based on the 1992 sample event (Pool 1994) was $50.2 \mathrm{~W}(171 \mathrm{Btu} / \mathrm{hr}$ ). The heat load estimate based on the tank process history was $185 \mathrm{~W}(631 \mathrm{Btu} / \mathrm{hr})$ (Agnew et al. 1996b). The heat load estimate based on the tank headspace temperature was $950 \mathrm{~W}(3,240 \mathrm{Btu} / \mathrm{hr})(\mathrm{Kummerer}$ 1995). All of these estimates are quite low, and are well below the limit of $11,700 \mathrm{~W}$ $(40,000 \mathrm{Btu} / \mathrm{hr})$ that separates high- and low-heat-load tanks (Smith 1986.) The major contributors to the tank heat load are listed in Table 2-1. Radionuclides were chosen for the heat load calculation based on measurement above the detection limit and for contribution to the heat load greater than $0.001 \mathrm{~W}$.

Sludge samples from the tank 241-T-104 core samples were provided to the pretreatment program. Wash and leach factors for this and other tanks were determined and will be incorporated into the TWRS Technical Baseline, where wash factors will be used to estimate partitioning of the SST inventory into soluble and insoluble portions, and the leach factor will be used to estimate further removal of some analytes (Colton 1996). 


\subsection{SUMMARY}

The results from all tank waste sample analyses performed to address tank safety screening issues showed that no primary analyte exceeded any of the safety decision threshold limits. Tank vapor sampling indicated no flammability concerns with the tank vapors. The results of the analyses are summarized in Table 2-2.

Table 2-1. Tank 241-T-104 Projected Heat Load. ${ }^{1}$

\begin{tabular}{|c|c|c|c|}
\hline 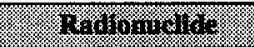 & 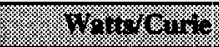 & soryes & W 1016 \\
\hline${ }^{241} \mathrm{Am}$ & 0.0328 & 30.5 & 1.03 \\
\hline${ }^{137} \mathrm{Cs}$ & 0.00472 & 428 & 2.02 \\
\hline${ }^{155} \mathrm{Eu}$ & 0.00248 & 7.35 & 0.0182 \\
\hline${ }^{239} \mathrm{Pu}$ & 0.0305 & 269 & 8.20 \\
\hline${ }^{240} \mathrm{Pu}$ & 0.0306 & 32.5 & 0.995 \\
\hline${ }^{90} \mathrm{Sr}$ & 0.00670 & 5,650 & 37.9 \\
\hline \multicolumn{3}{|l|}{ Total watts } & 50.2 \\
\hline
\end{tabular}

Note:

${ }^{1}$ Pool (1994)

Table 2-2. Summary of Screening Evaluation Results.

\begin{tabular}{|l|l|l|}
\hline \multicolumn{1}{|c|}{ I loue } & \multicolumn{1}{|c|}{ Sub } & \multicolumn{1}{|c|}{} \\
\hline \multirow{3}{*}{$\begin{array}{l}\text { Safety } \\
\text { screening }\end{array}$} & Energetics & No exotherms observed in any sample. \\
\cline { 2 - 3 } & Flammable gas & $\begin{array}{l}1996 \text { vapor measurement reported 0 percent of LFL } \\
\text { (combustible gas meter). }\end{array}$ \\
\cline { 2 - 3 } Criticality & $\begin{array}{l}\text { All analytical results and confidence interval limits } \\
\text { were well below } 47.7 \mu \text { Ci/g total alpha (within } \\
95 \text { percent confidence interval on each sample). }\end{array}$ \\
\hline
\end{tabular}


HNF-SD-WM-ER-372 Rev. 1

This page left blank intentionally. 


\subsection{BEST-BASIS INVENTORY ESTIMATE}

Information about chemical, radiological, and/or physical properties is used to perform safety analyses, engineering evaluations, and risk assessment associated with waste management activities, as well as regulatory issues. These activities include overseeing tank farm operations and identifying, monitoring, and resolving safety issues associated with these operations and with the tank wastes. Disposal activities involve designing equipment, processes, and facilities for retrieving wastes and processing them into a form that is suitable for long-term storage.

Chemical and radiological inventory information is generally derived using three approaches: 1) component inventories are estimated using the results of sample analyses; 2) component inventories are predicted using the Hanford defined waste (HDW) model based on process knowledge and historical information; or 3) a tank-specific process estimate is made based on process flowsheets, reactor fuel data, essential material usage, and other operating data. Not surprisingly, the information derived from these different approaches is often inconsistent.

An effort is underway to provide waste inventory estimates that will serve as the standard characterization for the various waste management activities (Hodgson and LeClair 1996). As part of this effort, an evaluation of available chemical information for tank 241-T-104 was performed, including the following:

- Data from two 1992 core samples

- An inventory estimate generated by the HDW model (Agnew et al. 1996b)

- Evaluation of the $1 \mathrm{C} / \mathrm{cladding}$ waste $(\mathrm{CW})$ flowsheet and plant throughput comparisons.

Based on this evaluation, a best-basis inventory was developed. In general, the sample-based TCR results were preferred when they were reasonable and consistent with other results.

The best-basis inventory for tank 241-T-104 is presented in Tables 3-1 and 3-2. A complete discussion of the methods and assumptions used to derive the best-basis inventory is presented in Appendix D. 
Table 3-1. Best-Basis Inventory Estimates for Nonradioactive Components in Tank 241-T-104 (November 19, 1996). ${ }^{1}$

\begin{tabular}{|c|c|c|}
\hline (1.1. & Tofol Irrentom & (8, Masis , or $\mathrm{E})$ \\
\hline $\mathrm{Al}$ & 33,500 & $S$ \\
\hline$\overline{B i}$ & 37,400 & $\mathrm{~S}$ \\
\hline $\mathrm{Ca}$ & 3,120 & $S$ \\
\hline$\overline{\mathrm{Cl}}$ & 1,440 & $S$ \\
\hline TIC as $\mathrm{CO}_{3}$ & 5,970 & $\mathrm{M}_{\mathrm{H}}$ \\
\hline $\mathrm{Cr}$ & 1,860 & $S$ \\
\hline$F$ & 18,400 & $\mathrm{~S}$ \\
\hline $\mathrm{Fe}$ & 19,000 & $S$ \\
\hline $\mathrm{Hg}$ & 26.2 & $\mathbf{M}_{\mathrm{H}}$ \\
\hline $\mathrm{K}$ & 191 & $S$ \\
\hline $\mathrm{La}$ & 0.0066 & $\mathbf{M}_{\mathrm{H}}$ \\
\hline$\overline{\mathrm{Mn}}$ & $\overline{133}$ & $\bar{S}$ \\
\hline $\mathrm{Na}$ & 134,000 & $S$ \\
\hline $\mathrm{Ni}$ & 22,600 & $S$ \\
\hline $\mathrm{NO}_{2}$ & 8,770 & $\mathrm{~S}$ \\
\hline $\mathrm{NO}_{3}$ & 125,000 & $S$ \\
\hline $\mathrm{OH}$ & NR & \\
\hline $\mathrm{Pb}$ & 0.87 & $\mathbf{M}_{\mathrm{H}}$ \\
\hline $\mathrm{P}$ as $\mathrm{PO}_{4}{ }^{2}$ & 162,000 & $\mathrm{~S}$ \\
\hline$\overline{\mathrm{Si}}$ & 14,000 & S \\
\hline $\mathrm{S}$ as $\mathrm{SO}_{4}$ & 8,390 & $S$ \\
\hline $\mathrm{Sr}$ & 213 & $\bar{S}$ \\
\hline TOC & NR & \\
\hline $\mathrm{U}_{\text {TOTAI. }}$ & 1,930 & S \\
\hline $\mathrm{Zr}$ & 80.6 & $S$ \\
\hline
\end{tabular}

Notes:

$\begin{array}{lll}\mathrm{NR} & = & \text { Not reported } \\ \mathrm{S} & = & \text { Sample-based } \\ \mathrm{M}_{\mathrm{H}}= & \text { Hanford Defined Waste model-based } \\ \mathrm{E} & = & \text { Engineering assessment-based }\end{array}$

${ }^{1}$ Based on 1992 core samples (see Appendix B)

${ }^{2}$ Inductively coupled plasma (ICP) much higher than ion chromatography (IC) 
HNF-SD-WM-ER-372 Rev. 1

Table 3-2. Best-Basis Inventory Estimates for Radioactive Components in Tank 241-T-104 (November 19, 1996). ${ }^{1}$

\begin{tabular}{|c|c|c|}
\hline 6. Arialyite & Total lintentory & (8., Gasis w \\
\hline${ }^{90} \mathrm{Sr}$ & 5,650 & $S$ \\
\hline${ }^{137} \mathrm{Cs}$ & 428 & $S$ \\
\hline${ }^{159} \mathrm{Eu}$ & 7.35 & S \\
\hline${ }^{234} \mathrm{U}$ & $0.140 \mathrm{~kg}$ & $S$ \\
\hline${ }^{235} \mathrm{U}$ & $13.0 \mathrm{~kg}$ & $S$ \\
\hline${ }^{236} \mathrm{U}$ & $0.130 \mathrm{~kg}$ & $S$ \\
\hline${ }^{238} \mathrm{U}$ & $1920 \mathrm{~kg}$ & $S$ \\
\hline${ }^{239} \mathrm{Pu}$ & 269 & $S$ \\
\hline${ }^{240} \mathrm{Pu}$ & 32.5 & $S$ \\
\hline${ }^{241} \mathrm{Am}$ & 30.5 & $S$ \\
\hline${ }^{241} \mathrm{Pu}$ & 184 & $S$ \\
\hline
\end{tabular}

Notes:

$\begin{array}{lll}\mathrm{S} & = & \text { Sample-based } \\ \mathrm{M}_{\mathbf{H}} & = & \text { Hanford Defined Waste model-based } \\ \mathrm{E} & = & \text { Engineering assessment-based }\end{array}$

'Based on 1992 core samples (see Appendix B) 
HNF-SD-WM-ER-372 Rev. 1

This page left blank intentionally. 


\subsection{RECOMMENDATIONS}

The sampling and analysis activities performed for tank 241-T-104 have met all requirements for the tank safety screening DQO (Dukelow et al. 1995). All analytical results for the safety screening DQO are well within the safety notification limits. A characterization best-basis inventory was also developed for the tank contents.

Table 4-1 summarizes the status of Project Hanford Management Contractor (PHMC) Program Office review and acceptance of the sampling and analysis results reported in this characterization report. All DQO issues required to be addressed by sampling and analysis are listed in column one of Table 4-1. The second column indicates whether the requirements of the DQO were met by the sampling and analysis activities performed and is answered with a "yes" or a "no." The third column indicates concurrence and acceptance by the program in TWRS that is responsible for the DQO that the sampling and analysis activities performed adequately meet the needs of the DQO. A "Yes" or "No" in column three indicates acceptance or disapproval of the sampling and analysis information presented in the TCR. If the results/information have not yet been reviewed, " $n / \mathrm{r}$ " is shown in the column. If the results/information have been reviewed, but acceptance or disapproval has not been decided, " $\mathrm{n} / \mathrm{d}$ " is shown in the column.

Table 4-1. Acceptance of Tank 241-T-104 Sampling and Analysis.

\begin{tabular}{|c|c|c|}
\hline Issue & $\begin{array}{l}\text { Eralination } \\
\text { Perforned }\end{array}$ & $\begin{array}{l}\text { PHMC Program OMree } \\
\text { Alceptance }\end{array}$ \\
\hline Safety Screening DQO & Yes & Yes \\
\hline
\end{tabular}

Table 4-2 summarizes the status of PHMC Program Office review and acceptance of the evaluations and other characterization information contained in this report. The evaluation specifically outlined in this report is the evaluation to determine whether the tank is safe, conditionally safe, or unsafe. Column one lists the evaluations performed in this report. Columns two and three are in the same format as Table 4-1. The manner in which concurrence and acceptance are summarized is also the same as that in Table 4-1. 
HNF-SD-WM-ER-372 Rev. 1

Table 4-2. Acceptance of Evaluation of Characterization

Data and Information for Tank 241-T-104.

\begin{tabular}{|c|c|c|}
\hline Issue & Evaluation Irorforned & $\begin{array}{l}\text { IHIMc Irogram } \\
\text { Ombe Arceptance }\end{array}$ \\
\hline $\begin{array}{l}\text { Safety categorization } \\
\text { (tank is safe) }\end{array}$ & Yes & Yes \\
\hline
\end{tabular}




\subsection{REFERENCES}

Agnew, S. F., R. A. Corbin, T. B. Duran, K. A. Jurgensen, T. P. Ortiz, and B. L. Young, 1996a, Waste Status and Transaction Record Summary for the Northwest Quadrant of the Hanford 200 East Area, WHC-SD-WM-TI-669, Rev. 1, Westinghouse Hanford Company, Richland, Washington.

Agnew, S. F., J. Boyer, R. A. Corbin, T. B. Duran, J. R. Fitzpatrick, K. A. Jurgensen, T. P. Ortiz, and B. L. Young, 1996b, Hanford Tank Chemical and Radionuclide Inventories: HDW Model Rev. 3, LA-UR-96-858, Los Alamos National Laboratory, Los Alamos, New Mexico.

Brown, T. M., S. J. Eberlein, J. W. Hunt, and T. J. Kunthara, 1996, Tank Waste Characterization Basis, WHC-SD-WM-TA-164, Rev. 2, Westinghouse Hanford Company, Richland, Washington.

Colton, N. G., 1996, Status Report: Pretreatment Chemistry Evaluation - Wash and Leach Factors for the Single-Shell Tank Waste Inventory, PNNL-11290, Pacific Northwest National Laboratory, Richland, Washington.

Dukelow, G. T., J. W. Hunt, H. Babad, and J. E. Meacham, 1995, Tank Safety Screening Data Quality Objective, WHC-SD-WM-SP-004, Rev. 2, Westinghouse Hanford Company, Richland, Washington.

Ecology, EPA and DOE, 1996, Hanford Federal Facility Agreement and Consent Order, as amended, Washington State Department of Ecology, U.S. Environmental Protection Agency, and U.S. Department of Energy, Olympia, Washington.

Hanlon, B. M., 1996, Waste Tank Summary Report for Month Ending September 30, 1996, WHC-EP-0182-102, Westinghouse Hanford Company, Richland, Washington.

Hill, J. G., W. I. Winters, B. C. Simpson, J. W. Buck, P. J. Chamberlain, and V. L. Hunter, 1991, Waste Characterization Plan for the Hanford Site Single-Shell Tanks, WHC-EP-0210, Rev. 3, Westinghouse Hanford Company, Richland, Washington.

Hodgson, K. M., and M. D. LeClair, 1996, Work Plan for Defining a Standard Inventory Estimate for Wastes Stored in Hanford Site Underground Tanks, WHC-SD-WM-WP-311, Rev. 1, Lockheed Martin Hanford Corporation, Richland, Washington. 
Kummerer, M., 1995, Topical Report on Heat Removal Characteristics of Waste Storage Tanks, WHC-SD-WM-SARR-010, Rev. 1, Westinghouse Hanford Company, Richland, Washington.

Pool, K. N., 1994, Single-Shell Tank Waste Characterization Tank 241-T-104, Core 45 and 46, WHC-SD-WM-DP-032, Rev. 0A, Westinghouse Hanford Company, Richland, Washington.

Public Law 101-510, 1990, "Safety Measures for Waste Tanks at Hanford Nuclear Reservation," Section 3137 of National Defense Authorization Act for Fiscal Year 1991.

Smith, D. M., 1986, Single-Shell Tank Isolation Safety Analysis Report, WHC-SD-WM-SAR-006, Rev. 2, Westinghouse Hanford Company, Richland, Washington.

WHC, 1996, T-104 Riser Preparation, Work Package WS-95-00291, Westinghouse Hanford Company, Richland, Washington. 
HNF-SD-WM-ER-372 Rev. 1

APPENDIX A

HISTORICAL TANK INFORMATION

A-1 
HNF-SD-WM-ER-372 Rev. 1

This page intentionally left blank. 


\section{APPENDIX A}

\section{HISTORICAL TANK INFORMATION}

Appendix A describes tank 241-T-104 based on historical information. For this report, historical information includes any information about the fill history, waste types, surveillance, or modeling data about the tank. This information is often useful for supporting or challenging conclusions based on sampling and analysis.

This appendix contains the following information:

- Section A1: Current status of the tank, including the current waste levels as well as the stabilization and isolation status of the tank.

- Section A2: Information about the design of the tank.

- Section A3: Process knowledge of the tank; i.e., the waste transfer history and the estimated contents of the tank based on modeling data.

- Section A4: Surveillance data for tank 241-T-104, including surface-level readings, temperatures, and a description of the waste surface based on photographs.

- Section A5: References for Appendix A.

Historical sampling results from a 1979 core sample and analysis effort are included in Appendix B.

\section{A1.0 CURRENT TANK STATUS}

As of September 30, 1996, tank 241-T-104 contained an estimated 1,408 kL (372 kgal) of non-complexed waste (Hanlon 1996). The total waste volume is estimated using a surface-level gauge. The volumes of the waste phases found in the tank are shown in Table A1-1.

The tank was removed from service in the second quarter of 1976, primary stabilized in 1978, and partially isolated in 1982. Stabilization of tank 241-T-104 began in March 1996, and was in progress at the time of the writing of this report. As of September 30, 1996, $317 \mathrm{~kL}$ (83.8 kgal) had been pumped from the tank (Hanlon 1996). The tank is classified as sound, is passively ventilated, and is not on the Watch List (Public Law 101-510). 
Table A1-1. Tank 241-T-104 Contents Status Summary (Hanlon 1996). ${ }^{1}$

\begin{tabular}{|l|l|}
\hline & \\
\hline Total waste & $1,408(372)$ \\
\hline Supernatant & $0(0)$ \\
\hline Sludge & $1,408(372)$ \\
\hline Saltcake & $0(0)$ \\
\hline Drainable interstitial liquid & $182(48)$ \\
\hline Drainable liquid remaining & $182(48)$ \\
\hline Pumpable liquid remaining & $170(45)$ \\
\hline
\end{tabular}

Note:

${ }^{1}$ Hanlon (1996). For definitions and calculation methods refer to Appendix C of Hanlon.

\section{A2.0 TANK DESIGN AND BACKGROUND}

Tank 241-T-104 was constructed during 1943 and 1944. It is one of twelve 2,010-kL (530-kgal) tanks in T Farm. These tanks were designed for nonboiling waste with a maximum fluid temperature of $104{ }^{\circ} \mathrm{C}\left(220^{\circ} \mathrm{F}\right)$. A typical T Farm tank contains 9 to 11 risers ranging in size from $10 \mathrm{~cm}(4 \mathrm{in.})$ to $1.1 \mathrm{~m} \mathrm{(42} \mathrm{in.)} \mathrm{in} \mathrm{diameter} \mathrm{that} \mathrm{provide}$ surface-level access to the underground tank. Generally, there is one riser through the center of the tank dome and four or five each on opposite sides of the dome.

Tank 241-T-104 entered service in March 1946 and is first in a three-tank cascading series with tanks $241-\mathrm{T}-105$ and $-\mathrm{T}-106$. These tanks are connected by a 7.6-cm (3-in.) cascade line. The bottom center elevation of tank 241-T-104 is $193.5 \mathrm{~m}(635 \mathrm{ft})$ above sea level. The tank cascades to tank 241-T-105 at $193.2 \mathrm{~m}$ (634 ft), which then cascades to tank 241-T-106, which has a bottom center elevation at $192.9 \mathrm{~m}(633 \mathrm{ft})$. The cascade overflow height is approximately $4.78 \mathrm{~m}$ (188 in.) from the tank bottom (as measured at the tank wall) and $60 \mathrm{~cm}(2 \mathrm{ft})$ below the top of the steel liner.

These single-shell tanks are constructed of 30-cm (1-ft)-thick reinforced concrete with a 6.4-mm (1/4-in.) mild carbon steel liner (ASTM A283 Grade C) on the bottom and sides and a $38-\mathrm{cm}(1.25-\mathrm{ft})$-thick domed concrete top. These tanks have a dished bottom with a $1.2-\mathrm{m}$ (4-ft) radius knuckle, a diameter of $22.9 \mathrm{ml}(75.0 \mathrm{ft})$ and a $5.2-\mathrm{m}(17-\mathrm{ft})$ operating depth. The tanks are set on a reinforced concrete foundation. 
A three-ply cotton fabric waterproofing was applied over the foundation and the steel tank. Four coats of primer paint were sprayed on all exposed interior tank surfaces. Tank ceiling domes were covered with three applications of magnesium zinc fluorosilicate wash. Lead flashing was used to protect the joint where the steel liner meets the concrete dome. Asbestos gaskets were used to seal the access holes in the tank dome. The tanks were waterproofed on the sides and top with tar and gunite. Each tank was covered with

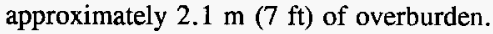

The surface level is monitored through riser 5. Riser 4 contains a thermocouple tree with 11 thermocouples attached at known elevations. Figure A2-1 is a plan view of the riser configuration. A list of tank 241-T-104 risers showing their sizes and general use is provided in Table A2-1.

A tank cross section showing the approximate waste level, along with a schematic of the tank equipment, is shown in Figure A2-2. Tank 241-T-104 has nine risers numbered 1 through 8 , and 13. Risers 2, 3, 6, 7, and 13 are all $30 \mathrm{~cm}$ (12 in.) in diameter. Risers $1,4,5$ and 8 are $10-\mathrm{cm}$ ( 4 in.) in diameter. Risers $2,3,6$, and 8 are tentatively available for sampling (Lipnicki 1996). Risers 2 and 3 are approximately 90 degrees counterclockwise from the inlet, and risers 6 and 8 are approximately 90 degrees clockwise from the inlet.

Tank 241-T-104 has four process inlet nozzles and one cascade overflow outlet located approximately $4.8 \mathrm{~m}$ (188 in.) from the tank bottom (as measured at the tank wall). Locations are shown on Figure A2-1. 
HNF-SD-WM-ER-372 Rev. 1

Figure A2-1. Riser Configuration for Tank 241-T-104.

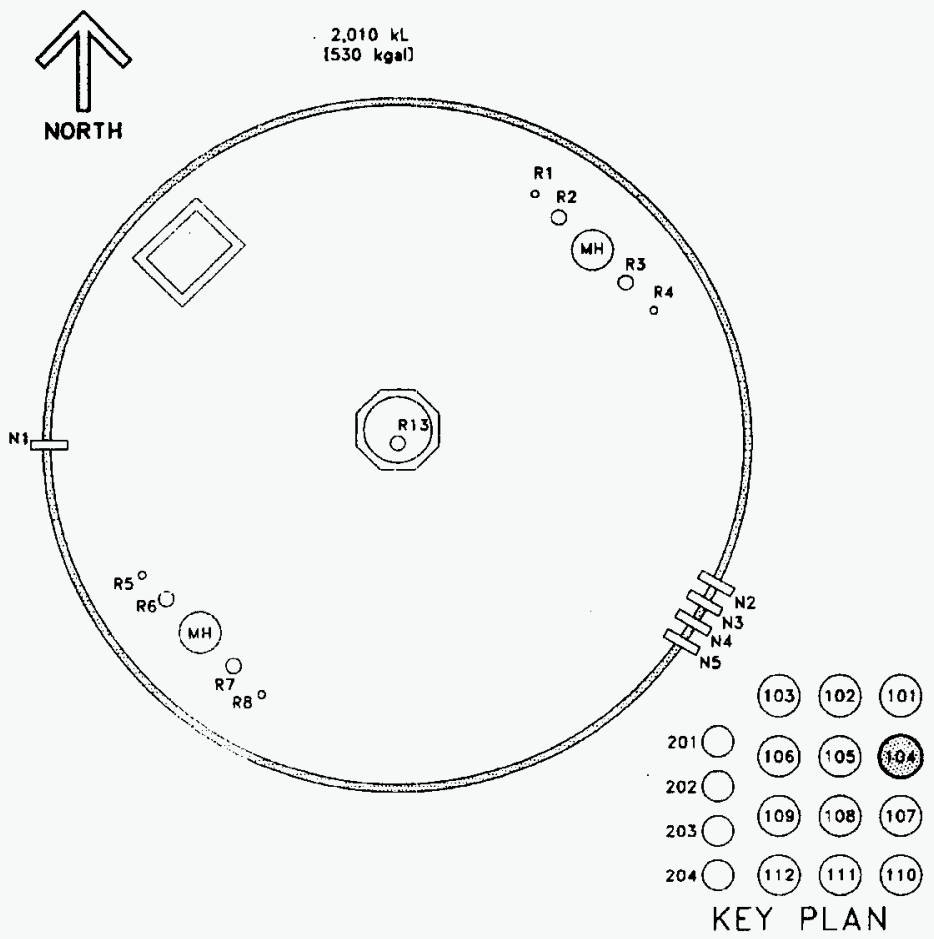




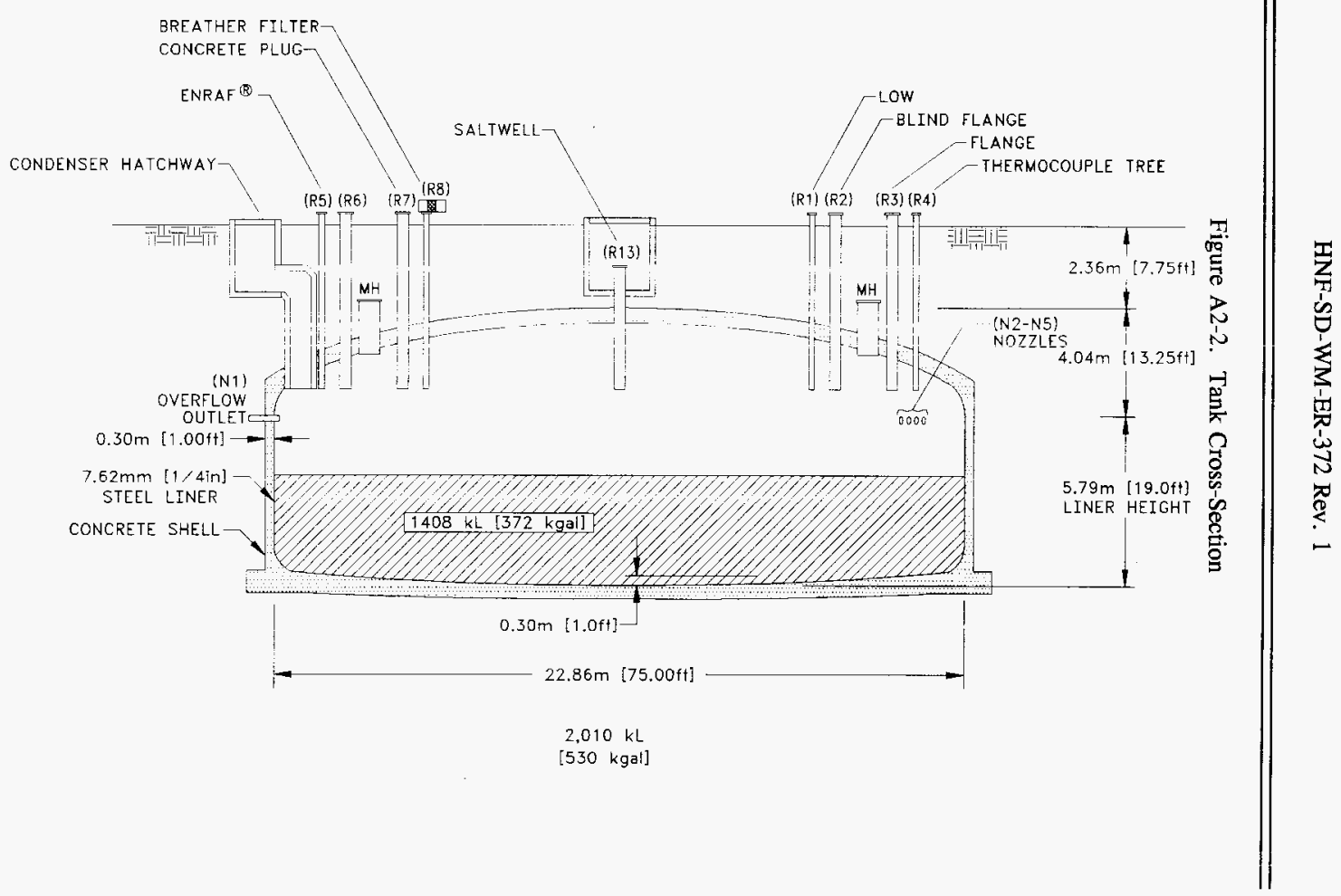


Table A2-1. Tank 241-T-104 Risers. ${ }^{1}$

\begin{tabular}{|c|c|c|}
\hline Honimer. & Wamprevinghes) & 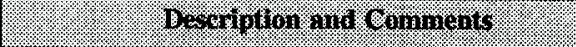 \\
\hline R1 & 4 in. & Liquid observation well (benchmarked $12 / 11 / 86$ ) \\
\hline $\mathrm{R} 2$ & 12 in. & Blind flange $^{2}$ \\
\hline R3 & 12 in. & Flange $^{2}$ \\
\hline R4 & $4 \mathrm{in.}$ & Thermocouple tree \\
\hline R5 & $4 \mathrm{in.}$ & ENRAF gauge \\
\hline R6 & 12 in. & Spare $^{2}$ (benchmarked 12/11/86) \\
\hline R7 & $12 \mathrm{in.}$ & Concrete plug \\
\hline R8 & 4 in. & Breather filter ${ }^{2}$ \\
\hline $\mathrm{R} 13$ & 12 in. & Saltwell screen (benchmarked) \\
\hline N1 & 3 in. & Outlet overflow nozzle \\
\hline $\mathrm{N} 2$ & 3 in. & Process inlet nozzle \\
\hline N3 & 3 in. & Process inlet nozzle \\
\hline N4 & 3 in. & Process inlet nozzle \\
\hline N5 & $3 \mathrm{in.}$ & Process inlet nozzle \\
\hline
\end{tabular}

Notes:

'Alstad (1993), Tran (1993), Vitro Engineering (1979).

${ }^{2}$ Available for sampling (Lipnicki 1996).

\section{A3.0 PROCESS KNOWLEDGE}

The following sections: 1) provide information about the transfer history of tank 241-T-104; 2) describe the process wastes that made up the transfers; and 3) give an estimate of the current tank contents based on transfer history. 


\section{A3.1 WASTE TRANSFER HISTORY}

Table A3-1 summarizes the waste transfer history of tank 241-T-104 (Agnew et al. 1996b). Waste was initially added to tank 241-T-104 in March 1946 with the addition of first cycle decontamination waste from the bismuth phosphate process (1C1) from T Plant. The tank was filled by August 1946. Cascading had not begun at this time, but did begin in the second quarter of 1948 with the addition to the tank of more $1 \mathrm{Cl}$ waste from T Plant. With the exception of a transfer of $227 \mathrm{~kL}$ (60 kgal) of supernatant to tank 241-TX-118 in the second quarter of 1951, the tank's activity consisted of cascading 1C2 waste from T Plant to tank 241-T-105 until the third quarter of 1954. Tank 241-TY-103 received 182 kL (48 kgal) of supernatant from tank 241-T-104 in the third quarter of 1969, tank 241-T-101 received $57 \mathrm{~kL}$ (15 kgal) in the first quarter of 1976, and tank 241-AW-102 received $144 \mathrm{~kL}$ (38 kgal) in the third quarter of 1992.

Table A3-1. Tank 241-T-104 Major Transfers. ${ }^{1,2}$ (2 sheets)

\begin{tabular}{|c|c|c|c|c|c|}
\hline \multirow{2}{*}{ Irancier } & \multirow{2}{*}{$\begin{array}{l}\text { Iranstel } \\
\text { Destination }\end{array}$} & \multirow[b]{2}{*}{ Waste T Ype } & \multirow[b]{2}{*}{ Thime Period } & \multicolumn{2}{|c|}{ 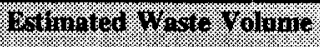 } \\
\hline & & & & 186 & legel \\
\hline T Plant & & $1 \mathrm{Cl}$ & $1946-1951$ & 6,386 & 1,687 \\
\hline & $241-\mathrm{T}-105$ & $1 \mathrm{C} 1$ & $1946-1951$ & $-4,122$ & $-1,089$ \\
\hline & $241-\mathrm{TX}-118$ & SU & 1951 & -227 & -60 \\
\hline T-Plant & & $1 \mathrm{C} 2$ & $1952-1954$ & 6,711 & 1,773 \\
\hline & 241-T-105 & $1 \mathrm{C} 2$ & $1952-1954$ & $-6,832$ & $-1,805$ \\
\hline & 241-TY-103 & SU & 1969 & -182 & -48 \\
\hline & 241-T-101 & SU & 1976 & -57 & -15 \\
\hline & 241-AW-102 & SWLIQ & 1992 & -144 & -38 \\
\hline 4 & $244-\mathrm{TX}^{3}$ & SWLIQ & 1996 & -318 & $-84^{4}$ \\
\hline
\end{tabular}


Table A3-1. Tank 241-T-104 Major Transfers. ${ }^{1,2}$ (2 sheets)

Notes:

1C First-cycle decontamination waste from the $\mathrm{BiPO}_{4}$ process (contains 10 percent of the fission products and 1 percent plutonium and often included cladding waste). 1C1 waste was produced from 1944 until 1949. IC2 waste was produced from 1950 until 1956.

SU Supernatant (liquid considered free of contamination to the extent it could be pumped to a crib).

SWLIQ Saltwell liquid waste (dilute non-complexed liquid pumped from single-shell tanks to double-shell tanks).

'Agnew et al. (1996b)

${ }^{2}$ Because only major transfers are listed, the sum of these transfers will not equal the current tank waste volume.

${ }^{3}$ Saltwell liquid was pumped to double-contained receiver tank 244-TX and is destined for transfer to tank 241-SY-102.

${ }^{4}$ Volume transferred as of September $30,1996$.

\section{A3.2 HISTORICAL ESTIMATION OF TANK CONTENTS}

This section provides an estimate of the contents of tank 241-T-104 based on historical transfer data. The historical data used for this historical tank content estimate (HTCE) are the Hanford defined waste (HDW) list (Agnew et al. 1996a), the tank layer model (TLM) (Agnew et al. 1996a), and the waste status and transaction record summary (WSTRS) (Agnew et al. 1996b). The HTCEs are documented in Hanford Tank Chemical and Radionuclide Inventories: HDW Model Rev. 3 (Agnew et al. 1996a). The WSTRS is a compilation of available waste transfer and volume status data. The HDW provides the assumed typical compositions for 50 separate waste types. In some cases, the available data are incomplete, reducing the usability of the transfer data and the modeling results derived from it. The TLM takes the WSTRS data, models the waste deposition processes, and, using data from the HDW, derives the primary waste layers in the tank. Thus, these model predictions can only be considered estimates that require further evaluation using analytical data.

Based on Agnew et al. (1996a) and Agnew et al. (1996b), tank 241-T-104 contains $704 \mathrm{~kL}$ $(186 \mathrm{kgal})$ of $1 \mathrm{C} 1$ waste and $969 \mathrm{~kL}$ ( $256 \mathrm{kgal})$ of $1 \mathrm{C} 2$ waste. Because the estimate is for the tank contents as of the fourth quarter of 1993 and liquid has since been pumped from the tank, the HDW waste volume estimates are greater than the current waste volume in the tank. Figure A3-1 shows a graphical representation of the estimated waste type and volume 
for the tank layer. The historical tank content estimate model predicts $1 \mathrm{C} 1$ waste to contain greater than 1.00 weight percent of sodium, bismuth, iron, hydroxide, nitrate, and phosphate; aluminum, calcium, nitrite, carbonate, sulfate, silicate, and fluoride are expected to be present in greater than 0.100 weight percent quantities. 1C2 waste is predicted to contain greater than 1 weight percent of sodium, aluminum, hydroxide, nitrate, and phosphate; bismuth, calcium, iron, carbonate, sulfate, silicate, and fluoride are expected to be present in greater than 0.100 weight percent quantities. Table A3-2 shows the historical estimate of the expected waste constituents and their concentrations.

Figure A3-1. Tank Layer Model.

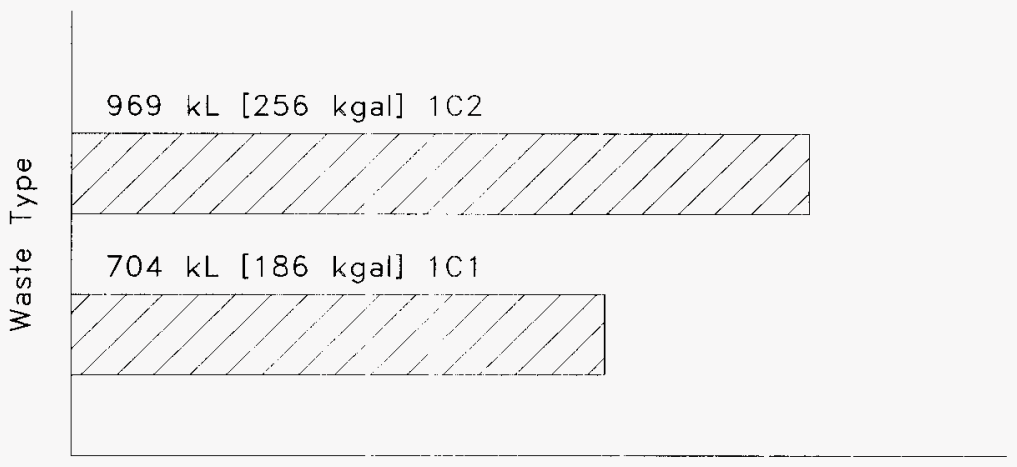

Waste Volume 
HNF-SD-WM-ER-372 Rev. 1

Table A3-2. Historical Tank Inventory Estimate. ${ }^{1,2}$ (2 sheets)

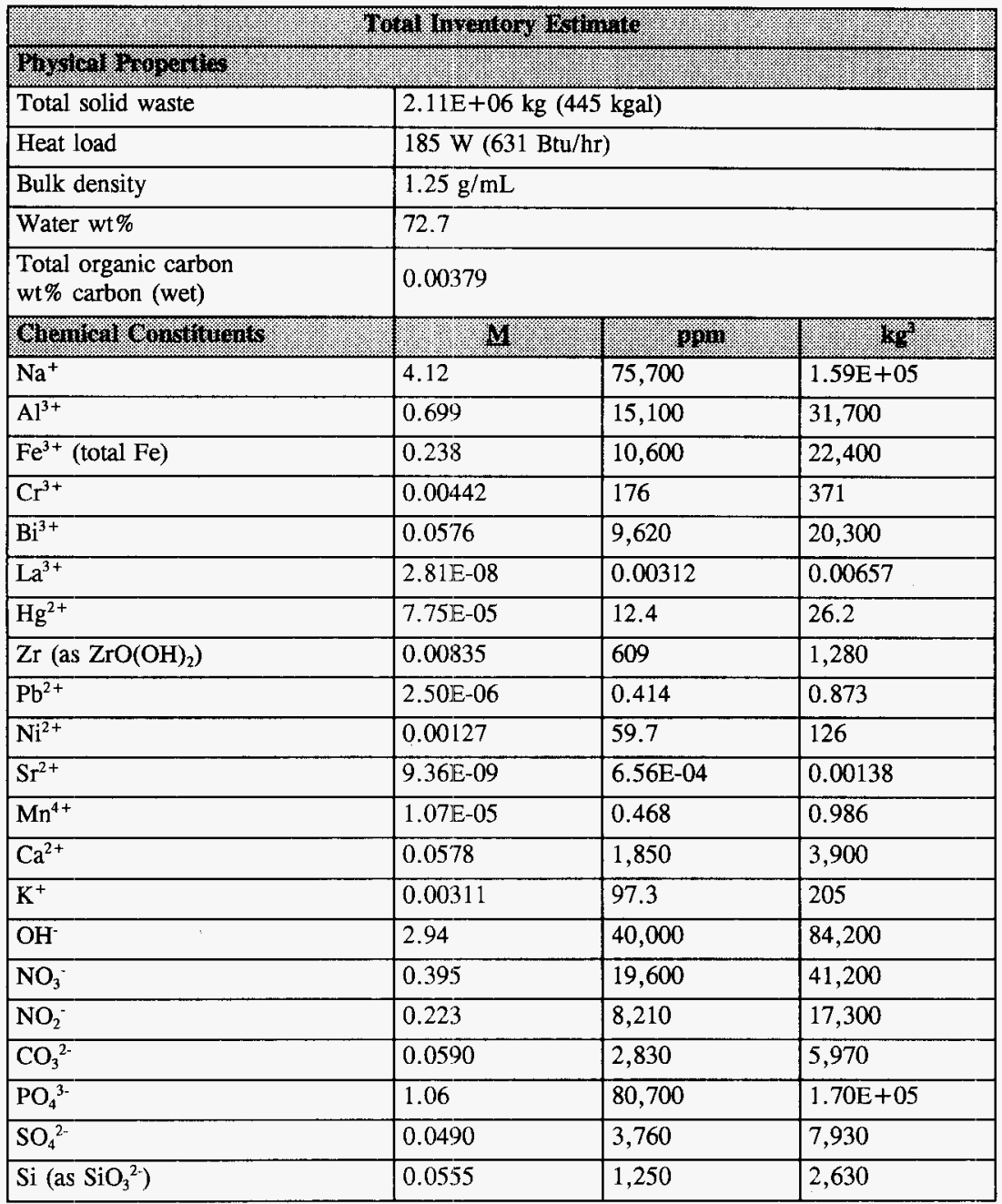


HNF-SD-WM-ER-372 Rev. 1

Table A3-2. Historical Tank Inventory Estimate. ${ }^{1,2}$ (2 sheets)

\begin{tabular}{|c|c|c|c|}
\hline \multicolumn{4}{|c|}{ 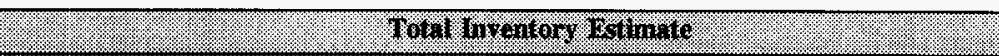 } \\
\hline 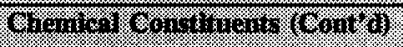 & 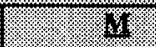 & (2) pon & $\sqrt{18}$ \\
\hline $\mathrm{F}^{-}$ & 0.180 & 2,730 & 5,760 \\
\hline $\mathrm{Cl}^{-}$ & 0.0142 & 402 & 847 \\
\hline citrate & $8.84 \mathrm{E}-05$ & 13.4 & 28.2 \\
\hline EDTA $^{4-}$ & $6.86 \mathrm{E}-05$ & 15.8 & 33.3 \\
\hline HEDTA $^{3-}$ & $1.30 \mathrm{E}-04$ & 28.6 & 60.2 \\
\hline glycolate & $3.70 \overline{\mathrm{E}-04}$ & 22.2 & 46.7 \\
\hline acetate & $2.21 \mathrm{E}-05$ & 1.04 & 2.20 \\
\hline oxalate & $2.40 \mathrm{E}-08$ & 0.00169 & 0.00356 \\
\hline DBP & $5.37 \mathrm{E}-05$ & 11.4 & 24.1 \\
\hline butanol & $5.37 \mathrm{E}-05$ & 3.18 & 6.70 \\
\hline $\mathrm{NH}_{3}$ & $5.42 \mathrm{E}-04$ & 7.36 & 15.5 \\
\hline $\mathrm{Fe}(\mathrm{CN})_{6}{ }^{4}$ & 0 & 0 & 0 \\
\hline 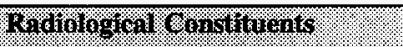 & .91: & $1 \%$ & $\sqrt{1.96}$ \\
\hline $\mathrm{Pu}$ & & 0.0126 & $0.442 \mathrm{~kg}$ \\
\hline$U$ & $6.34 \mathrm{E}-04 \mathrm{M}$ & $121 \mu \mathrm{g} / \mathrm{g}$ & $254 \mathrm{~kg}$ \\
\hline $\mathrm{Cs}$ & 0.02 .26 & 18.1 & 38,100 \\
\hline $\mathrm{Sr}$ & $5.52 \mathrm{E}-04$ & 0.441 & 930 \\
\hline
\end{tabular}

Notes:

'Agnew et al. (1996a)

${ }^{2}$ The HTCE predictions have not been validated and should be used with caution.

${ }^{3}$ Differences exist among the inventories in this column and the inventories calculated from the two sets of concentrations. 


\section{A4.0 SURVEILLANCE DATA}

Tank 241-T-104 surveillance consists of surface-level measurements (liquid and solid), temperature monitoring inside the tank (waste and headspace), and leak detection well (drywell) monitoring for radioactivity outside the tank. Surveillance data provide the basis for determining tank integrity.

Liquid-level measurements can indicate if the tank has a major leak. Solid surface-level measurements provide an indication of physical changes and consistencies of the solid layers of a tank. Drywells located around the tank perimeter may show increased radioactivity due to leaks.

\section{A4. 1 SURFACE-LEVEL READINGS}

Tank 241-T-104 is considered sound. Since January 1996, surface levels are measured quarterly through riser 5 using an ENRAF' gauge. Prior to January 1996, a manual tape was used to measure the waste surface level. The leak detection criteria for tank 241-T-104 are an increase of $5.1 \mathrm{~cm}$ (2.0 in ) from the baseline value and no value for a decrease. From January 1993 to January 1996 , readings ranged from $391.9 \mathrm{~cm}$ (154.3 in.) to $395.0 \mathrm{~cm}$ (155.5 in.). A level history graph of the volume measurements is presented in Figure A4-1. The surface-level plot indicates a steady waste level from January 1991 to January 1996. However, as discussed in Section A1.0, saltwell pumping began in March 1996 and the surface level has been decreasing as the liquid has been pumped. As of October 2, 1996, the: measured waste level was $351.8 \mathrm{~cm}$ (138.5 in.).

Tank 241-T-104 has a liquid observation well, located in riser 1. The tank is monitored weekly with a neutron probe and on request with a gamma probe to determine the interstitial liquid level. The maximum deviations from the baseline are a $9 \mathrm{~cm}(0.3 \mathrm{ft})$ increase and a $12 \mathrm{~cm}(0.4 \mathrm{ft})$ decrease. Tank $241-\mathrm{T}-104$ has five identified drywells. Drywell 50-04-10 is active with readings above 50 counts per second and below 200 counts per second. Drywells 50-04-03, 50-04-07, and 50-04-08 were active prior to 1990 but currently have readings less than 50 counts per second (Brevick et al. 1995).

\section{A4.2 INTERNAL TANK TEMPERATURES}

Tank 241-T-104 has a single thermocouple tree with 11 thermocouples to monitor the waste temperature through riser 4 . Thermocouple 1 is $36.6 \mathrm{~cm}(1.2 \mathrm{ft})$ from the bottom of the tank. Thermocouples 2 through 9 are spaced at $61-\mathrm{cm}(2-\mathrm{ft})$ intervals above thermocouple 1 . Thermocouples 9 though 11 are at $1.22-\mathrm{m}(4-\mathrm{ft})$ intervals.

${ }^{1}$ Trademark of ENRAF Corporation, Houston, Texas. 
Manual thermocouple readings are available between February 1, 1977 and July 1, 1995. Readings were recorded as often as quarterly in 1977 and 1978, but occurred less frequently for the later years. There are no manual thermocouple readings for 1979, 1982, 1984 through 1986, and 1990. On June 2, 1994, the Tank Monitoring and Control System began automatic recording of thermocouple measurements for thermocouples 1 through 8 and 11 on a daily basis. With few exceptions, the daily thermocouple readings are continual and nonsuspect. There are no readings available for thermocouples 9 and 10 after July 1,1995 .

The average tank temperature from February 1977 to November 1996 is $17.9{ }^{\circ} \mathrm{C}\left(64.2^{\circ} \mathrm{F}\right)$, the minimum is $11.5^{\circ} \mathrm{C}\left(52.7^{\circ} \mathrm{F}\right)$, and the maximum is $25.6^{\circ} \mathrm{C}\left(78^{\circ} \mathrm{F}\right)$. The average temperature for the past year was $17.5^{\circ} \mathrm{C}\left(63.6^{\circ} \mathrm{F}\right)$, the minimum was $11.5^{\circ} \mathrm{C}\left(52.7^{\circ} \mathrm{F}\right)$, and the maximum was $21.6^{\circ} \mathrm{C}\left(70.88^{\circ} \mathrm{F}\right)$. On November 5,1996 , the low temperature, $17.3^{\circ} \mathrm{C}\left(63^{\circ} \mathrm{F}\right)$ was from thermocouple $\mathrm{l}$, and the high temperature, $19.6^{\circ} \mathrm{C}\left(67.3^{\circ} \mathrm{F}\right)$, was from thermocouple 8 . Plots of the thermocouple readings can be found in the supporting, document for the HTCE (Brevick et al. 1995). Figure A4-2 shows a graph of the weekly high temperature.

\section{A4.3 TANK 241-T-104 PHOTOGRAPHS}

In the photographs taken in 1989, the waste in tank 241-T-104 appears uniform, with small puddles of yellow liquid. The waste is tan in color, and resembles wet paste. Indentations appear on the surface of the waste which may have been caused by gas bubbles. A manual tape, saltwell screen, thermowell, liquid observation well, and some nozzles are identified, as well as a discarded measurement tape on the surface of the waste. According to photographer's notes, a photograph taken in 1980 more clearly shows the tank walls, with tar rings. The photograph has not been located. Since the tank is currently being salt well liquid pumped, the photographs may not represent the current tank waste surface.. 
Figure A4-1. Tank 241-T-104 Level History.

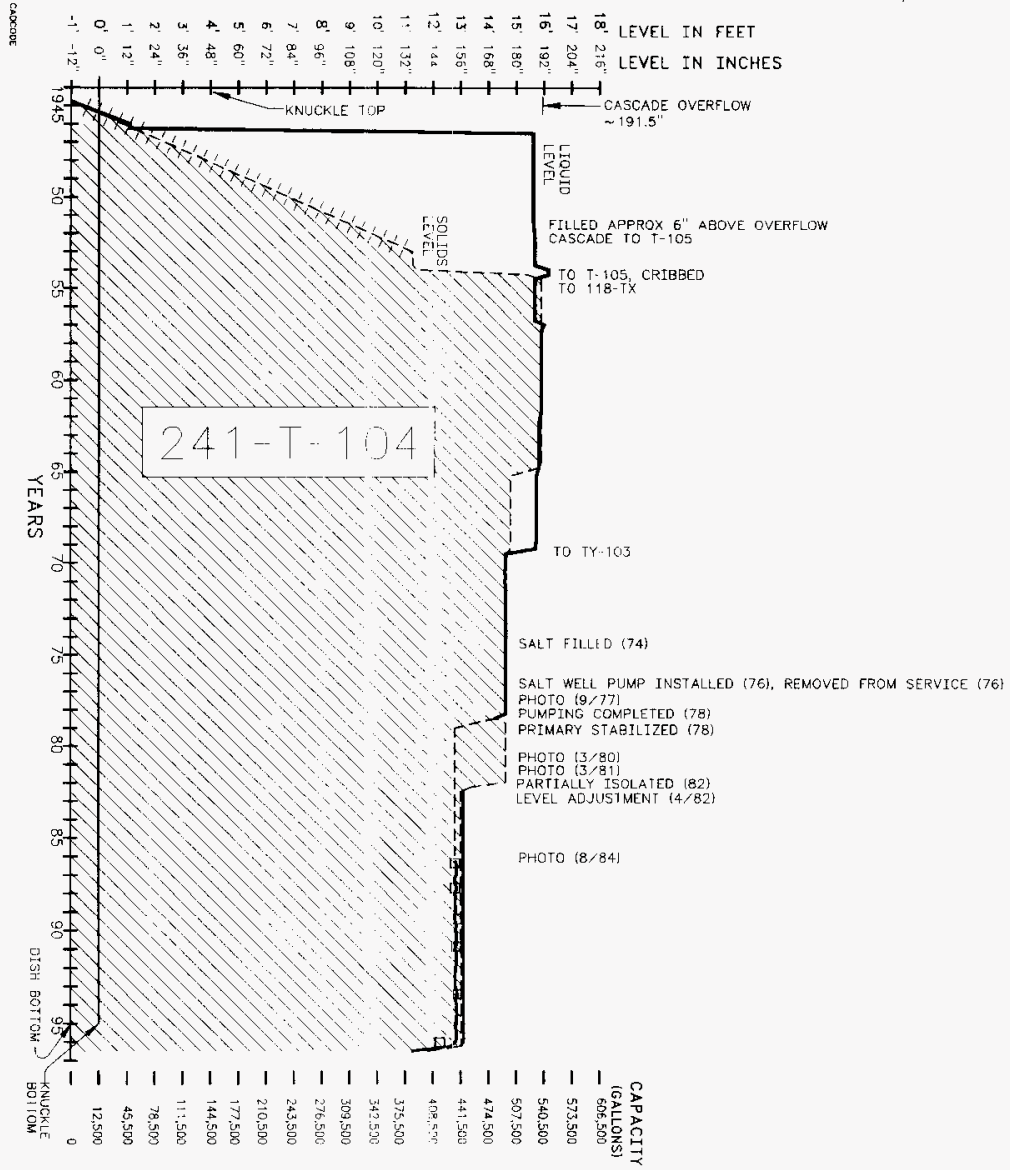


Figure A4-2. Tank 241-T-104 High Temperature Plot.

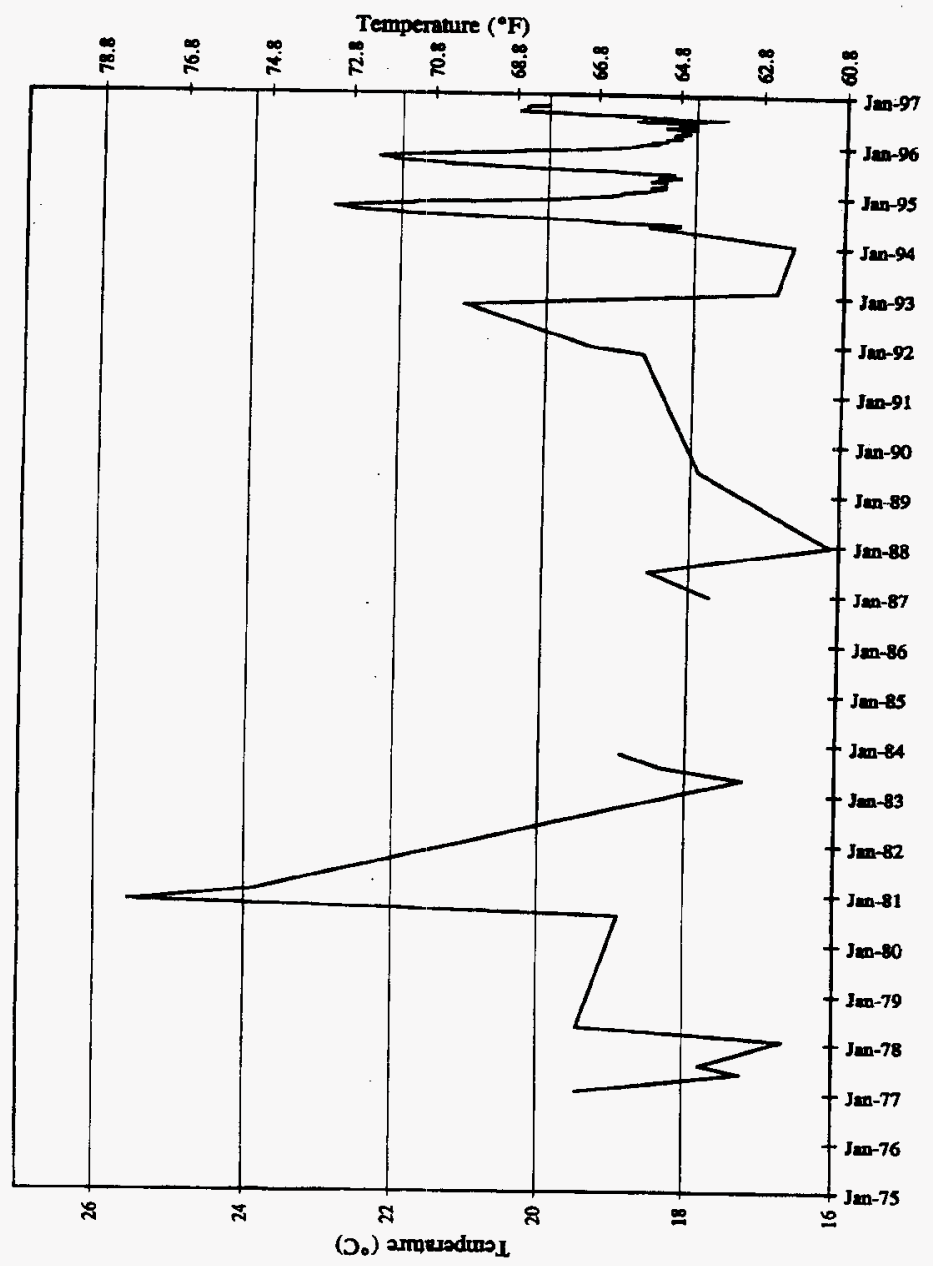




\section{A5.0 APPENDIX A REFERENCES}

Agnew, S. F., J. Boyer, R. A. Corbin, T. B. Duran, J. R. Fitzpatrick, K. A. Jurgensen, T. P. Ortiz, and B. L. Young, 1996a, Hanford Tank Chemical and Radionuclide Inventories: HDW Model Rev. 3, LA-UR-96-858, Los Alamos National Laboratory, Los Alamos, New Mexico.

Agnew, S. F., R. A. Corbin, T. B. Duran, K. A. Jurgensen, T. P. Ortiz, and B. L. Yourg, 1996b, Waste Status and Transaction Record Summary for the Northwest Quadrant of the Hanford 200 East Area, WHC-SD-WM-TI-669, Rev. 1, Westinghouse Hanford Company, Richland, Washington.

Alstad, A. T., 1993, Riser Configuration Document for Single-Shell Waste Tanks, WHC-SD-WM-RE-TI-053, Rev. 9, Westinghouse Hanford Company, Richland, Washington.

Brevick, C. H., L. A. Gaddis, and W. W. Pickett, 1995, Supporting Document for the Historical Tank Content Estimate for T Tank Farm, WHC-SD-WM-ER-320, Rev. 0, Westinghouse Hanford Company, Richland, Washington.

Hanlon, B. M., 1996, Waste Tank Summary Report for Month Ending September 30, 1996, WHC-EP-0182-102, Westinghouse Hanford Company, Richland, Washington.

Lipnicki, J., 1996, Waste Tank Risers Available for Sampling, WHC-SD-WM-TI-710, Rev. 3, Westinghouse Hanford Company, Richland, Washington.

Public Law 101-510, 1990, "Safety Measures for Waste Tanks at Hanford Nuclear Reservation," Section 3137 of National Defense Authorization Act for Fiscal Year 1991.

Tran, T. T., 1993, Thermocouple Status Single-Shell and Double-Shell Waste Tanks, WHC-SD-WM-TI-553, Rev. 0, Westinghouse Hanford Company, Richland, Washington.

Vitro Engineering Corporation, 1979, Piping Waste Tank Isolation 241-T-104, Drawing Number H-2-73061, Vitro Engineering Corporation, Richland, Washington. 
HNF-SD-WM-ER-372 Rev. 1

APPENDIX B

SAMPLING OF TANK 241-T-104 
HNF-SD-WM-ER-372 Rev. 1

This page intentionally left blank. 


\section{APPENDIX B}

\section{SAMPLING OF TANK 241-T-104}

Appendix B provides sampling and analysis information for each known sampling event for tank 241-T-104 and provides an assessment of the core sample results.

- Section B1: Tank Sampling Overview

- Section B2: Analytical Results

- Section B3: Interpretations of Characterization Results

- Section B4: References for Appendix B.

Future sampling of tank $241-\mathrm{T}-104$ will be appended to the above list.

\section{B1.0 TANK SAMPLING OVERVIEW}

This section describes the August 1992 core sampling and analysis events for tank 241-T-104. Core samples were obtained and analyzed to satisfy the requirements of the Waste Characterization Plan for the Hanford Site Single-Shell Tanks (Hill et al. 1991). Documentation for laboratory work in support of Hill et al. (1991) can be found in Sampling and Analysis of Ten Single-Shell Tanks Revs. 0 and 1 (Silvers 1991), Technical Project Plan (Smith 1992), and Pacific Northwest Laboratory Single-Shell Tank Waste Characterization Project (16021) and Single-Shell Tank Safety Analysis Project (19091) Technical Project Plan (Jones 1993). Further discussions of the sampling and analysis procedures can be found in the Tank Characterization Reference Guide (DeLorenzo et al. 1994). The results from these sample events were reported in Pool (1994) and are discussed in Section B2.0. Vapor phase measurements were made in 1996 and a core sample was taken from this tank in 1979.

\section{B1.1 1992 CORE SAMPLING EVENT}

\section{B1.1.1 Description of Sampling Event}

Two core samples were collected from tank 241-T-104. Core 45 was obtained from riser 3 on August 20 and 26, and core 46 was obtained from riser 6 on August 27 and 28, 1992. 
The core samples were received at the 222-S Laboratory on September 14, 16, and 17, 1992. Core 45 was extruded September 29 through October 7, 1992. Core 46 was extruded October 7 through October 22, 1992. Seventeen unhomogenized segment samples $(9$ from core 45 and 8 from core 46 ), 4 core composite samples ( 2 from each core), a homogenization sample from segment 9 of each core, and 2 field blanks were shipped to Pacific Northwest National Laboratory (PNNL) for selected analyses. The samples arrived at PNNL November 19, 1992. The bulk of the analyses were performed at the Westinghouse Hanford Company 222-S Laboratory.

Core sampling was used because of the phase of the waste (solid versus liquid), the depth of the waste, and the expectation that a full vertical profile of the waste would be obtained. Normal paraffin hydrocarbon was used as hydrostatic head fluid. A vertical profile is used to satisfy the safety screening DQO. Safety screening analyses include: total alpha to determine criticality, DSC to ascertain the fuel energy value, and thermogravimetric analysis (TGA) to obtain the total moisture content. In addition, combustible gas meter readings in the tank headspace were required to measure vapor flammability. The current revision of the safety screening DQO (Dukelow et al. 1995) also requires bulk density measurements. Although the tank was sampled and analyzed before the existence of the safety screening DQO, the analytical results can be compared with the requirements of the DQO.

Sampling and analytical requirements from the safety screening DQO are summarized in Table B1-1.

Table B1-1. Integrated Data Quality Objective Requirements for Tank 241-T-104.'

\begin{tabular}{|c|c|c|c|}
\hline$\frac{1}{4}$ & . & 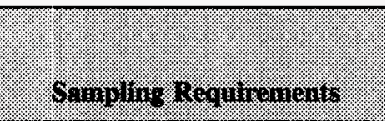 & (2.). \\
\hline Core sampling & Safety screening & $\begin{array}{l}\text { Core samples from a minimum } \\
\text { of two risers separated radially } \\
\text { to the maximum extent possible. }\end{array}$ & $\begin{array}{l}\text { - Energetics } \\
\text { - Moisture Content } \\
\text { - Total Alpha }\end{array}$ \\
\hline $\begin{array}{l}\text { Combustible gas } \\
\text { meter reading }\end{array}$ & & $\begin{array}{l}\text { Measurement in a minimum of } \\
\text { one location within tank vapor } \\
\text { space. }\end{array}$ & $\begin{array}{l}\text { Flammable Gas } \\
\text { Concentration }\end{array}$ \\
\hline
\end{tabular}

Note:

${ }^{1}$ Dukelow et al. (1995) 


\section{B1.1.2 Sample Handling}

The statement of work was not strictly followed when characterizing drainable liquids. The statement of work requires that a liquid composite sample be prepared from all segments that have $25 \mathrm{~mL}$ or more drainable aqueous liquid, and that a full characterization be performed on that composite. The statement of work also includes a provision for cases when there are not enough segments containing greater than $25 \mathrm{~mL}$ drainable liquid to prepare approximately $100 \mathrm{~mL}$ of liquid composite. This provision states that when not enough sample can be obtained for a liquid composite, the liquid shall be blended back into the solid composite samples.

About $25 \mathrm{~mL}$ of aqueous drainable liquid were obtained for Core 46 , segment 7 . Because no other aqueous drainable liquid greater than $25 \mathrm{~mL}$ was collected from Core 46 , the statement of work indicated that the liquid was to be blended into the solid composite samples. This procedure was not followed for Core 46 drainable liquids. Instead, the liquid was saved, and the solid composites were sent out for characterization without blending the liquid in. This resulted in an aqueous sample that did not have enough volume for a full characterization. Drainable liquids were recovered from other segments, but were either small volumes or found to consist primarily of normal paraffin hydrocarbon (NPH) used as a hydrostatic head fluid during sampling. Immiscibility tests and specific gravity measurements were used to determine if a liquid was NPH.

Because not enough liquid sample was available for a full characterization, analysis was prioritized, and the sample was analyzed until there was no longer enough sample left for further characterization work. Analyses not performed on the drainable liquid because of the limited sample volume are: $\mathrm{NO}_{2}$ by spectrophotometry, mercury, arsenic, selenium, ammonia, SVOA, total uranium, total beta, ${ }^{14} \mathrm{C},{ }^{3} \mathrm{H},{ }^{129} \mathrm{I},{ }^{237} \mathrm{~Np},{ }^{79} \mathrm{Se},{ }^{90} \mathrm{Sr},{ }^{99} \mathrm{Tc}$, and ${ }^{241} \mathrm{Am}$ by atomic energy analysis. Table B1-2 presents a description of the core samples.

Segment 2 of core 46 was used to test homogenization techniques. Two composite samples were formed from cores 45 and 46. 
Table B1-2. Tank 241-T-104 Sample Description. ${ }^{1}$ (3 Sheets)

\begin{tabular}{|c|c|c|c|}
\hline Segrnerit & $\begin{array}{l}\text { Weight } \\
\text { (erams) }\end{array}$ & $\begin{array}{l}\text { Sampier } \\
\text { Recovery } \\
(9)^{2}\end{array}$ & Gainple Characteristles \\
\hline 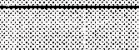 & \multicolumn{3}{|c|}{ 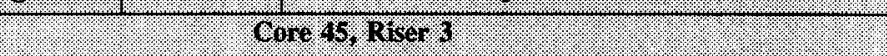 } \\
\hline 1 & $\begin{array}{c}15.66 \\
\text { (solids) }\end{array}$ & 5 & $\begin{array}{l}\text { A tiny amount of liquid was recovered, but not } \\
\text { enough to observe characteristics. The sampler } \\
\text { contained a small amount (approximately } 9 \mathrm{~mL} \text { ) of } \\
\text { light brown, mud-like solids. }\end{array}$ \\
\hline 2 & $\begin{array}{l}169.49 \\
\text { (solids) }\end{array}$ & 90 & $\begin{array}{l}\text { The sampler was nearly filled with solids } \\
(168 \mathrm{~mL}) \text {, with portions of solids towards the top } \\
\text { of the sampler separated by air gaps. The solids } \\
\text { were light brown in color and creamy in } \\
\text { consistency. The segment was homogeneous in } \\
\text { appearance. There were no drainable liquids. }\end{array}$ \\
\hline 3 & $\begin{array}{l}186.41 \\
\text { (solids) }\end{array}$ & 100 & $\begin{array}{l}\text { The sampler was completely full of solids and had } \\
\text { a small amount of drainable liquid, but not enough } \\
\text { to observe characteristics. The solids were tan to } \\
\text { light-brown in color, with a creamy consistency. } \\
\text { The segment was homogeneous in appearance. }\end{array}$ \\
\hline 4 & $\begin{array}{c}168.4 \\
\text { (solids) }\end{array}$ & 75 & $\begin{array}{l}\text { No drainable liquids were recovered. The solids } \\
\text { were tan to light brown in color and had a runny } \\
\text { consistency. The segment was homogeneous in } \\
\text { appearance. } 140 \mathrm{~mL} \text { of solids were recovered. }\end{array}$ \\
\hline 5 & $\begin{array}{l}153.91 \\
\text { (solids) }\end{array}$ & 95 & $\begin{array}{l}\text { The sampler was nearly full of solids }(178 \mathrm{~mL}) \text {, } \\
\text { with a trace of drainable liquid present. The solids } \\
\text { were tan to light brown in color and had a soft, } \\
\text { muddy consistency. The segment was } \\
\text { homogeneous in appearance, with the exception of } \\
\text { several places on the segment that were relatively } \\
\text { more wet than others. }\end{array}$ \\
\hline 6 & $\begin{array}{c}131.9 \\
\text { (solids) }\end{array}$ & 75 & $\begin{array}{l}140 \mathrm{~mL} \text { of solids and approximately } 10 \mathrm{~mL} \\
(8.05 \mathrm{~g}) \text { of liquid were recovered (consisting of } \\
\text { mostly NPH) being drainable. Segment appeared } \\
\text { moist and runny, and was light brown in color. }\end{array}$ \\
\hline
\end{tabular}


Table B1-2. Tank 241-T-104 Sample Description.' (3 Sheets)

\begin{tabular}{|c|c|c|c|}
\hline Segment & Weight & Rerovely & 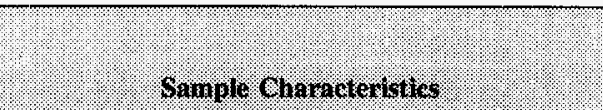 \\
\hline \multicolumn{4}{|c|}{ 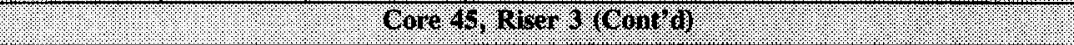 } \\
\hline 7 & $\begin{array}{c}170.96 \\
\text { (solids) } \\
11.64 \\
\text { (liquid) }\end{array}$ & 94 & $\begin{array}{l}10 \mathrm{~mL} \text { of drainable liquid and } 165 \mathrm{~mL} \text { solids were } \\
\text { recovered. Solids were light brown in color and } \\
\text { had a consistency similar to the previous segment. } \\
\text { It is hypothesized that the NPH is what makes the } \\
\text { solid so runny. }\end{array}$ \\
\hline 8 & $\begin{array}{l}184.56 \\
\text { (solids) }\end{array}$ & 100 & $\begin{array}{l}\text { The sampler was completely full. A trace of } \\
\text { drainable liquid was recovered. The appearance of } \\
\text { the solids was much like all of the previous } \\
\text { segments in color and consistency. }\end{array}$ \\
\hline 9 & $\begin{array}{l}215.18 \\
\text { (solids) }\end{array}$ & 100 & $\begin{array}{l}\text { The sampler was completely full of solids. No } \\
\text { drainable liquids were recovered. Again, the } \\
\text { appearance of the solids was much like all of the } \\
\text { previous samples. }\end{array}$ \\
\hline \multicolumn{4}{|c|}{ Core 46 Wiser 6} \\
\hline 1 & 0 & 0 & $\begin{array}{l}\text { No sample was present in sampler. There were no } \\
\text { drainable liquids. }\end{array}$ \\
\hline 2 & $\begin{array}{c}211.8 \\
\text { (solids) }\end{array}$ & 100 & $\begin{array}{l}\text { The sampler was completely full. No drainable } \\
\text { liquids were recovered. Solids were tan to light } \\
\text { brown in color and had the consistency of "melting } \\
\text { ice cream". The segment was homogeneous in } \\
\text { appearance from top to bottom. }\end{array}$ \\
\hline 3 & $\begin{array}{l}111.88 \\
\text { (solids) }\end{array}$ & 60 & $\begin{array}{l}\text { The sampler was completely full. } 112 \mathrm{~mL} \text { of } \\
\text { solids and } 75 \mathrm{~mL}(51.59 \mathrm{~g}) \text { of drainable liquid } \\
\text { were recovered and the remainder of the sampler } \\
\text { was filled with liquid. The segment was broken in } \\
\text { several places, with NPH filling the voids. The } \\
\text { segment, although broken, was homogeneous in } \\
\text { appearance. The solids were light brown in color } \\
\text { and again had the consistency of "ice cream." }\end{array}$ \\
\hline 4 & $\begin{array}{c}185.78 \\
\text { (solids) } \\
3.08 \\
\text { (liquid) }\end{array}$ & 100 & $\begin{array}{l}\text { The sampler was completely full of solids. } \\
\text { Drainable liquids were recovered, but not enough } \\
\text { to observe characteristics. The color and } \\
\text { consistency of the solids were much like segment } \\
\text { two of this core. }\end{array}$ \\
\hline
\end{tabular}


Table B1-2. Tank 241-T-104 Sample Description. ${ }^{1}$ (3 Sheets)

\begin{tabular}{|c|c|c|c|}
\hline Gegurent & $\begin{array}{l}\text { Weight } \\
(\mathrm{grams})\end{array}$ & $\begin{array}{l}\text { Sample } \\
(\%)\end{array}$ & Spinile Gharadertiles \\
\hline \multicolumn{4}{|c|}{ 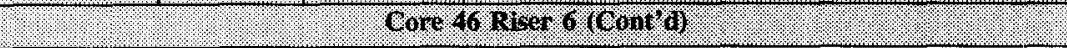 } \\
\hline 5 & $\begin{array}{l}184.59 \\
\text { (solids) }\end{array}$ & 100 & $\begin{array}{l}\text { The sampler was completely full of solids. No } \\
\text { drainable liquids were recovered. Copious } \\
\text { arnounts of NPH saturated the solids. The solids } \\
\text { were light brown in color and had the consistency } \\
\text { of "cold ice cream". The segment was completely } \\
\text { homogenous in appearance from top to bottom. }\end{array}$ \\
\hline 6 & $\begin{array}{r}144.66 \\
\text { (solids) }\end{array}$ & 65 & $\begin{array}{l}122 \mathrm{~mL} \text { of solids were recovered, and about } \\
25 \mathrm{~mL}(18.66 \mathrm{~g}) \text { drainable liquid, which consisted } \\
\text { of mostly NPH. The solids were light brown in } \\
\text { color and had the consistency of "clay". The } \\
\text { segment was homogeneous in appearance with the } \\
\text { exception of variations in NPH content. A tiny } \\
\text { anount of liner liquid was recovered and } \\
\text { discarded. }\end{array}$ \\
\hline 7 & $\begin{array}{c}159.03 \\
\text { (solids) } \\
32.50 \\
\text { (liquid) }\end{array}$ & 98 & $\begin{array}{l}159 \mathrm{~mL} \text { of solids, and } 25 \mathrm{~mL} \text { aqueous liquid were } \\
\text { recovered. The liquid was a murky light brown } \\
\text { color. Solids were very much like segment } 6 \text {, } \\
\text { Core } 46 \text { in appearance (color, consistency, etc.); } \\
\text { however, the solids from this segment appeared } \\
\text { "mushy" at the top end, and became slightly } \\
\text { thicker towards the bottom. }\end{array}$ \\
\hline 8 & $\begin{array}{c}180.1 \\
\text { (solids) }\end{array}$ & 90 & $\begin{array}{l}168 \mathrm{~mL} \text { solids and about } 15 \mathrm{~mL}(13.43 \mathrm{~g}) \\
\text { drainable liquid existing in } 2 \text { phases were } \\
\text { recovered. The drainable liquid was determined to } \\
\text { be primarily NPH. Solids were light brown in } \\
\text { color, and had a "mushy" consistency. }\end{array}$ \\
\hline 9 & $\begin{array}{c}193.3 \\
\text { (solids) }\end{array}$ & 100 & $\begin{array}{l}\text { The sampler was completely full of solids, with no } \\
\text { drainable liquid. The solids were similar (in color } \\
\text { and consistency) to all of the other segments in } \\
\text { Core } 46 \text { and were saturated with NPH. The } \\
\text { segment was homogeneous in appearance. }\end{array}$ \\
\hline
\end{tabular}

Note:

${ }^{1}$ Pool (1994) 


\section{B1.1.3 Sample Analysis}

The analyses performed on the 1992 rotary core samples performed two functions: characterization of the waste in tank 241- -104 , and fulfillment of the requirements of the safety screening DQO. The characterization of the tank waste was performed to support regulatory, safety (waste reactivity) evaluation, performance assessment, waste retrieval and treatment technology development, supplemental environmental impact statement and closure activities (Hill et al. 1991). The analyses required by the safety screening DQO included analyses for thermal properties by DSC, moisture content by TGA, and content of fissile material by total alpha activity analysis. Moisture was also measured by gravimetry as a check on the accuracy of the TGA.

Total alpha activity measurements were performed on samples that had been fused in a solution of potassium hydroxide and then dissolved in acid. The resulting solution was then dried on a counting planchet and counted in an alpha proportional counter. Quality control tests included standards, spikes, blanks, and duplicate analyses.

Ion chromatography (IC) was performed on samples that had been prepared by a water digestion. Quality control tests included standards, spikes, blanks, and duplicate analyses.

Three preparation methods were used for the inductively coupled plasma (ICP) spectrometry analyses: fusion, acid digestion, and a water leach. Quality control tests included standards, blanks, spikes, and duplicate analyses.

All reported analyses were performed in accordance with approved laboratory procedures. A list of the sample numbers and applicable analyses is presented in Table B1-3. The procedure numbers are presented in the discussion in Section B2.0 
Table B1-3. Tank 241-T-104 Sample Analysis Summary. ${ }^{1}$ (3 Sheets)

\begin{tabular}{|c|c|c|c|}
\hline 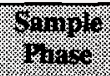 & 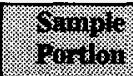 & $\frac{101010}{1010}$ & $401016 \%$ \\
\hline & & & 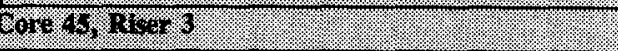 \\
\hline \multirow[t]{20}{*}{ Solid } & \multirow{6}{*}{$\begin{array}{l}\text { Solid } \\
\text { composite }\end{array}$} & $\mathrm{K}-155$ & Gravimetric \\
\hline & & K-157 & Gravimetric \\
\hline & & K-175 & $\begin{array}{l}\text { ICP (acid, fusion, water), IC, GHAA, CVAA, } \\
\text { ammonia, carbonate, cyanide, TGA, pH, TOC, } \\
\text { DSC, nitrite (spec), total U, GEA, total beta, }{ }^{14} \mathrm{C} \text {, } \\
{ }^{129} \mathrm{I},{ }^{3} \mathrm{H},{ }^{237} \mathrm{~Np},{ }^{79} \mathrm{Se},{ }^{90} \mathrm{Sr},{ }^{99} \mathrm{Tc}{ }^{239 / 240} \mathrm{Pu},{ }^{241} \mathrm{Am}\end{array}$ \\
\hline & & $\mathrm{K}-176$ & $\begin{array}{l}\text { ICP (acid, fusion, water), IC, GHAA, CVAA, } \\
\text { ammonia, carbonate, cyanide, TGA, pH, TOC, } \\
\text { DSC, nitrite (spec), total U, GEA, total beta, }{ }^{14} \mathrm{C} \text {, } \\
{ }^{129} \mathrm{I},{ }^{3} \mathrm{H},{ }^{237} \mathrm{~Np},{ }^{79} \mathrm{Se},{ }^{90} \mathrm{Sr},{ }^{99} \mathrm{Tc}{ }^{239 / 240} \mathrm{Pu},{ }^{241} \mathrm{Am}\end{array}$ \\
\hline & & 93-01809 & Total alpha plutonium, weight percent solids, SVOA \\
\hline & & $93-01810$ & Total alpha plutonium, weight percent solids, SVOA \\
\hline & Segment 1 & $93-01790$ & VOA \\
\hline & Segment 2 & 93-01791 & $\begin{array}{l}\text { Weight percent undissolved solid, weight percent } \\
\text { solid }\end{array}$ \\
\hline & Segment 3 & $\overline{93-01792}$ & VOA \\
\hline & Segment 4 & $93-01793$ & $\begin{array}{l}\text { Weight percent undissolved solid, weight percent } \\
\text { solid }\end{array}$ \\
\hline & Segment 5 & $93-01794$ & VOA \\
\hline & Segment 6 & $93-01795$ & $\begin{array}{l}\text { Weight percent undissolved solid, weight percent } \\
\text { solid }\end{array}$ \\
\hline & Segment 7 & $93-01796$ & VOA \\
\hline & Segment 8 & 93-01797 & $\begin{array}{l}\text { Weight percent undissolved solid, weight percent } \\
\text { solid }\end{array}$ \\
\hline & Segment 9 & 93-01798 & VOA \\
\hline & \multirow[t]{5}{*}{ Segment 9} & 93-01807 & Total alpha plutonium \\
\hline & & $93-01808$ & Total alpha plutonium \\
\hline & & K-189 & Total uranium \\
\hline & & K-196 & TCLP (CVAA, ICP) \\
\hline & & K-199 & TCLP (ICP) \\
\hline
\end{tabular}


Table B1-3. Tank 241-T-104 Sample Analysis Summary. ${ }^{1}$ (3 Sheets)

\begin{tabular}{|c|c|c|c|}
\hline Sample & rangule & Sample & 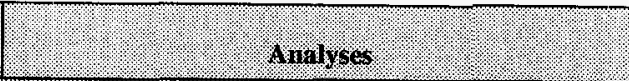 \\
\hline \multicolumn{4}{|c|}{ 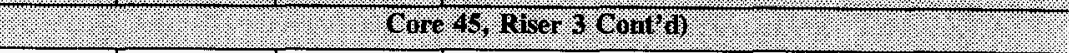 } \\
\hline \multirow[t]{2}{*}{ Solid } & $\begin{array}{l}\text { Segments } \\
1,2,3,4 \\
5,6,7,8 \\
9\end{array}$ & $\begin{array}{l}\mathbf{K}-67,68 \\
69,70,71 \\
72,74,75 \\
76,77,78 \\
79,81,82 \\
83,84,85 \\
86\end{array}$ & TGA, DSC \\
\hline & $\begin{array}{l}\text { Segments } \\
2,3,4,5 \\
6,7,8,9\end{array}$ & $\begin{array}{l}\mathrm{K}-25,27 \\
29,33,35 \\
37,39,42\end{array}$ & Gravimetric \\
\hline \multicolumn{4}{|r|}{ Core. 46. Riser. 6} \\
\hline Liquid & $\begin{array}{l}\text { Liquid } \\
\text { composite } \\
\text { (consisted } \\
\text { of liquid } \\
\text { from seg. } 7 \\
\text { only) }\end{array}$ & $\mathrm{K}-204$ & $\begin{array}{l}\text { ICP (acid, fusion, water), IC, cyanide, GEA, alpha } \\
\text { spectrometry, TOC, }{ }^{238} \mathrm{Pu},{ }^{239 / 240} \mathrm{Pu}, \mathrm{TGA}, \mathrm{pH}, \mathrm{TOC} \text {, } \\
\text { specific gravity }\end{array}$ \\
\hline \multirow[t]{9}{*}{ Solid } & \multirow{6}{*}{$\begin{array}{l}\text { Solid } \\
\text { composite }\end{array}$} & K-159 & Gravimetric \\
\hline & & K-161 & Gravimetric \\
\hline & & $\mathrm{K}-179$ & $\begin{array}{l}\text { ICP (acid, fusion, water), IC, GHAA, CVAA, } \\
\text { ammonia, carbonate, cyanide, TGA, pH, TOC, } \\
\text { DSC, total U, GEA, total beta, }{ }^{14} \mathrm{C},{ }^{129} \mathrm{I},{ }^{3} \mathrm{H},{ }^{237} \mathrm{~Np} \text {, } \\
{ }^{79} \mathrm{Se},{ }^{90} \mathrm{Sr},{ }^{99} \mathrm{Tc},{ }^{239 / 240} \mathrm{Pu},{ }^{241} \mathrm{Am}\end{array}$ \\
\hline & & K-180 & $\begin{array}{l}\text { ICP (acid, fusion, water), IC, GHAA, CVAA, } \\
\text { ammonia, carbonate, cyanide, TGA, pH, TOC, } \\
\text { DSC, total U, GEA, total beta, }{ }^{14} \mathrm{C},{ }^{129} \mathrm{I},{ }^{3} \mathrm{H},{ }^{237} \mathrm{~Np} \text {, } \\
{ }^{79} \mathrm{Se},{ }^{90} \mathrm{Sr},{ }^{99} \mathrm{Tc},{ }^{239}{ }^{240} \mathrm{Pu},{ }^{241} \mathrm{Am}\end{array}$ \\
\hline & & 93-01811 & Total alpha plutonium, SVOA \\
\hline & & $93-01812$ & Total alpha plutonium, weight percent solids, SVOA \\
\hline & \multirow[t]{3}{*}{ Segment 2} & 93-01799 & VOA \\
\hline & & $\mathrm{K}-146$ & ICP (acid), GEA, total alpha \\
\hline & & $\mathrm{K}-147$ & ICP (acid), GEA, total alpha \\
\hline
\end{tabular}


Table B1-3. Tank 241-T-104 Sample Analysis Summary. ${ }^{1}$ (3 Sheets)

\begin{tabular}{|c|c|c|c|}
\hline Sample & Sornole & Yample & Antarses \\
\hline \multicolumn{4}{|c|}{ Cone 4 f. niver 6 ( (antr) } \\
\hline \multirow[t]{9}{*}{ Solid } & Segment 3 & $93-01801$ & VOA \\
\hline & Segment 4 & 93-01800 & VOA \\
\hline & Segment 5 & $93-01802$ & VOA \\
\hline & Segment 6 & 93-01803 & VOA \\
\hline & Segment 7 & 93-01804 & VOA \\
\hline & Segment 8 & $93-01805$ & VOA \\
\hline & Segment 9 & $93-01806$ & VOA \\
\hline & $\begin{array}{l}\text { Segments } \\
2,3,4,5 \\
6,7,8,9\end{array}$ & $\begin{array}{l}\mathrm{K}-90,91, \\
92,93,95, \\
96,97,98, \\
99,100, \\
102,103 \\
104,105 \\
106,107\end{array}$ & TGA, DSC \\
\hline & $\begin{array}{l}\text { Segments } \\
2,3,4,5 \\
6,7,8,9\end{array}$ & $\begin{array}{l}\mathrm{K}-46,48 \\
53,55,57 \\
59,62,64\end{array}$ & Gravimetric \\
\hline
\end{tabular}

Notes:

$\begin{array}{lll}\text { CVAA } & = & \text { cold vapor atomic absorption } \\ \text { DSC } & \text { differential scanning calorimetry } \\ \text { GEA } & = & \text { gamma energy analysis } \\ \text { GHAA } & = & \text { graphite hydride atomic absorption } \\ \text { IC } & = & \text { ion chromatography } \\ \text { ICP } & = & \text { inductively coupled plasma } \\ \text { SVOA } & = & \text { semi-volatile organic analysis } \\ \text { TCLP } & = & \text { toxic characteristic leach procedure } \\ \text { TGA } & = & \text { thermogravimetric analysis } \\ \text { TOC }= & \text { total organic carbon } \\ \text { VOA }= & \text { volatile organic analysis }\end{array}$

${ }^{1}$ Pool (1994) 


\section{B1.2 VAPOR PHASE MEASUREMENTS}

Vapor phase measurements were made on tank 241-T-104 in February 1996 as part of a riser preparation procedure (WHC 1996). Measurements were made for flammability, total organic carbon, oxygen, and ammonia at the riser 8 breather vent, within riser 8 , and in the tank headspace beneath riser 8 .

\section{B1.3 DESCRIPTION OF HISTORICAL SAMPLING EVENT}

Sampling data for tank 241-T-104 have been obtained for one core of nine segments, the results of which were reported in Horton (1979). The data are presented in Section B2.6. Pre-1989 analytical data have not been validated and should be used with caution. No information was available on the riser used for this core sampling event.

The segments appeared uniform in color, with a light brown color interspersed with reddish-brown flecks. The segments exhibited the consistency of soft putty, with the exception of segment nine, which contained a small amount of hard, gravel-like material. No stratification of aluminum compounds was apparent. The samples were subjected to a water leach, which resulted in water-soluble and water-insoluble fractions. These fractions were analyzed. Horton (1979) does not specify the method used to prepare the water-insoluble fraction for analysis, but it was probably a caustic fusion or acid digestion.

\section{B2.0 ANALYTICAL RESULTS}

\section{B2.1 OVERVIEW}

This section summarizes the sampling and analytical results associated with the August 1992 sampling and analysis of tank 241-T-104 as well as the results of the 1996 vapor measurements and the historical sampling event. The results of the analyses required by the safety screening DQO (total alpha activity, percent water, energetics, and density) are presented first, followed by the remaining characterization analyses, as listed in Table B2-1. The results of the 1992 core sampling event are documented in Pool (1994). Section B2.11 contains all analytical data tables. 
Table B2-1. Analytical Presentation Tables.

\begin{tabular}{|c|c|}
\hline (1) Naris & 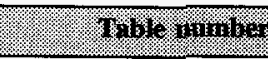 \\
\hline Total alpha activity & B2-2 \\
\hline Percent water & B2-3 \\
\hline Differential scanning calorimetry & Section B2.3.2 \\
\hline Physical, chemical and radiochemical analytical data & B2-4 through B2-92 \\
\hline Vapor measurements & B2-93 \\
\hline Historical sampling results & $\mathrm{B} 2-94$ and $\mathrm{B} 2-95$ \\
\hline
\end{tabular}

\section{B2.2 TOTAL ALPHA ACTIVITY}

Analyses for total alpha activity were performed on the samples recovered from tank 241-T-104. The samples were prepared by fusion digestion per procedure LA-549-141 and analyzed according to procedure LA-508-101. Two fusions were prepared per sample (for duplicate results). Each fused dilution was analyzed twice, and the results were averaged and reported as one value. The highest result returned was $0.121 \mu \mathrm{Ci} / \mathrm{g}$. The sample results for total alpha are given in Table B2-2.

\section{B2.3 THERMODYNAMIC ANALYSES}

As required by the safety screening DQO, TGA and DSC were performed on the solids. Other physical tests performed included density of the sludge and of the centrifuged solids and supernatant, percent settled solids, volume and weight percent centrifuged solids, weight percent undissolved solids, and specific gravity of the one aqueous drainable liquid sample.

\section{B2.3.1 Thermogravimetric Analysis}

Thermogravimetric analysis measures the mass of a sample while its temperature is increased at a constant rate. Nitrogen is passed over the sample during heating to remove any released gases. Any decrease in the weight of a sample during TGA represents a loss of gaseous matter from the sample, either through evaporation or through a reaction that forms gas phase products. The moisture content is estimated by assuming that all TGA sample weight loss up to a certain temperature (typically 150 to $200^{\circ} \mathrm{C}$ [ 300 to $\left.390^{\circ} \mathrm{F}\right]$ ) is due to water evaporation. The temperature limit for moisture loss is chosen by the operator at an inflection point on the TGA plot. Other volatile matter fractions can often be differentiated by inflection points as well. 
Tank 241-T-104 unhomogenized samples were analyzed directly by TGA using procedure LA-560-112 on a Mettler TG 50 instrument. The results varied from 41 to 69 weight percent on core 45 (with one exception) and between 52 and 76 weight percent on core 46 . The TGA analyses were not initially run in duplicate because of time constraints. The duplicates were run at a later date. There was good agreement between primary and duplicate samples with the exception of sample K67 (core 45 segment 1) which exhibited a 29 percent RPD. The rerun was performed 79 days later. The original sample displayed moisture content of 47 weight percent; the rerun displayed 9.6 weight percent water. The difference was determined to be because of drying. Gravimetric analyses were performed on the 241-T-104 subsamples from this tank to assess the accuracy of the TGA results. The gravimetric analyses were thought to be more reliable than the TGA analyses because of the larger sample sizes and the resultant decrease in sensitivity to waste heterogeneity. Weight percent water by gravimetry varied from 63.9 to 72.5 weight percent for core 45 , and from 64.5 to 74.7 weight percent for core 46 . The TGA and gravimetric results are presented in Table B2-3.

\section{B2.3.2 Differential Scanning Calorimetry}

In a DSC analysis, heat absorbed or emitted by a substance is measured while the temperature of the sample is heated at a constant rate. Nitrogen is passed over the sample material to remove any gases being released. The onset temperature for an endothermic or exothermic event is determined graphically.

The DSC analyses for tank 241-T-104 were performed on whole segments and composites using procedure LA-560-112. No exothermic reactions were noted, and none of the DSC thermograms were integrated. Therefore, an upper limit of a 95 percent confidence interval on the mean for each sample was not calculated.

\section{B2.4 PHYSICAL PROPERTIES}

\section{B2.4.1 Density and Percent Solids}

The density measurements were carried out on the liquid and solid samples. The mean liquid density was $1.13 \mathrm{~g} / \mathrm{mL}$ and the mean solid density was $1.29 \mathrm{~g} / \mathrm{mL}$. Percent solids were measured as volume percent and as weight percent, on settled solids and on centrifuged solids. Four different segments from core 45 , numbers $2,4,6$ and 8 , were analyzed. The segment 2 sample was observed to be very different from the segment 4,6 , and 8 samples in that the weight percent solids result for segment two was 1.5 times the weight percent solids observed in the other 3 segments. The undissolved solids were calculated by subtracting the percentage of dissolved solids from the weight percent total solids. The results for 
segments 4, 6, and 8 were similar, as shown in Table B2-4. Note also that the centrifuged solids and bulk sample densities were in contrast between segment 2 and segments 4, 6, and 8. Procedure PNL-ALO-504 was used to measure the weight percent solids.

Rough density estimates were made for each segment and drainable liquid sample by dividing the weight of the solids or drainable liquid recovered from each segment by its estimated volume. However, because of the large uncertainties associated with estimating the volumes, results varied widely.

\section{B2.4.2 Particle Size}

Particle size analyses are performed by passing a laser beam through a sample that has been suspended in a dispersant. The amount of light attenuated by the particles is a measure of the size and number of the particles in the sample. The particle size analyzer has a range of 0.5 to $150 \mu \mathrm{m}$, and is set up to give the short diameter of the particle, irrespective of the particle's shape. From these data, the number and volume probability densities are calculated. The number probability density is an indication of the average size of the particles based on the number of particles measured, whereas the volume probability density is an indication of the size of the particles that occupy most of the sample volume. A small difference between the number probability density and the volume probability density is an indication of relative uniformity of particle size; conversely, a large difference indicates that most of the sample volume is occupied by a few large particles and the remaining volume is occupied by many small particles. Table B2-6 lists the particle size analyses results, along with standard deviations. For all segments, a relatively large difference exists between the number and the volume probability densities. This shows a large range of particle size in the sample.

The chemical properties of the dispersant are vital to the particle size test in that the particles can be dissolved or additional particles can be precipitated in the dispersant, thereby changing their size or number. Drainable liquid, or 'mother liquor', is a suitable choice because it is in chemical equilibrium with the solid portion of the waste, and will neither precipitate the solids nor dissolve them. In the case of tank 241-T-104, water was used as the matrix. The choice to use water may have been made because the waste was relatively insoluble, and any error would likely be small.

Inspection of the tank 241-T-104 particle size data shows no discernable trends in the vertical variation of the data.

\section{B2.4.3 Rheology}

The shear strength of segments 2, 4, 6 and 8 was measured from core 45 . Table B2-7 shows the shear strength of each segment. 
Shear stress measurements were also made on the dilutions of segment samples at ambient temperature and $95^{\circ} \mathrm{C}\left(203{ }^{\circ} \mathrm{F}\right)$. The water:sample $1: 1$ dilution at both temperatures exhibited yield pseudoplastic behavior, although segments 4,6 and 8 had low yield points of $<0.2 \mathrm{~Pa}$ and segment 2 had a yield point of $1 \mathrm{~Pa}$. The viscosity of the sample decreased as the temperature was increased. The 3:1 dilutions for all segments exhibited Newtonian behavior.

\section{B2.5 INORGANIC ANALYSES}

Inductively coupled plasma spectroscopy was performed on the 1992 core samples to measure the concentrations of metals. Ion chromatography was used to measure the concentrations of anions. The concentration of each analyte is present in tables at the end of Section B2. The discussion accompanying each analytical method includes the digestion method, the analytical method, and comments about any problems with the analysis.

In each table, the "Mean" column is the average of the result and duplicate values. All values, including those below the detection level (denoted by the less-than symbol, "<"), were averaged. If both sample and duplicate values were non-detected, the mean is expressed as a non-detected value. If one value was detected while the other was not, the mean is expressed as a non-detected value. If both values were detected, the mean is expressed as a detected value.

\section{B2.5.1 Inductively Coupled Plasma}

The ICP analyses were performed per procedure LA-505-151 and were prepared by water, fusion, and acid digests. The concentrations of metals in the samples as measured by ICP are shown in Tables B2-8 through B2-38. The results from three preparation methods, water, fusion, and acid, are presented for the metals. Composite samples were prepared by acid digestion prior to analysis. Other samples were prepared by fusion with potassium hydroxide in a nickel crucible, or by a water leach. The nickel results for the ICP fusion analyses are biased high, because the samples were prepared in a nickel crucible by fusion using potassium hydroxide.

\section{B2.5.2 Ion Chromatography}

Samples for ion chromatography (IC) were prepared by water digestion and performed in duplicate per procedure LA-533-105. The concentrations of anions by IC are shown in Tables B2-39 through B2-44. Only water soluble anions could be measured. The presence and concentration of insoluble anions can be inferred from the ICP data in some cases (i.e., phosphate and sulfate). 


\section{B2.5.3 Total Uranium}

Total uranium was measured on composites from both cores and on a segment from each core by laser phosphorescence, using procedure number LA-925-106. Results for the total uranium analysis are found in Table B2-45.

\section{B2.5.4 Arsenic, Selenium, and Mercury by Atomic Absorption Spectroscopy}

Arsenic and selenium were measured by gaseous hydride atomic absorption spectroscopy using procedure number LA-355-131. Mercury was measured by cold vapor atomic absorption spectroscopy using procedure number LA-325-104. In addition to measuring the concentrations of the metals in the tank waste, a toxic characteristic leaching profile test was used to measure the metals for their tendency to precipitate in or absorb on a sample container in a matrix with $\mathrm{pH}$ greater than 2. The concentrations of arsenic, selenium, and mercury as determined by atomic absorption spectroscopy may be found in Tables B2-46, B2-47, and B2-48.

\section{B2.5.5 Ammonia}

Ammonia was measured using the Kjeldahl method, procedure number LA-634-102. The ammonia concentration was measured on composites from both cores. The results were all less than the detection limit. Ammonia concentrations may be found in Table B2-49.

\section{B2.5.6 Cyanide by Distillation and Spectroscopy}

Cyanide was measured by a process of distillation and spectroscopy, using procedure number LA-695-102. Analytical results are presented in Table B2-50.

\section{B2.5.7 Nitrite by Spectrophotometry}

Nitrite was measured by spectrophotometry as a back-up for the IC analysis. Analytical results are presented in Table B2-51.

\section{B2.5.8 pH}

pH was measured using a pH electrode. Analytical results are presented in Table B2-52. 


\section{B2.6 ORGANIC ANALYSES}

\section{B2.6.1 Semivolatile and Volatile Organic Analysis}

Semivolatile organic analysis (SVOA) was performed on the tank waste samples using procedure number PNL-ALO-344/345. Samples were extracted using procedure PNL-ALO-120, and were cleaned of hydrocarbons prior to analysis by procedure number PNL-ALO-122. Volatile organic analysis (VOA) was performed using procedure PNL-ALO-335 after being cleaned of hydrocarbons (mostly normal paraffin hydrocarbon) by procedure number PNL-ALO-121. Both semivolatile and volatile organic compounds were analyzed by gas chromatography/mass spectroscopy. Results for the SVOA analysis are presented in Tables B2-53 through B2-58. Those for the VOA analysis are presented in Tables B2-59 through B2-65.

\section{B2.7 TOTAL INORGANIC AND ORGANIC CARBON}

Total inorganic carbon (TIC) was measured using procedure number LA-344-105. Total organic carbon (TOC) was measured using procedure number LA-622-102. Analytical results for TIC and TOC may be found in Tables B2-66 and B2-67, respectively.

\section{B2.8 RADIONUCLIDES}

\section{B2.8.1 Fission Products by Gamma Energy Analysis}

Gamma energy analysis (GEA) was used to measure the activities of ${ }^{241} \mathrm{Am},{ }^{137} \mathrm{Cs},{ }^{60} \mathrm{Co}$, ${ }^{154} \mathrm{Eu}$, and ${ }^{155} \mathrm{Eu}$, using procedure number LA-548-121. The samples were prepared by a fusion digestion method. Analytical results are presented in Tables B2-68, B2-69, B2-70, $\mathrm{B} 2-71$, and $\mathrm{B} 2-72$, respectively. ${ }^{129} \mathrm{I}$ was measured by gamma counting using procedure number LA-378-103. The results are presented in Table B2-73.

\section{B2.8.2 Fission Products by Separation and Counting}

Liquid scintillation and counting were used to measure the activities of ${ }^{14} \mathrm{C},{ }^{3} \mathrm{H},{ }^{79} \mathrm{Se}$, and ${ }^{99} \mathrm{Tc}$. The respective procedure numbers are LA-348-104, LA-218-113, LA-365-132, and LA-438-101. ${ }^{3} \mathrm{H}$ and ${ }^{14} \mathrm{C}$ were prepared for analysis using a water digestion; ${ }^{79} \mathrm{Se}$ and $99 \mathrm{Tc}$ were prepared using a fusion digestion. The analytical results for ${ }^{14} \mathrm{C},{ }^{3} \mathrm{H},{ }^{79} \mathrm{Se}$, and ${ }^{99} \mathrm{Tc}$ are presented in Tables B2-74, B2-75, B2-76, and B2-77, respectively. ${ }^{90} \mathrm{Sr}$ was prepared for 
analysis using a fusion digestion method, and was counted on a beta proportional counter. The procedure number for the ${ }^{90} \mathrm{Sr}$ analysis was LA-220-101, and the results are presented in Table B2-78.

\section{B2.8.3 Total Beta Activities by Proportional Counting}

Total beta activities are the measurements of the gross beta activities of the waste samples. The samples were prepared by a fusion digestion and were counted using procedure number LA-508-101. The results are presented in Tables B2-79.

\section{B2.8.4 Transuranic Radionuclides by Separation and Counting}

${ }^{241} \mathrm{Am},{ }^{238} \mathrm{Pu}$, and ${ }^{239 / 240} \mathrm{Pu}$ were measured by alpha spectrometry on a fusion digested sample, procedure number LA-503-156 and presented in Tables B2-80, B2-81, and B2-82, respectively. ${ }^{237} \mathrm{~Np}$ was measured after chemical separation by alpha proportional counting using procedure number LA-933-141, and the results of the analyses are presented in Table B2-83. Plutonium/uranium mass spectrometry was performed on a fusion digested sample using procedure number PNL 2.30.6. Results are presented in Tables B2-84 through B2-92.

\section{B2.9 VAPOR PHASE MEASUREMENT}

The vapor headspace of tank 241-T-104 was not evaluated for flammability when the 1992 core samples were taken. Vapor samples were, however, taken in February of 1996 as part of a riser preparation procedure (WHC 1996). The results are presented in Table B2-93.

\section{B2.10 HISTORICAL SAMPLING RESULTS}

An internal letter (Horton 1979) reported the results of the analysis of a nine-segment core from tank 241-T-104. The samples were taken after the tank was removed from service. The principal difference between the 1979 analytical results and those from the 1992 samples is probably the water content of the waste. The only activity the tank has undergone since it. was placed out of service is saltwell pumping. The analytical results of the 1979 sample and analysis event are presented in Tables B2-94 and B2-95. The waste was described as having a light yellow color, interspersed with reddish-brown flecks. The samples exhibited a uniform putty-like texture, with the exception of segment 9 , which contained a small amount of hard, gravel-like material. 


\section{B2.11 ANALYTICAL DATA TABLES}

The quality control (QC) parameters assessed in conjunction with the tank 241-T-104 samples are listed below. The QC criteria were specified in Appendix D of the waste characterization plan (Hill et al. 1991). The criterion for matrix spikes was 75 to 125 percent recovery. Other QC criteria were established according to the analysis, the waste constituent, and the histories of the QC criteria. The relative percent difference (RPD) was used as a measure of precision. The RPD is defined as the absolute value of the difference between the sample and duplicate, divided by the average of the sample and duplicate, and multiplied by 100 percent. Sample and duplicate pairs in which any of the QC parameters did not meet the requirements are footnoted in the sample mean column of the data summary tables. The specific QC notations are defined in the following lists:

For non-radioactive constituents (other than VOA and SVOA):

1. Chain of custody

2. Holding times

3. Instrument calibration

4. Initial and continuing calibration verification

5. Analytical blanks

6. Preparation blanks

7. Interference check sample

8. Laboratory check sample

9. Duplicate analysis

10. Matrix spike or post-digestion spike

11. Retention time

12. Contract required detection limit

13. Serial dilution 
For radioactive constituents:

1. Chain of custody

2. Instrument calibration

3. Efficiency checks

4. Background checks

5. Preparation blanks

6. Laboratory control sample

7. Duplicate analysis

8. Matrix spike/tracers/surrogates

For VOA and semi-VOA constituents:

1. Holding times

2. Surrogate recovery

3. Matrix spike/matrix spike duplicate

4. Blanks

5. gas chromatograph/mass spectrometer tune

6. Calibration

7. Internal standards

8. Instrument performance. 
HNF-SD-WM-ER-372 Rev. 1

Table B2-2. Tank 241-T-104 Analytical Results: Total Alpha (Alpha).

\begin{tabular}{|c|c|c|c|c|c|}
\hline 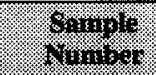 & 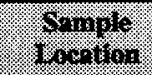 & 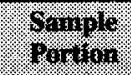 & 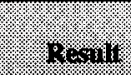 & (1) & 1/2.11. \\
\hline \multicolumn{3}{|c|}{ 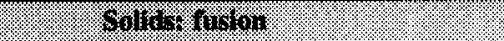 } & $4 \%$ & $4 x_{3}$ & 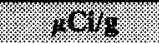 \\
\hline 93-1807-H1 & \multirow[t]{2}{*}{$45: 9$} & WHOLE & 0.111 & 0.108 & $0.1095^{\mathrm{QC}: 2,4,8}$ \\
\hline 93-1808-H1 & & WHOLE & 0.0803 & 0.0743 & $0.0773^{\mathrm{QC}: 2,4,8}$ \\
\hline 146 & \multirow[t]{2}{*}{$46: 2$} & WHOLE & 0.197 & 0.217 & 0.207 \\
\hline 146 & & WHOLE & 0.211 & 0.196 & 0.2035 \\
\hline 93-1809-H1 & \multirow[t]{2}{*}{$\begin{array}{l}\text { Core } 45 \\
\text { Composite }\end{array}$} & WHOLE & 0.155 & 0.16 & $0.1575^{Q C: 2,4,8}$ \\
\hline 93-1810-H1 & & WHOLE & 0.155 & 0.0151 & $0.153^{\mathrm{QC}: 2,4,8}$ \\
\hline 93-1811-H1 & \multirow[t]{2}{*}{$\begin{array}{l}\text { Core } 46 \\
\text { Composite }\end{array}$} & WHOLE & 0.155 & 0.156 & $0.1555^{\mathrm{QC}: 2,4,8}$ \\
\hline 93-1812-H1 & & WHOLE & 0.16 & 0.144 & $0.152^{\mathrm{QC}: 2,4,8}$ \\
\hline 175 & \multirow[t]{2}{*}{$\begin{array}{l}\text { Core } 45 \\
\text { Composite }\end{array}$} & WHOLE & 0.101 & 0.103 & $0.102^{Q C: 2,4,8}$ \\
\hline 176 & & WHOLE & 0.106 & 0.107 & $0.1065^{\mathrm{QC}: 2,4,8}$ \\
\hline 179 & \multirow[t]{2}{*}{$\begin{array}{l}\text { Core } 46 \\
\text { Composite }\end{array}$} & WHOLE & 0.115 & 0.121 & 0.118 \\
\hline 180 & & WHOLE & 0.11 & 0.109 & 0.1095 \\
\hline
\end{tabular}


HNF-SD-WM-ER-372 Rev. 1

Table B2-3. Percent Water by TGA and Gravimetric Analysis. ${ }^{1}$ (4 Sheets)

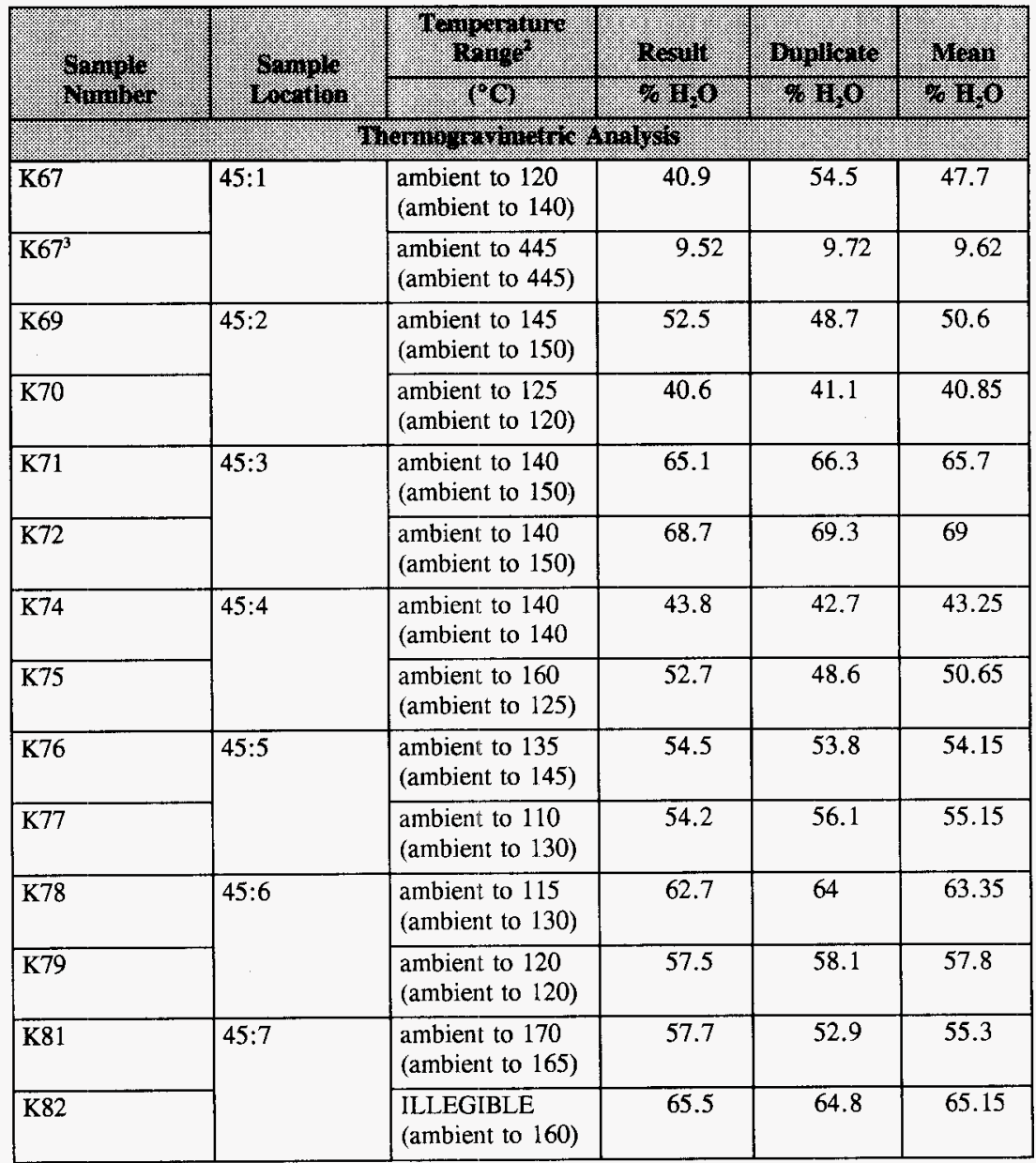


HNF-SD-WM-ER-372 Rev. 1

Table B2-3. Percent Water by TGA and Gravimetric Analysis. ${ }^{1}$ (4 Sheets)

\begin{tabular}{|c|c|c|c|c|c|}
\hline 纤. & 1601101 & Tempromo & 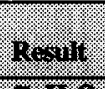 & 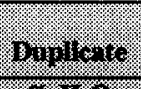 & $\% 1$ \\
\hline (2) & 40.0141 & (2. & \% & 1. & 6. : 16) \\
\hline \multicolumn{6}{|c|}{ 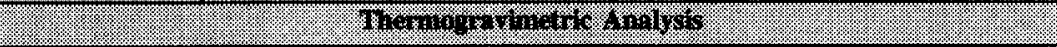 } \\
\hline $\mathrm{K} 83$ & \multirow[t]{2}{*}{$45: 8$} & $\begin{array}{l}\text { ambient to } 180 \\
\text { (ambient to } 180 \text { ) }\end{array}$ & 59.6 & 60.2 & 59.9 \\
\hline $\bar{K} 84$ & & $\begin{array}{l}\text { ambient to } 190 \\
\text { (ambient to } 190 \text { ) }\end{array}$ & 60.5 & 62.5 & 61.5 \\
\hline K85 & \multirow[t]{2}{*}{$45: 9$} & $\begin{array}{l}\text { ambient to } 185 \\
\text { (ambient to } 185 \text { ) }\end{array}$ & 64.2 & 64.9 & 64.55 \\
\hline K86 & & $\begin{array}{l}\text { ambient to } 195 \\
\text { (ambient to 195) }\end{array}$ & 66.9 & 63.6 & 65.25 \\
\hline K90 & \multirow[t]{2}{*}{$46: 2$} & $\begin{array}{l}\text { ambient to } 185 \\
\text { (ambient to } 190 \text { ) }\end{array}$ & 62.5 & 58.9 & 60.7 \\
\hline K91 & & $\begin{array}{l}\text { ambient to } 180 \\
\text { (ambient to } 190 \text { ) }\end{array}$ & 60.7 & 55.4 & 58.05 \\
\hline K92 & \multirow[t]{2}{*}{$46: 3$} & $\begin{array}{l}\text { ambient to } 275 \\
\text { (ambient to } 180 \text { ) }\end{array}$ & 68.1 & 61.6 & 64.85 \\
\hline K93 & & $\begin{array}{l}\text { ambient to } 110 \\
\text { (ambient to } 110 \text { ) }\end{array}$ & 60.2 & 57.2 & 58.7 \\
\hline K95 & \multirow[t]{2}{*}{$46: 4$} & $\begin{array}{l}\text { ambient to } 135 \\
\text { (ambient to } 130 \text { ) }\end{array}$ & 68.3 & 73.62 & 70.96 \\
\hline K96 & & $\begin{array}{l}\text { ambient to } 145 \\
\text { (ambient to } 140 \text { ) }\end{array}$ & 68.8 & 67.4 & 68.1 \\
\hline K97 & \multirow[t]{2}{*}{$46: 5$} & $\begin{array}{l}\text { ambient to } 130 \\
\text { (ambient to } 130 \text { ) }\end{array}$ & 73.1 & 76.3 & 74.7 \\
\hline K98 & & $\begin{array}{l}\text { ambient to } 135 \\
\text { (ambient to } 285 \text { ) }\end{array}$ & 66.4 & 69.4 & 67.9 \\
\hline $\bar{K} 100$ & \multirow[t]{2}{*}{$46: 6$} & $\begin{array}{l}\text { ambient to } 140 \\
\text { (ambient to } 125 \text { ) }\end{array}$ & 68.9 & 67 & 67.95 \\
\hline K99 & & $\begin{array}{l}\text { ambient to } 125 \\
\text { (ambient to } 125 \text { ) }\end{array}$ & 51.6 & 53.7 & 52.65 \\
\hline
\end{tabular}


HNF-SD-WM-ER-372 Rev. 1

Table B2-3. Percent Water by TGA and Gravimetric Analysis. ${ }^{1}$ (4 Sheets)

\begin{tabular}{|c|c|c|c|c|c|}
\hline \multirow{2}{*}{ Sarnole } & \multirow{2}{*}{ arangle: } & 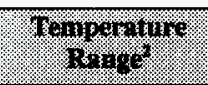 & Resial: & I & 1rain \\
\hline & & 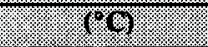 & 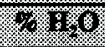 & 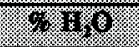 & 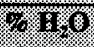 \\
\hline . & \multicolumn{4}{|c|}{ 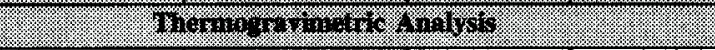 } & \\
\hline K102 & \multirow[t]{2}{*}{$46: 7$} & $\begin{array}{l}\text { ambient to } 110 \\
\text { (ambient to } 125 \text { ) }\end{array}$ & 61 & 63.6 & 62.3 \\
\hline K103 & & $\begin{array}{l}\text { ambient to } 145 \\
\text { (ambient to } 105 \text { ) }\end{array}$ & 65.1 & 62.6 & $\overline{63.85}$ \\
\hline K104 & \multirow[t]{2}{*}{$46: 8$} & $\begin{array}{l}\text { ambient to } 155 \\
\text { (ambient to } 155 \text { ) }\end{array}$ & 59.7 & 70.6 & 65.15 \\
\hline K105 & & $\begin{array}{l}\text { ambient to } 155 \\
\text { (ambient to } 140 \text { ) }\end{array}$ & 68.4 & 67.6 & 68 \\
\hline K106 & \multirow[t]{2}{*}{$46: 9$} & $\begin{array}{l}\text { ambient to } 175 \\
\text { (ambient to } 190 \text { ) }\end{array}$ & 61.9 & 60.4 & 61.15 \\
\hline K107 & & $\begin{array}{l}\text { ambient to } 200 \\
\text { (ambient to } 140 \text { ) }\end{array}$ & 70.1 & 69.9 & 70 \\
\hline K175 & \multirow[t]{2}{*}{$\begin{array}{l}\text { Core } 45 \\
\text { composite }\end{array}$} & $\begin{array}{l}\text { ambient to } 155 \\
\text { (ambient to } 115 \text { ) }\end{array}$ & 67 & 67.2 & 67.1 \\
\hline K176 & & $\begin{array}{l}\text { ambient to } 145 \\
\text { (ambient to } 145 \text { ) }\end{array}$ & 70.6 & 68.5 & 69.55 \\
\hline K179 & \multirow[t]{2}{*}{$\begin{array}{l}\text { Core } 46 \\
\text { composite }\end{array}$} & $\begin{array}{l}\text { ambient to } 140 \\
\text { (ambient to } 125 \text { ) }\end{array}$ & 63.9 & 64.4 & 64.15 \\
\hline K180 & & $\begin{array}{l}\text { ambient to } 135 \\
\text { (ambient to } 150 \text { ) }\end{array}$ & 68.8 & 70.3 & 69.55 \\
\hline K204 & $\begin{array}{l}\text { Drainable } \\
\text { liquid } \\
\text { composite }\end{array}$ & (ambient to 125) & $\overline{83.4}$ & 83.7 & 83.55 \\
\hline
\end{tabular}


HNF-SD-WM-ER-372 Rev. 1

Table B2-3. Percent Water by TGA and Gravimetric Analysis. ${ }^{1}$ (4 Sheets)

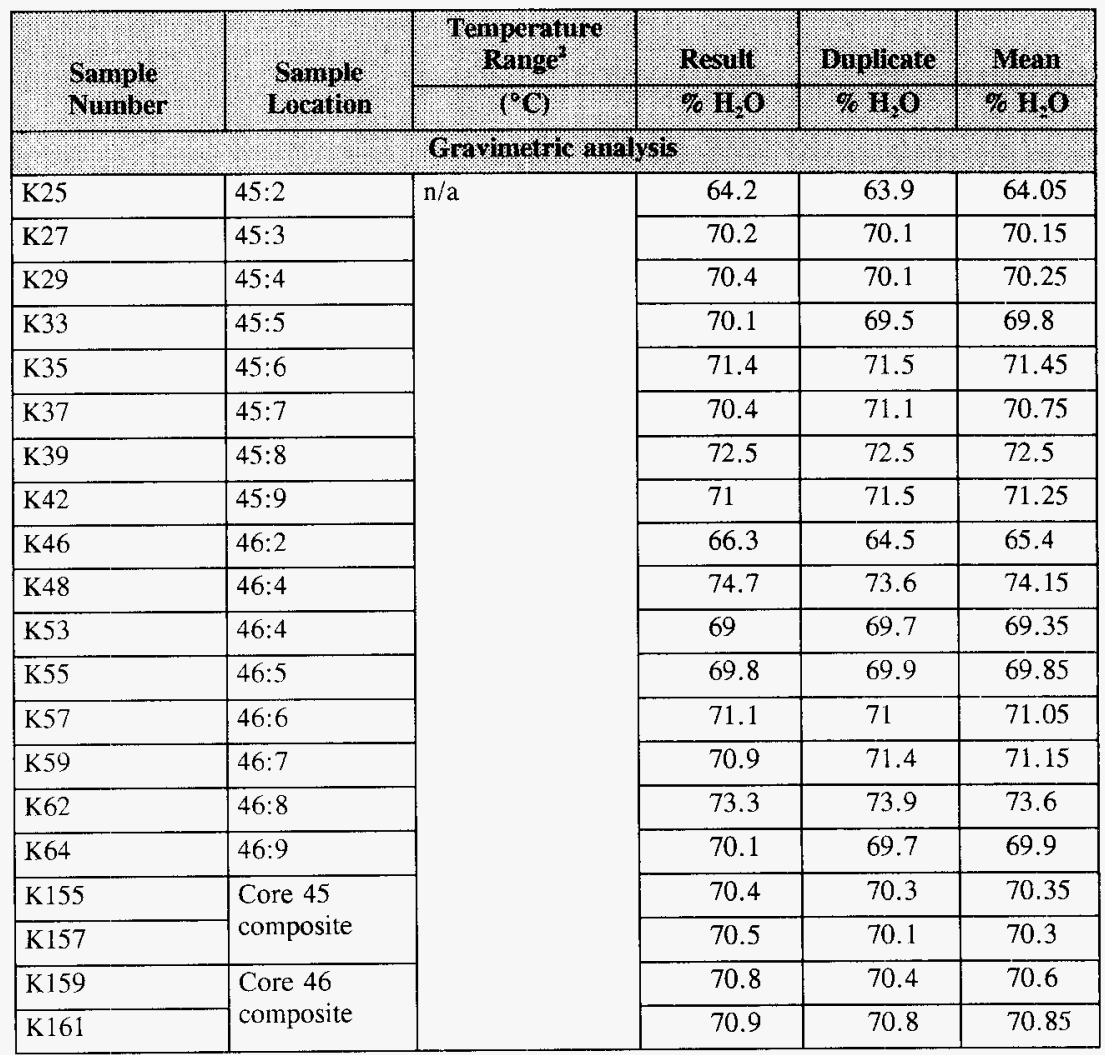

Notes:

$\mathrm{n} / \mathrm{a}=$ not applicable

${ }^{3}$ Pool (1994)

${ }^{2}$ Temperature ranges in parentheses are for the duplicate.

${ }^{3}$ Rerun performed approximately 10 weeks after original analysis. Sample had lost moisture through evaporation. 
Table B2-4. Tank 241-T-104 Core 45 Physical Measurements.

\begin{tabular}{|c|c|c|c|c|c|}
\hline$=9$ & (19:2: & \multicolumn{4}{|c|}{ Sermant Turninor } \\
\hline 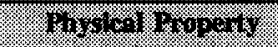 & (3) & 4 & (3) & 6) & 8 \\
\hline Density $(\mathrm{g} / \mathrm{mL})$ & Sludge & $1.42^{1}$ & $1.24^{1}$ & $1.24^{1}$ & $1.24^{1}$ \\
\hline & Centrifuged supernatant & 1.13 & 1.12 & 1.13 & 1.12 \\
\hline & Centrifuged solids & 1.52 & 1.33 & 1.31 & 1.30 \\
\hline Vol\% settled solids & & 100 & 86.5 & 82.2 & 87.5 \\
\hline $\mathrm{Wt} \%$ undissolved solids & & 39.7 & 21.9 & 23.6 & 23.2 \\
\hline Wt\% solids & & 43.3 & 28.0 & 29.2 & 28.7 \\
\hline Vol\% centrifuged solid & & 74.1 & 57.1 & 63.9 & 64.0 \\
\hline $\mathrm{Wt} \%$ centrifuged solids & & 79.4 & 61.2 & 67.3 & 67.4 \\
\hline
\end{tabular}

Note:

${ }^{1}$ PNNL 325 Laboratory results

Table B2-5. Tank 241-T-104 Analytical Results: Density (Physical Properties). (2 sheets)

\begin{tabular}{|c|c|c|c|}
\hline 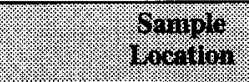 & $\begin{array}{l}\text { Somple: } \\
\text { Sortinu }\end{array}$ & & Ressin \\
\hline Sollos & (1: & ( & glone \\
\hline 45: 1 & WHOLE & 1.74 & \\
\hline \multirow[t]{2}{*}{ 45: 2} & WHOLE & 1.01 & \\
\hline & WHOLE & 1.42 & \\
\hline $45: 3$ & WHOLE & 1 & \\
\hline \multirow[t]{2}{*}{$45: 4$} & WHOLE & 1.2 & \\
\hline & WHOLE & 1.24 & \\
\hline $45: 5$ & WHOLE & 0.086 & \\
\hline \multirow[t]{2}{*}{ 45: 6} & WHOLE & 0.94 & \\
\hline & WHOLE & 1.24 & \\
\hline $45: 7$ & WHOLE & 1.04 & \\
\hline
\end{tabular}


Table B2-5. Tank 241-T-104 Analytical Results: Density (Physical Properties). (2 sheets)

\begin{tabular}{|c|c|c|}
\hline $\begin{array}{l}\text { Sample } \\
\text { Loeation }\end{array}$ & $\begin{array}{l}\text { Sample } \\
\text { Tortion }\end{array}$ & (1:0) Resuli \\
\hline \multirow[t]{2}{*}{$45: 8$} & WHOLE & 0.99 \\
\hline & WHOLE & 1.24 \\
\hline $45: 9$ & WHOLE & 1.15 \\
\hline $46: 2$ & WHOLE & 1.13 \\
\hline $46: 3$ & WHOLE & 1 \\
\hline 46: 4 & WHOLE & 0.99 \\
\hline $46: 5$ & WHOLE & 0.99 \\
\hline $46: 6$ & WHOLE & 1.19 \\
\hline 46: 7 & WHOLE & 1 \\
\hline $46: 8$ & WHOLE & 1.07 \\
\hline $46: 9$ & WHOLE & 1.03 \\
\hline (1.4. Iiquils. & V: & ghail \\
\hline $45: 6$ & WHOLE & 0.81 \\
\hline $45: 7$ & WHOLE & 1.16 \\
\hline $46: 3$ & WHOLE & 0.69 \\
\hline $46: 6$ & WHOLE & 0.75 \\
\hline $46: 7$ & WHOLE & 1.3 \\
\hline $46: 8$ & WHOLE & 0.9 \\
\hline
\end{tabular}


HNF-SD-WM-ER-372 Rev. 1

Table B2-6. Tank 241-T-104 Particle Size Data. ${ }^{1}$

\begin{tabular}{|c|c|c|c|c|}
\hline (4) & 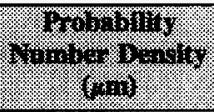 & 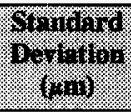 & 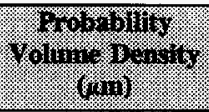 & 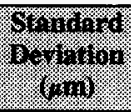 \\
\hline $45: 1$ & 1.04 & 0.78 & 9.08 & 11.1 \\
\hline $45: 2$ & 1.08 & 0.82 & 37.9 & 41.4 \\
\hline $45: 3$ & 1.25 & 1.40 & 46.8 & 32.8 \\
\hline $45: 4$ & 1.13 & 0.97 & 31.0 & 28.0 \\
\hline $45: 5$ & $\begin{array}{c}1.03 \\
1.05^{2}\end{array}$ & $\begin{array}{l}1.00 \\
1.06^{2}\end{array}$ & $\begin{array}{c}30.8 \\
33.8^{2}\end{array}$ & $\begin{array}{c}20.6 \\
19.9^{2}\end{array}$ \\
\hline $45: 6$ & 1.15 & 1.02 & 27.9 & 29.1 \\
\hline $45: 7$ & 1.01 & 0.81 & 34.4 & 36.7 \\
\hline $45: 8$ & 1.04 & 0.73 & 6.12 & $\begin{array}{c}61.05 \\
5.39\end{array}$ \\
\hline $45: 9$ & 1.06 & 1.06 & 27.4 & 22.7 \\
\hline $46: 2$ & 1.04 & 0.85 & 50.9 & 39.5 \\
\hline $46: 3$ & 1.07 & 0.86 & 12.8 & 18.7 \\
\hline $46: 4$ & 1.01 & 0.81 & 23.4 & 30.7 \\
\hline $46: 5$ & 0.99 & 0.78 & 49.0 & 51.3 \\
\hline $46: 6$ & 1.13 & 0.91 & 20.2 & 22.0 \\
\hline $46: 7$ & 0.95 & 0.68 & 6.81 & 7.97 \\
\hline $46: 8$ & 0.81 & 0.38 & 5.14 & 4.73 \\
\hline $46: 9$ & 1.05 & 0.81 & 16.1 & 19.8 \\
\hline
\end{tabular}

Notes:

'Pool (1994)

${ }^{2}$ Duplicate sample of Core 45 , Segment 5

Table B2-7. Shear Strength Results.

\begin{tabular}{|c|c|}
\hline Wysing & (1. \\
\hline 2 & 18,800 \\
\hline 4 & 3,500 \\
\hline 6 & $<500$ \\
\hline 8 & 13,800 \\
\hline
\end{tabular}


Table B2-8. Tank 241-T-104 Analytical Results: Aluminum (ICP).

\begin{tabular}{|c|c|c|c|c|c|}
\hline 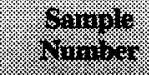 & 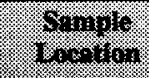 & Mring & $18+11$ & $(8,13+10 \cdot 10$ & M1 \\
\hline \multicolumn{2}{|c|}{ 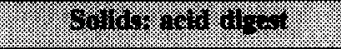 } & & 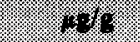 & $1 \%$ & $4 \%$ \\
\hline $147^{1}$ & \multirow[t]{2}{*}{ 46: 2} & WHOLE & 25,200 & 23,900 & $24,550^{\mathrm{QC}: 4,8}$ \\
\hline $146^{1}$ & & WHOLE & 23,900 & 24,100 & $24,000^{\mathrm{QC}: 4,8}$ \\
\hline 175 & \multirow{2}{*}{$\begin{array}{l}\text { Core } 45 \\
\text { Composite }\end{array}$} & WHOLE & 17,400 & 16,000 & $16,700^{\mathrm{QC}: 8}$ \\
\hline 176 & & WHOLE & 18,300 & 18,000 & $18,150^{\mathrm{QC}: 4,8}$ \\
\hline 179 & \multirow{2}{*}{$\begin{array}{l}\text { Core } 46 \\
\text { Composite }\end{array}$} & WHOLE & 15,500 & 14,800 & 15,150 \\
\hline 180 & & WHOLE & 15,000 & 14,900 & 14,950 \\
\hline \multicolumn{2}{|c|}{ 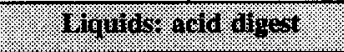 } & & \% & 6911 & 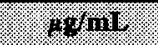 \\
\hline 204 & $\begin{array}{l}\text { Core } 46 \\
\text { Composite }\end{array}$ & $\mathrm{DL}$ & 3,160 & -- & $3,160^{Q C: 8,13}$ \\
\hline \multicolumn{2}{|c|}{ 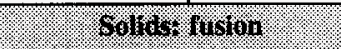 } & & $\% \% 8$ & 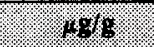 & 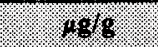 \\
\hline 175 & \multirow{2}{*}{$\begin{array}{l}\text { Core } 45 \\
\text { Composite }\end{array}$} & WHOLE & 17,800 & 18,000 & 17,900 \\
\hline 176 & & WHOLE & 17,300 & 17,000 & 17,150 \\
\hline 179 & \multirow{2}{*}{$\begin{array}{l}\text { Core } 46 \\
\text { Composite }\end{array}$} & WHOLE & 13,900 & 13,700 & $13,800^{\mathrm{QC}: 4,10}$ \\
\hline 180 & & $\overline{\text { WHOLE }}$ & 14,100 & 13,300 & $13,700^{Q C: 4,10}$ \\
\hline \multicolumn{2}{|c|}{ 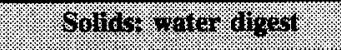 } & & 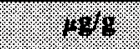 & 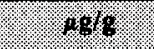 & 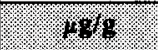 \\
\hline 175 & \multirow{2}{*}{$\begin{array}{l}\text { Core } 45 \\
\text { Composite }\end{array}$} & WHOLE & 122 & 127 & $124.5^{\mathrm{QC}: 7}$ \\
\hline 176 & & WHOLE & 153 & 179 & $166^{\mathrm{QC}: 7}$ \\
\hline 179 & \multirow{2}{*}{$\begin{array}{l}\text { Core } 46 \\
\text { Composite }\end{array}$} & WHOLE & 164 & 162 & $163^{\mathrm{QC} 5}$ \\
\hline 180 & & WHOLE & 181 & 176 & $178.5^{\mathrm{QC}: 5}$ \\
\hline
\end{tabular}

Notes:

DL $=$ Drainable liquid

'Homogenization test sample 
Table B2-9. Tank 241-T-104 Analytical Results: Antimony (ICP).

\begin{tabular}{|c|c|c|c|c|c|}
\hline $\begin{array}{l}\text { Sample: } \\
\text { Number. }\end{array}$ & $\begin{array}{l}\text { Sample } \\
\text { Lacationa }\end{array}$ & $\begin{array}{l}\text { Sample } \\
\text { Portion. }\end{array}$ & Resinit & Dipllcate & Mean \\
\hline \multicolumn{2}{|c|}{ Sollids a did digest } & & 1986 & .1849 & 1909 \\
\hline $147^{1}$ & \multirow[t]{2}{*}{$46: 2$} & WHOLE & $<34.7$ & $<35.2$ & $<34.95^{0 \mathrm{CO}: 4,7,8}$ \\
\hline $146^{1}$ & & WHOLE & $<35$ & $<35.3$ & $<35.15^{\mathrm{QC}: 4.7,8}$ \\
\hline 175 & \multirow{2}{*}{\begin{tabular}{|l|} 
Core 45 \\
Composite
\end{tabular}} & WHOLE & $<33.7$ & $<34.2$ & $<33.95^{\mathrm{QC}: 4,7}$ \\
\hline 176 & & WHOLE & $<48.8$ & $<51.7$ & $<50.25^{0 C \cdot 7,8}$ \\
\hline 179 & \multirow{2}{*}{$\begin{array}{l}\text { Core } 46 \\
\text { Composite }\end{array}$} & WHOLE & $<35.5$ & $<35.2$ & $<35.35^{\text {QC4,7,8 }}$ \\
\hline 180 & & WHOLE & $<35.2$ & $<35$ & $<35.1^{\mathrm{QC}: 4,7,8}$ \\
\hline \multicolumn{2}{|c|}{ Uiquids acid digest } & & yefint: & rginil. & Mg/mi \\
\hline 204 & $\begin{array}{l}\text { Core } 46 \\
\text { Composite }\end{array}$ & $\mathrm{DL}$ & $<3.56$ & --- & $<3.56^{\mathrm{OC}: 4.7}$ \\
\hline \multicolumn{2}{|c|}{ Solldst fusion } & & 1986 & 1898 & 1989 \\
\hline 175 & \multirow{2}{*}{$\begin{array}{l}\text { Core } 45 \\
\text { Composite }\end{array}$} & WHOLE & $<176$ & $<176$ & $<176^{\mathrm{QC}: 7}$ \\
\hline 176 & & WHOLE & $<177$ & $<177$ & $<177^{\mathrm{QC}: 7}$ \\
\hline 179 & \multirow{2}{*}{\begin{tabular}{|l} 
Core 46 \\
Composite
\end{tabular}} & WHOLE & $<75.7$ & $<75.8$ & $<75.75^{\mathrm{QC}: 4,7}$ \\
\hline 180 & & WHOLE & $<75.4$ & $<75.1$ & $<75.25^{\mathrm{QC:4.7}}$ \\
\hline \multicolumn{2}{|c|}{ Solids, water digest } & & $\mu 9 / 8$ & 1498 & $14 \mathrm{~g} / \mathrm{g}$ \\
\hline 175 & \multirow{2}{*}{\begin{tabular}{|l} 
Core 45 \\
Composite
\end{tabular}} & WHOLE & $<36.1$ & $<36.1$ & $<36.1^{00: 7}$ \\
\hline 176 & & WHOLE & $<36.2$ & $<36.3$ & $<36.25^{\mathrm{QC}: 7}$ \\
\hline 179 & \multirow{2}{*}{$\begin{array}{l}\text { Core } 46 \\
\text { Composite }\end{array}$} & WHOLE & $<36.2$ & $<36.2$ & $<36.2^{\mathrm{QC}: 4,7}$ \\
\hline 180 & & WHOLE & $<35.6$ & $<35.9$ & $<35.75^{\mathrm{QC}: 4.7}$ \\
\hline
\end{tabular}

Note:

Homogenization test sample 
Table B2-10. Tank 241-T-104 Analytical Results: Arsenic (ICP).

\begin{tabular}{|c|c|c|c|c|c|}
\hline \% & 策, & 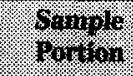 & Picsili & 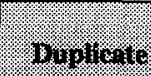 & 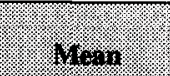 \\
\hline \multicolumn{2}{|c|}{ 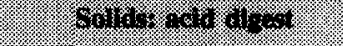 } & & $8 \%$ & 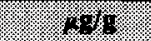 & 1610 \\
\hline $147^{1}$ & \multirow[t]{2}{*}{ 46: 2} & WHOLE & 3.56 & 6.52 & $5.04^{\mathrm{QC}: 7,9}$ \\
\hline $146^{1}$ & & WHOLE & 4.19 & $<3.07$ & $<3.63^{\mathrm{QC}: 7,9}$ \\
\hline 175 & \multirow{2}{*}{$\begin{array}{l}\text { Core } 45 \\
\text { Composite }\end{array}$} & WHOLE & 3.53 & $<2.98$ & $<3.255^{\text {QC:7,9 }}$ \\
\hline 176 & & WHOLE & $<4.25$ & $<4.5$ & $<4.375^{\mathrm{QC:} 7}$ \\
\hline 179 & \multirow{2}{*}{$\begin{array}{l}\text { Core } 46 \\
\text { Composite }\end{array}$} & WHOLE & $<3.09$ & 3.95 & $<3.52^{\mathrm{QC}: 7,9}$ \\
\hline 180 & & WHOLE & 3.34 & $<3.05$ & $<3.195^{\mathrm{QC}: 7,9}$ \\
\hline \multicolumn{2}{|c|}{ 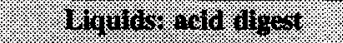 } & & H, 113 & $106 / 111 \%$ & 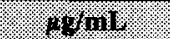 \\
\hline 204 & $\begin{array}{l}\text { Core } 46 \\
\text { Composite }\end{array}$ & $\mathrm{DL}$ & 0.615 & -- & $0.615^{\mathrm{QC}: 7}$ \\
\hline \multicolumn{2}{|c|}{ 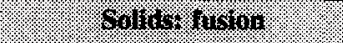 } & & 1818 & 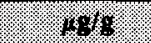 & $10 \%$ \\
\hline 175 & \multirow{2}{*}{$\begin{array}{l}\text { Core } 45 \\
\text { Composite }\end{array}$} & WHOLE & $<15.3$ & $<15.3$ & $<15.3^{\mathrm{QC}: 7}$ \\
\hline 176 & & WHOLE & $<15.4$ & $<15.4$ & $<15.4^{\mathrm{QC:7}}$ \\
\hline 179 & \multirow{2}{*}{$\begin{array}{l}\text { Core } 46 \\
\text { Composite }\end{array}$} & WHOLE & $<19.4$ & $<19.5$ & $<19.45^{\mathrm{QC}: 7}$ \\
\hline 180 & & WHOLE & $<19.3$ & $<19.3$ & $<19.3^{\mathrm{QC}: 7}$ \\
\hline \multicolumn{2}{|c|}{ 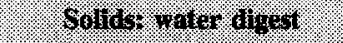 } & & 1496 & $49 / 8$ & 1048 \\
\hline $\begin{array}{l}61.05 \\
175\end{array}$ & \multirow[t]{2}{*}{$\begin{array}{l}\text { Core } 45 \\
\text { Composite }\end{array}$} & WHOLE & $<3.15$ & $<3.15$ & $<3.15^{\mathrm{QC}: 7}$ \\
\hline 176 & & WHOLE & $<3.15$ & $<3.16$ & $<3.155^{\mathrm{QC}: 7}$ \\
\hline 179 & \multirow{2}{*}{$\begin{array}{l}\text { Core } 46 \\
\text { Composite }\end{array}$} & WHOLE & 3.77 & $<3.16$ & $<3.465^{\mathrm{OC}: 7}$ \\
\hline 180 & & WHOLE & $<3.1$ & $<3.12$ & $<3.11^{\mathrm{QC:}: 7}$ \\
\hline
\end{tabular}

Note:

${ }^{1}$ Homogenization test sample 
Table B2-11. Tank 241-T-104 Analytical Results: Barium (ICP).

\begin{tabular}{|c|c|c|c|c|c|}
\hline Yamplo & Womplo & Garioule & 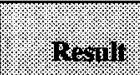 & 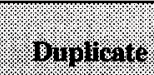 & $114=a n$ \\
\hline \multicolumn{2}{|c|}{ 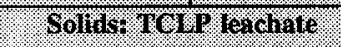 } & & $4111 \%$ & 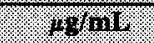 & \% \\
\hline 199 & \multirow{2}{*}{$\begin{array}{l}\text { Core } 45 \\
\text { Composite }\end{array}$} & WHOLE & 8.07 & --- & 8.07 \\
\hline 196 & & WHOLE & $<0.02$ & $<0.02$ & $<0.02$ \\
\hline \multicolumn{2}{|c|}{ 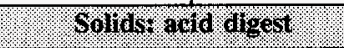 } & & $149 \mathrm{~g}$ & $1.10 \mathrm{~g}$ & 1698 \\
\hline $147^{1}$ & \multirow[t]{2}{*}{$46: 2$} & WHOLE & 9.91 & 9.89 & $9.9^{\mathrm{QC}: 7}$ \\
\hline $146^{1}$ & & WHOLE & 9.3 & 9.69 & $9.495^{\mathrm{QC}: 7}$ \\
\hline 175 & \multirow{2}{*}{$\begin{array}{l}\text { Core } 45 \\
\text { Composite }\end{array}$} & WHOLE & 7.29 & 6.63 & $6.96^{\mathrm{QC}: 7}$ \\
\hline 176 & & WHOLE & 8.03 & 7.64 & $7.835^{\mathrm{QC}-7}$ \\
\hline 179 & \multirow{2}{*}{$\begin{array}{l}\text { Core } 46 \\
\text { Composite }\end{array}$} & WHOLE & 7.62 & 7.41 & $7.515^{\mathrm{QC:7}}$ \\
\hline 180 & & WHOLE & 8.17 & 8.36 & $8.265^{\mathrm{QC:7}}$ \\
\hline \multicolumn{2}{|c|}{ Wiajust add digest } & & $4 \%$ grul & 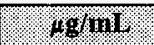 & (1) \\
\hline 204 & $\begin{array}{l}\text { Core } 46 \\
\text { Composite }\end{array}$ & DL & 2.08 & -- & $2.08^{\mathrm{QC}^{2} 7}$ \\
\hline \multicolumn{2}{|c|}{ Solius. fusion } & & 49 & 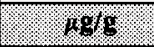 & 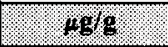 \\
\hline 175 & \multirow{2}{*}{$\begin{array}{l}\text { Core } 45 \\
\text { Composite }\end{array}$} & WHOLE & 9 & 7.98 & $8.49^{\mathrm{QC}: 7}$ \\
\hline 176 & & WHOLE & 9.79 & 8.28 & $9.035^{\mathrm{QC:7}}$ \\
\hline 179 & \multirow{2}{*}{\begin{tabular}{|l|} 
Core 46 \\
Composite
\end{tabular}} & WHOLE & 8.19 & 8.61 & $8.4^{\mathrm{QCi}}$ \\
\hline 180 & & WHOLE & 8.15 & 8.61 & $8.38^{Q C 7}$ \\
\hline \multicolumn{2}{|c|}{ Sollds? yater digest } & & 49 & 198 & \%o: \\
\hline 175 & \multirow{2}{*}{$\begin{array}{l}\text { Core } 45 \\
\text { Composite }\end{array}$} & WHOLE & $<0.304$ & 0.322 & $<0.313^{\mathrm{QC}: 7}$ \\
\hline 176 & & WHOLE & 0.325 & $<0.306$ & $<0.3155^{\mathrm{OC} 7}$ \\
\hline 179 & \multirow{2}{*}{$\begin{array}{l}\text { Core } 46 \\
\text { Composite }\end{array}$} & WHOLE & $<0.305$ & $<0.305$ & $<0.305^{Q C 7}$ \\
\hline 180 & & WHOLE & 0.306 & $<0.302$ & $<0.304^{\mathrm{QC}: 7.9}$ \\
\hline
\end{tabular}

Note:

${ }^{1}$ Homogenization test sample 
Table B2-12. Tank 241-T-104 Analytical Results: Beryllium (ICP).

\begin{tabular}{|c|c|c|c|c|c|}
\hline $\begin{array}{l}\text { Sample } \\
\text { Number. }\end{array}$ & $\begin{array}{l}\text { Sample: } \\
\text { Eucation }\end{array}$ & $\begin{array}{l}\text { Sample } \\
\text { Portion }\end{array}$ & resill & Muplicale. & Mean \\
\hline \multicolumn{3}{|c|}{ Solids: actid digest } & 1896 & $.148 \mathrm{~s}$ & .496 \\
\hline $147^{1}$ & \multirow[t]{2}{*}{$46: 2$} & WHOLE & $<0.293$ & $<0.297$ & $<0.295^{\mathrm{QC}: 7}$ \\
\hline $146^{1}$ & & WHOLE & $<0.295$ & $<0.297$ & $<0.296^{\mathrm{QC}: 7}$ \\
\hline 175 & \multirow{2}{*}{\begin{tabular}{|l|} 
Core 45 \\
Composite
\end{tabular}} & WHOLE & $<0.284$ & $<0.288$ & $<0.286^{\mathrm{QC}: 7}$ \\
\hline 176 & & WHOLE & $<0.411$ & $<0.435$ & $<0.423^{\mathrm{QC}: 7}$ \\
\hline 179 & \multirow{2}{*}{\begin{tabular}{|l|} 
Core 46 \\
Composite
\end{tabular}} & WHOLE & $<0.299$ & $<0.296$ & $<0.2975^{\mathrm{QC}: 7}$ \\
\hline 180 & & WHOLE & $<0.296$ & $<0.295$ & $<0.2955$ \\
\hline \multicolumn{2}{|c|}{ Iiquilds: acid digest } & & $.9 . \mathrm{ml}$ & $4 \mathrm{~g} / \mathrm{ml}$ & $48 / \mathrm{mL}$ \\
\hline 204 & \begin{tabular}{|l|} 
Core 46 \\
Composite
\end{tabular} & $\mathrm{DL}$ & 0.03 & --- & 0.03 \\
\hline \multicolumn{3}{|c|}{ Soluds frusion } & 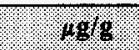 & 1.818 & 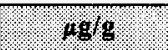 \\
\hline 175 & \multirow{2}{*}{$\begin{array}{l}\text { Core } 45 \\
\text { Composite }\end{array}$} & WHOLE & $<1.48$ & $<1.48$ & $<1.48^{\mathrm{QC}: 7}$ \\
\hline 176 & & WHOLE & $<1.49$ & $<1.49$ & $<1.49^{\mathrm{QC7}}$ \\
\hline 179 & \multirow{2}{*}{\begin{tabular}{|l|} 
Core 46 \\
Composite
\end{tabular}} & WHOLE & $<1.49$ & $<1.5$ & $<1.495$ \\
\hline 180 & & WHOLE & $<1.49$ & $<1.48$ & $<1.485$ \\
\hline \multicolumn{2}{|c|}{ Sollds; water digest } & & $49 / 9$ & $4 \mathrm{~g} / \mathrm{g}$ & $199 / 8$ \\
\hline 175 & \multirow{2}{*}{$\begin{array}{l}\text { Core } 45 \\
\text { Composite }\end{array}$} & WHOLE & $<0.304$ & $<0.304$ & $<0.304^{\mathrm{QC}: ?}$ \\
\hline 176 & & WHOLE & $<0.305$ & $<0.306$ & $<0.3055^{0 \mathrm{cc}}$ \\
\hline 179 & \multirow{2}{*}{$\begin{array}{l}\text { Core } 46 \\
\text { Composite }\end{array}$} & WHOLE & $<0.305$ & $<0.305$ & $<0.305^{\mathrm{QC}: 7}$ \\
\hline 180 & & WHOLE & $<0.3$ & $<0.302$ & $<0.301^{\mathrm{QC}: 7}$ \\
\hline
\end{tabular}

Note:

${ }^{1}$ Homogenization test sample 
HNF-SD-WM-ER-372 Rev. 1

Table B2-13. Tank 241-T-104 Analytical Results: Bismuth (ICP).

\begin{tabular}{|c|c|c|c|c|c|}
\hline (4) & 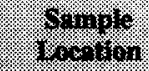 & 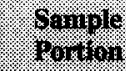 & (1) & (3) & 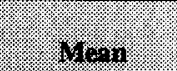 \\
\hline \multicolumn{2}{|c|}{ 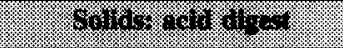 } & & 8,4 & $4=4$ & $4 \%$ \\
\hline $147^{1}$ & \multirow[t]{2}{*}{$46: 2$} & WHOLE & 25,600 & 24,700 & $25,150^{\mathrm{QC}: 4,7,8,9}$ \\
\hline $146^{1}$ & & WHOLE & 24,200 & 23,600 & $23,900^{\mathrm{QC}: 4,7,8}$ \\
\hline 175 & \multirow{2}{*}{$\begin{array}{l}\text { Core } 45 \\
\text { Composite }\end{array}$} & WHOLE & 20,000 & 18,000 & $19,000^{\mathrm{QC:}: 4}$ \\
\hline 176 & & WHOLE & 19,800 & 19,100 & $19,450^{\mathrm{QC}: 4}$ \\
\hline 179 & \multirow{2}{*}{$\begin{array}{l}\text { Core } 46 \\
\text { Composite }\end{array}$} & WHOLE & 18,500 & 17,700 & $18,100^{\mathrm{QC}: 4,7}$ \\
\hline 180 & & WHOLE & 18,700 & 19,200 & $18,950^{Q C: 4,7}$ \\
\hline \multicolumn{2}{|c|}{ 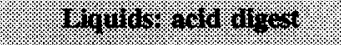 } & & Hornt & 101101 & 64 in \\
\hline 204 & $\begin{array}{l}\text { Core } 46 \\
\text { Composite }\end{array}$ & DL & 485 & --- & $485^{\mathrm{QC} 4,7}$ \\
\hline \multicolumn{2}{|c|}{ 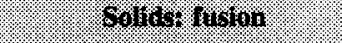 } & & 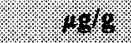 & $x_{3} x_{5}$ & $\%$ \\
\hline 175 & \multirow{2}{*}{$\begin{array}{l}\text { Core } 45 \\
\text { Composite }\end{array}$} & WHOLE & 18,300 & 19,100 & $18,700^{\mathrm{QC}: 4}$ \\
\hline 176 & & WHOLE & 17,700 & 18,700 & $18,200^{\mathrm{QC}: 4}$ \\
\hline 179 & \multirow{2}{*}{$\begin{array}{l}\text { Core } 46 \\
\text { Composite }\end{array}$} & WHOLE & 16,700 & 15,700 & $16,200^{\mathrm{QC}: 4,7}$ \\
\hline 180 & & WHOLE & 16,300 & 16,300 & $16,300^{0 \mathrm{ec} 4,7}$ \\
\hline \multicolumn{2}{|c|}{ 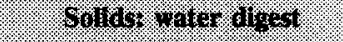 } & & $180 \%$ & $4 \%$ & 1849 \\
\hline 175 & \multirow{2}{*}{$\begin{array}{l}\text { Core } 45 \\
\text { Composite }\end{array}$} & WHOLE & 118 & 139 & $128.5^{\mathrm{QC} 4}$ \\
\hline 176 & & WHOLE & 175 & 213 & $194^{\mathrm{QC}: 4}$ \\
\hline 179 & \multirow{2}{*}{$\begin{array}{l}\text { Core } 46 \\
\text { Composite }\end{array}$} & WHOLE & 176 & 170 & $173^{Q C: 4,7,10}$ \\
\hline 180 & & WHOLE & 198 & 156 & $177^{\mathrm{QC}: 4,7,9,10}$ \\
\hline
\end{tabular}

Note:

${ }^{1}$ Homogenization test sample 
Table B2-14. Tank 241-T-104 Analytical Results: Boron (ICP),

\begin{tabular}{|c|c|c|c|c|c|}
\hline \%quph & (Wine & 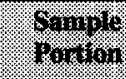 & \% & (2) & (16+13 \\
\hline \multicolumn{2}{|c|}{ 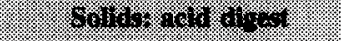 } & & $1 \%$ & $4 \%$ & $1 \%$ \\
\hline $147^{1}$ & \multirow[t]{2}{*}{$46: 2$} & WHOLE & 5.24 & 3.75 & $4.495^{\mathrm{QC}: 5,7,8,9}$ \\
\hline $146^{1}$ & & WHOLE & 9.99 & 3.99 & $6.99^{Q C \cdot 5,7,8,9}$ \\
\hline 175 & \multirow{2}{*}{$\begin{array}{l}\text { Core } 45 \\
\text { Composite }\end{array}$} & WHOLE & 17.2 & 11.9 & $14.55^{\mathrm{QC}: 7,8,9}$ \\
\hline 176 & & WHOLE & 14.6 & 23.6 & $19.1^{\mathrm{QC}: 7,8,9}$ \\
\hline 179 & \multirow{2}{*}{$\begin{array}{l}\text { Core } 46 \\
\text { Composite }\end{array}$} & WHOLE & 10.5 & 19.6 & $15.05^{\mathrm{QC}: 5,7,8,9}$ \\
\hline 180 & & WHOLE & 13.5 & 14.1 & $13.8^{Q C: 5,7,8}$ \\
\hline \multicolumn{2}{|c|}{ 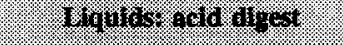 } & & 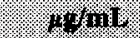 & $1.6,1111$ & $15 \% 11$ \\
\hline 204 & $\begin{array}{l}\text { Core } 46 \\
\text { Composite }\end{array}$ & $\mathrm{DL}$ & 7.64 & -- & $7.64^{\mathrm{QC}: 7,8,13}$ \\
\hline \multicolumn{2}{|c|}{ 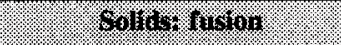 } & & 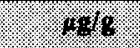 & 196 & 40 \\
\hline 175 & \multirow{2}{*}{$\begin{array}{l}\text { Core } 45 \\
\text { Composite }\end{array}$} & WHOLE & $<9.37$ & $<9.39$ & $<9.38^{\mathrm{QC}: 7}$ \\
\hline 176 & & WHOLE & $<9.44$ & $<9.44$ & $<9.44^{\mathrm{QC}: 7}$ \\
\hline 179 & \multirow{2}{*}{$\begin{array}{l}\text { Core } 46 \\
\text { Composite }\end{array}$} & WHOLE & $<4.98$ & $<4.99$ & $<4.985^{\mathrm{QC}: 7}$ \\
\hline 180 & & WHOLE & $<4.96$ & $<4.94$ & $<4.95^{\mathrm{QC}: 7}$ \\
\hline \multicolumn{2}{|c|}{ 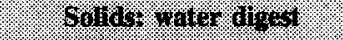 } & & 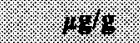 & $10 \%$ & +4 \\
\hline 175 & \multirow{2}{*}{$\begin{array}{l}\text { Core } 45 \\
\text { Composite }\end{array}$} & WHOLE & 10.5 & 10.8 & $10.65^{\mathrm{QC}: 7}$ \\
\hline 176 & & WHOLE & 11.8 & 10.3 & $11.05^{\mathrm{QC}: 7}$ \\
\hline 179 & \multirow{2}{*}{$\begin{array}{l}\text { Core } 46 \\
\text { Composite }\end{array}$} & WHOLE & 12.3 & 12.7 & $12.5^{\mathrm{QC}: 7}$ \\
\hline 180 & & WHOLE & 11.8 & 11.6 & $11.7^{\mathrm{QC}: 7}$ \\
\hline
\end{tabular}

Note:

${ }^{1}$ Homogenization test sample 
Table B2-15. Tank 241-T-104 Analytical Results: Cadmium (ICP).

\begin{tabular}{|c|c|c|c|c|c|}
\hline 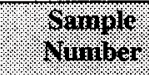 & 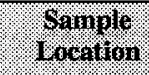 & Syovolo & resill & Guplosite & 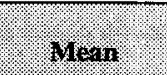 \\
\hline \multicolumn{2}{|c|}{ 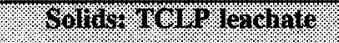 } & & \% 1111 & 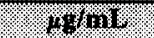 & $4 / 111$ \\
\hline 199 & \multirow{2}{*}{$\begin{array}{l}\text { Core } 45 \\
\text { Composite }\end{array}$} & WHOLE & 0.815 & -- & 0.815 \\
\hline 196 & & WHOLE & $<0.035$ & $<0.035$ & $<0.035$ \\
\hline \multicolumn{2}{|c|}{ Solldst acid ongest } & & $16 \mathrm{~g} / \mathrm{g}$ & $68 / 5$ & 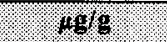 \\
\hline $147^{1}$ & \multirow[t]{2}{*}{$46: 2$} & WHOLE & 3.08 & 4.01 & $3.545^{0 \times 7,9}$ \\
\hline $146^{1}$ & & WHOLE & 2.63 & 2.84 & $2.735^{\mathrm{QC}: 7}$ \\
\hline 175 & \multirow{2}{*}{$\begin{array}{l}\text { Core } 45 \\
\text { Composite }\end{array}$} & WHOLE & 1.93 & 1.84 & $1.885^{\mathrm{QC}: 7}$ \\
\hline 176 & & WHOLE & 1.8 & 1.25 & $1.525^{\mathrm{QC:} 7}$ \\
\hline 179 & \multirow{2}{*}{$\begin{array}{l}\text { Core } 46 \\
\text { Composite }\end{array}$} & WHOLE & 1.47 & 1.84 & $1.655^{0 C 7,9}$ \\
\hline 180 & & WHOLE & 1.71 & 1.7 & $1.705^{\mathrm{QC}: 7}$ \\
\hline \multicolumn{2}{|c|}{ Youids acid olgest } & & $t+111$ & (wo & 481110 \\
\hline 204 & $\begin{array}{l}\text { Core } 46 \\
\text { Composite }\end{array}$ & DL & 0.278 & -- & $0.278^{\mathrm{QC}: 7}$ \\
\hline \multicolumn{2}{|c|}{ Solids frision } & & 496 & 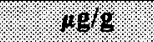 & 16/g \\
\hline 175 & \multirow{2}{*}{$\begin{array}{l}\text { Core } 45 \\
\text { Composite }\end{array}$} & WHOLE & 3.88 & $<3.46$ & $<3.67^{\mathrm{QC} \cdot 7}$ \\
\hline 176 & & WHOLE & 4.57 & $<3.48$ & $<4.025^{\mathrm{QC} 7}$ \\
\hline 179 & \multirow{2}{*}{$\begin{array}{l}\text { Core } 46 \\
\text { Composite }\end{array}$} & WHOLE & 4.95 & 8.2 & $6.575^{0 \mathrm{QC} 6.7,9}$ \\
\hline 180 & & WHOLE & 8.7 & 6.25 & $7.475^{\mathrm{QC}: 6.7,9}$ \\
\hline \multicolumn{2}{|c|}{ Solids, water digest } & & $108 / 8$ & 1968 & 40 \\
\hline 175 & \multirow{2}{*}{$\begin{array}{l}\text { Core } 45 \\
\text { Composite }\end{array}$} & WHOLE & $<0.71$ & $<0.71$ & $<0.71^{\mathrm{QC}: 7}$ \\
\hline 176 & & WHOLE & $<0.711$ & $<0.714$ & $<0.7125^{Q C .7}$ \\
\hline 179 & \multirow{2}{*}{$\begin{array}{l}\text { Core } 46 \\
\text { Composite }\end{array}$} & WHOLE & $<0.711$ & $<0.713$ & $<0.712^{\mathrm{QC}: 7}$ \\
\hline 180 & & WHOLE & $<0.701$ & $<0.706$ & $<0.7035^{007}$ \\
\hline
\end{tabular}

Note:

'Homogenization test sample 
HNF-SD-WM-ER-372 Rev. 1

Table B2-16. Tank 241-T-104 Analytical Results: Calcium (ICP).

\begin{tabular}{|c|c|c|c|c|c|}
\hline Sample & 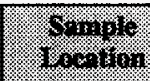 & 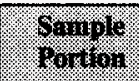 & 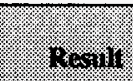 & Hoblome & 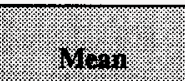 \\
\hline \multicolumn{2}{|c|}{ 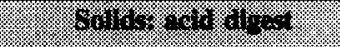 } & ? & 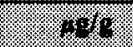 & $4.8 \%$ & 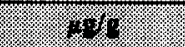 \\
\hline $147^{1}$ & \multirow[t]{2}{*}{$46: 2$} & WHOLE & 395 & 400 & $397.5^{\mathrm{CC}: 4,8,13}$ \\
\hline $146^{1}$ & & WHOLE & 358 & 350 & $354^{\mathrm{QC}: 4,8,13}$ \\
\hline 175 & \multirow{2}{*}{\begin{tabular}{|l} 
Core 45 \\
Composite
\end{tabular}} & WHOLE & 215 & 192 & $203.5^{\text {QC: } 7,10,13}$ \\
\hline 176 & & WHOLE & 247 & 247 & $247^{\mathrm{QC}: 8,10,13}$ \\
\hline 179 & \multirow{2}{*}{\begin{tabular}{|l} 
Core 46 \\
Composite
\end{tabular}} & WHOLE & 296 & 221 & $258.5^{\mathrm{QC}: 5,7,8,9,10}$ \\
\hline 180 & & WHOLE & 369 & 312 & $340.5^{\mathrm{QC}: 5,7,8,10}$ \\
\hline \multicolumn{2}{|c|}{ 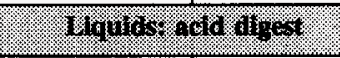 } & & Hom & $4 \%$ in & ingin: \\
\hline 204 & $\begin{array}{l}\text { Core } 46 \\
\text { Composite }\end{array}$ & DL & 23.3 & -- & $23.3^{\mathrm{ec}: 7,8}$ \\
\hline \multicolumn{2}{|c|}{ 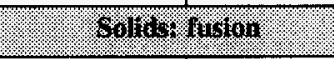 } & & 4.98 & 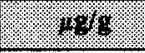 & 1488 \\
\hline 175 & \multirow{2}{*}{$\begin{array}{l}\text { Core } 45 \\
\text { Composite }\end{array}$} & WHOLE & 6,720 & 771 & $3,745.5^{\mathrm{OC}: 7,9}$ \\
\hline 176 & & WHOLE & 607 & 539 & $573^{\mathrm{QC}: 7}$ \\
\hline 179 & \multirow{2}{*}{\begin{tabular}{|l} 
Core 46 \\
Composite
\end{tabular}} & WHOLE & 575 & 997 & $786^{\mathrm{QC}: 6,7,9}$ \\
\hline 180 & & WHOLE & 801 & 577 & $689^{\mathrm{QC}: 6,7,9}$ \\
\hline \multicolumn{2}{|c|}{ Solidst yater gingest } & & 14818 & 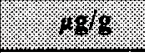 & 1896 \\
\hline 175 & \multirow{2}{*}{$\begin{array}{l}\text { Core } 45 \\
\text { Composite }\end{array}$} & WHOLE & 191 & 154 & $172.5^{\mathrm{QC}: 7,13}$ \\
\hline 176 & & WHOLE & 192 & 196 & $194^{\text {QC:7,13 }}$ \\
\hline 179 & \multirow{2}{*}{$\begin{array}{l}\text { Core } 46 \\
\text { Composite }\end{array}$} & WHOLE & 176 & 147 & $161.5^{\text {QC:5.7 }}$ \\
\hline 180 & & WHOLE & 175 & 140 & $157.5^{\mathrm{QC}: 5,7,9}$ \\
\hline
\end{tabular}

Note:

${ }^{1}$ Homogenization test sample 
Table B2-17. Tank 241-T-104 Analytical Results: Cerium (ICP).

\begin{tabular}{|c|c|c|c|c|c|}
\hline 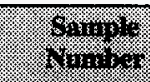 & Fingich & 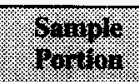 & 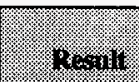 & $5401160 \%$ & 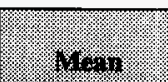 \\
\hline \multicolumn{2}{|c|}{ 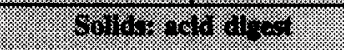 } & ? & 18 & 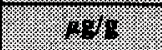 & $90 \%$ \\
\hline $147^{1}$ & \multirow[t]{2}{*}{$46: 2$} & WHOLE & 224 & 212 & $218^{Q C: 4,7,13}$ \\
\hline $146^{1}$ & & WHOLE & 212 & 209 & $210.5^{\mathrm{QC}: 4,7,13}$ \\
\hline 175 & \multirow{2}{*}{$\begin{array}{l}\text { Core } 45 \\
\text { Composite }\end{array}$} & WHOLE & 183 & 170 & $176.5^{\mathrm{QC}: 4}$ \\
\hline 176 & & WHOLE & 195 & 190 & $192.5^{\mathrm{QC}: 4}$ \\
\hline 179 & \multirow{2}{*}{$\begin{array}{l}\text { Core } 46 \\
\text { Composite }\end{array}$} & WHOLE & 197 & 192 & $194.5^{\mathrm{QC}: 4,7,13}$ \\
\hline 180 & & WHOLE & 209 & 217 & $213^{\mathrm{QC}: 4,7,13}$ \\
\hline \multicolumn{2}{|c|}{ 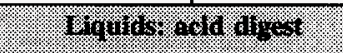 } & & 3. & $4.64 m 1$ & $96 / \mathrm{mil}:$ \\
\hline 204 & \begin{tabular}{|l} 
Core 46 \\
Composite
\end{tabular} & $\mathrm{DL}$ & 15.6 & -- & $15.6^{\mathrm{QC}: 4,7,13}$ \\
\hline \multicolumn{2}{|c|}{ ofolluk finson } & & 496 & $184 \%$ & .9818 \\
\hline 175 & \multirow{2}{*}{$\begin{array}{l}\text { Core } 45 \\
\text { Composite }\end{array}$} & WHOLE & 144 & 131 & $137.5^{\mathrm{QC}: 4}$ \\
\hline 176 & & WHOLE & 235 & 158 & $196.5^{\mathrm{QC}: 4}$ \\
\hline 179 & \multirow{2}{*}{$\begin{array}{l}\text { Core } 46 \\
\text { Composite }\end{array}$} & WHOLE & 156 & 177 & $166.5^{\mathrm{QC}: 4,7,13}$ \\
\hline 180 & & WHOLE & 124 & 153 & $138.5^{\mathrm{QC}: 4,7,9,13}$ \\
\hline \multicolumn{2}{|c|}{ Sollagt Yater digest } & & 1948 & $=19.98$ & 1989 \\
\hline 175 & \multirow{2}{*}{$\begin{array}{l}\text { Core } 45 \\
\text { Composite }\end{array}$} & WHOLE & $<8.73$ & $<8.73$ & $<8.73^{\mathrm{QC}: 4}$ \\
\hline 176 & & WHOLE & $<8.74$ & $<8.77$ & $<8.755^{\mathrm{QC:4}}$ \\
\hline 179 & \multirow{2}{*}{\begin{tabular}{|l|} 
Core 46 \\
Composite
\end{tabular}} & WHOLE & $<8.74$ & $<8.75$ & $<8.745^{\mathrm{eC}: 4,7}$ \\
\hline 180 & & WHOLE & $<8.61$ & $<8.67$ & $<8.64^{\mathrm{QC}: 4,7}$ \\
\hline
\end{tabular}

Note:

${ }^{1}$ Homogenization test sample 
HNF-SD-WM-ER-372 Rev. 1

Table B2-18. Tank 241-T-104 Analytical Results: Chromium (ICP).

\begin{tabular}{|c|c|c|c|c|c|}
\hline Wample & $\begin{array}{l}\text { Sample } \\
\text { I. }\end{array}$ & 89010 & Rosilit & Ouplisatic. & Stesin. \\
\hline \multicolumn{2}{|c|}{ 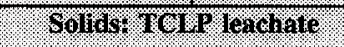 } & (1: & $491 \mathrm{mI}$ & $16 \% 11 \%$ & 165010 \\
\hline 199 & \multirow{2}{*}{$\begin{array}{l}\text { Core } 45 \\
\text { Composite }\end{array}$} & WHOLE & 8.52 & -- & 8.52 \\
\hline 196 & & WHOLE & 6.35 & 6.22 & $6.285^{\mathrm{QC:9}}$ \\
\hline \multicolumn{2}{|c|}{ Soldot ado ongest } & ?. & 1019 & $1 \% 9$ & $.10 \mathrm{~g}$ \\
\hline $147^{1}$ & \multirow[t]{2}{*}{$46: 2$} & WHOLE & 1,120 & 1,040 & 1,080 \\
\hline $146^{1}$ & & WHOLE & 1,030 & 1,030 & 1,030 \\
\hline 175 & \multirow{2}{*}{$\begin{array}{l}\text { Core } 45 \\
\text { Composite }\end{array}$} & WHOLE & 895 & 792 & 843.5 \\
\hline 176 & & WHOLE & 912 & 886 & 899 \\
\hline 179 & \multirow{2}{*}{$\begin{array}{l}\text { Core } 46 \\
\text { Composite }\end{array}$} & WHOLE: & 916 & 884 & 900 \\
\hline 180 & & WHOLE & 941 & 979 & 960 \\
\hline \multicolumn{2}{|c|}{ Wirula k, acto digert. } & & \$III & $x+11$ & \%oritu \\
\hline 204 & $\begin{array}{l}\text { Core } 46 \\
\text { Composite }\end{array}$ & $\mathrm{DL}$ & 316 & $\cdots$ & 316 \\
\hline \multicolumn{2}{|c|}{ Golids: fision } & & 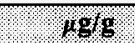 & $4 \mathrm{gg}$ & 195 \\
\hline 175 & \multirow{2}{*}{$\begin{array}{l}\text { Core } 45 \\
\text { Composite }\end{array}$} & WHOLE & 854 & 870 & 862 \\
\hline 176 & & WHOLE & 813 & 853 & 833 \\
\hline 179 & \multirow{2}{*}{$\begin{array}{l}\text { Core } 46 \\
\text { Composite }\end{array}$} & WHOLE & 852 & 848 & 850 \\
\hline 180 & & WHOLE & 957 & 885 & 921 \\
\hline \multicolumn{2}{|c|}{ Sollds, water digest } & & 1488 & $188 \%$ & 1818 \\
\hline 175 & \multirow{2}{*}{$\begin{array}{l}\text { Core } 45 \\
\text { Composite }\end{array}$} & WHOLE & 140 & 132 & 136 \\
\hline 176 & & WHOLE & 141 & 144 & 142.5 \\
\hline 179 & \multirow{2}{*}{$\begin{array}{l}\text { Core } 46 \\
\text { Composite }\end{array}$} & WHOLE: & 149 & 148 & 148.5 \\
\hline 180 & & WHOLE: & 149 & 148 & 148.5 \\
\hline
\end{tabular}

Note:

'Homogenization test sample 
Table B2-19. Tank 241-T-104 Analytical Results: Cobalt (ICP).

\begin{tabular}{|c|c|c|c|c|c|}
\hline 6. & 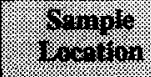 & 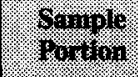 & 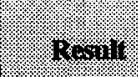 & 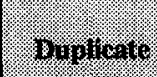 & 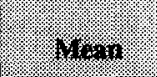 \\
\hline \multicolumn{2}{|c|}{ 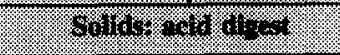 } & & . & 6 & (n) \\
\hline $147^{1}$ & \multirow[t]{2}{*}{$46: 2$} & WHOLE & 1.65 & 1.66 & $1.655^{\mathrm{QC}: 7}$ \\
\hline $146^{1}$ & & WHOLE & $<1.18$ & 1.4 & $<1.29^{\mathrm{QC}: 7,9}$ \\
\hline 175 & \multirow{2}{*}{$\begin{array}{l}\text { Core } 45 \\
\text { Composite }\end{array}$} & WHOLE & 1.36 & 1.44 & $1.4^{\mathrm{QC}: 7}$ \\
\hline 176 & & WHOLE & 1.8 & $<1.74$ & $<1.77^{\mathrm{QC}: 7}$ \\
\hline 179 & \multirow{2}{*}{$\begin{array}{l}\text { Core } 46 \\
\text { Composite }\end{array}$} & WHOLE & $<1.2$ & 2.04 & $<1.62^{\mathrm{QC}: 7,9}$ \\
\hline 180 & & WHOLE & $<1.19$ & 1.75 & $<1.47^{\mathrm{QC} \cdot 7,9}$ \\
\hline \multicolumn{2}{|c|}{ 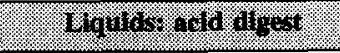 } & & $1 \%, 410$ & $1.611 \%$ & $6 \%$ \\
\hline 204 & $\begin{array}{l}\text { Core } 46 \\
\text { Composite }\end{array}$ & DL & 0.545 & -- & 0.545 \\
\hline \multicolumn{2}{|c|}{ Soly, row } & & 80 & 8 & 46 \\
\hline 175 & \multirow{2}{*}{$\begin{array}{l}\text { Core } 45 \\
\text { Composite }\end{array}$} & WHOLE & 10.3 & 11.7 & 11 \\
\hline 176 & & WHOLE & 14.6 & 12.1 & 13.35 \\
\hline 179 & \multirow{2}{*}{$\begin{array}{l}\text { Core } 46 \\
\text { Composite }\end{array}$} & WHOLE & $<9.46$ & $<9.48$ & $<9.47$ \\
\hline 180 & & WHOLE & $<9.42$ & $<9.39$ & $<9.405$ \\
\hline \multicolumn{2}{|c|}{ 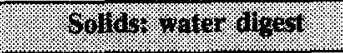 } & \% & $1 \%$ & 1989 & 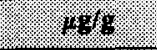 \\
\hline 175 & \multirow{2}{*}{$\begin{array}{l}\text { Core } 45 \\
\text { Composite }\end{array}$} & WHOLE & $<1.22$ & $<1.22$ & $<1.22^{\mathrm{QC}: 7}$ \\
\hline 176 & & WHOLE & $<1.22$ & $<1.22$ & $<1.22^{\mathrm{QC}: 7}$ \\
\hline 179 & \multirow{2}{*}{$\begin{array}{l}\text { Core } 46 \\
\text { Composite }\end{array}$} & WHOLE & $<1.22$ & $<1.22$ & $<1.22^{\mathrm{QC}: 7}$ \\
\hline 180 & & WHOLE & $<1.2$ & $<1.21$ & $<1.205^{\mathrm{QC}: 7}$ \\
\hline
\end{tabular}

Note:

${ }^{1}$ Homogenization test sample 
Table B2-20. Tank 241-T-104 Analytical Results: Copper (ICP).

\begin{tabular}{|c|c|c|c|c|c|}
\hline$\frac{9}{4}$ & $\frac{6}{203010}$ & (6) & 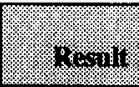 & gyplacuto & (1) \\
\hline \multicolumn{2}{|c|}{ 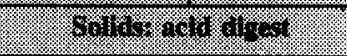 } & VI: & 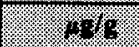 & (2.7. & (3) \\
\hline $147^{1}$ & \multirow[t]{2}{*}{ 46: 2} & WHOLE & 6.78 & 8.85 & $7.815^{\mathrm{QC}: 7,9}$ \\
\hline $146^{1}$ & & WHOLE & 7.45 & 6.32 & $6.885^{\mathrm{QC}: 7}$ \\
\hline 175 & \multirow{2}{*}{\begin{tabular}{|l|} 
Core 45 \\
Composite
\end{tabular}} & WHOLE & 11.9 & 11.4 & 11.65 \\
\hline 176 & & WHOLE & 13.7 & 13.1 & 13.4 \\
\hline 179 & \multirow{2}{*}{$\begin{array}{l}\text { Core } 46 \\
\text { Composite }\end{array}$} & WHOLE & 12.8 & 12.1 & $12.45^{\mathrm{QC}: 13}$ \\
\hline 180 & & WHOLE & 12.3 & 12.3 & \begin{tabular}{|l}
$12.3^{\mathrm{QC}: 13}$ \\
\end{tabular} \\
\hline \multicolumn{2}{|c|}{ 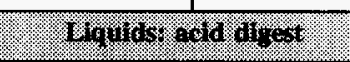 } & 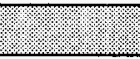 & 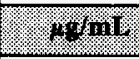 & $4 \%$ & . \\
\hline 204 & \begin{tabular}{|l|} 
Core 46 \\
Composite
\end{tabular} & $\mathrm{DL}$ & 4.61 & -- & 4.61 \\
\hline \multicolumn{2}{|c|}{ 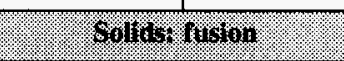 } & 4.8 & 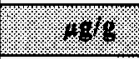 & $49 \%$ & $1.4 \%$ \\
\hline 175 & \multirow{2}{*}{$\begin{array}{l}\text { Core } 45 \\
\text { Composite }\end{array}$} & WHOLE & 77.9 & 77.2 & 77.55 \\
\hline 176 & & WHOLE & 52.6 & 48.8 & 50.7 \\
\hline 179 & \multirow{2}{*}{$\begin{array}{l}\text { Core } 46 \\
\text { Composite }\end{array}$} & WHOLE & 14.3 & 49.5 & $31.9^{\text {ec: } 7,9}$ \\
\hline 180 & & WHOLE & 42.9 & 44.4 & $43.65^{\mathrm{QC}: 6}$ \\
\hline \multicolumn{2}{|c|}{ Sollows rater aly tor } & 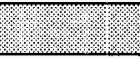 & $19 \%$ & 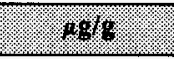 & 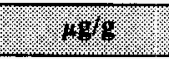 \\
\hline 175 & \multirow{2}{*}{$\begin{array}{l}\text { Core } 45 \\
\text { Composite }\end{array}$} & WHOLE & $<0.609$ & $<0.609$ & $<0.609^{\mathrm{OC:} 7}$ \\
\hline 176 & & WHOLE & $<0.61$ & $<0.612$ & $<0.611^{\mathrm{QC}: 7}$ \\
\hline 179 & \multirow{2}{*}{$\begin{array}{l}\text { Core } 46 \\
\text { Composite }\end{array}$} & WHOLE & $<0.61$ & $<0.611$ & $<0.6105^{\mathrm{Qc:7}}$ \\
\hline 180 & & WHOLE & $<0.601$ & $<0.605$ & $<0.603^{\mathrm{QC}: 7}$ \\
\hline
\end{tabular}

Note:

'Homogenization test sample 
Table B2-21. Tank 241-T-104 Analytical Results: Iron (ICP).

\begin{tabular}{|c|c|c|c|c|c|}
\hline (6) & 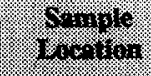 & $\frac{6+10}{4010}$ & 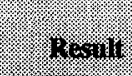 & 4,4010 & 4 \\
\hline \multicolumn{2}{|c|}{ ory } & (1): & $1 \%$ & 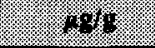 & $8 \%$ \\
\hline $147^{1}$ & \multirow[t]{2}{*}{$46: 2$} & WHOLE & 17,800 & 23,100 & $20,450^{\mathrm{QC}: 9}$ \\
\hline $146^{1}$ & & WHOLE & 13,800 & 14,800 & 14,300 \\
\hline 175 & \multirow{2}{*}{$\begin{array}{l}\text { Core } 45 \\
\text { Composite }\end{array}$} & WHOLE & 9,660 & 8,520 & 9,090 \\
\hline 176 & & WHOLE & 9,680 & 9,310 & 9,495 \\
\hline 179 & \multirow{2}{*}{$\begin{array}{l}\text { Core } 46 \\
\text { Composite }\end{array}$} & WHOLE & 8,540 & 8,300 & 8,420 \\
\hline 180 & & WHOLE & 9,140 & 8,980 & 9,060 \\
\hline \multicolumn{2}{|c|}{ 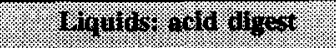 } & & 108410 & (3) & forin \\
\hline 204 & $\begin{array}{l}\text { Core } 46 \\
\text { Composite }\end{array}$ & DL & 1,520 & --- & $1,520^{\mathrm{Qc}: 13}$ \\
\hline \multicolumn{2}{|c|}{ 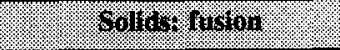 } & & 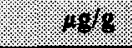 & \% & 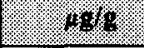 \\
\hline 175 & \multirow{2}{*}{$\begin{array}{l}\text { Core } 45 \\
\text { Composite }\end{array}$} & WHOLE & 9,410 & 10,100 & $9,755^{\mathrm{QC}: 10}$ \\
\hline 176 & & WHOLE & 8,960 & 9,350 & $9,155^{\text {QC:10 }}$ \\
\hline 179 & \multirow{2}{*}{$\begin{array}{l}\text { Core } 46 \\
\text { Composite }\end{array}$} & WHOLE & 8,200 & 7,920 & 8,060 \\
\hline 180 & & WHOLE & 8,640 & 8,130 & 8,385 \\
\hline \multicolumn{2}{|c|}{ 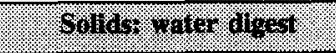 } & & . & 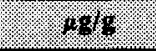 & (19) \\
\hline 175 & \multirow{2}{*}{$\begin{array}{l}\text { Core } 45 \\
\text { Composite }\end{array}$} & WHOLE & 61.7 & 68.9 & $65.3^{\mathrm{QC}: 10}$ \\
\hline 176 & & WHOLE & 83.6 & 103 & $93.3^{\mathrm{QC}: 9,10}$ \\
\hline 179 & \multirow{2}{*}{$\begin{array}{l}\text { Core } 46 \\
\text { Composite }\end{array}$} & WHOLE & 81.3 & 81.7 & $81.5^{\mathrm{QC}: 10}$ \\
\hline 180 & & WHOLE & 91.6 & 74.7 & $83.15^{\mathrm{QC}: 9,10}$ \\
\hline
\end{tabular}

Note:

${ }^{1}$ Homogenization test sample 
Table B2-22. Tank 241-T-104 Analytical Results: Lanthanum (ICP).

\begin{tabular}{|c|c|c|c|c|c|}
\hline 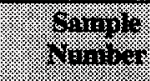 & Yimple & $\begin{array}{l}\text { Seraglo: } \\
\text { roption. }\end{array}$ & 49.8111 & proplisito. & y.8.n. \\
\hline \multicolumn{2}{|c|}{ Sollo $1 \mathrm{ar} \mathrm{al}=2$} & 2. & 406 & 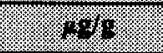 & 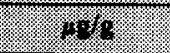 \\
\hline $147^{1}$ & \multirow[t]{2}{*}{ 46: 2} & WHOLE & $<2.05$ & $<2.08$ & $<2.065^{\mathrm{QC}: 4,7}$ \\
\hline $146^{1}$ & & WHOLE & $<2.06$ & $<2.08$ & $<2.07^{\mathrm{QC}: 4,7}$ \\
\hline 175 & \multirow{2}{*}{\begin{tabular}{|l|} 
Core 45 \\
Composite
\end{tabular}} & WHOLE & $<1.99$ & $<2.02$ & $<2.005^{\mathrm{QC}: 4}$ \\
\hline 176 & & WHOLE & $<2.88$ & $<3.05$ & $<2.965^{\mathrm{QC}: 4}$ \\
\hline 179 & \multirow{2}{*}{$\begin{array}{l}\text { Core } 46 \\
\text { Composite }\end{array}$} & WHOLE & $<2.1$ & $<2.08$ & $<2.09^{\mathrm{QC}: 4,7}$ \\
\hline 180 & & WHOLE & $<2.08$ & $<2.07$ & $<2.075^{\mathrm{QC}: 4,7}$ \\
\hline \multicolumn{2}{|c|}{ Irougr agd algert } & & H.णnI & 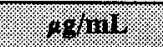 & $.65 \mathrm{nil}$ \\
\hline 204 & $\begin{array}{l}\text { Core } 46 \\
\text { Composite }\end{array}$ & DL & 0.21 & - & $0.21^{\mathrm{QC}: 4}$ \\
\hline \multicolumn{2}{|c|}{ Solialy ringun } & & $4.6 \%$ & 1848 & 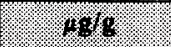 \\
\hline 175 & \multirow{2}{*}{$\begin{array}{l}\text { Core } 45 \\
\text { Composite }\end{array}$} & WHOLE & $<10.4$ & $<10.4$ & $<10.4^{Q C: 4}$ \\
\hline 176 & & WHOLE & $<10.4$ & $<10.4$ & $<10.4^{Q C: 4}$ \\
\hline 179 & \multirow{2}{*}{\begin{tabular}{|l} 
Core 46 \\
Composite
\end{tabular}} & WHOLE & $<9.96$ & $<9.98$ & $<9.97^{\mathrm{OC}: 4}$ \\
\hline 180 & & WHOLE & $<9.92$ & $<9.88$ & $<9.9^{\mathrm{QC}: 4}$ \\
\hline \multicolumn{2}{|c|}{ Solldar water digert } & & (2) 1818 & .986 & 4819 \\
\hline 175 & \multirow{2}{*}{$\begin{array}{l}\text { Core } 45 \\
\text { Composite }\end{array}$} & WHOLE & $<2.13$ & $<2.13$ & $<2.13^{\mathrm{QC}: 4}$ \\
\hline 176 & & WHOLE & $<2.13$ & $<2.14$ & $<2.135^{\mathrm{QC}: 4}$ \\
\hline 179 & \multirow{2}{*}{$\begin{array}{l}\text { Core } 46 \\
\text { Composite }\end{array}$} & WHOLE & $<2.13$ & $<2.14$ & $<2.135^{\mathrm{QC}: 4}$ \\
\hline 180 & & WHOLE & $<2.1$ & $<2.12$ & $<2.11^{\mathrm{QC}: 4,7}$ \\
\hline
\end{tabular}

Note:

'Homogenization test sample 
HNF-SD-WM-ER-372 Rev. 1

Table B2-23. Tank 241-T-104 Analytical Results: Lead (ICP).

\begin{tabular}{|c|c|c|c|c|c|}
\hline $\begin{array}{l}\text { Somple } \\
\text { Wuilose }\end{array}$ & Gamplo & Somplo & Tesillt & Bupliogte & Men \\
\hline \multicolumn{2}{|c|}{ 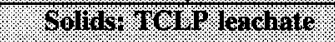 } & & Horim & $10 \%$ min & y. \\
\hline 199 & \multirow{2}{*}{$\begin{array}{l}\text { Core } 45 \\
\text { Composite }\end{array}$} & WHOLE & 5.09 & -- & 5.09 \\
\hline 196 & & WHOLE & $<0.39$ & $<0.39$ & $<0.39^{\mathrm{QC}: 4.7}$ \\
\hline \multicolumn{2}{|c|}{ Solins gad digest } & & 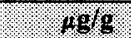 & .1948 & (2) 40 \\
\hline $147^{1}$ & \multirow[t]{2}{*}{$46: 2$} & WHOLE & 141 & 120 & $130.5^{\mathrm{QC}: 4,7}$ \\
\hline $146^{1}$ & & WHOLE & 148 & 67.5 & $107.75^{\mathrm{QC}: 4.7,9}$ \\
\hline 175 & \multirow{2}{*}{$\begin{array}{l}\text { Core } 45 \\
\text { Composite }\end{array}$} & WHOLE & 85.3 & 50.5 & $67.9^{\overline{Q C: 7,9,10}}$ \\
\hline 176 & & WHOLE & 42.3 & 40.3 & $41.3^{\mathrm{Qc}: 7,10}$ \\
\hline 179 & \multirow{2}{*}{$\begin{array}{l}\text { Core } 46 \\
\text { Composite }\end{array}$} & WHOLE & 28.5 & 28.5 & $28.5^{\mathrm{QC} .7}$ \\
\hline 180 & & WHOLE & 88.6 & 34.5 & $61.55^{0.7,12}$ \\
\hline \multicolumn{2}{|c|}{ Wifuids acid aigest } & 1 & Hetrif & 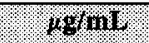 & $18 \% 911$ \\
\hline 204 & $\begin{array}{l}\text { Core } 46 \\
\text { Composite }\end{array}$ & $\mathrm{DL}$ & 1.58 & -- & $1.58^{\mathrm{QC}: 4}$ \\
\hline \multicolumn{2}{|c|}{ Solldst fusion } & & $19 \mathrm{~g} / \mathrm{g}$ & 1.96 & 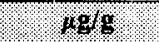 \\
\hline 175 & \multirow{2}{*}{$\begin{array}{l}\text { Core } 45 \\
\text { Composite }\end{array}$} & WHOLE & 46.6 & $<42$ & $<44.3^{\mathrm{QC}: 7.9}$ \\
\hline 176 & & WHOLE & 90.8 & $<42.2$ & $<66.5^{\mathrm{QC}: 7,9}$ \\
\hline 179 & \multirow{2}{*}{$\begin{array}{l}\text { Core } 46 \\
\text { Composite }\end{array}$} & WHOLE & $<38.8$ & 65.2 & $<52^{\mathrm{QC}: 7,9}$ \\
\hline 180 & & WHOLE & $<38.7$ & 43.3 & $<41^{\mathrm{QC}: 7,9}$ \\
\hline \multicolumn{2}{|c|}{ Solids w water digest } & & .1948 & 1096 & $.148 \mathrm{~g}$ \\
\hline 175 & \multirow{2}{*}{$\begin{array}{l}\text { Core } 45 \\
\text { Composite }\end{array}$} & WHOLE & $<8.63$ & $<8.63$ & $<8.63^{\mathrm{QC} 7}$ \\
\hline 176 & & WHOLE & $<8.64$ & $<8.67$ & $<8.655^{Q C: 7}$ \\
\hline 179 & \multirow{2}{*}{$\begin{array}{l}\text { Core } 46 \\
\text { Composite }\end{array}$} & WHOLE & $<8.64$ & $<8.65$ & $<8.645$ \\
\hline 180 & & WHOLE & $<8.51$ & $<8.57$ & $<8.54$ \\
\hline
\end{tabular}

Note:

'Homogenization test sample 
HNF-SD-WM-ER-372 Rev. 1

Table B2-24. Tank 241-T-104 Analytical Results: Magnesium (ICP).

\begin{tabular}{|c|c|c|c|c|c|}
\hline Sormine: & 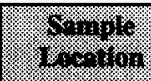 & 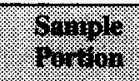 & (2. & 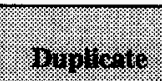 & 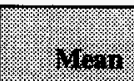 \\
\hline \multicolumn{2}{|c|}{ oolog rowow } & 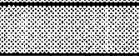 & 1.010 & 1040 & 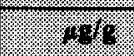 \\
\hline $147^{1}$ & \multirow[t]{2}{*}{ 46: 2} & WHOLE & 126 & 123 & $124.5^{\mathrm{QC:}:, 13}$ \\
\hline $146^{1}$ & & WHOLE & 122 & 103 & $112.5^{\mathrm{QC}: 7,13}$ \\
\hline 175 & \multirow{2}{*}{\begin{tabular}{|l|} 
Core 45 \\
Composite
\end{tabular}} & $\overline{\text { WHOLE }}$ & 102 & 90.2 & 96.1 \\
\hline 176 & & WHOLE & 111 & 118 & $114.5^{\overline{Q C} 7}$ \\
\hline 179 & \multirow{2}{*}{$\begin{array}{l}\text { Core } 46 \\
\text { Composite }\end{array}$} & WHOLE & 99.9 & 99.8 & $99.85^{\mathrm{QC}: 5,7}$ \\
\hline 180 & & WHOLE & 103 & 104 & $103.5^{\mathrm{QC}: 5,7}$ \\
\hline \multicolumn{2}{|c|}{ 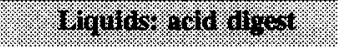 } & & : & (1.27) & 48 init \\
\hline 204 & $\begin{array}{l}\text { Core } 46 \\
\text { Composite }\end{array}$ & DL & 22.3 & -- & $22.3^{\mathrm{OC}: 7,8}$ \\
\hline \multicolumn{2}{|c|}{ 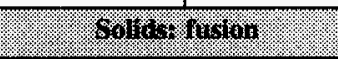 } & 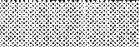 & 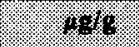 & 8\%: & 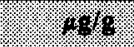 \\
\hline 175 & \multirow{2}{*}{$\begin{array}{l}\text { Core } 45 \\
\text { Composite }\end{array}$} & WHOLE & 267 & 131 & 199 \\
\hline 176 & & WHOLE & 125 & 123 & 124 \\
\hline 179 & \multirow{2}{*}{$\begin{array}{l}\text { Core } 46 \\
\text { Composite }\end{array}$} & WHOLE & 122 & 123 & $122.5^{\mathrm{QC}: 6,7}$ \\
\hline 180 & & WHOLE & 124 & 110 & $117^{\mathrm{QC:6,7}}$ \\
\hline \multicolumn{2}{|c|}{ Solldst wainer digest } & & 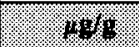 & .0848 & 4.88 \\
\hline 175 & \multirow{2}{*}{$\begin{array}{l}\text { Core } 45 \\
\text { Composite }\end{array}$} & WHOLE & 8.77 & 5.66 & 7.215 \\
\hline 176 & & WHOLE & 7.35 & 7.75 & 7.55 \\
\hline 179 & \multirow{2}{*}{\begin{tabular}{|l} 
Core 46 \\
Composite
\end{tabular}} & WHOLE & 4.4 & 4.68 & $4.54^{\mathrm{QC}: 5,9}$ \\
\hline 180 & & WHOLE & 5.23 & 4.62 & $4.925^{\mathrm{QC:5,9}}$ \\
\hline
\end{tabular}

Note:

${ }^{1}$ Homogenization test sample 
HNF-SD-WM-ER-372 Rev. 1

Table B2-25. Tank 241-T-104 Analytical Results: Manganese (ICP).

\begin{tabular}{|c|c|c|c|c|c|}
\hline oring & 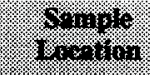 & W.1319 & 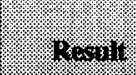 & 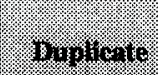 & 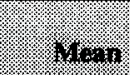 \\
\hline \multicolumn{2}{|c|}{ 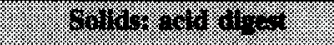 } & & $\%$ & $4 \%$ & 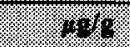 \\
\hline $147^{1}$ & \multirow[t]{2}{*}{ 46: 2} & WHOLE & 69.1 & 84.7 & $76.9^{\mathrm{QC}: 9}$ \\
\hline $146^{1}$ & & WHOLE & 53 & 53.7 & 53.35 \\
\hline 175 & \multirow{2}{*}{$\begin{array}{l}\text { Core } 45 \\
\text { Composite }\end{array}$} & WHOLE & 32.8 & 28.7 & 30.75 \\
\hline 176 & & WHOLE & 31.9 & 30.4 & 31.15 \\
\hline 179 & \multirow{2}{*}{$\begin{array}{l}\text { Core } 46 \\
\text { Composite }\end{array}$} & WHOLE & 29.1 & 28.4 & 28.75 \\
\hline 180 & & WHOLE & 32.6 & 30.8 & 31.7 \\
\hline \multicolumn{2}{|c|}{ 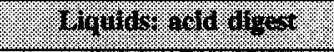 } & & H) & 41111 & \% \\
\hline 204 & $\begin{array}{l}\text { Core } 46 \\
\text { Composite }\end{array}$ & DL & 5.12 & --- & 5.12 \\
\hline \multicolumn{2}{|c|}{ 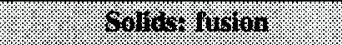 } & & 0.18 & $189 / 8$ & 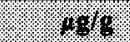 \\
\hline 175 & \multirow{2}{*}{$\begin{array}{l}\text { Core } 45 \\
\text { Composite }\end{array}$} & WHOLE & 64.1 & 64.4 & 64.25 \\
\hline 176 & & WHOLE & 57.8 & 59.5 & 58.65 \\
\hline 179 & \multirow{2}{*}{$\begin{array}{l}\text { Core } 46 \\
\text { Composite }\end{array}$} & WHOLE & 47.1 & 68.9 & $58^{\mathrm{QC}: 6.9}$ \\
\hline 180 & & WHOLE & 69.4 & 63.1 & 66.25 \\
\hline \multicolumn{2}{|c|}{ 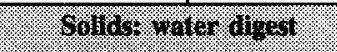 } & & $\%$ & 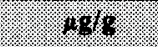 & 18,8 \\
\hline 175 & \multirow{2}{*}{$\begin{array}{l}\text { Core } 45 \\
\text { Composite }\end{array}$} & WHOLE & $<0.304$ & $<0.304$ & $<0.304$ \\
\hline 176 & & WHOLE & 0.395 & 0.401 & 0.398 \\
\hline 179 & \multirow{2}{*}{$\begin{array}{l}\text { Core } 46 \\
\text { Composite }\end{array}$} & WHOLE & 0.442 & 0.318 & 0.38 \\
\hline 180 & & WHOLE & 0.508 & 0.363 & 0.4355 \\
\hline
\end{tabular}

Note:

${ }^{1}$ Homogenization test sample 
Table B2-26. Tank 241-T-104 Analytical Results: Nickel (ICP).

\begin{tabular}{|c|c|c|c|c|c|}
\hline 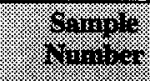 & C.moly & Sempila & $18=9.11$ & 8. & (10.20. \\
\hline \multicolumn{2}{|c|}{ 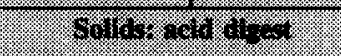 } & (1:-1: & $17 \%$ & 40 & 1010 \\
\hline $147^{1}$ & \multirow[t]{2}{*}{ 46: 2} & WHOLE & 9.35 & 10.1 & $9.725^{\mathrm{QC}: 7}$ \\
\hline $146^{1}$ & & WHOLE & 8.93 & 7.68 & $8.305^{\mathrm{QC}: 7}$ \\
\hline 175 & \multirow{2}{*}{$\begin{array}{l}\text { Core } 45 \\
\text { Composite }\end{array}$} & WHOLE & 10.8 & 11.3 & 11.05 \\
\hline 176 & & WHOLE & 9.01 & 7.9 & $8.455^{\mathrm{QC}: 7}$ \\
\hline 179 & \multirow{2}{*}{$\begin{array}{l}\text { Core } 46 \\
\text { Composite }\end{array}$} & WHOLE & 22.9 & 10.8 & $16.85^{\mathrm{QC}: 7,9}$ \\
\hline 180 & & WHOLE & 7.96 & 9.63 & $8.795^{\mathrm{QC}: 7}$ \\
\hline \multicolumn{2}{|c|}{ 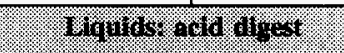 } & I: & $1.9 \% \mathrm{mil}$ & $1.98171 \%$ & $16 \%$ mil \\
\hline 204 & $\begin{array}{l}\text { Core } 46 \\
\text { Composite }\end{array}$ & DL & 1.61 & -- & $1.61^{\mathrm{QC}: 7}$ \\
\hline \multicolumn{2}{|c|}{ Solitis: rimion } & 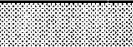 & $10 \%$ & 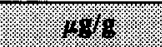 & 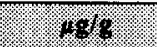 \\
\hline 175 & \multirow{2}{*}{$\begin{array}{l}\text { Core } 45 \\
\text { Composite }\end{array}$} & WHOLE & 11,100 & 7,930 & $9,515^{\text {QC:7,9 }}$ \\
\hline 176 & & WHOLE & 8,830 & 7,280 & $8,055^{\mathrm{QC}: 7}$ \\
\hline 179 & \multirow{2}{*}{\begin{tabular}{|l|} 
Core 46 \\
Composite
\end{tabular}} & WHOLE & 5,830 & 13,200 & $9,515^{\mathrm{OC}: 6,7,9}$ \\
\hline 180 & & WHOLE & 17,700 & 11,900 & $14,800^{\mathrm{eC}: 7,9}$ \\
\hline \multicolumn{2}{|c|}{ Solidis: yatar digest } & & 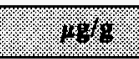 & $.4 \mathrm{~g}$ & $.4 \cdot 8$ \\
\hline 175 & \multirow{2}{*}{$\begin{array}{l}\text { Core } 45 \\
\text { Composite }\end{array}$} & WHOLE & $<1.83$ & $<1.83$ & $<1.83^{\mathrm{OC}: 7}$ \\
\hline 176 & & WHOLE & $<1.83$ & $<1.84$ & $<1.835^{Q \mathrm{QC}: 7}$ \\
\hline 179 & \multirow{2}{*}{$\begin{array}{l}\text { Core } 46 \\
\text { Composite }\end{array}$} & WHOLE & $<1.83$ & $<1.83$ & $<1.83^{\mathrm{QC}: 7}$ \\
\hline 180 & & WHOLE & $<1.8$ & $<1.81$ & $<1.805^{Q \mathrm{C}: 7}$ \\
\hline
\end{tabular}

Note:

${ }^{1}$ Homogenization test sample 
Table B2-27. Tank 241-T-104 Analytical Results: Phosphorus (ICP).

\begin{tabular}{|c|c|c|c|c|c|}
\hline (1) & $\frac{1}{2.13510}$ & 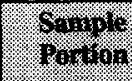 & $9+20,1113$ & 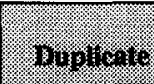 & 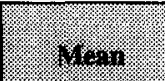 \\
\hline \multicolumn{2}{|c|}{ 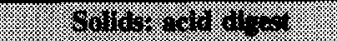 } & & 18.10 & 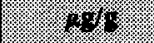 & $10 \%$ \\
\hline $147^{1}$ & \multirow[t]{2}{*}{ 46: 2} & WHOLE & 27,500 & 26,600 & $27,050^{Q c: 4,7}$ \\
\hline $146^{1}$ & & WHOLE & 27,100 & 28,100 & $27,600^{\mathrm{QC}: 4,7}$ \\
\hline 175 & \multirow{2}{*}{$\begin{array}{l}\text { Core } 45 \\
\text { Composite }\end{array}$} & WHOLE & 24,600 & 22,800 & $23,700^{\mathrm{eC}: 4}$ \\
\hline 176 & & WHOLE & 25,500 & 25,200 & $25,350^{\mathrm{QC}: 4}$ \\
\hline 179 & \multirow{2}{*}{$\begin{array}{l}\text { Core } 46 \\
\text { Composite }\end{array}$} & WHOLE & 23,700 & 23,000 & $23,350^{\mathrm{eC}: 4,7}$ \\
\hline 180 & & WHOLE & 23,400 & 23,800 & $23,600^{\mathrm{Qc}: 4.7}$ \\
\hline \multicolumn{2}{|c|}{ 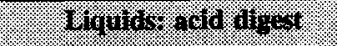 } & & 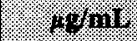 & $49.11 \%$ & \% 6 1110 \\
\hline 204 & $\begin{array}{l}\text { Core } 46 \\
\text { Composite }\end{array}$ & DL & 10,700 & --- & $10,700^{\mathrm{QC}: 4,7,13}$ \\
\hline \multicolumn{2}{|c|}{ \%olot ruston } & & 1.96 & $1 \%$ & 4.9 \\
\hline 175 & \multirow{2}{*}{$\begin{array}{l}\text { Core } 45 \\
\text { Composite }\end{array}$} & WHOLE & 26,300 & 26,100 & $26,200^{\mathrm{QC}: 4}$ \\
\hline 176 & & WHOLE & 27,700 & 27,100 & $27,400^{\mathrm{QC}: 4}$ \\
\hline 179 & \multirow{2}{*}{$\begin{array}{l}\text { Core } 46 \\
\text { Composite }\end{array}$} & WHOLE & 22,300 & 22,400 & $22,350^{\mathrm{QC}: 4,7}$ \\
\hline 180 & & WHOLE & 23,600 & 21,800 & $22,700^{\mathrm{QC}: 4,7}$ \\
\hline \multicolumn{2}{|c|}{ 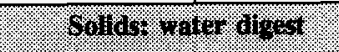 } & $1 \%$ & 89 & 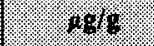 & 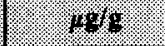 \\
\hline 175 & \multirow{2}{*}{$\begin{array}{l}\text { Core } 45 \\
\text { Composite }\end{array}$} & WHOLE & 6,000 & 5,750 & $5,875^{\mathrm{QC}: 4}$ \\
\hline 176 & & WHOLE & 6,470 & 6,550 & $6,510^{\mathrm{QC}: 4}$ \\
\hline 179 & \multirow{2}{*}{$\begin{array}{l}\text { Core } 46 \\
\text { Composite }\end{array}$} & WHOLE & 6,840 & 6,580 & $6,710^{\mathrm{QC}: 4,7}$ \\
\hline 180 & & WHOLE & 6,530 & 6,530 & $6,530^{\mathrm{ec}: 4,7}$ \\
\hline
\end{tabular}

Note:

${ }^{1}$ Homogenization test sample 
Table B2-28. Tank 241-T-104 Analytical Results: Potassium (ICP).

\begin{tabular}{|c|c|c|c|c|c|}
\hline 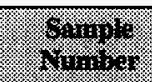 & 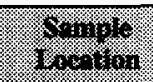 & $\begin{array}{l}\text { Somplo } \\
\text { Rortion }\end{array}$ & $8=-311$ & $9+13110.210$ & Than \\
\hline \multicolumn{2}{|c|}{ 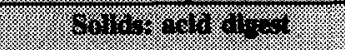 } & 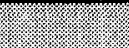 & 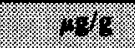 & 20 & 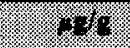 \\
\hline $147^{1}$ & \multirow[t]{2}{*}{ 46: 2} & WHOLE & 90.6 & 91.2 & 90.9 \\
\hline $146^{1}$ & & WHOLE & 94.1 & 88.7 & 91.4 \\
\hline 175 & \multirow{2}{*}{$\begin{array}{l}\text { Core } 45 \\
\text { Composite }\end{array}$} & WHOLE & 83.4 & 94.2 & $88.8^{\mathrm{QC}: 8}$ \\
\hline 176 & & WHOLE & 90.6 & 94.7 & 92.65 \\
\hline 179 & \multirow{2}{*}{$\begin{array}{l}\text { Core } 46 \\
\text { Composite }\end{array}$} & WHOLE & 84.9 & 89.6 & 87.25 \\
\hline 180 & & WHOLE & 83.8 & 91.1 & 87.45 \\
\hline \multicolumn{2}{|c|}{ 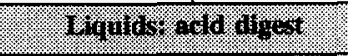 } & & ygrou & $48 / n$ & 19min \\
\hline 204 & $\begin{array}{l}\text { Core } 46 \\
\text { Composite }\end{array}$ & $\overline{\mathrm{DL}}$ & 74.7 & --- & 74.7 \\
\hline \multicolumn{2}{|c|}{ Gofiaks witer algest } & 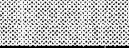 & 1090 & $184 \%$ & 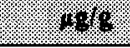 \\
\hline 175 & \multirow{2}{*}{$\begin{array}{l}\text { Core } 45 \\
\text { Composite }\end{array}$} & WHOLE & 34.6 & 32.1 & 33.35 \\
\hline 176 & & WHOLE & 36.6 & 38.2 & 37.4 \\
\hline 179 & \multirow{2}{*}{$\begin{array}{l}\text { Core } 46 \\
\text { Composite }\end{array}$} & WHOLE & 36.8 & 37.4 & 37.1 \\
\hline 180 & & WHOLE & 41.4 & 30.4 & 35.9 \\
\hline
\end{tabular}

Note:

${ }^{1}$ Homogenization test sample 
HNF-SD-WM-ER-372 Rev. 1

Table B2-29. Tank 241-T-104 Analytical Results: Selenium (ICP).

\begin{tabular}{|c|c|c|c|c|c|}
\hline Somolo & Tornolo & 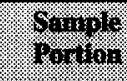 & Siesiar. & Minilionte & 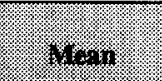 \\
\hline \multicolumn{2}{|c|}{ 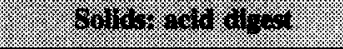 } & 1: & $1.2 \%$ & Hors & $19 \%$ \\
\hline $147^{1}$ & \multirow[t]{2}{*}{ 46: 2} & WHOLE & 34.5 & 30.4 & $32.45^{\mathrm{QC}: 4,7}$ \\
\hline $146^{1}$ & & WHOLE & 25.5 & 18.7 & $22.1^{\mathrm{QC}: 4,7,9}$ \\
\hline 175 & \multirow{2}{*}{$\begin{array}{l}\text { Core } 45 \\
\text { Composite }\end{array}$} & WHOLE & $<12.4$ & 15 & $<13.7$ \\
\hline 176 & & WHOLE & 28.4 & $<19$ & $<23.7^{\mathrm{QC} 9}$ \\
\hline 179 & \multirow{2}{*}{$\begin{array}{l}\text { Core } 46 \\
\text { Composite }\end{array}$} & WHOLE & $<13.1$ & $<12.9$ & $<13^{\mathrm{OC}: 4,7}$ \\
\hline 180 & & WHOLE & $<12.9$ & $<12.9$ & $<12.9^{\mathrm{QC}: 4,7}$ \\
\hline \multicolumn{2}{|c|}{ Giguidsy adid ayg-st. } & & $.804 \mathrm{~min}$ & $.1 \% \mathrm{ml}$ & 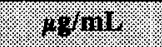 \\
\hline 204 & $\begin{array}{l}\text { Core } 46 \\
\text { Composite }\end{array}$ & $\overline{\mathrm{DL}}$ & 14.2 & -- & $14.2^{\mathrm{QC}: 4,13}$ \\
\hline \multicolumn{2}{|c|}{ ofliter troun } & & 1898 & 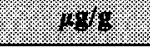 & 19818 \\
\hline 175 & \multirow{2}{*}{$\begin{array}{l}\text { Core } 45 \\
\text { Composite }\end{array}$} & WHOLE & $<64.6$ & $<64.7$ & $<64.65^{\mathrm{QC}: 7}$ \\
\hline 176 & & WHOLE & $<65.1$ & $<65.1$ & $<65.1^{\mathrm{QC}: 7}$ \\
\hline 179 & \multirow{2}{*}{\begin{tabular}{|l|} 
Core 46 \\
Composite
\end{tabular}} & WHOLE & $<70.2$ & $<70.4$ & $<70.3^{\mathrm{QC}: 4}$ \\
\hline 180 & & WHOLE & $<69.9$ & $<69.7$ & $<69.8^{\mathrm{QC}: 4}$ \\
\hline \multicolumn{2}{|c|}{ 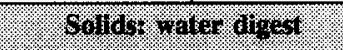 } & & 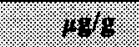 & 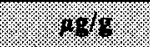 & 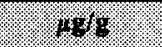 \\
\hline 175 & \multirow{2}{*}{$\begin{array}{l}\text { Core } 45 \\
\text { Composite }\end{array}$} & WHOLE & $<13.3$ & $<13.3$ & $<13.3^{\mathrm{QC}: 4,7}$ \\
\hline 176 & & WHOLE & $<13.3$ & $<13.4$ & $<13.35^{\mathrm{QC}: 4,7}$ \\
\hline 179 & \multirow{2}{*}{$\begin{array}{l}\text { Core } 46 \\
\text { Composite }\end{array}$} & WHOLE & $<13.3$ & $<13.3$ & $<13.3^{\mathrm{QC}: 4,7}$ \\
\hline 180 & & WHOLE & $<13.1$ & $<13.2$ & $<13.15^{\mathrm{QC}-4,7}$ \\
\hline
\end{tabular}

Note:

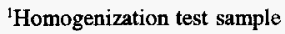


HNF-SD-WM-ER-372 Rev. 1

Table B2-30. Tank 241-T-104 Analytical Results: Silicon (ICP).

\begin{tabular}{|c|c|c|c|c|c|}
\hline 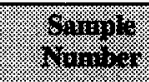 & 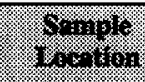 & Qminit & $1+2+11$ & $1 \% 31 \%$ & $4 \times$ \\
\hline \multicolumn{2}{|c|}{$4031 \%$} & & 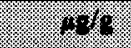 & 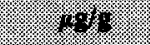 & 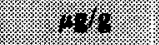 \\
\hline $147^{1}$ & \multirow[t]{2}{*}{ 46: 2} & WHOLE & 1,910 & 1,120 & $1,515^{\mathrm{QC}: 4,8,9}$ \\
\hline $146^{1}$ & & WHOLE & 1,370 & 1,100 & $1,235^{\mathrm{QC}: 4,8,9}$ \\
\hline 175 & \multirow{2}{*}{$\begin{array}{l}\text { Core } 45 \\
\text { Composite }\end{array}$} & WHOLE & 552 & 780 & $666^{\mathrm{QC}: 7,8,9}$ \\
\hline 176 & & WHOLE & 1,170 & 981 & $1,075.5^{\mathrm{QC}: 8,1 \mathrm{C}}$ \\
\hline 179 & \multirow{2}{*}{$\begin{array}{l}\text { Core } 46 \\
\text { Composite }\end{array}$} & WHOLE & 1,200 & 1,110 & $1,155^{\mathrm{Qc}: 8}$ \\
\hline 180 & & WHOLE & 1,170 & 1,170 & $1,170^{\mathrm{QC}: 8}$ \\
\hline \multicolumn{2}{|c|}{ 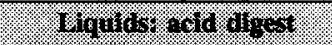 } & & 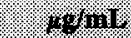 & $4.6 / 111$ & $\% 8111$ \\
\hline 204 & $\begin{array}{l}\text { Core } 46 \\
\text { Composite }\end{array}$ & DL & 631 & --- & $631^{\mathrm{QC}: 8,13}$ \\
\hline \multicolumn{2}{|c|}{ Wolys rigury. } & & 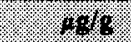 & 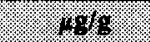 & 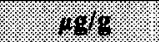 \\
\hline 175 & \multirow{2}{*}{$\begin{array}{l}\text { Core } 45 \\
\text { Composite }\end{array}$} & WHOLE & 6,770 & 7,160 & 6,965 \\
\hline 176 & & WHOLE & 6,270 & 6,590 & 6,430 \\
\hline 179 & \multirow{2}{*}{$\begin{array}{l}\text { Core } 46 \\
\text { Composite }\end{array}$} & WHOLE & 6,300 & 6,280 & 6,290 \\
\hline 180 & & WHOLE & 6,420 & 6,330 & 6,375 \\
\hline \multicolumn{2}{|c|}{ 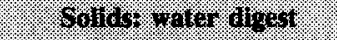 } & & $\% \%$ & 6818 & $4 \% 1 \%$ \\
\hline 175 & \multirow{2}{*}{$\begin{array}{l}\text { Core } 45 \\
\text { Composite }\end{array}$} & WHOLE & 170 & 160 & $165^{\mathrm{QC}: 7}$ \\
\hline 176 & & WHOLE & 154 & 171 & $162.5^{\mathrm{QC}: 7}$ \\
\hline 179 & \multirow{2}{*}{$\begin{array}{l}\text { Core } 46 \\
\text { Composite }\end{array}$} & WHOLE & 190 & 157 & $173.5^{\mathrm{QC}: 7,13}$ \\
\hline 180 & & WHOLE & 174 & 160 & $167^{\mathrm{QC}: 7}$ \\
\hline
\end{tabular}

Note:

${ }^{1}$ Homogenization test sample 
Table B2-31. Tank 241-T-104 Analytical Results: Silver (ICP).

\begin{tabular}{|c|c|c|c|c|c|}
\hline Manale & 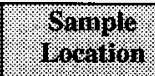 & ogrovo & Minsiniti & Bujlicate. & Yean \\
\hline \multicolumn{2}{|c|}{ 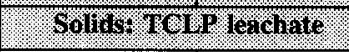 } & 1.. & . $48.1 \mathrm{mil}$ & ming & 140101 \\
\hline 199 & \multirow{2}{*}{$\begin{array}{l}\text { Core } 45 \\
\text { Composite }\end{array}$} & WHOLE & 0.0688 & $\cdots$ & 0.0688 \\
\hline 196 & & WHOLE & $<0.045$ & $<0.045$ & $<0.045^{\mathrm{QC}: 4,7}$ \\
\hline \multicolumn{2}{|c|}{ 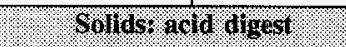 } & & 1096 & $148 / \mathrm{g}$ & 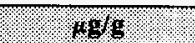 \\
\hline $147^{1}$ & \multirow[t]{2}{*}{$46: 2$} & WHOLE & $<0.976$ & $<0.99$ & $<0.983^{\mathrm{QC}: 4,7,8,10}$ \\
\hline $146^{1}$ & & WHOLE & $<0.983$ & $<0.991$ & $<0.987^{\mathrm{QC}: 4,7.8,10}$ \\
\hline 175 & \multirow{2}{*}{$\begin{array}{l}\text { Core } 45 \\
\text { Composite }\end{array}$} & WHOLE & $<0.947$ & $<0.96$ & $<0.9535^{\mathrm{QC}: 8,10}$ \\
\hline 176 & & WHOLE & $<1.37$ & $<1.45$ & $<1.41^{\mathrm{QC}: 7,8,10}$ \\
\hline 179 & \multirow{2}{*}{$\begin{array}{l}\text { Core } 46 \\
\text { Composite }\end{array}$} & WHOLE & $<0.998$ & $<0 . \overline{988}$ & $<0.993^{\mathrm{QC}: 8,10}$ \\
\hline 180 & & WHOLE & $<0.988$ & $<0.984$ & $<0.986^{\mathrm{QC}: 8,10}$ \\
\hline \multicolumn{2}{|c|}{ Urifuist acid digest } & & .8910 & $1 \% / \mathrm{mL}$ & $10 / \mathrm{mi}$ \\
\hline 204 & $\begin{array}{l}\text { Core } 46 \\
\text { Composite }\end{array}$ & DL & $<0.1$ & -- & $<0.1^{\mathrm{QC}: 4}$ \\
\hline \multicolumn{2}{|c|}{ Solids fision. } & & 1989 & 646 & 198 \\
\hline 175 & \multirow{2}{*}{$\begin{array}{l}\text { Core } 45 \\
\text { Composite }\end{array}$} & WHOLE & $<4.93$ & $<4.94$ & $<4.935$ \\
\hline 176 & & WHOLE & 6.4 & $<4.97$ & $<5.685^{\mathrm{QC:9}}$ \\
\hline 179 & \multirow{2}{*}{$\begin{array}{l}\text { Core } 46 \\
\text { Composite }\end{array}$} & WHOLE & $<4.48$ & $<4.49$ & $<4.485^{\mathrm{QC}: 47}$ \\
\hline 180 & & WHOLE & $<4.46$ & $<4.45$ & $<4.455^{\mathrm{QC}: 4.7}$ \\
\hline \multicolumn{2}{|c|}{ Solids water digest } & & 498 & $1 \%$ & $18 \%$ \\
\hline 175 & \multirow{2}{*}{$\begin{array}{l}\text { Core } 45 \\
\text { Composite }\end{array}$} & WHOLE & 2.51 & $<1.01$ & $<1.76^{0 C 7.9}$ \\
\hline 176 & & WHOLE & $<1.02$ & $<1.02$ & $<1.02^{\mathrm{QC} 7}$ \\
\hline 179 & \multirow{2}{*}{$\begin{array}{l}\text { Core } 46 \\
\text { Composite }\end{array}$} & WHOLE & $<1.02$ & $<1.02$ & $<1.02^{\mathrm{QC} \cdot 7}$ \\
\hline 180 & & WHOLE & $<1$ & $<1.01$ & $<1.005^{\mathrm{QC} .7}$ \\
\hline
\end{tabular}

Note:

${ }^{'}$ Homogenization test sample 
HNF-SD-WM-ER-372 Rev. 1

Table B2-32. Tank 241-T-104 Analytical Results: Sodium (ICP).

\begin{tabular}{|c|c|c|c|c|c|}
\hline $\begin{array}{l}\text { sinngle: } \\
\text { tromior. }\end{array}$ & 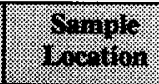 & $\begin{array}{l}\text { Sarayple } \\
\text { Torofion }\end{array}$ & $16 \sin$ & (1) & 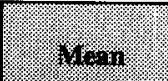 \\
\hline \multicolumn{2}{|c|}{ (6) } & 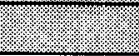 & (3) & 1. 14 & 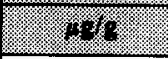 \\
\hline $147^{1}$ & \multirow[t]{2}{*}{ 46: 2} & WHOLE & 72,900 & 69,300 & $71,100^{\mathrm{eC}: 8}$ \\
\hline $146^{1}$ & & WHOLE & 68,800 & 69,600 & $69,200^{\mathrm{QC}: 8}$ \\
\hline 175 & \multirow{2}{*}{\begin{tabular}{|l|} 
Core 45 \\
Composite
\end{tabular}} & WHOLE & 65,100 & 59,600 & $62,350^{\mathrm{QC}: 8}$ \\
\hline 176 & & WHOLE & 72,200 & 70,200 & $71,200^{\mathrm{QC}: 8}$ \\
\hline 179 & \multirow{2}{*}{$\begin{array}{l}\text { Core } 46 \\
\text { Composite }\end{array}$} & WHOLE & 63,600 & 61,700 & $62,650^{\mathrm{QC}: 4,8}$ \\
\hline 180 & & WHOLE & 61,600 & 62,000 & $61,800^{\mathrm{QC}: 4,8}$ \\
\hline \multicolumn{2}{|c|}{ Migures achd alget } & & 4\%/mit. & (2. & $y \mathrm{~min}$ \\
\hline 204 & $\begin{array}{l}\text { Core } 46 \\
\text { Composite }\end{array}$ & $\mathrm{DL}$ & 55,400 & --- & $55,400^{\mathrm{QC}: 4,8,13}$ \\
\hline \multicolumn{2}{|c|}{ 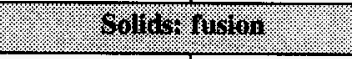 } & & (1) & $\int .149$ & 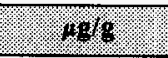 \\
\hline 175 & \multirow{2}{*}{$\begin{array}{l}\text { Core } 45 \\
\text { Composite }\end{array}$} & WHOLE & 63,800 & 65,100 & 64,450 \\
\hline 176 & & WHOLE & 61,700 & 62,700 & 62,200 \\
\hline 179 & \multirow{2}{*}{$\begin{array}{l}\text { Core } 46 \\
\text { Composite }\end{array}$} & WHOLE & 60,800 & 60,700 & $60,750^{\mathrm{QC}: 4,10}$ \\
\hline 180 & & WHOLE & 61,700 & 59,900 & $60,800^{\mathrm{eC}: 4,10}$ \\
\hline \multicolumn{2}{|c|}{ Soldor. want digect? } & & 190 & 996 & 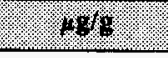 \\
\hline 175 & \multirow{2}{*}{$\begin{array}{l}\text { Core } 45 \\
\text { Composite }\end{array}$} & WHOLE & 45,100 & 43,900 & 44,500 \\
\hline 176 & & WHOLE & 46,200 & 46,800 & 46,500 \\
\hline 179 & \multirow{2}{*}{$\begin{array}{l}\text { Core } 46 \\
\text { Composite }\end{array}$} & WHOLE & 48,400 & 47,100 & 47,750 \\
\hline 180 & & WHOLE & 47,500 & 47,100 & 47,300 \\
\hline
\end{tabular}

Note:

${ }^{1}$ Homogenization test sample 
Table B2-33. Tank 241-T-104 Analytical Results: Strontium (ICP).

\begin{tabular}{|c|c|c|c|c|c|}
\hline 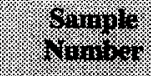 & 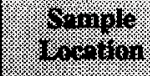 & 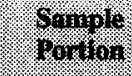 & gevilin & 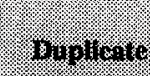 & U. \\
\hline \multicolumn{2}{|c|}{ 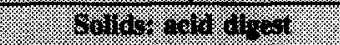 } & & $6 \%$ & 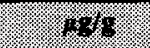 & 40 \\
\hline $147^{1}$ & \multirow[t]{2}{*}{ 46: 2} & WHOLE & 126 & 121 & $123.5^{\mathrm{QC}: 4,7}$ \\
\hline $146^{1}$ & & WHOLE & 118 & 121 & $119.5^{\mathrm{QC}: 4,7}$ \\
\hline 175 & \multirow{2}{*}{$\begin{array}{l}\text { Core } 45 \\
\text { Composite }\end{array}$} & WHOLE & 92.1 & 82.1 & $87.1^{Q C: 4}$ \\
\hline 176 & & WHOLE & 97.8 & 94.8 & $96.3^{Q C / 4}$ \\
\hline 179 & \multirow{2}{*}{$\begin{array}{l}\text { Core } 46 \\
\text { Composite }\end{array}$} & WHOLE & 100 & 95.6 & $97.8^{\mathrm{QC} 4,7}$ \\
\hline 180 & & WHOLE & 105 & 107 & $106^{\mathrm{QC}: 4,7}$ \\
\hline \multicolumn{2}{|c|}{ 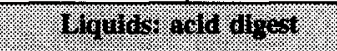 } & & 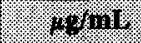 & 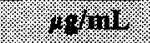 & \% \\
\hline 204 & $\begin{array}{l}\text { Core } 46 \\
\text { Composite }\end{array}$ & DL & 13.8 & --- & $13.8^{\mathrm{QC}: 4,7}$ \\
\hline \multicolumn{2}{|c|}{ Oof } & & $\%$ & 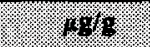 & 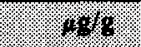 \\
\hline 175 & \multirow{2}{*}{$\begin{array}{l}\text { Core } 45 \\
\text { Composite }\end{array}$} & WHOLE & 98.4 & 98 & $98.2^{\mathrm{QC}: 4}$ \\
\hline 176 & & WHOLE & 90 & 95.5 & $92.75^{\mathrm{QC}: 4}$ \\
\hline 179 & \multirow{2}{*}{$\begin{array}{l}\text { Core } 46 \\
\text { Composite }\end{array}$} & WHOLE & 99.9 & 99.3 & $99.6^{\text {QC:4.6.7 }}$ \\
\hline 180 & & WHOLE & 107 & 105 & $106^{\mathrm{ec}: 4.6 .7}$ \\
\hline \multicolumn{2}{|c|}{ 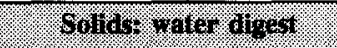 } & & $18 \%$ & 98 & 148 \\
\hline 175 & \multirow{2}{*}{$\begin{array}{l}\text { Core } 45 \\
\text { Composite }\end{array}$} & WHOLE & 1.46 & 1.07 & $1.265^{\mathrm{QC}: 4}$ \\
\hline 176 & & WHOLE & 1.26 & 1.54 & $1.4^{\mathrm{QC}: 4}$ \\
\hline 179 & \multirow{2}{*}{$\begin{array}{l}\text { Core } 46 \\
\text { Composite }\end{array}$} & WHOLE & 0.925 & 0.931 & $0.928^{\mathrm{QC}: 4.7}$ \\
\hline 180 & & WHOLE & 1.23 & 0.934 & $1.082^{\mathrm{QC}: 4,7,9}$ \\
\hline
\end{tabular}

Note:

${ }^{1}$ Homogenization test sample 
HNF-SD-WM-ER-372 Rev. 1

Table B2-34. Tank 241-T-104 Analytical Results: Sulfur (ICP).

\begin{tabular}{|c|c|c|c|c|c|}
\hline 3.111310 & (xingos & 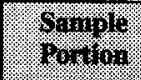 & S & 401316410 & 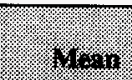 \\
\hline \multicolumn{2}{|c|}{ 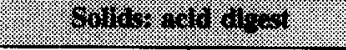 } & ? & $3 \%$ & 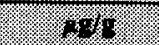 & 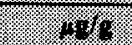 \\
\hline $147^{1}$ & \multirow[t]{2}{*}{ 46: 2} & WHOLE & 1,180 & 1,100 & $1,140^{\mathrm{OC}: 4,7}$ \\
\hline $146^{1}$ & & WHOLE & 1,090 & 1,100 & $1,095^{\mathrm{QC:}: 4}$ \\
\hline 175 & \multirow{2}{*}{$\begin{array}{l}\text { Core } 45 \\
\text { Composite }\end{array}$} & WHOLE & 1,310 & 1,180 & $1,245^{\mathrm{QC}: 4}$ \\
\hline 176 & & WHOLE & 1,370 & 1,320 & $1,345^{\mathrm{QC}: 4}$ \\
\hline 179 & \multirow{2}{*}{$\begin{array}{l}\text { Core } 46 \\
\text { Composite }\end{array}$} & WHOLE & 1,270 & 1,260 & $1,265^{\mathrm{QC:4,7}}$ \\
\hline 180 & & WHOLE & 1,230 & 1,270 & $1,250^{\mathrm{QC:4,7}}$ \\
\hline \multicolumn{2}{|c|}{ 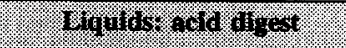 } & & $\% 1 \% 1 \%$ & 49111 & 1\%1n \\
\hline 204 & $\begin{array}{l}\text { Core } 46 \\
\text { Composite }\end{array}$ & $\mathrm{DL}$ & 1,700 & & 1,700 \\
\hline \multicolumn{2}{|c|}{ 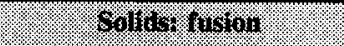 } & & 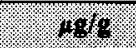 & $4 \%$ & 46 \\
\hline 175 & \multirow{2}{*}{$\begin{array}{l}\text { Core } 45 \\
\text { Composite }\end{array}$} & WHOLE & 1,290 & 1,320 & $1,305^{\mathrm{QC}: 4}$ \\
\hline 176 & & WHOLE & 1,270 & 1,310 & $1,290^{\mathrm{QC}: 4}$ \\
\hline 179 & \multirow{2}{*}{$\begin{array}{l}\text { Core } 46 \\
\text { Composite }\end{array}$} & WHOLE & 1,230 & 1,230 & $1,230^{\mathrm{QC}: 4,7}$ \\
\hline 180 & & WHOLE & 1,280 & 1,200 & $1,240^{\mathrm{QC}: 4,7}$ \\
\hline \multicolumn{2}{|c|}{ 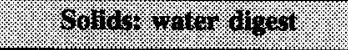 } & & 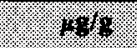 & 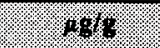 & (8) \\
\hline 175 & \multirow{2}{*}{$\begin{array}{l}\text { Core } 45 \\
\text { Composite }\end{array}$} & WHOLE & 1,270 & 1,200 & $1,235^{\mathrm{QC}: 4}$ \\
\hline 176 & & WHOLE & 1,310 & 1,310 & $1,310^{\mathrm{QC}: 4}$ \\
\hline 179 & \multirow{2}{*}{$\begin{array}{l}\text { Core } 46 \\
\text { Composite }\end{array}$} & WHOLE & 1,320 & 1,300 & $1,310^{\mathrm{QC}: 4}$ \\
\hline 180 & & WHOLE & 1,280 & 1,270 & $1,275^{\mathrm{QC}: 4}$ \\
\hline
\end{tabular}

Note:

${ }^{1}$ Homogenization test sample 
Table B2-35. Tank 241-T-104 Analytical Results: Tin (ICP).

\begin{tabular}{|c|c|c|c|c|c|}
\hline Siamples: & $\begin{array}{l}\text { Gomplo } \\
\text { gerotion. }\end{array}$ & $\begin{array}{l}\text { Sompre } \\
\text { Romtion }\end{array}$ & rosing & mingliono & (2. $14=$ \\
\hline \multicolumn{2}{|c|}{ 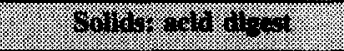 } & & 40 & 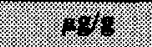 & 8.6 \\
\hline $147^{1}$ & \multirow[t]{2}{*}{ 46: 2} & WHOLE & 15.4 & 15.8 & $15.6^{\mathrm{QC}: 4,5}$ \\
\hline $146^{1}$ & & WHOLE & 18.1 & 14.1 & $16.1^{\mathrm{QC}-4,5,9}$ \\
\hline 175 & \multirow{2}{*}{\begin{tabular}{|l|} 
Core 45 \\
Composite
\end{tabular}} & WHOLE & 10.6 & 9.37 & $9.985^{\mathrm{QC}: 4}$ \\
\hline 176 & & WHOLE & 13.2 & 16.1 & $14.65^{\mathrm{QC}: 4}$ \\
\hline 179 & \multirow{2}{*}{$\begin{array}{l}\text { Core } 46 \\
\text { Composite }\end{array}$} & WHOLE & 10.8 & 10.2 & $10.5^{\mathrm{QC}: 4,5}$ \\
\hline 180 & & WHOLE & 11 & 11.8 & $11.4^{\mathrm{QC}: 4,5}$ \\
\hline \multicolumn{2}{|c|}{ 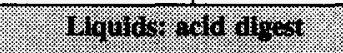 } & (3): & 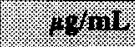 & 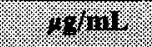 & (- \\
\hline 204 & $\begin{array}{l}\text { Core } 46 \\
\text { Composite }\end{array}$ & $\mathrm{DL}$ & 1.78 & -- & $1.78^{\mathrm{QC}: 4}$ \\
\hline \multicolumn{2}{|c|}{ 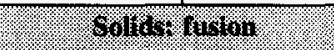 } & & 186 & 1484 & 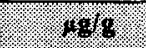 \\
\hline 175 & \multirow{2}{*}{$\begin{array}{l}\text { Core } 45 \\
\text { Composite }\end{array}$} & WHOLE & 16.8 & 17.3 & $17.05^{\mathrm{QC}: 4}$ \\
\hline 176 & & WHOLE & 16.1 & 19.7 & $17.9^{\mathrm{QC} \cdot 4}$ \\
\hline 179 & \multirow{2}{*}{\begin{tabular}{|l} 
Core 46 \\
Composite
\end{tabular}} & WHOLE & $<8.96$ & $<8.98$ & $<8.97^{\mathrm{QC}: 4}$ \\
\hline 180 & & WHOLE & $<8.93$ & $<8.89$ & $<8.91^{\mathrm{OC}: 4}$ \\
\hline \multicolumn{2}{|c|}{ 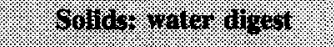 } & & 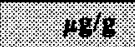 & 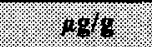 & . \\
\hline 175 & \multirow{2}{*}{$\begin{array}{l}\text { Core } 45 \\
\text { Composite }\end{array}$} & WHOLE & $<1.62$ & $<1.62$ & $<1.62^{\mathrm{QC}: 4}$ \\
\hline 176 & & WHOLE & $<1.63$ & $<1.63$ & $<1.63^{\mathrm{QC}: 4}$ \\
\hline 179 & \multirow{2}{*}{\begin{tabular}{|l|} 
Core 46 \\
Composite
\end{tabular}} & WHOLE & $<1.63$ & $<1.63$ & $<1.63^{\mathrm{QC}: 4}$ \\
\hline 180 & & WHOLE & $<1.6$ & $<1.61$ & $<1.605^{\mathrm{QC}: 4}$ \\
\hline
\end{tabular}

Note:

'Homogenization test sample 
HNF-SD-WM-ER-372 Rev. 1

Table B2-36. Tank 241-T-104 Analytical Results: Titanium (ICP).

\begin{tabular}{|c|c|c|c|c|c|}
\hline 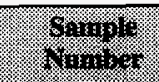 & 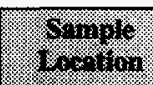 & 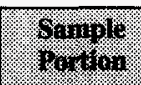 & 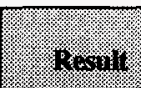 & ingizicito & 1. \\
\hline \multicolumn{2}{|c|}{ 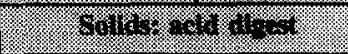 } & 4.8 & 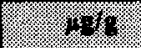 & 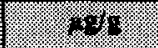 & l. \\
\hline $147^{1}$ & \multirow[t]{2}{*}{ 46: 2} & WHOLE & 18.7 & 16.3 & $17.5^{\mathrm{CQ}: 7}$ \\
\hline $146^{1}$ & & WHOLE & 16.7 & 16 & $16.35^{\mathrm{QC}: 7}$ \\
\hline 175 & \multirow{2}{*}{$\begin{array}{l}\text { Core } 45 \\
\text { Composite }\end{array}$} & WHOLE & 5.46 & 4.98 & 5.22 \\
\hline 176 & & WHOLE & 4.09 & 4.07 & 4.08 \\
\hline 179 & \multirow{2}{*}{$\begin{array}{l}\text { Core } 46 \\
\text { Composite }\end{array}$} & WHOLE & 4.44 & 4.01 & 4.225 \\
\hline 180 & & WHOLE & 4.46 & 4.98 & 4.72 \\
\hline \multicolumn{2}{|c|}{ 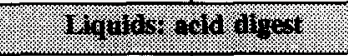 } & 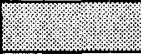 & 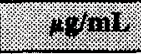 & f. & Hinu \\
\hline 204 & $\begin{array}{l}\text { Core } 46 \\
\text { Composite }\end{array}$ & DL & 0.995 & --- & $0.995^{0 C: 13}$ \\
\hline \multicolumn{2}{|c|}{ 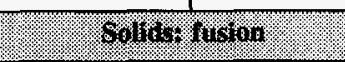 } & (1: & 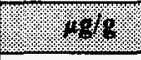 & $1.9 \%$ & 1.418 \\
\hline 175 & \multirow{2}{*}{$\begin{array}{l}\text { Core } 45 \\
\text { Composite }\end{array}$} & WHOLE & 5.64 & 11.7 & $8.67^{\mathrm{QC}: 7,9}$ \\
\hline 176 & & WHOLE & 10.2 & 9.84 & $10.02^{\mathrm{QC}: 7}$ \\
\hline 179 & \multirow{2}{*}{$\begin{array}{l}\text { Core } 46 \\
\text { Composite }\end{array}$} & WHOLE & 6.7 & 18.4 & $12.55^{\mathrm{QC}: 8}$ \\
\hline 180 & & WHOLE & 7.04 & 7.82 & 7.43 \\
\hline \multicolumn{2}{|c|}{ Soldory rater ligest } & & 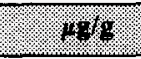 & 968 & 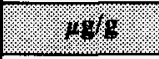 \\
\hline 175 & \multirow{2}{*}{$\begin{array}{l}\text { Core } 45 \\
\text { Composite }\end{array}$} & WHOLE & $<0.507$ & $<0.507$ & $<0.507^{\text {QC:7 }}$ \\
\hline 176 & & WHOLE & $<0.508$ & $<0.51$ & $<0.509^{\mathrm{QC}: 7}$ \\
\hline 179 & \multirow{2}{*}{\begin{tabular}{|l} 
Core 46 \\
Composite
\end{tabular}} & WHOLE & $<0.508$ & $<0.509$ & $<0.5085$ \\
\hline 180 & & WHOLE & $<0.5$ & $<0.504$ & $<0.502^{\mathrm{QC}: 7}$ \\
\hline
\end{tabular}

Note:

${ }^{1}$ Homogenization test sample 
Table B2-37. Tank 241-T-104 Analytical Results: Zinc (ICP).

\begin{tabular}{|c|c|c|c|c|c|}
\hline $\begin{array}{l}\text { Somple: } \\
\text { sinnot }\end{array}$ & $\begin{array}{l}\text { Complo } \\
\text { Sestion }\end{array}$ & $\begin{array}{l}\text { Somigle } \\
\text { Pootron }\end{array}$ & 196911 & 14initon= & y. \\
\hline \multicolumn{2}{|c|}{ 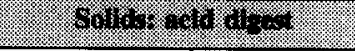 } & (3) & 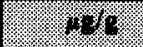 & (1. & \%or \\
\hline $147^{1}$ & \multirow[t]{2}{*}{ 46: 2} & WHOLE & 33.5 & 46.2 & $39.85^{\text {QC:7,9 }}$ \\
\hline $146^{1}$ & & WHOLE & 24.8 & 23.8 & $24.3^{\mathrm{OC} 7}$ \\
\hline 175 & \multirow{2}{*}{$\begin{array}{l}\text { Core } 45 \\
\text { Composite }\end{array}$} & WHOLE & 21 & 26 & $23.5^{\mathrm{QC}: 7,9}$ \\
\hline 176 & & WHOLE & 30.6 & 20.5 & $25.55^{\mathrm{QC}: 7,9}$ \\
\hline 179 & \multirow{2}{*}{$\begin{array}{l}\text { Core } 46 \\
\text { Composite }\end{array}$} & WHOLE & 21.2 & 18.6 & $19.9^{Q C: 5,7}$ \\
\hline 180 & & WHOLE & 26.8 & 23.5 & $25.15^{\mathrm{QC}: 5,7}$ \\
\hline \multicolumn{2}{|c|}{ 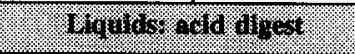 } & & 19./mi. & $4 \% \operatorname{lin}$ & . 18 tinl. \\
\hline 204 & $\begin{array}{l}\text { Core } 46 \\
\text { Composite }\end{array}$ & DL & 3.12 & --- & $3.12^{\mathrm{QC}: 7}$ \\
\hline \multicolumn{2}{|c|}{ 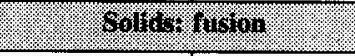 } & & 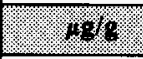 & $4 \% 8$ & $3.9 \%$ \\
\hline 175 & \multirow{2}{*}{\begin{tabular}{|l|} 
Core 45 \\
Composite
\end{tabular}} & WHOLE & 265 & 152 & $208.5^{\mathrm{QC}: 7.9}$ \\
\hline 176 & & WHOLE & 177 & 145 & $161^{\mathrm{eC}: 7}$ \\
\hline 179 & \multirow{2}{*}{\begin{tabular}{|l|} 
Core 46 \\
Composite
\end{tabular}} & WHOLE & 51.3 & 101 & $76.15^{\mathrm{CC}: 6,7,9}$ \\
\hline 180 & & WHOLE & 115 & 87.6 & $101.3^{\mathrm{QC}: 6,7,9}$ \\
\hline \multicolumn{2}{|c|}{ soldor water dy } & & $.90 \%$ & 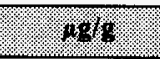 & 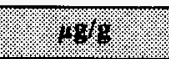 \\
\hline 175 & \multirow{2}{*}{$\begin{array}{l}\text { Core } 45 \\
\text { Composite }\end{array}$} & WHOLE & $<2.54$ & $<2.54$ & $<2.54^{\mathrm{Qc}: 7}$ \\
\hline 176 & & WHOLE & 9.8 & $<2.55$ & $<6.175^{\text {QC:7,9 }}$ \\
\hline 179 & \multirow{2}{*}{$\begin{array}{l}\text { Core } 46 \\
\text { Composite }\end{array}$} & WHOLE & $<2.54$ & $<2.54$ & $<2.54^{\mathrm{QC}: 7}$ \\
\hline 180 & & WHOLE & $<2.5$ & $<2.52$ & $<2.51^{\mathrm{QC}: 7}$ \\
\hline
\end{tabular}

Note:

${ }^{1}$ Homogenization test sample 
HNF-SD-WM-ER-372 Rev. 1

Table B2-38. Tank 241-T-104 Analytical Results: Zirconium (ICP).

\begin{tabular}{|c|c|c|c|c|c|}
\hline 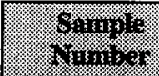 & $(4+3)$ & Somplo & 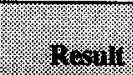 & 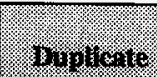 & 181.114 \\
\hline \multicolumn{2}{|c|}{ Winu } & 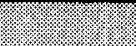 & $4 \%$ & 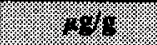 & $4 \%$ \\
\hline $147^{1}$ & \multirow[t]{2}{*}{ 46: 2} & WHOLE & 87.2 & 75.7 & $81.45^{\mathrm{QC}: 4,10}$ \\
\hline $146^{1}$ & & WHOLE & 52.9 & 59 & $55.95^{\mathrm{QC}: 4,10}$ \\
\hline 175 & \multirow{2}{*}{$\begin{array}{l}\text { Core } 45 \\
\text { Composite }\end{array}$} & WHOLE & 35.3 & 42 & $38.65^{\mathrm{QC}: 4,10}$ \\
\hline 176 & & WHOLE & 58.3 & 48.1 & $53.2^{\mathrm{QC}: 4,10}$ \\
\hline 179 & \multirow{2}{*}{\begin{tabular}{|l|} 
Core 46 \\
Composite
\end{tabular}} & WHOLE & 92.3 & 76.1 & $84.2^{\mathrm{QC}: 4,10}$ \\
\hline 180 & & WHOLE & 90.4 & 97.1 & $93.75^{\mathrm{QC:4,10}}$ \\
\hline \multicolumn{2}{|c|}{ 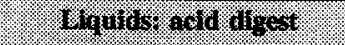 } & & \% Swa & 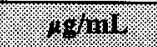 & $4 \% 1 m 1$ \\
\hline 204 & $\begin{array}{l}\text { Core } 46 \\
\text { Composite }\end{array}$ & $\mathrm{DL}$ & 3.42 & $-\cdots$ & $3.42^{\mathrm{QC}: 4}$ \\
\hline \multicolumn{2}{|c|}{$80106 \% 1010 \%$} & & 18148 & (6) & $.18 \%$ \\
\hline 175 & \multirow{2}{*}{$\begin{array}{l}\text { Core } 45 \\
\text { Composite }\end{array}$} & WHOLE & 33.7 & 27.7 & $30.7^{\mathrm{QC}: 4}$ \\
\hline 176 & & WHOLE & 31.7 & 52.8 & $42.25^{\mathrm{QC} 4}$ \\
\hline 179 & \multirow{2}{*}{$\begin{array}{l}\text { Core } 46 \\
\text { Composite }\end{array}$} & WHOLE & 34.8 & 44 & $39.4^{\mathrm{QC}: 4,9}$ \\
\hline 180 & & WHOLE & 33.6 & 41.4 & $37.5^{\mathrm{QC}: 4,9}$ \\
\hline \multicolumn{2}{|c|}{ 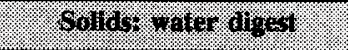 } & & 3819 & $18 \%$ & 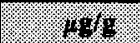 \\
\hline 175 & \multirow{2}{*}{$\begin{array}{l}\text { Core } 45 \\
\text { Composite }\end{array}$} & WHOLE & 2.23 & 2.59 & $2.41^{\mathrm{QC}: 4}$ \\
\hline 176 & & WHOLE & 2.69 & 2.7 & $2.695^{\mathrm{QC}: 4}$ \\
\hline 179 & \multirow{2}{*}{$\begin{array}{l}\text { Core } 46 \\
\text { Composite }\end{array}$} & WHOLE & 2.15 & 2.15 & $2.15^{\mathrm{QC}: 4,7}$ \\
\hline 180 & & WHOLE & 3.19 & 1.91 & $2.55^{\mathrm{QC}: 4}$ \\
\hline
\end{tabular}

Note:

${ }^{1}$ Homogenization test sample 
HNF-SD-WM-ER-372 Rev. 1

Table B2-39. Tank 241-T-104 Analytical Results: Chloride (IC).

\begin{tabular}{|c|c|c|c|c|c|}
\hline Sringle & Sirnple & $\begin{array}{l}\text { Sarople. } \\
\text { romima }\end{array}$ & Plesali: & 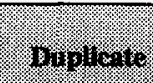 & 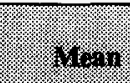 \\
\hline \multicolumn{2}{|c|}{ 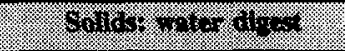 } & (3:-1: & $10 \% 10$ & 100 & 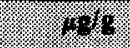 \\
\hline 175 & \multirow{2}{*}{\begin{tabular}{|l|} 
Core 45 \\
Composite
\end{tabular}} & WHOLE & 689 & 629 & $659^{Q C: 2}$ \\
\hline 176 & & WHOLE & 663 & 658 & $660.5^{\mathrm{Q} C 2}$ \\
\hline 179 & \multirow{2}{*}{$\begin{array}{l}\text { Core } 46 \\
\text { Composite }\end{array}$} & WHOLE: & 664 & 729 & $696.5^{\mathrm{QC}: 2}$ \\
\hline 180 & & WHOLE & 665 & 659 & $662^{Q C: 2}$ \\
\hline \multicolumn{2}{|c|}{ Yopins } & 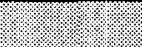 & 96 & 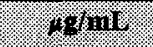 & Horitin \\
\hline 204 & $\begin{array}{l}\text { Core } 46 \\
\text { Composite }\end{array}$ & DL & 1,560 & 1,470 & $1,515^{\mathrm{QC}: 4}$ \\
\hline
\end{tabular}

Table B2-40. Tank 241-T-104 Analytical Results: Fluoride (IC).

\begin{tabular}{|c|c|c|c|c|c|}
\hline 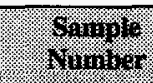 & $\begin{array}{l}\text { Sampite. } \\
\text { Yountion }\end{array}$ & $\begin{array}{l}\text { Simplio } \\
\text { Rortion }\end{array}$ & It: Rerait & bupilicate & Neir. \\
\hline \multicolumn{2}{|c|}{ 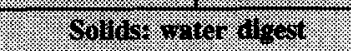 } & 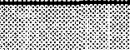 & 486 & 1.18 & 10 \\
\hline 175 & \multirow{2}{*}{$\begin{array}{l}\text { Core } 45 \\
\text { Composite }\end{array}$} & WHOLE & 8,950 & 8,720 & $8,835^{\mathrm{QC}: 2}$ \\
\hline 176 & & WHOLE & 8,290 & 8,480 & $8,385^{Q C: 2}$ \\
\hline 179 & \multirow{2}{*}{$\begin{array}{l}\text { Core } 46 \\
\text { Composite }\end{array}$} & WHOLE & 8,730 & 8,980 & $8,855^{\mathrm{QC}: 2}$ \\
\hline 180 & & WHOLE & 8,360 & 8,040 & $8,200^{\mathrm{QC}: 2}$ \\
\hline (1): & Triguns: & (3) & 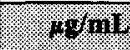 & istinit & 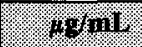 \\
\hline 204 & $\begin{array}{l}\text { Core } 46 \\
\text { Composite }\end{array}$ & $\mathrm{DL}$ & 4,340 & 4,050 & $4,195^{\mathrm{QC}: 4,10}$ \\
\hline
\end{tabular}


Table B2-41. Tank 241-T-104 Analytical Results: Nitrate (IC).

\begin{tabular}{|c|c|c|c|c|c|}
\hline 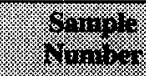 & 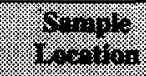 & 梦, & $4+2=311$ & $4 \cdot 19 \cdot 10$ & $14 \%$ \\
\hline \multicolumn{2}{|c|}{ 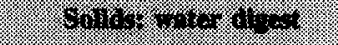 } & & $4 \%$ & 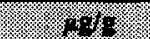 & $4 \%$ \\
\hline 175 & \multirow{2}{*}{$\begin{array}{l}\text { Core } 45 \\
\text { Composite }\end{array}$} & WHOLE & 56,200 & 56,200 & $56,200^{\mathrm{QC}: 2}$ \\
\hline 176 & & WHOLE & 57,900 & 59,000 & $58,450^{\mathrm{Qc}: 2}$ \\
\hline 179 & \multirow{2}{*}{$\begin{array}{l}\text { Core } 46 \\
\text { Composite }\end{array}$} & WHOLE & 59,800 & 59,800 & $59,800^{Q c: 2}$ \\
\hline 180 & & WHOLE & 59,100 & 56,200 & $57,650^{\mathrm{Qc:2}}$ \\
\hline \multicolumn{2}{|c|}{ Solntion } & & \% & 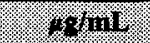 & 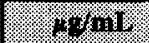 \\
\hline 204 & $\begin{array}{l}\text { Core } 46 \\
\text { Composite }\end{array}$ & $\mathrm{DL}$ & 97,900 & 97,400 & $97,650^{\mathrm{CC}: 2,4}$ \\
\hline
\end{tabular}

Table B2-42. Tank 241-T-104 Analytical Results: Nitrite (IC).

\begin{tabular}{|c|c|c|c|c|c|}
\hline $\begin{array}{l}\text { oping } \\
\text { (n) }\end{array}$ & 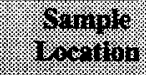 & कonum & resintit. & 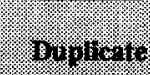 & Helin \\
\hline \multicolumn{2}{|c|}{ (6) } & & 40 & $4+4$ & 46 \\
\hline 175 & \multirow{2}{*}{$\begin{array}{l}\text { Core } 45 \\
\text { Composite }\end{array}$} & WHOLE & 4,070 & 3,990 & $4,030^{\mathrm{QC}: 2}$ \\
\hline 176 & & WHOLE & 4,120 & 4,140 & $4,130^{\mathrm{QC}: 2}$ \\
\hline 179 & \multirow{2}{*}{$\begin{array}{l}\text { Core } 46 \\
\text { Composite }\end{array}$} & WHOLE & 3,970 & 4,120 & $4,045^{\mathrm{oc}: 2}$ \\
\hline 180 & & WHOLE & 4,110 & 4,130 & $4,120^{\mathrm{QC}: 2}$ \\
\hline \multicolumn{2}{|c|}{ 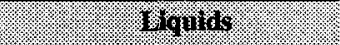 } & & 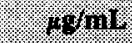 & 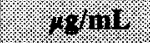 & foptine \\
\hline 204 & $\begin{array}{l}\text { Core } 46 \\
\text { Composite }\end{array}$ & $\mathrm{DL}$ & 6,140 & 6,030 & $6,085^{Q C: 2,4}$ \\
\hline
\end{tabular}


Table B2-43. Tank 241-T-104 Analytical Results: Phosphate (IC).

\begin{tabular}{|c|c|c|c|c|c|}
\hline Sample & Somple & Sample & Rernill & Hourate & Mran \\
\hline \multicolumn{2}{|c|}{ Sollas r yater digest } & & 1018 & 40 & 100 \\
\hline 175 & \multirow{2}{*}{$\begin{array}{l}\text { Core } 45 \\
\text { Composite }\end{array}$} & WHOLE & 16,800 & 16,400 & $16,600^{\mathrm{QC}: 2}$ \\
\hline 176 & & WHOLE & 17,100 & 17,500 & $17,300^{\mathrm{QC}: 2}$ \\
\hline 179 & \multirow{2}{*}{$\begin{array}{l}\text { Core } 46 \\
\text { Composite }\end{array}$} & WHOLE & 18,300 & 19,100 & $18,700^{\mathrm{QC}: 2}$ \\
\hline 180 & & WHOLE & 18,500 & 18,800 & $18,650^{\mathrm{Qc:2}}$ \\
\hline \multicolumn{2}{|c|}{ Wiquícs } & & $48 \mathrm{mI}$ & $4 \mathrm{gmi}$ & HonI \\
\hline 204 & $\begin{array}{l}\text { Core } 46 \\
\text { Composite }\end{array}$ & DL & 25,000 & 25,000 & $25,000^{\mathrm{QC}: 4,10}$ \\
\hline
\end{tabular}

Table B2-44. Tank 241-T-104 Analytical Results: Sulfate (IC).

\begin{tabular}{|c|c|c|c|c|c|}
\hline Wample & Gample: & Sample & Resiall & Buplicate & Mean \\
\hline \multicolumn{2}{|c|}{ Sollis: water algest } & (:) & 1098 & 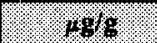 & 4848 \\
\hline 175 & \multirow{2}{*}{$\begin{array}{l}\text { Core } 45 \\
\text { Composite }\end{array}$} & WHOLE & 3,930 & 3,830 & $3,880^{\mathrm{Qc:2}}$ \\
\hline 176 & & WHOLE & 3,870 & 3,970 & $3,920^{\mathrm{QC}: 2}$ \\
\hline 179 & \multirow{2}{*}{$\begin{array}{l}\text { Core } 46 \\
\text { Composite }\end{array}$} & WHOLE & 3,780 & 4,060 & $3,920^{\mathrm{QC}: 2}$ \\
\hline 180 & & WHOLE & 3,850 & 3,880 & $3,865^{\mathrm{QC}: 2}$ \\
\hline \multicolumn{2}{|c|}{ Wiquids } & & rofril. & 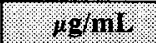 & motmal \\
\hline 204 & $\begin{array}{l}\text { Core } 46 \\
\text { Composite }\end{array}$ & $\mathrm{DL}$ & 4,190 & 4,330 & $4,260^{Q C: 4}$ \\
\hline
\end{tabular}


Table B2-45. Tank 241-T-104 Analytical Results: Total Uranium (LF).

\begin{tabular}{|c|c|c|c|c|c|}
\hline 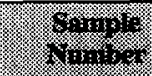 & $\left(\frac{1}{4}\right)$ & 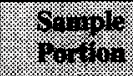 & $8 x=110$ & $2813)$ & Hin \\
\hline \multicolumn{2}{|c|}{ 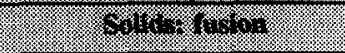 } & (2). & \% & \% & 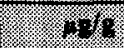 \\
\hline 175 & \multirow{2}{*}{$\begin{array}{l}\text { Core } 45 \\
\text { Composite }\end{array}$} & WHOLE & 896 & 864 & 880 \\
\hline 176 & & WHOLE & 965 & 836 & 900.5 \\
\hline 179 & \multirow{2}{*}{$\begin{array}{l}\text { Core } 46 \\
\text { Composite }\end{array}$} & WHOLE & 834 & 899 & 866.5 \\
\hline 180 & & WHOLE & 894 & 990 & 942 \\
\hline
\end{tabular}

Table B2-46. Tank 241-T-104 Analytical Results: Arsenic (AA [As]).

\begin{tabular}{|c|c|c|c|c|c|}
\hline 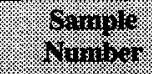 & 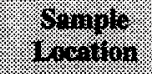 & 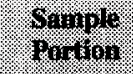 & $36+311$ & OH3) & $1 \%$ \\
\hline \multicolumn{2}{|c|}{ 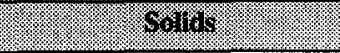 } & & $1 \%$ & $4 \%$ & in. \\
\hline 175 & \multirow{2}{*}{$\begin{array}{l}\text { Core } 45 \\
\text { Composite }\end{array}$} & WHOLE & 0.787 & 0.912 & $0.8495^{\mathrm{QC}: 3,9}$ \\
\hline 176 & & WHOLE & 0.751 & 0.662 & $0.7065^{\mathrm{QC}: 3,8}$ \\
\hline 179 & \multirow{2}{*}{$\begin{array}{l}\text { Core } 46 \\
\text { Composite }\end{array}$} & WHOLE & 0.714 & 0.706 & $0.71^{\mathrm{QC}: 4,8}$ \\
\hline 180 & & WHOLE & 0.668 & 0.589 & $0.6285^{\mathrm{QC}: 4,8}$ \\
\hline \multicolumn{2}{|c|}{ 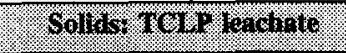 } & & 4.110 & $49 / 101 \%$ & 6rin \\
\hline 196 & \multirow{2}{*}{$\begin{array}{l}\text { Core } 45 \\
\text { Composite }\end{array}$} & WHOLE & 0.015 & 0.016 & $0.0155^{\mathrm{QC}: 4,8,10}$ \\
\hline 198 & & WHOLE & $<0.0125$ & 0.417 & $<0.21475$ \\
\hline
\end{tabular}


HNF-SD-WM-ER-372 Rev. 1

Table B2-47. Tank 241-T-104 Analytical Results: Selenium (AA [Se]).

\begin{tabular}{|c|c|c|c|c|c|}
\hline 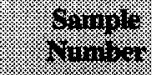 & 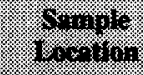 & 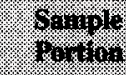 & gesilu & 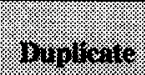 & (1). \\
\hline \multicolumn{2}{|c|}{$3 \%$} & & 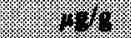 & s.sy & (.). \\
\hline 175 & \multirow{2}{*}{$\begin{array}{l}\text { Core } 45 \\
\text { Composite }\end{array}$} & WHOLE & $<0.5$ & $<0.5$ & $<0.5^{\mathrm{Q}: 10}$ \\
\hline 176 & & WHOLE & $<0.5$ & $<0.5$ & $<0.5^{\mathrm{QC}: 10}$ \\
\hline 179 & \multirow{2}{*}{$\begin{array}{l}\text { Core } 46 \\
\text { Composite }\end{array}$} & WHOLE & $<0.5$ & $<0.5$ & $<0.5^{\mathrm{QC}: 4,8,10}$ \\
\hline 180 & & WHOLE & $<0.5$ & $<0.25$ & $<0.375^{\mathrm{QC}: 4,8,10}$ \\
\hline \multicolumn{2}{|c|}{ 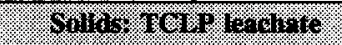 } & & rom & $101811 \%$ & $89611 \%$ \\
\hline 196 & $\begin{array}{l}\text { Core } 45 \\
\text { Composite }\end{array}$ & WHOLE & 0.021 & 0.019 & $0.02^{\mathrm{QC}: 8}$ \\
\hline
\end{tabular}

Table B2-48. Tank 241-T-104 Analytical Results: Mercury (CVAA [Hg]).

\begin{tabular}{|c|c|c|c|c|c|}
\hline 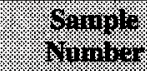 & 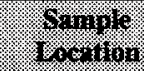 & (5) & $\mathrm{R}=\mathrm{s}, \mathrm{m}$ & 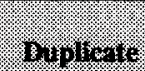 & He \\
\hline \multicolumn{2}{|c|}{ 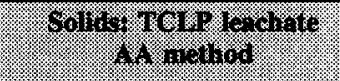 } & & 6,191 & $\%$ & (4) \\
\hline 196 & $\begin{array}{l}\text { Core } 45 \\
\text { Composite }\end{array}$ & WHOLE & $<0.0025$ & $<0.0025$ & $<0.0025^{\mathrm{QC:2,B}}$ \\
\hline \multicolumn{2}{|c|}{ 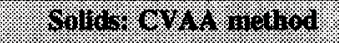 } & & 10 & 4.98 & 90 \\
\hline 175 & \multirow{2}{*}{$\begin{array}{l}\text { Core } 45 \\
\text { Composite }\end{array}$} & WHOLE & $<0.125$ & 0.127 & $<0.126^{\mathrm{QC}: 2}$ \\
\hline 176 & & WHOLE & $<0.125$ & $<0.125$ & $<0.125^{Q C: 2}$ \\
\hline 179 & \multirow{2}{*}{$\begin{array}{l}\text { Core } 46 \\
\text { Composite }\end{array}$} & WHOLE & $<0.125$ & $<0.125$ & $<0.125^{Q C: 2,4}$ \\
\hline 180 & & WHOLE & $<0.125$ & $<0.125$ & $<0.125^{\mathrm{QC}: 2,8}$ \\
\hline
\end{tabular}


Table B2-49. Tank 241-T-104 Analytical Results: Ammonia (Distillation).

\begin{tabular}{|l|l|l|l|l|l|}
\hline \\
\hline
\end{tabular}

Table B2-50. Tank 241-T-104 Analytical Results: Cyanide (Spec [CN]).

\begin{tabular}{|c|c|c|c|c|c|}
\hline 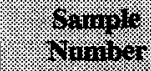 & 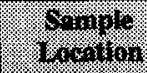 & 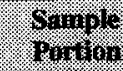 & 14.2111 & $134,1)$, 19 & 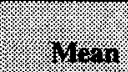 \\
\hline \multicolumn{2}{|c|}{ Whing } & & $10 \%$ & 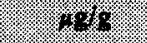 & 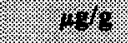 \\
\hline 175 & \multirow{2}{*}{$\begin{array}{l}\text { Core } 45 \\
\text { Composite }\end{array}$} & WHOLE & $<2$ & $<2$ & $<2^{\mathrm{QC}: 2}$ \\
\hline 176 & & WHOLE & $<2$ & $<2$ & $<2^{\mathrm{QC}: 2}$ \\
\hline \multicolumn{2}{|c|}{$061 \%$} & & 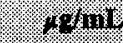 & H\%1nit & $4 \%$ \\
\hline 179 & \multirow{2}{*}{$\begin{array}{l}\text { Core } 46 \\
\text { Composite }\end{array}$} & WHOLE & $<2$ & $<2$ & $<2^{Q C: 2}$ \\
\hline 180 & & WHOLE & $<2$ & $<2$ & $<2^{\mathrm{QC}: 2}$ \\
\hline \multicolumn{2}{|c|}{ 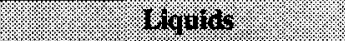 } & & 42101 & $64 \%$ & \% $1111 \%$ \\
\hline 204 & $\begin{array}{l}\text { Core } 46 \\
\text { Composite }\end{array}$ & DL & 0.692 & 0.715 & 0.7035 \\
\hline
\end{tabular}


Table B2-51. Tank 241-T-104 Analytical Results: Nitrite (Spectrophotometric).

\begin{tabular}{|c|c|c|c|c|c|}
\hline . & 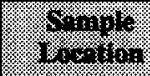 & 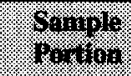 & 10 & Whosic & 12. \\
\hline \multicolumn{2}{|c|}{ 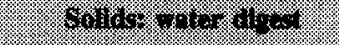 } & & 8.94 & 4.94 & 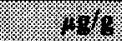 \\
\hline 175 & \multirow{2}{*}{$\begin{array}{l}\text { Core } 45 \\
\text { Composite }\end{array}$} & WHOLE & 4,210 & 4,100 & $4,155^{Q C: 2}$ \\
\hline 176 & & WHOLE & 4,340 & 4,340 & $4,340^{\mathrm{QC}: 2}$ \\
\hline 179 & \multirow{2}{*}{$\begin{array}{l}\text { Core } 46 \\
\text { Composite }\end{array}$} & WHOLE & 4,110 & 4,470 & $4,290^{\mathrm{Qc}: 2}$ \\
\hline 180 & & WHOLE & 4,160 & 4,170 & $4,165^{\mathrm{QC}: 2}$ \\
\hline
\end{tabular}

Table B2-52. Tank 241-T-104 Analytical Results: pH Measurement (pH).

\begin{tabular}{|c|c|c|c|c|c|}
\hline 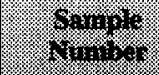 & (x) & 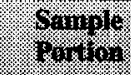 & (3) & (5) & Y) \\
\hline \multicolumn{2}{|c|}{ 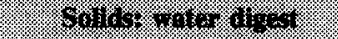 } & & ail $\%$ & 1inis 85 & 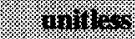 \\
\hline 175 & \multirow{2}{*}{$\begin{array}{l}\text { Core } 45 \\
\text { Composite }\end{array}$} & WHOLE & 10 & 10 & $10^{\mathrm{QC}: 2}$ \\
\hline 176 & & WHOLE & 10.02 & 9.98 & $10^{\mathrm{QC}: 2}$ \\
\hline 179 & \multirow{2}{*}{$\begin{array}{l}\text { Core } 46 \\
\text { Composite }\end{array}$} & WHOLE & 10.02 & 10.02 & $10.02^{Q C: 2}$ \\
\hline 180 & & WHOLE & 10.05 & 9.92 & $9.985^{\mathrm{QC}: 2}$ \\
\hline \multicolumn{2}{|c|}{ Thy } & & $11118 \%$ & $10111 \%$ & 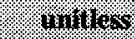 \\
\hline 204 & $\begin{array}{l}\text { Core } 46 \\
\text { Composite }\end{array}$ & $\mathrm{DL}$ & 9.94 & 9.96 & $9.95^{\mathrm{QC}: 4}$ \\
\hline
\end{tabular}


Table B2-53. Tank 241-T-104 Analytical Results: Bis(2-ethylhexyl) phthalate (SVOA).

\begin{tabular}{|c|c|c|c|c|c|}
\hline (4) & 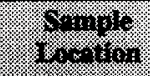 & 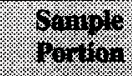 & $9+2=11$ & 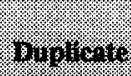 & 1... \\
\hline \multicolumn{2}{|c|}{2} & & $y_{1}$ & \% & $\%$ \\
\hline 93-01809-E1 & \multirow{2}{*}{$\begin{array}{l}\text { Core } 45 \\
\text { Composite }\end{array}$} & WHOLE & 1.2 & -- & $1.2^{\mathrm{QC}: 1}$ \\
\hline 93-01810-E1 & & WHOLE & 0.95 & --- & $0.95^{Q C: 1}$ \\
\hline 93-01811-E1 & \multirow{2}{*}{$\begin{array}{l}\text { Core } 46 \\
\text { Composite }\end{array}$} & WHOLE & $<9.2$ & -- & $<9.2^{\mathrm{QC}: 1}$ \\
\hline 93-01812-E1 & & WHOLE & $<11$ & --- & $<11^{\mathrm{QC}: 1}$ \\
\hline
\end{tabular}

Table B2-54. Tank 241-T-104 Analytical Results: Dodecane (SVOA).

\begin{tabular}{|c|c|c|c|c|c|}
\hline 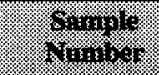 & $\left(\frac{1}{8+\infty}\right)$ & 4anos & $19+11$ & Hounsone & 19.4\% \\
\hline \multicolumn{2}{|c|}{60} & & 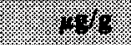 & \% & rys. \\
\hline 93-01809-E1 & \multirow{2}{*}{$\begin{array}{l}\text { Core } 45 \\
\text { Composite }\end{array}$} & WHOLE & 190 & -- & $190^{\mathrm{QC}: 1}$ \\
\hline 93-01810-E1 & & WHOLE & 170 & --- & $170^{\mathrm{QC}: 1}$ \\
\hline 93-01811-E1 & \multirow{2}{*}{$\begin{array}{l}\text { Core } 46 \\
\text { Composite }\end{array}$} & WHOLE & 67 & -- & $67^{\mathrm{QC}: 1}$ \\
\hline 93-01812-E1 & & WHOLE & 120 & -- & $120^{Q C: 1}$ \\
\hline
\end{tabular}

Table B2-55. Tank 241-T-104 Analytical Results: Pentadecane (SVOA).

\begin{tabular}{|c|c|c|c|c|c|}
\hline 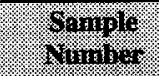 & 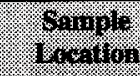 & 6ongen & 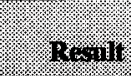 & 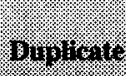 & $4 \%$ \\
\hline \multicolumn{2}{|c|}{ (6) } & & $4 \%$ & $8 \%$ & 104 \\
\hline 93-01809-E1 & \multirow{2}{*}{$\begin{array}{l}\text { Core } 45 \\
\text { Composite }\end{array}$} & WHOLE & 27 & --- & $27^{\mathrm{QC}: 1}$ \\
\hline 93-01810-E1 & & WHOLE & 25 & -- & $25^{\mathrm{QC}: 1}$ \\
\hline $93-01811-\mathrm{E} 1$ & \multirow{2}{*}{$\begin{array}{l}\text { Core } 46 \\
\text { Composite }\end{array}$} & WHOLE & 13 & $\cdots$ & $13^{\mathrm{QC}: 1}$ \\
\hline 93-01812-E1 & & WHOLE & 18 & -- & $18^{\mathrm{QC}: 1}$ \\
\hline
\end{tabular}


Table B2-56. Tank 241-T-104 Analytical Results: Tetradecane (SVOA).

\begin{tabular}{|c|c|c|c|c|c|}
\hline 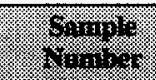 & 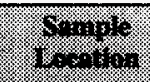 & 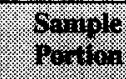 & $0,=111$ & (3) & 16 \\
\hline \multicolumn{2}{|c|}{40} & & 4 & $\% \%$ & 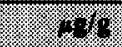 \\
\hline 93-01809-E1 & \multirow{2}{*}{$\begin{array}{l}\text { Core } 45 \\
\text { Composite }\end{array}$} & WHOLE & 600 & --- & $600^{\mathrm{QC}: 1}$ \\
\hline 93-01810-E1 & & WHOLE & 540 & --- & $540^{\mathrm{QC}: 1}$ \\
\hline 93-01811-E1 & \multirow{2}{*}{$\begin{array}{l}\text { Core } 46 \\
\text { Composite }\end{array}$} & WHOLE & 330 & --- & $330^{\mathrm{QC:1}}$ \\
\hline 93-01812-E1 & & WHOLE & 440 & --- & $440^{\text {QC:1 }}$ \\
\hline
\end{tabular}

Table B2-57. Tank 241-T-104 Analytical Results: Tridecane (SVOA).

\begin{tabular}{|c|c|c|c|c|c|}
\hline $\begin{array}{l}8 \\
6 \\
6\end{array}$ & (2) & 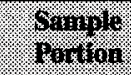 & if & Hepose & 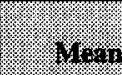 \\
\hline \multicolumn{2}{|c|}{ Hos } & & 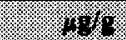 & 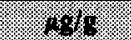 & 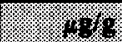 \\
\hline 93-01809-E1 & \multirow{2}{*}{$\begin{array}{l}\text { Core } 45 \\
\text { Composite }\end{array}$} & WHOLE & 700 & $-\cdots$ & $700^{\mathrm{QC}: 1}$ \\
\hline $93-01810-\mathrm{E} 1$ & & WHOLE & 630 & -- & $630^{\mathrm{oc}: 1}$ \\
\hline 93-01811-E1 & \multirow{2}{*}{$\begin{array}{l}\text { Core } 46 \\
\text { Composite }\end{array}$} & WHOLE & 340 & $\ldots$ & $340^{\mathrm{QC:1}}$ \\
\hline 93-01812-E1 & & WHOLE & 490 & -- & $490^{\text {oc:1 }}$ \\
\hline
\end{tabular}


Table B2-58. Tank 241-T-104 Analytical Results: Non-Detected SVOA Analytes. (2 sheets)

\begin{tabular}{|c|c|c|c|}
\hline 4in & $3 e_{1}+w_{1}$ & 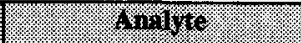 & 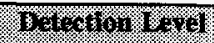 \\
\hline 1,2,4-Trichlorobenzene & $<11^{\mathrm{QC}: 1}$ & Benzo(a)pyrene & $<11^{\mathrm{QC}: 1}$ \\
\hline 1,2-Dichlorobenzene & $<11^{\mathrm{QC}: 1}$ & Benzo(b)fluoranthene & $<11^{\mathrm{QC}: 1}$ \\
\hline 1,3-Dichlorobenzene & $<11^{\mathrm{QC}: 1}$ & Benzo(ghi)perylene & $<11^{\mathrm{QC}: 1}$ \\
\hline 1,4-Dichlorobenzene & $<11^{Q C: 1}$ & Benzo(k)fluoranthene & $<11^{\mathrm{QC}: 1}$ \\
\hline 2,4,5-Trichlorophenol & $<53^{\mathrm{QC} 1}$ & Benzoic acid & $<53^{\mathrm{QC}: 1}$ \\
\hline 2,4,6-Trichlorophenol & $<11^{\mathrm{QC}: 1}$ & Benzyl alcohol & $<11^{\mathrm{QC}: 1}$ \\
\hline 2,4-Dichlorophenol & $<11^{\mathrm{QC}: 1}$ & $\begin{array}{l}\text { Bis(2-chloroethoxy)meth } \\
\text { ane }\end{array}$ & $<11^{\mathrm{QC}: 1}$ \\
\hline 2,4-Dimethylphenol & $<11^{\mathrm{QC}: 1}$ & $\begin{array}{l}\text { Bis(2-chloroisopropyl) } \\
\text { ether }\end{array}$ & $<11^{\mathrm{QC}: 1}$ \\
\hline 2,4-Dinitrophenol & $<53^{Q \mathrm{QC}: 1}$ & Bis(2-chloroethyl) ether & $<11^{\mathrm{QC}: 1}$ \\
\hline 2,4-Dinitrotoluene & $<11^{\mathrm{QC}: 1}$ & Butylbenzylphthalate & $<11^{\mathrm{QC}: 1}$ \\
\hline 2,6-Dinitrotoluene & $<11^{\mathrm{QC}: 1}$ & Chrysene & $<11^{\mathrm{QC}: 1}$ \\
\hline 2-Chloronaphthalene & $<11^{\mathrm{QC}: 1}$ & Di-n-butylphthalate & $<11^{\mathrm{QC}: 1}$ \\
\hline 2-Chlorophenol & $<11^{\mathrm{QC}: 1}$ & Di-n-octylphthalate & $<11^{\mathrm{QC:1}}$ \\
\hline 2-Methylnaphthalene & $<11^{\mathrm{QC}: 1}$ & Dibenz[a,h]anthracene & $<11^{\mathrm{QC}: 1}$ \\
\hline 2-Methylphenol & $<11^{Q C: 1}$ & Dibenzofuran & $<11^{\mathrm{QC:1}}$ \\
\hline 2-Nitroaniline & $<53^{\mathrm{QC}: 1}$ & Diethylphthalate & $<11^{\mathrm{QC}: 1}$ \\
\hline 2-Nitrophenol & $<11^{\mathrm{QC}: 1}$ & Dimethylphthalate & $<11^{\mathrm{QC:} 1}$ \\
\hline 3,3-Dichlorobenzidine & $<21^{Q \mathrm{QC}: 1}$ & \begin{tabular}{|l|} 
Fluoranthene \\
\end{tabular} & $<11^{\mathrm{QC}: 1}$ \\
\hline 3-Nitroaniline & $<53^{\mathrm{QC}: 1}$ & Fluorene & $<11^{\mathrm{QC:1}}$ \\
\hline 4,6-Dinitro-o-cresol & $<53^{Q C+1}$ & Hexachlorobenzene & $<11^{\mathrm{QC}: 1}$ \\
\hline $\begin{array}{l}\text { 4-Bromophenylphenyl } \\
\text { ether }\end{array}$ & $<11^{\mathrm{QC:1}}$ & Hexachlorobutadiene & $<11^{\mathrm{QC}: 1}$ \\
\hline 4-Chloro-3-methylphenol & $<11^{Q C: 1}$ & $\begin{array}{l}\text { Hexachlorocyclopenta- } \\
\text { diene }\end{array}$ & $<11^{\mathrm{QC}: 1}$ \\
\hline 4-Chloroaniline & $<11^{\mathrm{QC:I}}$ & Hexachloroethane & $<11^{\mathrm{QC}: 1}$ \\
\hline $\begin{array}{l}\text { 4-Chlorophenylphenyl } \\
\text { ether }\end{array}$ & $<11^{\mathrm{QC}: 1}$ & Indeno(1,2,3-cd)pyrene & $<11^{\mathrm{QC}: 1}$ \\
\hline 4-Methylphenol & $<11^{\mathrm{QC}: 1}$ & Isophorone & $<11^{\mathrm{QC}: 1}$ \\
\hline
\end{tabular}


Table B2-58. Tank 241-T-104 Analytical Results: Non-Detected SVOA Analytes. (2 sheets)

\begin{tabular}{|c|c|c|c|}
\hline (1.) & 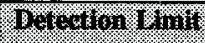 & Hing & 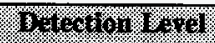 \\
\hline 4-Nitroaniline & $<53^{Q C: 1}$ & $\begin{array}{l}\text { N-nitroso-di-n-dipropyla } \\
\text { mine }\end{array}$ & $<11^{\mathrm{QC}: 1}$ \\
\hline 4-Nitrophenol & $<53^{\mathrm{QC}: 1}$ & N-nitrosodiphenylamine & $<11^{\mathrm{QC}: 1}$ \\
\hline Acenaphthene & $<11^{\mathrm{QC}: 1}$ & Naphthalene & $<11^{\mathrm{QC}: 1}$ \\
\hline Acenaphthylene & $<11^{\mathrm{QC}: 1}$ & Nitrobenzene & $<11^{\mathrm{QC}: 1}$ \\
\hline Anthracene & $<11^{\mathrm{QC}: 1}$ & Pentachlorophenol & $<53^{\mathrm{QC:1}}$ \\
\hline Phenol & $<11^{\text {QC:1 }}$ & Pyrene & $<11^{\mathrm{QC}: 1}$ \\
\hline Benzo(a)anthracene & $<11^{\mathrm{QC:1}}$ & Phenanthrene & $<11^{\mathrm{QC}: 1}$ \\
\hline
\end{tabular}

Table B2-59. Tank 241-T-104 Analytical Results: Acetone (VOA)

\begin{tabular}{|c|c|c|c|c|c|}
\hline . & . & . 60 & $12=11$ & 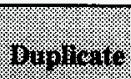 & 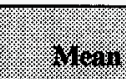 \\
\hline \multicolumn{2}{|c|}{ 3\%o } & & 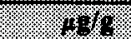 & 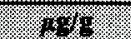 & 40 \\
\hline COR45K108 & 45: 1 & WHOLE & $<4.4$ & -- & $<4.4^{\mathrm{QC}: 1}$ \\
\hline COR45K 110 & $45: 3$ & WHOLE & $<5.4$ & -+- & $<5.4^{\mathrm{QC}: 1}$ \\
\hline COR45K112 & $45: 5$ & WHOLE & $<5.8$ & $-\cdots$ & $<5.8^{\mathrm{QC}: 1}$ \\
\hline COR45K 114 & $45: 7$ & WHOLE & 0.81 & -- & $0.81^{\mathrm{QC}: 1}$ \\
\hline COR45K 116 & $45: 9$ & WHOLE & $<4.6$ & -- & $<4.6^{\mathrm{QC:1}}$ \\
\hline COR46S2 & $46: 2$ & WHOLE & $<6.5$ & $\begin{array}{ll}-- \\
\end{array}$ & $<6.5^{\mathrm{QC}: 1}$ \\
\hline COR46K120 & $46: 3$ & WHOLE & 2.1 & $\cdots$ & $2.1^{\mathrm{QC}: \mathrm{I}}$ \\
\hline COR46S4 & $46: 4$ & WHOLE & $<6$ & --- & $<6^{\mathrm{QC}: 1}$ \\
\hline COR46K121 & $46: 5$ & WHOLE & $<5.2$ & $-\cdots$ & $<5.2^{\mathrm{QC}: 1}$ \\
\hline COR46K 122 & $46: 6$ & WHOLE & 3.7 & $\overline{---}$ & $3.7^{\mathrm{QCi1}}$ \\
\hline COR46K 123 & $46: 7$ & WHOLE & $<4.6$ & $-\cdots$ & $<4.6^{\mathrm{QC}: 1}$ \\
\hline COR46S8 & $46: 8$ & WHOLE & $<4.9$ & $\cdots$ & $<4.9^{\mathrm{QC}: 1}$ \\
\hline COR46S9 & $46: 9$ & WHOLE & $<6.8$ & -+- & $<6.8^{\mathrm{QC}: 1}$ \\
\hline
\end{tabular}


HNF-SD-WM-ER-372 Rev. 1

Table B2-60. Tank 241-T-104 Analytical Results: Hexamethyl Disiloxane (VOA).

\begin{tabular}{|c|c|c|c|c|c|}
\hline 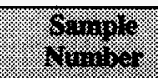 & $\frac{1}{4+3515}$ & 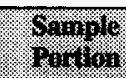 & 18,411 & 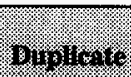 & 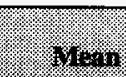 \\
\hline \multicolumn{3}{|c|}{ Y) } & 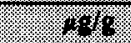 & $4 \%$ & 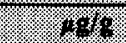 \\
\hline COR45K 108 & 45: 1 & WHOLE & 3.1 & -- & $3.1^{\mathrm{QC}: 1}$ \\
\hline COR45K 110 & $45: 3$ & WHOLE & 4.5 & $\overline{---}$ & $4.5^{\mathrm{QC}: 1}$ \\
\hline COR45K112 & $45: 5$ & WHOLE & 2.4 & -- & $2.4^{Q C: 1}$ \\
\hline COR45K114 & $45: 7$ & WHOLE & 3.5 & -- & $3.5^{\mathrm{QC}: 1}$ \\
\hline COR45K116 & $45: 9$ & WHOLE & 4.4 & $-\cdots$ & $4.4^{\mathrm{QC}: 1}$ \\
\hline COR46K120 & $46: 3$ & WHOLE & 2.6 & --- & $2.6^{\mathrm{QC:}: 1}$ \\
\hline COR46K121 & $46: 5$ & WHOLE & 3.3 & -- & $3.3^{\mathrm{QC}: 1}$ \\
\hline COR46K122 & $46: 6$ & WHOLE & 5.2 & -- & $5.2^{\mathrm{QC}: 1}$ \\
\hline COR46K123 & $46: 7$ & WHOLE & 1.6 & -+- & $1.6^{\mathrm{QC}: 1}$ \\
\hline COR46S9 & $46: 9$ & WHOLE & 8.1 & -- & $8.1^{\mathrm{QC}: 1}$ \\
\hline
\end{tabular}

Table B2-61. Tank 241-T-104 Analytical Results: Methoxytrimethyl Silane (VOA).

\begin{tabular}{|c|c|c|c|c|c|}
\hline ( & 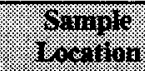 & 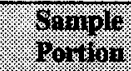 & . I 18.41 & 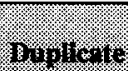 & (1) \\
\hline \multicolumn{2}{|c|}{$3 \% 18$} & & 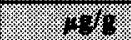 & 10 & 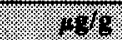 \\
\hline COR45K108 & 45: 1 & WHOLE & 3.8 & --- & $3.8^{\mathrm{QC}: 1}$ \\
\hline COR45K110 & $45: 3$ & WHOLE & 9.5 & $-\cdots$ & $9.5^{\mathrm{CC}: 1}$ \\
\hline COR45K112 & $45: 5$ & WHOLE & 7.6 & $\ldots$ & $7.6^{\mathrm{QC:} 1}$ \\
\hline COR45K114 & $45: 7$ & WHOLE & 12 & -- & $12^{\mathrm{QC:1}}$ \\
\hline COR45K116 & $45: 9$ & WHOLE & 18 & -- & $18^{\mathrm{QC}: 1}$ \\
\hline COR46S2 & $46: 2$ & WHOLE & 11 & -- & $11^{\mathrm{QC}: 1}$ \\
\hline COR46K120 & $46: 3$ & WHOLE & 5.7 & --- & $5.7^{\mathrm{QC:1}}$ \\
\hline COR46S4 & $46: 4$ & WHOLE & 17 & --- & $17^{\mathrm{QC}: 1}$ \\
\hline COR46K121 & $46: 5$ & WHOLE & 6.1 & --- & $6.1^{\mathrm{QC}: 1}$ \\
\hline COR46K 122 & $46: 6$ & WHOLE & 4 & --- & $4^{\mathrm{QC:1}}$ \\
\hline COR46K123 & $46: 7$ & WHOLE & 3 & -+- & $3^{\mathrm{QC}: 1}$ \\
\hline COR46S8 & $46: 8$ & WHOLE & 13 & --- & $13^{\mathrm{QC}: 1}$ \\
\hline COR46S9 & $46: 9$ & WHOLE & 21 & $-\cdots$ & $21^{\mathrm{QC}: 1}$ \\
\hline
\end{tabular}


Table B2-62. Tank 241-T-104 Analytical Results: Methylenechloride (VOA).

\begin{tabular}{|c|c|c|c|c|c|}
\hline 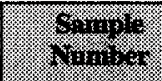 & Opon, & Soriole & I tesinit & oupiarate & nf.r. \\
\hline \multicolumn{2}{|c|}{ Sogum } & I: & 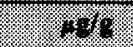 & 114 & $19 \% \mathrm{~s}$ \\
\hline COR45K108 & 45: 1 & WHOLE & $<2.2$ & --- & $<2.2^{\mathrm{QC}: 1}$ \\
\hline COR45K110 & $45: 3$ & WHOLE & $<2.7$ & -- & $<2.7^{\mathrm{QC}: 1}$ \\
\hline COR45K112 & $45: 5$ & WHOLE & $<2.9$ & --- & $<2.9^{\mathrm{QC}: 1}$ \\
\hline COR45K114 & $45: 7$ & WHOLE & $<3$ & $\ldots$ & $<3^{\mathrm{QC}: 1}$ \\
\hline COR45K116 & $45: 9$ & WHOLE & $<2.3$ & -- & $<2.3^{\mathrm{QC}: 1}$ \\
\hline COR46S2 & 46: 2 & WHOLE & $<3.3$ & --- & $<3.3^{\mathrm{QC}: 1}$ \\
\hline COR46K120 & $46: 3$ & WHOLE & 0.61 & -- & $0.61^{\mathrm{QC}: 1}$ \\
\hline COR46S4 & $46: 4$ & WHOLE & $<3$ & --- & $<3^{\mathrm{QC}: 1}$ \\
\hline COR46K121 & $46: 5$ & WHOLE & 0.39 & --- & $0.39^{\mathrm{eC}: 1}$ \\
\hline COR46K122 & $46: 6$ & WHOLE & 0.32 & -- & $0.32^{\mathrm{QC}: 1}$ \\
\hline COR46K 123 & 46: 7 & WHOLE & 0.4 & --- & $0.4^{\mathrm{QC}: 1}$ \\
\hline COR46S8 & $46: 8$ & WHOLE & $<2.5$ & --- & $<2.5^{\mathrm{QC:1}}$ \\
\hline COR46S9 & $46: 9$ & WHOLE & $<3.4$ & $-\cdots$ & $<3.4^{\mathrm{QC}: 1}$ \\
\hline
\end{tabular}


HNF-SD-WM-ER-372 Rev. 1

Table B2-63. Tank 241-T-104 Analytical Results: Toluene (VOA).

\begin{tabular}{|c|c|c|c|c|c|}
\hline Songl? & siriplo & $\begin{array}{l}\text { Sormole } \\
\text { rootion }\end{array}$ & 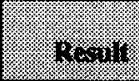 & Byplacate & 18 \\
\hline \multicolumn{2}{|c|}{ (3) } & 2. & 4010 & 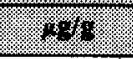 & \%lc \\
\hline COR45K108 & 45: 1 & WHOLE & 0.55 & $\cdots$ & $0.55^{\mathrm{QC}: 1}$ \\
\hline COR45K110 & $45: 3$ & WHOLE & 0.24 & -- & $0.24^{\mathrm{QC}: 1}$ \\
\hline COR45K 112 & $45: 5$ & WHOLE & 0.3 & -- & $0.3^{\mathrm{QC}: 1}$ \\
\hline COR45K114 & 45: 7 & WHOLE & 1.1 & -- & $1.1^{\mathrm{QC}: 1}$ \\
\hline COR45K116 & $45: 9$ & WHOLE & 0.62 & --- & $0.62^{\mathrm{QC}: 1}$ \\
\hline COR46S2 & $46: 2$ & WHOLE & 0.59 & --- & $0.59^{\mathrm{eC}: 1}$ \\
\hline COR46K120 & $46: 3$ & WHOLE & 0.69 & --- & $0.69^{\mathrm{QC}: 1}$ \\
\hline COR46S4 & $46: 4$ & WHOLE & 0.53 & -- & $0.53^{\mathrm{OC}: 1}$ \\
\hline COR46K121 & $46: 5$ & WHOLE & 0.47 & $\cdots$ & $0.47^{\mathrm{QC:1}}$ \\
\hline COR46K122 & $46: 6$ & WHOLE & 0.45 & --- & $0.45^{\mathrm{QC}: 1}$ \\
\hline COR46K123 & $46: 7$ & WHOLE & 0.43 & $\overline{---}$ & $0.43^{\mathrm{QC}: 1}$ \\
\hline COR46S8 & $46: 8$ & WHOLE & $<2.5$ & --- & $<2.5^{\mathrm{QC}: 1}$ \\
\hline COR46S9 & $46: 9$ & WHOLE & 0.52 & --- & $0.52^{\mathrm{QC}: 1}$ \\
\hline
\end{tabular}


HNF-SD-WM-ER-372 Rev. 1

Table B2-64. Tank 241-T-104 Analytical Results: Trimethyl Silanol (VOA).

\begin{tabular}{|c|c|c|c|c|c|}
\hline Solnyty & 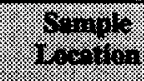 & 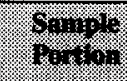 & resing & 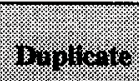 & ril:m \\
\hline \multicolumn{2}{|c|}{ Sin } & & $=40$ & 40 & 10 \\
\hline COR45K108 & 45: 1 & WHOLE & 6.8 & -- & $6.8^{\mathrm{QC}: 1}$ \\
\hline COR45K110 & $45: 3$ & WHOLE & 17 & -- & $17^{\mathrm{QC:1}}$ \\
\hline COR45K112 & $45: 5$ & WHOLE & 9.6 & --. & $9.6^{\mathrm{eC}: 1}$ \\
\hline COR45K114 & $45: 7$ & WHOLE & 12 & --- & $12^{\mathrm{OC:1}}$ \\
\hline COR45K116 & $45: 9$ & WHOLE & 20 & --- & $20^{\mathrm{QC}: 1}$ \\
\hline COR46S2 & 46: 2 & WHOLE & 14 & --- & $14^{\mathrm{QC:1}}$ \\
\hline COR46K120 & $46: 3$ & WHOLE & 18 & -- & $18^{\mathrm{QC}: 1}$ \\
\hline COR46S4 & $46: 4$ & WHOLE & 17 & $-\ldots$ & $17^{\mathrm{QC}: 1}$ \\
\hline COR46K121 & $46: 5$ & WHOLE & 20 & --- & $20^{\mathrm{QC}: 1}$ \\
\hline COR46K122 & 46: 6 & WHOLE & 28 & -- & $28^{\mathrm{QC:1}}$ \\
\hline COR46K123 & 46: 7 & WHOLE & 10 & -- & $10^{\mathrm{QC}: 1}$ \\
\hline COR46S8 & $46: 8$ & WHOLE & 13 & -- & $13^{\mathrm{QC:1}}$ \\
\hline COR46S9 & $46: 9$ & $\overline{\text { WHOLE }}$ & 31 & --- & $31^{\mathrm{QC}: 1}$ \\
\hline
\end{tabular}


HNF-SD-WM-ER-372 Rev. 1

Table B2-65. Tank 241-T-104 Analytical Results: Non-Detected VOA Analytes.

\begin{tabular}{|c|c|c|c|}
\hline (2) & 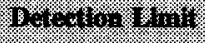 & \%, & 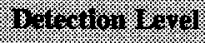 \\
\hline 1,1,1-Trichloroethane & $<3.4^{\mathrm{QC}: 1}$ & Chlorobenzene & $<3.4^{\mathrm{QC}: 1}$ \\
\hline 1,1,2,2-Tetrachloroethane & $<3.4^{\mathrm{QC}: 1}$ & Chloroethane & $<3.4^{\mathrm{QC}: 1}$ \\
\hline 1,1,2-Trichloroethane & $<3.4^{\mathrm{QC}: 1}$ & Chloroform & $<3.4^{\mathrm{QC}: 1}$ \\
\hline 1,1-Dichloroethane & $<3.4^{\mathrm{OC}: 1}$ & Chloromethane & $<6.8^{\mathrm{QC}: 1}$ \\
\hline 1,1-Dichloroethene & $<3.4^{\mathrm{QC}: 1}$ & Dibromochloromethane & $<3.4^{\mathrm{QC}: 1}$ \\
\hline 1,2-Dichloroethane & $<3.4^{Q \mathrm{CO}: 1}$ & Ethylbenzene & $<3.4^{\mathrm{QC}: 1}$ \\
\hline 1,2-Dichloroethylene & $<3.4^{\mathrm{QC:}: 1}$ & Hexone & $<6.8^{\mathrm{QC}: 1}$ \\
\hline 1,2-Dichloropropane & $<3.4^{\mathrm{QC:} 1}$ & Styrene & $<3.4^{\mathrm{QC}: 1}$ \\
\hline 2-Hexanone & $<6.8^{\mathrm{QC}: 1}$ & Tetrachloroethene & $<3.4^{\mathrm{QC}: 1}$ \\
\hline 2-Butanone & $<3.4^{\mathrm{QC:} 1}$ & Trichloroethene & $<3.4^{\mathrm{QC}: 1}$ \\
\hline Benzene & $<3.4^{\mathrm{QC:}: 1}$ & Vinyl acetate & $<6.8^{\mathrm{QC}: 1}$ \\
\hline Bromodichloromethane & $<3.4^{\mathrm{QC:}: 1}$ & Vinyl chloride & $<6.8^{\mathrm{QC}: 1}$ \\
\hline Bromoform & $<3.4^{\mathrm{QC}: 1}$ & Xylenes (total) & $<3.4^{\mathrm{QC}: 1}$ \\
\hline Bromomethane & $<6.8^{Q C: 1}$ & cis-1,3-Dichloropropene & $<3.4^{\mathrm{QC}: 1}$ \\
\hline Carbon disulfide & $<3.4^{\mathrm{QC:} 1}$ & $\begin{array}{l}\text { trans-1,3-Dichloropropen } \\
\mathrm{e}\end{array}$ & $<3.4^{\mathrm{QC}: 1}$ \\
\hline Carbon tetrachloride & $<3.4^{\mathrm{QC}: 1}$ & & \\
\hline
\end{tabular}


Table B2-66. Tank 241-T-104 Analytical Results: Carbonate (TIC).

\begin{tabular}{|c|c|c|c|c|c|}
\hline (1) & 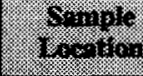 & 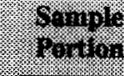 & $10=311$ & Q101\% & $4,6 \%$ \\
\hline \multicolumn{2}{|c|}{ 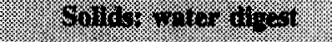 } & & 16.8: & $(10 \%$ & $6 \%$ \\
\hline 175 & \multirow{2}{*}{$\begin{array}{l}\text { Core } 45 \\
\text { Composite }\end{array}$} & WHOLE & $<500$ & $<500$ & $<500^{\mathrm{QC}: 2}$ \\
\hline 176 & & WHOLE & $<500$ & $<500$ & $<500^{20: 2}$ \\
\hline 179 & \multirow{2}{*}{$\begin{array}{l}\text { Core } 46 \\
\text { Composite }\end{array}$} & WHOLE & $<500$ & $<500$ & $<500^{\mathrm{Qc}: 2}$ \\
\hline 180 & & WHOLE & $<500$ & $<500$ & $<500^{Q \mathrm{C}: 2}$ \\
\hline
\end{tabular}

Table B2-67. Tank 241-T-104 Analytical Results: Total organic carbon (Furnace Oxidation).

\begin{tabular}{|c|c|c|c|c|c|}
\hline \%10\% & \%ongen. & 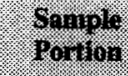 & $1+x=11$ & 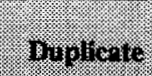 & 1041 \\
\hline \multicolumn{2}{|c|}{ 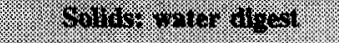 } & ?: & $14 \%$ & $4 \%$ & 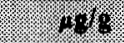 \\
\hline 175 & \multirow{2}{*}{$\begin{array}{l}\text { Core } 45 \\
\text { Composite }\end{array}$} & WHOLE & $<550$ & 706 & $<628^{\mathrm{QC}: 2}$ \\
\hline 176 & & WHOLE & $<550$ & $<550$ & $<550^{\mathrm{QC:}: 2}$ \\
\hline 179 & \multirow{2}{*}{$\begin{array}{l}\text { Core } 46 \\
\text { Composite }\end{array}$} & WHOLE & $<550$ & $<550$ & $<550^{\mathrm{QC:2}}$ \\
\hline 180 & & WHOLE & $<550$ & $<550$ & $<550^{\mathrm{QC}: 2}$ \\
\hline \multicolumn{2}{|c|}{ Whandy w w } & & 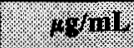 & 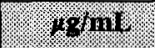 & $4 \%$ \\
\hline 204 & $\begin{array}{l}\text { Core } 46 \\
\text { Composite }\end{array}$ & $\mathrm{DL}$ & 473 & 429 & $451^{\mathrm{QC}: 2,3}$ \\
\hline
\end{tabular}


Table B2-68. Tank 241-T-104 Analytical Results: Americium-241 (GEA).

\begin{tabular}{|c|c|c|c|c|c|}
\hline Soniple & 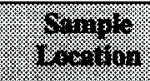 & $\begin{array}{l}\text { Sarmple } \\
\text { fioflion }\end{array}$ & Inasing & Hiviloni: & 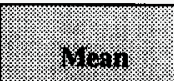 \\
\hline \multicolumn{2}{|c|}{ 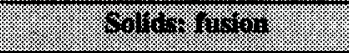 } & T: & \% & 1.640 & . \\
\hline 146 & \multirow[t]{2}{*}{ 46: 2} & WHOLE & 0.00816 & 0.00994 & 0.00905 \\
\hline 147 & & WHOLE & 0.0085 & 0.0108 & 0.00965 \\
\hline 175 & \multirow{2}{*}{\begin{tabular}{|l|} 
Core 45 \\
Composite
\end{tabular}} & WHOLE & 0.0108 & 0.0125 & $0.01165^{\mathrm{QC}: 2,4,8}$ \\
\hline 176 & & WHOLE & 0.013 & 0.0168 & 0.0149 \\
\hline 179 & \multirow{2}{*}{$\begin{array}{l}\text { Core } 46 \\
\text { Composite }\end{array}$} & WHOLE & 0.0146 & 0.0145 & 0.01455 \\
\hline 180 & & WHOLE & 0.0137 & 0.0175 & 0.0156 \\
\hline \multicolumn{2}{|c|}{ liguros water algest } & & 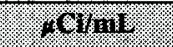 & (1) & . $01 \mathrm{~m}$ \\
\hline 204 & $\begin{array}{l}\text { Core } 46 \\
\text { Composite }\end{array}$ & DL & $<9.450 \mathrm{E}-04$ & $\begin{array}{l}< \\
9.600 \mathrm{E}-04\end{array}$ & $<9.525 \mathrm{E}-04$ \\
\hline
\end{tabular}

Table B2-69. Tank 241-T-104 Analytical Results: Cesium-137 (GEA).

\begin{tabular}{|c|c|c|c|c|c|}
\hline 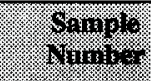 & Sempile & $\begin{array}{l}\text { Sarpole } \\
\text { rontion }\end{array}$ & 2.8.11 & 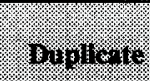 & 1. \\
\hline \multicolumn{2}{|c|}{ Sollat. Wugrom } & 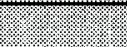 & $.0 \%$ & $10 \%$ & 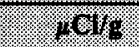 \\
\hline 146 & \multirow[t]{2}{*}{$46: 2$} & WHOLE & 0.222 & 0.232 & 0.227 \\
\hline 147 & & WHOLE & 0.222 & 0.22 & 0.221 \\
\hline 175 & \multirow{2}{*}{$\begin{array}{l}\text { Core } 45 \\
\text { Composite }\end{array}$} & WHOLE & 0.195 & 0.198 & 0.1965 \\
\hline 176 & & WHOLE & 0.193 & 0.188 & 0.1905 \\
\hline 179 & \multirow{2}{*}{$\begin{array}{l}\text { Core } 46 \\
\text { Composite }\end{array}$} & WHOLE & 0.199 & 0.201 & 0.2 \\
\hline 180 & & WHOLE & 0.21 & 0.209 & 0.2095 \\
\hline \multicolumn{2}{|c|}{ 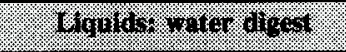 } & F) & 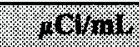 & mormis. & axhin \\
\hline 204 & $\begin{array}{l}\text { Core } 46 \\
\text { Composite }\end{array}$ & WHOLE & 0.0758 & 0.0808 & 0.0783 \\
\hline
\end{tabular}


HNF-SD-WM-ER-372 Rev. 1

Table B2-70. Tank 241-T-104 Analytical Results: Cobalt-60 (GEA).

\begin{tabular}{|c|c|c|c|c|c|}
\hline 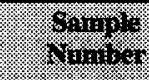 & 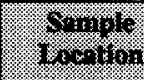 & 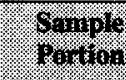 & o. & $\left.6 y_{3}\right)$ & 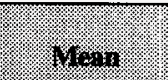 \\
\hline \multicolumn{2}{|c|}{ 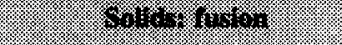 } & & $18 \%$ & $4 \%$ & r. \\
\hline 146 & \multirow[t]{2}{*}{ 46: 2} & WHOLE & $5.780 \mathrm{E}-04$ & $5.990 \mathrm{E}-04$ & 5.885E-04 \\
\hline 147 & & WHOLE & $5.200 \mathrm{E}-04$ & $6.560 \mathrm{E}-04$ & $5.880 \mathrm{E}-04$ \\
\hline 175 & \multirow{2}{*}{$\begin{array}{l}\text { Core } 45 \\
\text { Composite }\end{array}$} & WHOLE & $<2.270 \mathrm{E}-04$ & $<2.220 \mathrm{E}-04$ & $<2.245 \mathrm{E}-04$ \\
\hline 176 & & WHOLE & $<3.000 \mathrm{E}-04$ & $<2.430 \mathrm{E}-04$ & $<2.715 \mathrm{E}-04$ \\
\hline 179 & \multirow{2}{*}{$\begin{array}{l}\text { Core } 46 \\
\text { Composite }\end{array}$} & WHOLE & $<2.290 \mathrm{E}-04$ & $<2.810 \mathrm{E}-04$ & $<2.550 \mathrm{E}-04$ \\
\hline 180 & & WHOLE & $<2.950 \mathrm{E}-04$ & $<2.470 \mathrm{E}-04$ & $<2.710 \mathrm{E}-04$ \\
\hline \multicolumn{2}{|c|}{ 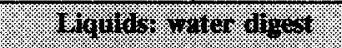 } & & $4 \times 1 / 111$ & $10 \%$ m1 & \% Yhall. \\
\hline 204 & $\begin{array}{l}\text { Core } 46 \\
\text { Composite }\end{array}$ & DL & $<1.310 \mathrm{E}-04$ & $<1.100 \mathrm{E}-04$ & $<1.205 \mathrm{E}-04$ \\
\hline
\end{tabular}

Table B2-71. Tank 241-T-104 Analytical Results: Europium-154 (GEA).

\begin{tabular}{|c|c|c|c|c|c|}
\hline 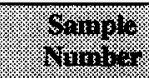 & 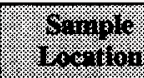 & 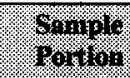 & 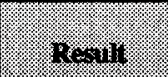 & Bollato & 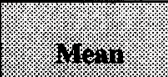 \\
\hline \multicolumn{2}{|c|}{ 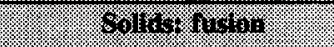 } & & $4 \%$ & \% & $1 \%$ \\
\hline 146 & \multirow[t]{2}{*}{ 46: 2} & WHOLE & 0.00224 & 0.00263 & 0.002435 \\
\hline 147 & & WHOLE & 0.0023 & 0.00249 & 0.002395 \\
\hline 175 & \multirow{2}{*}{$\begin{array}{l}\text { Core } 45 \\
\text { Composite }\end{array}$} & WHOLE & $<7.200 \mathrm{E}-04$ & $<7.700 \mathrm{E}-04$ & $<7.450 \mathrm{E}-04$ \\
\hline 176 & & WHOLE & 0.00414 & 0.00471 & 0.004425 \\
\hline 179 & \multirow{2}{*}{$\begin{array}{l}\text { Core } 46 \\
\text { Composite }\end{array}$} & WHOLE & 0.00379 & 0.00329 & 0.00354 \\
\hline 180 & & WHOLE & 0.00475 & 0.00393 & 0.00434 \\
\hline \multicolumn{2}{|c|}{ Gourt } & & $60 \% 311$ & $30 \%$ & (\%) \\
\hline 204 & $\begin{array}{l}\text { Core } 46 \\
\text { Composite }\end{array}$ & DL & $<3.470 \mathrm{E}-04$ & $<3.430 \mathrm{E}-04$ & $<3.450 \mathrm{E}-04$ \\
\hline
\end{tabular}


Table B2-72. Tank 241-T-104 Analytical Results: Europium-155 (GEA).

\begin{tabular}{|c|c|c|c|c|c|}
\hline $\begin{array}{l}\text { Selnole } \\
\text { fonor. }\end{array}$ & 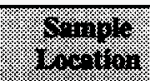 & $\begin{array}{l}\text { Suraplo } \\
\text { Eorition }\end{array}$ & q $=51$ & 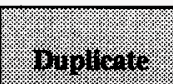 & $14 \times 2 n$ \\
\hline & $4 \%$ & & $6(2 \%)$ & 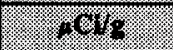 & 1.110 \\
\hline 146 & \multirow[t]{2}{*}{ 46: 2} & WHOLE & 0.0051 & 0.005 & 0.00505 \\
\hline 147 & & WHOLE & 0.00375 & 0.00382 & 0.003785 \\
\hline 175 & \multirow{2}{*}{$\begin{array}{l}\text { Core } 45 \\
\text { Composite }\end{array}$} & WHOLE & 0.00295 & 0.00354 & 0.003245 \\
\hline 176 & & WHOLE & 0.00429 & 0.00361 & 0.00395 \\
\hline 179 & \multirow{2}{*}{$\begin{array}{l}\text { Core } 46 \\
\text { Composite }\end{array}$} & WHOLE & 0.00269 & 0.00318 & 0.002935 \\
\hline 180 & & WHOLE & 0.00401 & 0.00308 & 0.003545 \\
\hline \multicolumn{2}{|c|}{ Viquler ritar diger? } & & HOMIII & HCVmis & irovinit \\
\hline 204 & $\begin{array}{l}\text { Core } 46 \\
\text { Composite }\end{array}$ & WHOLE & $<4.120 \mathrm{E}-04$ & $<3.970 \mathrm{E}-04$ & $<4.045 \mathrm{E}-04$ \\
\hline
\end{tabular}

Table B2-73. Tank 241-T-104 Analytical Results: Iodine-129 (I129).

\begin{tabular}{|c|c|c|c|c|c|}
\hline $\begin{array}{l}\text { Samplo } \\
\text { Ranime }\end{array}$ & 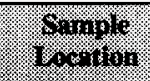 & $\begin{array}{l}\text { Simpite } \\
\text { forthis }\end{array}$ & Mesinin & miolicite & $\operatorname{lin}$ \\
\hline \multicolumn{2}{|c|}{ 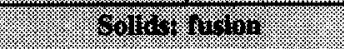 } & & 10.1. & (9.6\% & 1040 \\
\hline 175 & \multirow{2}{*}{$\begin{array}{l}\text { Core } 45 \\
\text { Composite }\end{array}$} & WHOLE & $<0.012$ & $<0.0119$ & $<0.01195$ \\
\hline 176 & & WHOLE & $<0.0118$ & $<0.0118$ & $<0.0118$ \\
\hline 179 & \multirow{2}{*}{$\begin{array}{l}\text { Core } 46 \\
\text { Composite }\end{array}$} & WHOLE & $<0.0261$ & $<0.0149$ & $<0.0205$ \\
\hline 180 & & WHOLE & $<0.0464$ & $<0.0127$ & $<0.02955$ \\
\hline
\end{tabular}


HNF-SD-WM-ER-372 Rev. 1

Table B2-74. Tank 241-T-104 Analytical Results: Carbon-14 (C14).

\begin{tabular}{|c|c|c|c|c|c|}
\hline 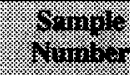 & 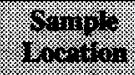 & 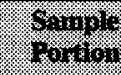 & bienaln & 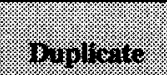 & 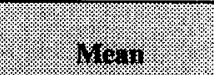 \\
\hline \multicolumn{2}{|c|}{ Son, } & & $\%$ & $8 \%$ & $14 \%$ \\
\hline 175 & \multirow{2}{*}{$\begin{array}{l}\text { Core } 45 \\
\text { Composite }\end{array}$} & WHOLE & -- & $<4.500 \mathrm{E}-05$ & $<4.500 \mathrm{E}-05^{\mathrm{QC}: 2,5}$ \\
\hline 176 & & WHOLE & $<4.500 \mathrm{E}-05$ & $<4.500 \mathrm{E}-05$ & $<4.500 \mathrm{E}-05^{\mathrm{QC} \cdot 5}$ \\
\hline 179 & \multirow{2}{*}{$\begin{array}{l}\text { Core } 46 \\
\text { Composite }\end{array}$} & WHOLE & $<4.500 \mathrm{E}-05$ & $<4.500 \mathrm{E}-05$ & $<4.500 \mathrm{E}-05^{Q \mathrm{C}: 5}$ \\
\hline 180 & & WHOLE & $<4.400 \mathrm{E}-05$ & $<4.400 \mathrm{E}-05$ & $<4.400 \mathrm{E}-05^{Q \mathrm{C}-5}$ \\
\hline
\end{tabular}

Table B2-75. Tank 241-T-104 Analytical Results: Tritium (Liq. Scin.).

\begin{tabular}{|c|c|c|c|c|c|}
\hline$\frac{1}{4013}$ & 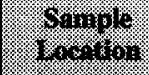 & 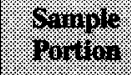 & $14=11$ & $84=81418$ & Mosin \\
\hline \multicolumn{2}{|c|}{ 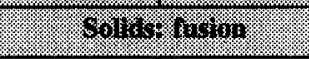 } & & \% & \%) & \%) \\
\hline 175 & \multirow{2}{*}{$\begin{array}{l}\text { Core } 45 \\
\text { Composite }\end{array}$} & WHOLE & $<3.360 \mathrm{E}-04$ & $<3.360 \mathrm{E}-04$ & $<3.360 \mathrm{E}-04^{\mathrm{QC}: 5}$ \\
\hline 176 & & WHOLE & $<3.370 \mathrm{E}-04$ & $<3.380 \mathrm{E}-04$ & $<3.375 \mathrm{E}-04^{\mathrm{QC}: 5}$ \\
\hline 179 & \multirow{2}{*}{$\begin{array}{l}\text { Core } 46 \\
\text { Composite }\end{array}$} & WHOLE & $<3.360 \mathrm{E}-04$ & $<3.370 \mathrm{E}-04$ & $<3.365 \mathrm{E}-04^{\mathrm{QC}: 5}$ \\
\hline 180 & & WHOLE & $<3.31$ & $<3.340 \mathrm{E}-04$ & $<1.65517^{\mathrm{QC}: 5}$ \\
\hline
\end{tabular}

Table B2-76. Tank 241-T-104 Analytical Results: Selenium-79 (Se79).

\begin{tabular}{|c|c|c|c|c|c|}
\hline Whing & 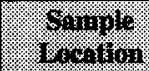 & 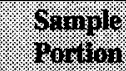 & $08 \times 111$ & Dopllate & $4 \%$ a13 \\
\hline \multicolumn{2}{|c|}{ 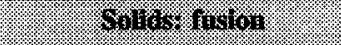 } & & 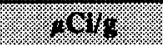 & $1 \%$ & (1) \\
\hline 175 & \multirow{2}{*}{$\begin{array}{l}\text { Core } 45 \\
\text { Composite }\end{array}$} & WHOLE & $<1.730 \mathrm{E}-04$ & $<16,600$ & $<8,300^{\mathrm{QC:} 6}$ \\
\hline 176 & & WHOLE & $<1.670 \mathrm{E}-04$ & $<1.750 \mathrm{E}-04$ & $<1.710 \mathrm{E}-04$ \\
\hline 179 & \multirow{2}{*}{$\begin{array}{l}\text { Core } 46 \\
\text { Composite }\end{array}$} & WHOLE & $<1.370 \mathrm{E}-04$ & $<1.410 \mathrm{E}-04$ & $<1.390 \mathrm{E}-04$ \\
\hline 180 & & WHOLE & $<1.320 \mathrm{E}-04$ & $<1.290 \mathrm{E}-04$ & $<1.305 \mathrm{E}-04$ \\
\hline
\end{tabular}


HNF-SD-WM-ER-372 Rev. 1

Table B2-77. Tank 241-T-104 Analytical Results: Technetium-99 (Te).

\begin{tabular}{|c|c|c|c|c|c|}
\hline 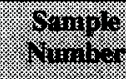 & 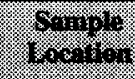 & 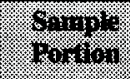 & 16.911 & 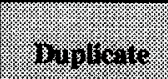 & Hes \\
\hline 4 & 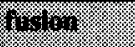 & & 4 & $4 \%$ & 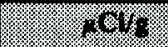 \\
\hline 175 & \multirow{2}{*}{$\begin{array}{l}\text { Core } 45 \\
\text { Composite }\end{array}$} & WHOLE & 5.950E-04 & $5.630 \mathrm{E}-04$ & $5.790 \mathrm{E}-04$ \\
\hline 176 & & WHOLE & $<4.710 \mathrm{E}-04$ & $<4.630 \mathrm{E}-04$ & $<4.670 \mathrm{E}-04$ \\
\hline 179 & \multirow{2}{*}{$\begin{array}{l}\text { Core } 46 \\
\text { Composite }\end{array}$} & WHOLE & $<7.230 \mathrm{E}-04$ & $<7.590 \mathrm{E}-04$ & $<7.410 \mathrm{E}-04$ \\
\hline 180 & & WHOLE & $<7.250 \mathrm{E}-04$ & $<7.380 \mathrm{E}-04$ & $<7.315 \mathrm{E}-04$ \\
\hline
\end{tabular}

Table B2-78. Tank 241-T-104 Analytical Results: Strontium-90 (Sr).

\begin{tabular}{|c|c|c|c|c|c|}
\hline 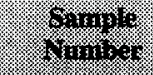 & (2) & . & 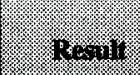 & 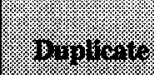 & 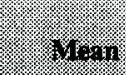 \\
\hline \multicolumn{2}{|c|}{ 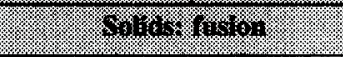 } & & $6 \%$ & (x) & $4 \%$ \\
\hline 175 & \multirow{2}{*}{$\begin{array}{l}\text { Core } 45 \\
\text { Composite }\end{array}$} & WHOLE & 2.33 & 2.35 & $2.34^{\mathrm{QC}: 3}$ \\
\hline 176 & & WHOLE & 2.4 & 2.49 & 2.445 \\
\hline 179 & \multirow{2}{*}{$\begin{array}{l}\text { Core } 46 \\
\text { Composite }\end{array}$} & WHOLE & 2.72 & 2.76 & $2.74^{\mathrm{QC}: 4}$ \\
\hline 180 & & WHOLE & 2.98 & 3.02 & 3 \\
\hline
\end{tabular}


HNF-SD-WM-ER-372 Rev. 1

Table B2-79. Tank 241-T-104 Analytical Results: Total Beta

\begin{tabular}{|c|c|c|c|c|c|}
\hline 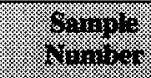 & 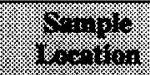 & Soringul & Per.ant & 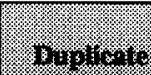 & 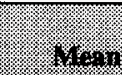 \\
\hline \multicolumn{2}{|c|}{ 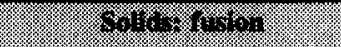 } & ?য়ায় & 46 & $.6 \%$ & $2 \%$ \\
\hline 175 & \multirow{2}{*}{$\begin{array}{l}\text { Core 45 } \\
\text { Composite }\end{array}$} & WHOLE & 6.55 & 6.67 & $6.61^{\mathrm{QC}: 4}$ \\
\hline 176 & & WHOLE & 6.87 & 6.98 & $6.925^{\mathrm{QC}: 4}$ \\
\hline 179 & \multirow{2}{*}{$\begin{array}{l}\text { Core } 46 \\
\text { Composite }\end{array}$} & WHOLE & 7.74 & 7.59 & $7.665^{\mathrm{QC}: 4}$ \\
\hline 180 & & WHOLE & 9.22 & 9.13 & $9.175^{\mathrm{QC}: 4}$ \\
\hline
\end{tabular}

Table B2-80. Tank 241-T-104 Analytical Results: Americium-241 (Alpha Spec).

\begin{tabular}{|c|c|c|c|c|c|}
\hline 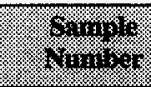 & 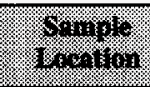 & Somplo & 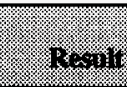 & Diplicire & Vian \\
\hline 7. & Jisios & & (2614 & (a) & net: \\
\hline 175 & \multirow{2}{*}{$\begin{array}{l}\text { Core } 45 \\
\text { Composite }\end{array}$} & WHOLE & 0.0183 & 0.0204 & $0.01935^{\circ \mathrm{C}: 2,4,8}$ \\
\hline 176 & & WHOLE & 0.0163 & 0.0159 & $0.0161^{\mathrm{QC}: 4,8}$ \\
\hline 179 & \multirow{2}{*}{$\begin{array}{l}\text { Core } 46 \\
\text { Composite }\end{array}$} & WHOLE & 0.0159 & 0.0154 & 0.01565 \\
\hline 180 & & WHOLE & 0.017 & 0.019 & 0.018 \\
\hline
\end{tabular}


Table B2-81. Tank 241-T-104 Analytical Results: Plutonium-238 (Alpha Spec).

\begin{tabular}{|c|c|c|c|c|c|}
\hline 等 & 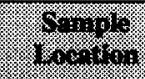 & 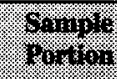 & 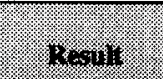 & $140 \%, 10$. & $6+1$ \\
\hline \multicolumn{2}{|c|}{ 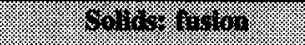 } & & $1 \%$ & \% & 46111 \\
\hline 175 & \multirow{2}{*}{$\begin{array}{l}\text { Core } 45 \\
\text { Composite }\end{array}$} & WHOLE & $<0.018$ & $<0.0179$ & $<0.01795^{\mathrm{CC}: 2}$ \\
\hline 176 & & WHOLE & $<0.018$ & $<0.018$ & $<0.018^{\mathrm{QC}-2,8}$ \\
\hline 179 & \multirow{2}{*}{$\begin{array}{l}\text { Core } 46 \\
\text { Composite }\end{array}$} & WHOLE & $<0.0179$ & 0.018 & $<0.01795^{\mathrm{QC}: 4,6}$ \\
\hline 180 & & WHOLE & $<0.0179$ & $<0.0178$ & $<0.01785$ \\
\hline \multicolumn{2}{|c|}{ 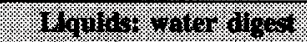 } & & $10 \times 1,11 \%$ & 1011,14 & 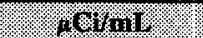 \\
\hline 204 & $\begin{array}{l}\text { Core } 46 \\
\text { Composite }\end{array}$ & DL & $<9.010 \mathrm{E}-05$ & $<9.010 \mathrm{E}-05$ & $<9.010 \mathrm{E}-05^{\mathrm{QC}: 8}$ \\
\hline
\end{tabular}

Table B2-82. Tank 241-T-104 Analytical Results: Plutonium-239/240 (Alpha Spec).

\begin{tabular}{|c|c|c|c|c|c|}
\hline o. & 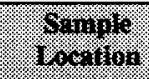 & 6. & 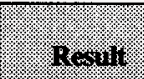 & 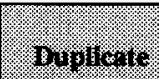 & Menir \\
\hline \multicolumn{2}{|c|}{ 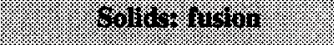 } & & $\%$ & 19. & 18 \\
\hline 175 & \multirow{2}{*}{$\begin{array}{l}\text { Core } 45 \\
\text { Composite }\end{array}$} & WHOLE & 0.141 & 0.15 & $0.1455^{\mathrm{QC:2,4}}$ \\
\hline 176 & & WHOLE & 0.152 & 0.142 & $0.147^{Q \mathrm{C}: 4.8}$ \\
\hline 179 & \multirow{2}{*}{$\begin{array}{l}\text { Core } 46 \\
\text { Composite }\end{array}$} & WHOLE & 0.143 & 0.124 & $0.1335^{\mathrm{QC}: 4,6}$ \\
\hline 180 & & WHOLE & 0.136 & 0.13 & 0.133 \\
\hline \multicolumn{2}{|c|}{ fragles } & & 4,1911 & 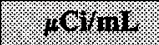 & moln \\
\hline 204 & $\begin{array}{l}\text { Core } 46 \\
\text { Composite }\end{array}$ & $\mathrm{DL}$ & 0.00844 & 0.00943 & $0.008935^{\mathrm{Qc:8}}$ \\
\hline
\end{tabular}


Table B2-83. Tank 241-T-104 Analytical Results: Neptunium-237 (Np237).

\begin{tabular}{|c|c|c|c|c|c|}
\hline 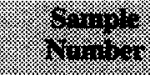 & 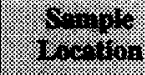 & 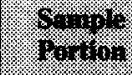 & $2,6+11$ & 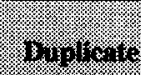 & $6 \%=11$ \\
\hline \multicolumn{2}{|c|}{ 6.8. } & & $\%$ & 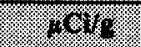 & 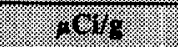 \\
\hline 175 & \multirow{2}{*}{$\begin{array}{l}\text { Core } 45 \\
\text { Composite }\end{array}$} & WHOLE & $<0.0216$ & $<0.0215$ & $<0.02155^{\mathrm{QC}: 4}$ \\
\hline 176 & & WHOLE & $<0.0108$ & $<0.0108$ & $<0.0108^{\mathrm{QC}: 4}$ \\
\hline 179 & \multirow{2}{*}{$\begin{array}{l}\text { Core } 46 \\
\text { Composite }\end{array}$} & WHOLE & $<0.0269$ & $<0.0108$ & $<0.01885^{\mathrm{QC}: 4}$ \\
\hline 180 & & WHOLE & 0.137 & $<0.0213$ & $<0.07915$ \\
\hline
\end{tabular}

Table B2-84. Tank 241-T-104 Analytical Results: Pu238 to Pu ratio (Mass Spec.).

\begin{tabular}{|c|c|c|c|c|c|}
\hline \%) & 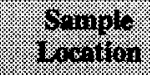 & $\frac{1}{401}$ & 180,11 & $(14,1)$ & Mring \\
\hline \multicolumn{2}{|c|}{ 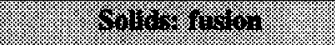 } & & 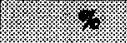 & \% & $\%$ \\
\hline 93-1807-H1 & \multirow[t]{2}{*}{$45: 9$} & WHOLE & 0.018 & 0.015 & $0.0165^{Q C: 4}$ \\
\hline 93-1808-H1 & & WHOLE & 0.044 & 0.03 & $0.037^{\mathrm{QC:}: 4}$ \\
\hline 93-1809-H1 & \multirow{2}{*}{$\begin{array}{l}\text { Core } 45 \\
\text { Composite }\end{array}$} & WHOLE & 0.003 & 0.004 & $0.0035^{\mathrm{QC}: 4}$ \\
\hline 93-1810-H1 & & WHOLE & 0.004 & 0.004 & $0.004^{\mathrm{QC}: 4}$ \\
\hline 93-1811-H1 & \multirow{2}{*}{$\begin{array}{l}\text { Core } 46 \\
\text { Composite }\end{array}$} & WHOLE & 0.006 & 0.006 & $0.006^{\mathrm{QC} / 4}$ \\
\hline $93-1812-\mathrm{H} 1$ & & WHOLE & 0.006 & 0.007 & $0.0065^{Q C: 4}$ \\
\hline
\end{tabular}


Table B2-85. Tank 241-T-104 Analytical Results: Pu239 to Pu ratio (Mass Spec.).

\begin{tabular}{|c|c|c|c|c|c|}
\hline 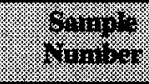 & 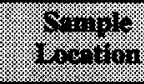 & 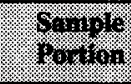 & 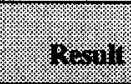 & $81 \% 16$ & 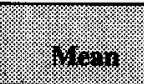 \\
\hline \multicolumn{2}{|c|}{ 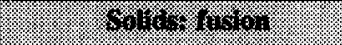 } & & \% & \% & 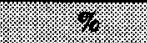 \\
\hline 93-1807-H1 & \multirow[t]{2}{*}{$45: 9$} & WHOLE & 98.0454 & 98.1677 & $98.1065^{\mathrm{QC}: 4}$ \\
\hline 93-1808-H1 & & WHOLE & 97.4645 & 97.577 & $97.5207^{\mathrm{QC}: 4}$ \\
\hline 93-1809-H1 & \multirow{2}{*}{$\begin{array}{l}\text { Core } 45 \\
\text { Composite }\end{array}$} & WHOLE & 96.9134 & 97.0094 & $96.9614^{\mathrm{QC:4}}$ \\
\hline 93-1810-H1 & & WHOLE & 96.8341 & 96.8423 & $96.8382^{\mathrm{QC}: 4}$ \\
\hline 93-1811-H1 & \multirow{2}{*}{$\begin{array}{l}\text { Core } 46 \\
\text { Composite }\end{array}$} & WHOLE & 96.6298 & 96.6803 & $96.6551^{\text {QC:4 }}$ \\
\hline 93-1812-H1 & & WHOLE & 96.5371 & 96.6492 & $96.5931^{\text {QC:4 }}$ \\
\hline
\end{tabular}

Table B2-86. Tank 241-T-104 Analytical Results: Pu240 to Pu ratio (Mass Spec.).

\begin{tabular}{|c|c|c|c|c|c|}
\hline \% & 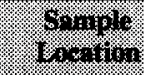 & ximis & ieses.14 & B 1301096 & 1840 \\
\hline \multicolumn{2}{|c|}{ 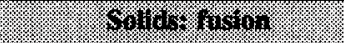 } & & $\%$ & \% & $\%$ \\
\hline 93-1807-H1 & \multirow[t]{2}{*}{$45: 9$} & WHOLE & 1.7948 & 1.7279 & $1.76135^{\mathrm{QC}: 4}$ \\
\hline 93-1808-H1 & & WHOLE & 2.3497 & 2.2204 & $2.28505^{\mathrm{QC:4}}$ \\
\hline $93-1809-\mathrm{H} 1$ & \multirow{2}{*}{$\begin{array}{l}\text { Core } 45 \\
\text { Composite }\end{array}$} & WHOLE & 3.0423 & 2.9444 & $2.99335^{\mathrm{QC}: 4}$ \\
\hline $93-1810-\mathrm{H} 1$ & & WHOLE & 3.132 & 3.1254 & $3.1287^{\mathrm{QC}: 4}$ \\
\hline $93-1811-H 1$ & \multirow{2}{*}{$\begin{array}{l}\text { Core } 46 \\
\text { Composite }\end{array}$} & WHOLE & 3.3115 & 3.2622 & $3.28685^{\mathrm{QC}: 4}$ \\
\hline 93-1812-H1 & & WHOLE & 3.4061 & 3.3003 & $3.3532^{\mathrm{QC}: 4}$ \\
\hline
\end{tabular}


Table B2-87. Tank 241-T-104 Analytical Results: Pu24l to Pu ratio (Mass Spec.).

\begin{tabular}{|c|c|c|c|c|c|}
\hline 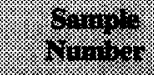 & 40 & 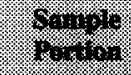 & $4=\infty 13$ & 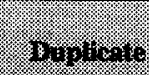 & 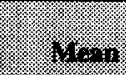 \\
\hline \multicolumn{2}{|c|}{ 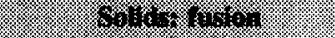 } & & 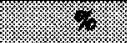 & (2) & $\%$ \\
\hline 93-1807-H1 & \multirow[t]{2}{*}{$45: 9$} & WHOLE & 0.044 & 0.037 & $0.0405^{Q C: 4}$ \\
\hline 93-1808-H1 & & WHOLE & 0.073 & 0.059 & $0.066^{\mathrm{QC:4}}$ \\
\hline $93-1809-\mathrm{H} 1$ & \multirow{2}{*}{$\begin{array}{l}\text { Core } 45 \\
\text { Composite }\end{array}$} & WHOLE & 0.036 & 0.032 & $0.034^{\mathrm{QC}: 4}$ \\
\hline $93-1810-\mathrm{H} 1$ & & WHOLE & 0.027 & 0.028 & $0.0275^{\mathrm{QC}: 4}$ \\
\hline $93-1811-\mathrm{H} 1$ & \multirow{2}{*}{$\begin{array}{l}\text { Core } 46 \\
\text { Composite }\end{array}$} & WHOLE & 0.038 & 0.039 & $0.0385^{\mathrm{QC} 4}$ \\
\hline 93-1812-H1 & & WHOLE & 0.054 & 0.065 & $0.0595^{\mathrm{QC}: 4}$ \\
\hline
\end{tabular}

Table B2-88. Tank 241-T-104 Analytical Results: Pu242 to Pu ratio (Mass Spec.).

\begin{tabular}{|c|c|c|c|c|c|}
\hline | & (2) & Oranger & $1+2+311$ & 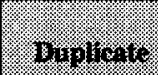 & 416 \\
\hline \multicolumn{2}{|c|}{ 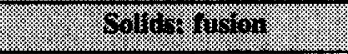 } & & $\%$ & 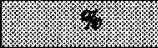 & $\%$ \\
\hline 93-1807-H1 & \multirow[t]{2}{*}{$45: 9$} & WHOLE & 0.097 & 0.053 & $0.075^{\mathrm{QC}: 4}$ \\
\hline 93-1808-H1 & & WHOLE & 0.069 & 0.114 & $0.0915^{\mathrm{QC}: 4}$ \\
\hline $93-1809-\mathrm{H} 1$ & \multirow{2}{*}{$\begin{array}{l}\text { Core } 45 \\
\text { Composite }\end{array}$} & WHOLE & 0.005 & 0.011 & $0.008^{\mathrm{QC}: 4}$ \\
\hline 93-1810-H1 & & WHOLE & 0.003 & & $0.003^{\mathrm{QC}: 4}$ \\
\hline $93-1811-\mathrm{H} 1$ & $\begin{array}{l}\text { Core } 46 \\
\text { Composite }\end{array}$ & WHOLE & 0.015 & 0.013 & $0.014^{\mathrm{QC} \cdot 4}$ \\
\hline
\end{tabular}


Table B2-89. Tank 241-T-104 Analytical Results: U234 to U ratio (Mass Spec.).

\begin{tabular}{|c|c|c|c|c|c|}
\hline 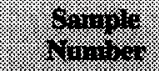 & $\frac{1}{4093}$ & 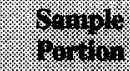 & $14=11$ & 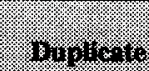 & (3) \\
\hline \multicolumn{2}{|c|}{ 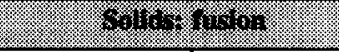 } & & $\%$ & 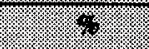 & \% \\
\hline 93-1807-H1 & \multirow[t]{2}{*}{$45: 9$} & WHOLE & 0.008 & 0.006 & $0.007^{\mathrm{QC}: 4}$ \\
\hline $93-1808-\mathrm{H} 1$ & & WHOLE & 0.008 & 0.011 & $0.0095^{\mathrm{QC}: 4}$ \\
\hline 93-1809-H1 & \multirow{2}{*}{$\begin{array}{l}\text { Core } 45 \\
\text { Composite }\end{array}$} & WHOLE & 0.005 & 0.009 & $0.007^{\mathrm{QC}: 4}$ \\
\hline 93-1810-H1 & & WHOLE & 0.005 & 0.015 & $0.01^{\mathrm{QC}: 4}$ \\
\hline 93-1811-H1 & \multirow{2}{*}{$\begin{array}{l}\text { Core } 46 \\
\text { Composite }\end{array}$} & WHOLE & 0.006 & 0.006 & $0.006^{\mathrm{QC}: 4}$ \\
\hline 93-1812-H1 & & WHOLE & 0.005 & 0.007 & $0.006^{\mathrm{QC}: 4}$ \\
\hline
\end{tabular}

Table B2-90. Tank 241-T-104 Analytical Results: U235 to U ratio (Mass Spec.).

\begin{tabular}{|c|c|c|c|c|c|}
\hline (4) & 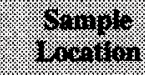 & 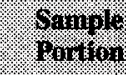 & 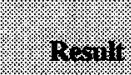 & 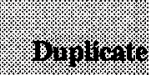 & YIFa \\
\hline \multicolumn{2}{|c|}{ 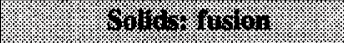 } & & 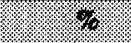 & 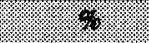 & \% \\
\hline 93-1807-H1 & \multirow[t]{2}{*}{$45: 9$} & WHOLE & 0.6896 & 0.6973 & $0.69345^{Q C \cdot 4}$ \\
\hline 93-1808-H1 & & WHOLE & 0.6996 & 0.7139 & $0.70675^{Q C: 4}$ \\
\hline 93-1809-H1 & \multirow{2}{*}{$\begin{array}{l}\text { Core } 45 \\
\text { Composite }\end{array}$} & WHOLE & 0.6813 & 0.6855 & $0.6834^{Q C: 4}$ \\
\hline $93-1810-\mathrm{H} 1$ & & WHOLE & 0.6782 & 0.6835 & $0.68085^{\mathrm{QC}: 4}$ \\
\hline 93-1811-H1 & \multirow{2}{*}{$\begin{array}{l}\text { Core } 46 \\
\text { Composite }\end{array}$} & WHOLE & 0.6746 & 0.6686 & $0.6716^{\mathrm{QC}: 4}$ \\
\hline 93-1812-H1 & & WHOLE & 0.6654 & 0.6583 & $0.66185^{\mathrm{QC}: 4}$ \\
\hline
\end{tabular}


Table B2-91. Tank 241-T-104 Analytical Results: U236 to U ratio (Mass Spec.).

\begin{tabular}{|c|c|c|c|c|c|}
\hline . & 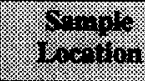 & 3yon & Plonil & Hollory & 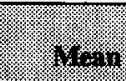 \\
\hline \multicolumn{2}{|c|}{ 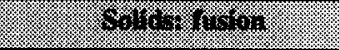 } & & 8 & $\%$ & $\%$ \\
\hline 93-1807-H1 & \multirow[t]{2}{*}{$45: 9$} & WHOLE & 0.006 & 0.005 & $0.0055^{Q C: 4}$ \\
\hline 93-1808-H1 & & WHOLE & 0.003 & 0.009 & $0.006^{\mathrm{QC:4}}$ \\
\hline 93-1809-H1 & \multirow{2}{*}{$\begin{array}{l}\text { Core } 45 \\
\text { Composite }\end{array}$} & WHOLE & 0.007 & 0.009 & $0.008^{\mathrm{QC}: 4}$ \\
\hline 93-1810-H1 & & WHOLE & 0.004 & 0.005 & $0.0045^{Q \mathrm{QC}: 4}$ \\
\hline 93-1811-H1 & \multirow{2}{*}{$\begin{array}{l}\text { Core } 46 \\
\text { Composite }\end{array}$} & WHOLE & 0.006 & 0.007 & $0.0065^{\mathrm{QC}: 4}$ \\
\hline $93-1812-\mathrm{H} 1$ & & WHOLE & 0.007 & 0.009 & $0.008^{Q C: 4}$ \\
\hline
\end{tabular}

Table B2-92. Tank 241-T-104 Analytical Results: U238 to U ratio (Mass Spec.).

\begin{tabular}{|c|c|c|c|c|c|}
\hline . & 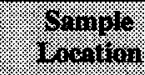 & Wocking & $10=411$ & 1001640 & \%gra \\
\hline \multicolumn{2}{|c|}{ 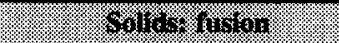 } & & \% & \% & 8 \\
\hline 93-1807-H1 & \multirow[t]{2}{*}{$45: 9$} & WHOLE & 99.2969 & 99.2912 & $99.294^{\mathrm{QC}: 4}$ \\
\hline 93-1808-H1 & & WHOLE & 99.2894 & 99.2659 & $99.2776^{\mathrm{QC}: 4}$ \\
\hline 93-1809-H1 & \multirow{2}{*}{$\begin{array}{l}\text { Core } 45 \\
\text { Composite }\end{array}$} & WHOLE & 99.3065 & 99.2959 & $99.3012^{\mathrm{QC}: 4}$ \\
\hline 93-1810-H1 & & WHOLE & 99.3122 & 99.2963 & $99.3042^{\mathrm{QC}: 4}$ \\
\hline 93-1811-H1 & \multirow{2}{*}{$\begin{array}{l}\text { Core } 46 \\
\text { Composite }\end{array}$} & WHOLE & 99.3128 & 99.3182 & $99.3155^{\mathrm{QC}: 4}$ \\
\hline 93-1812-H1 & & WHOLE & 99.3228 & 99.326 & $99.3244^{\mathrm{QC}: 4}$ \\
\hline
\end{tabular}


Table B2-93. 1996 Evaluation of Tank Headspace Flammability. ${ }^{1}$

\begin{tabular}{|c|c|c|c|}
\hline Hapor & 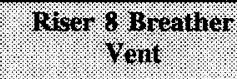 & Riser 8 & 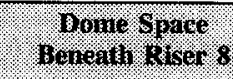 \\
\hline TOC & 0 ppmv & $<2$ ppmv & 4 ppmv \\
\hline Flammability & 0 percent of LFL & 0 percent of LFL & 0 percent of LFL \\
\hline $\mathrm{O}_{2}$ & $20.9 \%$ & $20.9 \%$ & $20.9 \%$ \\
\hline $\mathrm{NH}_{3}$ & 0 ppmv & $<5$ ppmv & $50 \mathrm{ppmv}$ \\
\hline
\end{tabular}

Note:

'WHC (1996)

Table B2-94. Physical Properties of 1979 Core Sample. ${ }^{1}$

\begin{tabular}{|c|c|c|c|c|}
\hline Gore segringit & 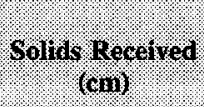 & ming gensis? & $\left\{\begin{array}{l}6 \\
.\end{array}\right.$ & Oranalie \\
\hline 1 & 0 & 0 & --- & $\cdots$ \\
\hline 2 & 35.6 & 1.39 & 57.0 & 120 \\
\hline 3 & 40.6 & 1.27 & 59.0 & 150 \\
\hline 4 & 40.6 & 1.35 & 58.0 & 120 \\
\hline 5 & 43.2 & 1.36 & 61.0 & 150 \\
\hline 6 & 45.7 & 1.35 & 62.0 & 125 \\
\hline 7 & 45.7 & 1.28 & 64.0 & 125 \\
\hline 8 & 48.3 & 1.28 & 62.0 & 90 \\
\hline 9 & 50.8 & 1.30 & 61.0 & 70 \\
\hline Composite & $\mathrm{n} / \mathrm{a}$ & 1.31 & 62.0 & $n / a$ \\
\hline
\end{tabular}

Notes:

$\mathrm{n} / \mathrm{a}=$ not applicable

'Horton (1979) 
HNF-SD-WM-ER-372 Rev. 1

Table B2-95. Chemical Characteristics of Composite of 1979 Core Sample.'

\begin{tabular}{|c|c|c|}
\hline Eomponent & $\begin{array}{l}\text { Water solwble } \\
\text { (weight percent) }\end{array}$ & $\begin{array}{l}\text { Water Imsaloble } \\
\text { (weght percent) }\end{array}$ \\
\hline Aluminum & NR & 1.2 \\
\hline Bismuth & $\mathrm{BDL}$ & 1.3 \\
\hline Carbonate & 0.12 & NR \\
\hline Chromium & 0.02 & 0.1 \\
\hline Chloride & 0.12 & NR \\
\hline Fluoride & 0.4 & 1.6 \\
\hline Iron & NR & 0.2 \\
\hline \begin{tabular}{|l|} 
Mercury \\
\end{tabular} & NR & ID \\
\hline Lanthanum & NR & ID \\
\hline Manganese & NR & 0.01 \\
\hline Nickel & 0.0004 & 1.3 \\
\hline Lead & BDL & NR \\
\hline \begin{tabular}{|l} 
Nitrate \\
\end{tabular} & 6.9 & $<1.0$ \\
\hline Sodium & 13.0 & 4.3 \\
\hline \begin{tabular}{|l} 
Hydroxide \\
\end{tabular} & $\mathrm{pH} 8.0$ & NR \\
\hline \begin{tabular}{|l|} 
Phosphate \\
\end{tabular} & 1.4 & 7.8 \\
\hline Sulfate & $\overline{\mathrm{BDL}}$ & BDL \\
\hline Silicate & ID & 0.8 \\
\hline Cadmium & NR & 0.003 \\
\hline TOC & $0.00290 \mathrm{~g} / \mathrm{g}$ & $0.102 \mathrm{~g} / \mathrm{g}$ \\
\hline${ }^{239} \mathrm{Pu}$ & $1.12 \mathrm{E}-10 \mathrm{~g} / \mathrm{g}$ & $4.06 \mathrm{E}-06 \mathrm{~g} / \mathrm{g}$ \\
\hline${ }^{241} \mathrm{Am}$ & NR & $2.70 \mathrm{E}-07 \mathrm{~g} / \mathrm{g}$ \\
\hline $\mathrm{U}^{6+}$ & $2.64 \mathrm{E}-06 \mathrm{~g} / \mathrm{g}$ & $7.40 \mathrm{E}-05 \mathrm{~g} / \mathrm{g}$ \\
\hline${ }^{89 / 90} \mathrm{Sr}$ & $7.47 \mathrm{E}-04 \mu \mathrm{Ci} / \mathrm{g}$ & $5.0 \mu \mathrm{Ci} / \mathrm{g}$ \\
\hline${ }^{137} \mathrm{Cs}$ & $0.511 \mu \mathrm{Ci} / \mathrm{g}$ & $1.30 \mu \mathrm{Ci} / \mathrm{g}$ \\
\hline
\end{tabular}

Notes:

$\begin{array}{ll}\mathrm{NR} & =\text { Not reported } \\ \mathrm{ID} & =\text { lncomplete data } \\ \mathrm{BDL} & =\text { Below detection limit }\end{array}$

'Horton (1979) 


\section{B3.0 ASSESSMENT OF CHARACTERIZATION RESULTS}

The purpose of this chapter is to discuss the overall quality and consistency of the current sampling results for tank 241-T-104, and to present the results of the calculation of an analytical-based mean concentration for the tank.

This section also evaluates sampling and analysis factors that may impact interpretation of the data. These factors are used to assess the overall quality and consistency of the data and to identify any limitations in the use of the data.

\section{B3.1 FIELD OBSERVATIONS}

The sampler for segment 1 for core 46 was empty and segment 1 of core 45 contained only a small amount of sample. This was most likely because of a mismeasurement of the height of the waste prior to sampling and not because of any failure of the sampling process itself. the remainder of the segments for both cores exhibited very good recovery. All samples but one (segment 7 of core 46) which contained drainable liquids were contaminated with hydrostatic head fluid (normal paraffin hydrocarbon). This complicated the SVOA and VOA analyses in that a cleanup procedure had to be performed prior to analysis by gas chromatography.

\section{B3.2 QUALITY CONTROL ASSESSMENT}

The quality control assessment of the 1992 analytical results included an evaluation of the completeness of the chain of custody forms, performance of the analyses within the required time limits, initial and continuing calibration of analytical and laboratory instruments, performance of analysis-specific quality control tests i.e., serial dilutions, appropriate standard recoveries, spike recoveries, duplicate analyses, and blanks that were performed in conjunction with the chemical analyses. All the pertinent quality control tests were conducted on the 1992 core samples, allowing a full assessment regarding the accuracy and precision of the data (Pool 1994). Hill et al. (1991) established the specific criteria for all analytes. Sample and duplicate pairs that had one or more QC results outside the specified criteria were identified by footnotes in the data summary tables. Nearly all analytes exhibited one or more quality control discrepancies, ranging from excessive holding times, to standard or spike recoveries outside the limits. A qualitative judgment was made for these discrepancies, based on the requirements of Hill et al. (1991), and further guided by Silvers (1991), Smith (1992), and Jones (1993). A large majority of the data that exhibited qualifications were deemed "estimated." These qualifications impact the data very little. Of more serious impact were the qualifications of some analytes as "rejected." The following discussion is limited to those analytes that exhibited "rejected" analytical results. 
All ICP analytical results for bismuth, cerium, lanthanum, phosphorus, strontium, sulfur, tin, and zirconium and one result (TCLP leachate of sample 196) for silver were rejected because of lack of initial or continuing calibration verification. The analytical results for silver in six samples (acid digests of samples 146, 147, 175, 176, 179, and 180) were rejected for poor standard or spike recoveries. The silver results of three of those samples and one other sample were also rejected because of interference check samples (acid digests of samples 146, 147, 176, and TCLP leachate of sample 196).

The IC analyses of one sample for fluoride and one for phosphate were rejected for incorrect recovery of a matrix spike (sample 204). The ICP analytical results for two selenium samples were rejected because of poor standard recoveries (samples 175 and 176).

Instrument calibration was the cause of the rejection of the results from two samples for ${ }^{238} \mathrm{Pu}$ (samples 175 and 176), failure of matrix spikes or tracers caused the rejection of the results from one sample for ${ }^{241} \mathrm{Am}$ (sample 176), and from two samples for ${ }^{238} \mathrm{Pu},{ }^{239 / 240} \mathrm{Pu}$ (sample 176 and 204), and preparation blank contamination caused the rejection of one sample for ${ }^{238} \mathrm{Pu},{ }^{239 / 240} \mathrm{Pu}$ (sample 179 ). Total alpha results for six samples were rejected because of a lack of documentation for initial calibration and matrix spikes (samples 93-1807 through 93-1812).

In summary, the vast majority of the QC results were within the boundaries specified in the applicable documents. Other than for the "rejected" data, the discrepancies mentioned here and footnoted in the data summary tables should not impact either the validity or the use of the data. In addition, upon examination of the plutonium and total alpha results, the rejected data appear to be consistent with other non-rejected data.

\section{B3.3 DATA CONSISTENCY CHECKS}

Comparisons of different analytical methods can help to assess the consistency and quality of the data. Several comparisons were possible with the data set provided by the two core samples, including a comparison of phosphorous as analyzed by ICP with phosphate as analyzed by IC, a comparison of weight percent water by TGA with the weight percent water by gravimetry, and comparisons of the total alpha and beta activities with the sum of the alpha- and beta-emitting radionuclides. In addition, mass and charge balances were calculated to help assess the overall data consistency.

\section{B3.3.1 Comparison of Results from Different Analytical Methods}

The following data consistency checks compare the results from two different analytical methods. Agreement between the two methods strengthens the credibility of both results, whereas poor agreement may bring the reliability of the data into question. All analytical mean results were taken from tables in Section B2.0. 
The analytical phosphorus mean result as determined by ICP on the water digested sample was $6,410 \mu \mathrm{g} / \mathrm{g}$, which converts to $19,600 \mu \mathrm{g} / \mathrm{g}$ of phosphate. This compares well with the IC phosphate mean result of $17,800 \mu \mathrm{g} / \mathrm{g}$. The ratio between these two phosphate results was 0.91 . The analytical phosphorus mean result as determined by ICP on the fusion digested sample was $24,700 \mu \mathrm{g} / \mathrm{g}$, which converts to $75,600 \mu \mathrm{g} / \mathrm{g}$ of phosphate. Assuming the analysis was representative of the true concentrations of phosphorus, it is possible that much of the phosphate is water insoluble. The concentration of the phosphate in the drainable liquid sample was $25,000 \mu \mathrm{g} / \mathrm{mL}(22,700 \mu \mathrm{g} / \mathrm{g})$, which accounts for approximately half of the total equivalent phosphate.

The analytical sulfur mean result as determined by ICP on the acid digestion was $1,280 \mu \mathrm{g} / \mathrm{g}$. This is equivalent to $3,830 \mu \mathrm{g} / \mathrm{g}$ sulfate. The sulfate results as measured by IC was $3,900 \mu \mathrm{g} / \mathrm{g}$. The ratio of equivalent sulfate to sulfate was 0.98 , a very close agreement. This is an indication that much if not all of the sulfate is water soluble.

The mean weight percent water results, as determined by TGA, for cores 45 and 46 composites were $67.1,69.55,64.15$, and 69.55 percent respectively. This compared well with the gravimetric results for the same samples of $70.35,70.3,70.5$, and 70.85 percent, respectively. An informal examination of the segment data for percent water by TGA and gravimetry reveal a similar agreement.

Total alpha and total beta activities can be compared to the sums of the activities of the alpha and beta emitters. The sludge mean gross alpha activity was $0.109 \mu \mathrm{Ci} / \mathrm{g}$. The sum of the activities of ${ }^{241} \mathrm{Am}$ and ${ }^{239 / 240} \mathrm{Pu}$ was $0.157 \mu \mathrm{Ci} / \mathrm{g}$. The ratio of gross alpha activity to the sum of the activities of the alpha emitters was 0.69 . Total beta activity was $7.59 \mu \mathrm{Ci} / \mathrm{g}$. The sum of the activities of the beta emitters $\left({ }^{90} \mathrm{Sr}\right.$ and $\left.{ }^{137} \mathrm{Cs}\right)$ was $7.77 \mu \mathrm{Ci} / \mathrm{g}$. The ratio of total beta to the sum of the activities of the beta emitters was 0.98 . The activity of ${ }^{90} \mathrm{Sr}$ was multiplied by 2 to account for the activity of ${ }^{90} \mathrm{Y}$, which exists in secular equilibrium with ${ }^{90} \mathrm{Sr}$ and would have been counted in the total beta measurement and not counted in the ${ }^{90} \mathrm{Sr}$ measurement. The ${ }^{90} \mathrm{Sr}$ and ${ }^{137} \mathrm{Cs}$ results were multiplied by 1.42 and 1.51 , respectively, to account for detector efficiencies that were calibrated to ${ }^{60} \mathrm{Co}$. These results are summarized in Tables B3-1 and B3-2.

Table B3-1. Total Alpha Comparison.

\begin{tabular}{|c|c|}
\hline Anstiglo & 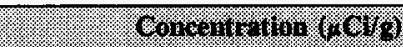 \\
\hline${ }^{239 / 240} \mathrm{Pu}$ & 0.140 \\
\hline${ }^{241} \mathrm{Am}$ & 0.0173 \\
\hline Sum of alpha emitters & 0.1573 \\
\hline Gross alpha result & 0.109 \\
\hline
\end{tabular}


Table B3-2. Total Beta Comparison.

\begin{tabular}{|c|c|}
\hline 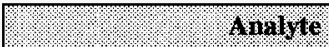 & 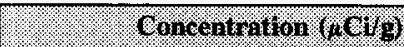 \\
\hline${ }^{90} \mathrm{Sr}$ & 2.63 \\
\hline${ }^{137} \mathrm{Cs}$ & 0.199 \\
\hline Sum of beta emitters ${ }^{1}$ & 7.77 \\
\hline Gross beta result & 7.59 \\
\hline
\end{tabular}

Note:

${ }^{1}$ Calculated using the equation: $1.42 \times 2 \times{ }^{90} \mathrm{Sr}+1.51 \times{ }^{137} \mathrm{Cs}$. The coefficients 1.42 and 1.51 account for the detector efficiencies calibrated to ${ }^{60} \mathrm{Co}$. Factor of 2 accounts for the activity of ${ }^{\infty 0} \mathrm{Y}$ which exists in secular equilibrium with ${ }^{\text {N }} \mathrm{Sr}$.

\section{B3.3.2 Mass and Charge Balance}

The principal objective in performing a mass and charge balance is to determine if the measurements were self-consistent. In calculating the balances, the metals and anions listed in Table B3-6 that were detected at a level greater than $1,000 \mu \mathrm{g} / \mathrm{g}$ were considered. With the exception of sodium, all analytes listed in Table B3-3 are assumed to exist as hydroxide, oxide, or hydroxide precipitates. All positive charge was attributed to the sodium ion.

As discussed in Section B3.3.1, a large discrepancy exists between the mean concentration of equivalent phosphate as derived from the ICP phosphorus mean and the mean concentration of phosphate as measured by IC. It is assumed that some of the extra phosphate exists as insoluble precipitates of sodium, bismuth and iron. The soluble phosphate is listed in Table B3-4 as 'excess phosphate.' The concentrations of the cationic and anionic species in Tables B3-4 and B3-5, and the percent water, were ultimately used to calculate the mass balance.

The mass balance was calculated from the formula below. The factor 0.0001 is the conversion factor from $\mu \mathrm{g} / \mathrm{g}$ to weight percent.

Mass balance $=\%$ water $+0.0001 \times\{$ total analyte concentration $\}$

$$
\begin{aligned}
= & \% \text { water }+0.0001 \times\left\{\left[\mathrm{Al}(\mathrm{OH})_{3}\right]+\left[\mathrm{BiPO}_{4}\right]+[\mathrm{CaO}]+\left[\mathrm{FePO}_{4}\right]+\left[\mathrm{SiO}_{2}\right]\right. \\
& \left.+\left[\mathrm{Na}_{3} \mathrm{PO}_{4}\right]+\left[\mathrm{Na}^{+}\right]+\left[\mathrm{F}^{-}\right]+\left[\mathrm{NO}_{3}{ }^{-}\right]+\left[\mathrm{NO}_{2}{ }^{-}\right]+\left[\mathrm{PO}_{4}{ }^{3-}\right]+\left[\mathrm{SO}_{4}{ }^{2-}\right]\right\}
\end{aligned}
$$


The total of the analyte concentrations calculated from the above equation is $1,010,000 \mu \mathrm{g} / \mathrm{g}$. The mean weight percent water obtained from thermogravimetric analysis reported in Table B3-6 is 70.5 percent, or $705,000 \mu \mathrm{g} / \mathrm{g}$. The mass balance resulting from adding the percent water to the total analyte concentration is 98.7 percent (Table B3-5).

The following equations demonstrate the derivation of total cations and total anions. The charge balance is the ratio of these two values. To derive the results as shown in the equations, all concentrations must be expressed in $\mu \mathrm{g} / \mathrm{g}$.

Total cations $\mu \mathrm{eq} / \mathrm{g}=\left[\mathrm{Na}^{+}\right] / 23.0=2,013 \mu \mathrm{eq} / \mathrm{g}$

Total anions $\mu \mathrm{eq} / \mathrm{g}=\left[\mathrm{F}^{-}\right] / 19.0+\left[\mathrm{NO}_{3}{ }^{-}\right] / 62.0+\left[\mathrm{NO}_{2}{ }^{-}\right] / 46.0+\left[\mathrm{PO}_{4}{ }^{3-}\right] / 31.7+$ $\left[\mathrm{SO}_{4}^{2-}\right] / 48.1=2,121 \mu \mathrm{eq} / \mathrm{g}$.

The charge balance obtained by dividing the sum of the positive charge by the sum of the negative charge was 0.95 .

In summary, the above calculations yield reasonable results for the charge balance and the mass balance. The results for the mass balance were close to 100 percent.

Table B3-3. Cation Mass and Charge Data.

\begin{tabular}{|c|c|c|c|c|}
\hline 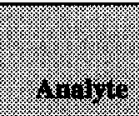 & 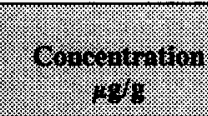 & 4. & 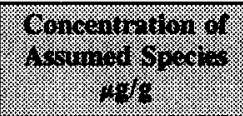 & (6) \\
\hline Aluminum & 16,200 & $\mathrm{Al}(\mathrm{OH})_{3}$ & 46,800 & 0 \\
\hline Bismuth & 18,900 & $\mathrm{BiPO}_{4}$ & 27,500 & 0 \\
\hline Calcium & 1,450 & $\mathrm{CaO}$ & 2,030 & 0 \\
\hline Iron & 9,020 & $\mathrm{FePO}_{4}$ & 24,300 & 0 \\
\hline Silicon & 6,520 & $\mathrm{SiO}_{2}$ & 14,000 & 0 \\
\hline \multirow[t]{2}{*}{ Sodium } & \multirow[t]{2}{*}{64,500} & $\mathrm{Na}_{3} \mathrm{PO}_{4}$ & 42,800 & 0 \\
\hline & & $\mathrm{Na}^{+}$ & 46,500 & 2,013 \\
\hline \multicolumn{3}{|l|}{ Total } & 189,900 & 2,013 \\
\hline
\end{tabular}


Table B3-4. Anion Mass and Charge Data.

\begin{tabular}{|c|c|c|c|c|}
\hline Annory & 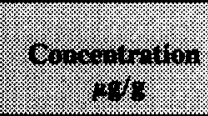 & Spinged & 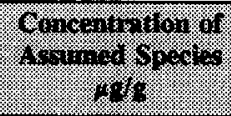 & marros \\
\hline Fluoride & 8,570 & $\mathrm{~F}^{-}$ & 8,570 & 451 \\
\hline Nitrate & 58,000 & $\mathrm{NO}_{3}^{-}$ & 58,000 & 935 \\
\hline Nitrite & 4,240 & $\mathrm{NO}_{2}^{-}$ & 4,240 & 92 \\
\hline $\begin{array}{l}\text { Excess } \\
\text { Phosphate }\end{array}$ & 17,800 & $\mathrm{PO}_{4}{ }^{3-}$ & 17,800 & 562 \\
\hline Sulfate & 3,900 & $\mathrm{SO}_{4}{ }^{2-}$ & 3,900 & 81 \\
\hline \multicolumn{3}{|l|}{ Total } & 92,500 & 2,121 \\
\hline
\end{tabular}

Table B3-5. Mass Balance Totals.

\begin{tabular}{|c|c|c|}
\hline (1) & Conceifrofono & (6) \\
\hline Cation total from Table B3-3 & 189,900 & 2,013 \\
\hline Anion total from Table B3-4 & 92,500 & $-2,121$ \\
\hline Weight percent water & 705,000 & --- \\
\hline Mass balance total & 987,000 & -- \\
\hline Charge balance total & -- & -108 \\
\hline
\end{tabular}

\section{B3.4 CALCULATION OF ANALYTICAL BASED MEANS AND INVENTORY}

The statistics in this section were calculated using analytical data from the most recent core sampling event of tank 241-T-104. Analysis of variance (ANOVA) techniques were used to estimate the mean, and calculate confidence limits on the mean, for each analyte that had all results above the detection limit.

The results given below are ANOVA estimates based on the data from cores 45 and 46 of tank 241-T-104. In the laboratory, two core composite samples were formed from homogenized segment samples. For analytes having all values above the detection limit, an estimate of the mean concentration and a confidence interval on the mean concentration were 
calculated. The estimates are given in Table B3-6. Some analytes had a lower confidence limit less than zero. Because an actual concentration of less than zero is not possible, this lower limit was reported as zero whenever this occurred.

Table B3-6. Tank Concentration From Composite Samples. (4 Sheets)

\begin{tabular}{|c|c|c|c|c|c|}
\hline 1318\% & 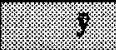 & . & \%: & $4 \% \%$ \% & $65 \%$ \\
\hline W1, Y W & $4 \%$ & $\sqrt{10} \%$ & & 4 & $x_{1}$ \\
\hline ICP.a.Al & 16,200 & $1.41 \mathrm{E}+06$ & 1 & 1,150 & 31,300 \\
\hline ICP.a.B & 15.6 & 2.32 & 1 & 0 & 35.0 \\
\hline ICP.a.Ba & 7.64 & 0.0756 & 1 & 4.15 & 11.1 \\
\hline ICP.a.Bi & 18,900 & 1.22E+05 & 1 & 14,400 & 23,300 \\
\hline ICP.a.Ca & 262 & 1380 & 1 & 0 & 734 \\
\hline ICP.a.Cd & 1.69 & 6,380 & 1 & 0.678 & 2.71 \\
\hline ICP.a.Ce & 194 & 92.6 & 1 & 71.8 & 316 \\
\hline ICP.a.Cr & 901 & 863 & 1 & 527 & 1,270 \\
\hline ICP.a.Cu & 12.5 & 0.13 & 1 & 7.86 & 17.0 \\
\hline ICP.a.Fe & 9,020 & 76,300 & 1 & 5,510 & 12,500 \\
\hline ICP.a.K & 89.0 & 2.85 & 1 & 67.6 & 110 \\
\hline ICP.a.Mg & 103 & 158 & 1 & 53.1 & 154 \\
\hline ICP.a.Mn & 30.6 & 0.413 & 1 & 22.4 & 38.8 \\
\hline ICP.a.Na & 64,500 & $5.18 \mathrm{E}+06$ & 1 & 35,600 & 93,400 \\
\hline ICP.a.Ni & 11.3 & 3.77 & 1 & 0 & 36.0 \\
\hline ICP.a.P & 24,000 & $2.76 \mathrm{E}+05$ & 1 & 17,300 & 30,700 \\
\hline ICP.a.Pb & 49.8 & 82.6 & 1 & 0 & 165 \\
\hline ICP.a.S & 1,280 & 543 & 1 & 980 & 1,570 \\
\hline ICP.a.Si & 1,020 & 21,300 & 1 & 0 & 2,870 \\
\hline ICP.a.Sn & 11.6 & 1.10 & 1 & 0 & 24.9 \\
\hline ICP.a.Sr & 96.8 & 26.0 & 1 & 32.0 & 162 \\
\hline ICP.a.Ti & 4.56 & 0.067 & 1 & 1.27 & 7.85 \\
\hline
\end{tabular}


HNF-SD-WM-ER-372 Rev. 1

Table B3-6. Tank Concentration From Composite Samples. (4 Sheets)

\begin{tabular}{|c|c|c|c|c|c|}
\hline 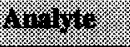 & 1 & $\%$ & (1) & rys & 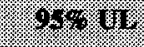 \\
\hline ICP.a. $\mathrm{Zn}$ & 23.5 & 2.00 & 1 & 5.55 & 41.5 \\
\hline ICP.a.Zr & 67.5 & 463 & 1 & 0 & 341 \\
\hline ICP.f.Al & 15,600 & $3.56 \mathrm{E}+06$ & 1 & 0 & 39,600 \\
\hline ICP.f.Ba & 8.58 & 0.0434 & 1 & 5.93 & 11.2 \\
\hline ICP.f.Bi & 17,400 & $1.21 \mathrm{E}+06$ & 1 & 3,370 & 31,300 \\
\hline ICP.f.Ca & 1,450 & $5.89 E+05$ & 1 & 0 & 11,200 \\
\hline ICP.f.Ce & 160 & 195 & 1 & 0 & 337 \\
\hline ICP.f.Cr & 867 & 365 & 1 & 624 & 1,110 \\
\hline ICP.f.Cu & 51.0 & 174 & 1 & 0 & 218 \\
\hline ICP.f.Fe & 8,840 & $3.80 \mathrm{E}+05$ & 1 & 1,010 & 16,700 \\
\hline ICP.f.Mg & 140 & 436 & 1 & 0 & 406 \\
\hline ICP.f.Mn & 61.8 & 6.42 & 1 & 29.6 & 94.0 \\
\hline ICP.f.Na & 62,100 & $1.63 \mathrm{E}+06$ & 1 & 45,800 & 78,300 \\
\hline ICP.f.P & 24,700 & $4.57 \mathrm{E}+06$ & 1 & 0 & 51,800 \\
\hline ICP.f.S & 1,270 & 977 & 1 & 869 & 1,660 \\
\hline ICP.f.Si & 6,520 & 33,300 & 1 & 4,200 & 8,830 \\
\hline ICP.f.Sr & 99.1 & 13.4 & 1 & 52.6 & 146 \\
\hline ICP.f.Ti & 9.67 & 2.07 & 1 & 0 & 280 \\
\hline ICP.f.Zn & 137 & 2310 & 1 & 0 & 747 \\
\hline ICP.f. $\mathrm{Zr}$ & 37.5 & 8.18 & 1 & 1.12 & 73.8 \\
\hline ICP.w.Al & 158 & 163 & 1 & 0 & 320 \\
\hline ICP.w.B & 11.5 & 0.391 & 1 & 3.53 & 194 \\
\hline ICP.w.Bi & 168 & 195 & 1 & 0 & 346 \\
\hline ICP.w.Ca & 171 & 141 & 1 & 20.5 & 322 \\
\hline ICP.w. Cr & 144 & 21.4 & 1 & 85.1 & 203 \\
\hline ICP.w.Fe & 80.8 & 33.5 & 1 & 7.22 & 154 \\
\hline
\end{tabular}


HNF-SD-WM-ER-372 Rev. 1

Table B3-6. Tank Concentration From Composite Samples. (4 Sheets)

\begin{tabular}{|c|c|c|c|c|c|}
\hline 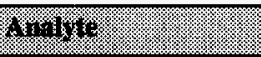 & 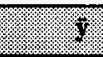 & (3.6. & 壮: & $4 \%$ & $9 \%$ \\
\hline ICP.w.K & 35.9 & 1.53 & 1 & 20.2 & 51.6 \\
\hline ICP.w.Mg & 6.06 & 1.76 & 1 & 0 & 22.9 \\
\hline ICP.w.Na & 46,500 & $1.03 \mathrm{E}+06$ & 1 & 33,600 & 59,400 \\
\hline ICP.w.P & 6,410 & 45,700 & 1 & 3,690 & 9,120 \\
\hline ICP.w.S & 1,280 & 319 & 1 & 1,060 & 1,510 \\
\hline ICP.w.Si & 167 & 17.3 & 1 & 11.4 & 220 \\
\hline ICP.w.Sr & 1.17 & 0.0268 & 1 & 0 & 3.25 \\
\hline ICP.w.Zr & 2.45 & 0.0216 & 1 & 0.586 & 4.32 \\
\hline $4 \%$ & 68 & $\%$ & 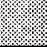 & W & \%) \\
\hline IC.w.Cl & 670 & 105 & 1 & 539 & 800 \\
\hline IC.w.F & 8,570 & 26,900 & 1 & 6,490 & 10,700 \\
\hline IC.w. $\mathrm{NO}_{2}$ & 4,080 & 652 & 1 & 3,760 & 4,410 \\
\hline Spec.w.NO & 4,240 & 2,170 & 1 & 3,650 & 4,830 \\
\hline IC.w. $\mathrm{NO}_{3}$ & 58,000 & $5.67 \mathrm{E}+05$ & 1 & 48,500 & 67,600 \\
\hline IC.W. $\mathrm{PO}_{4}$ & 17,800 & $7.44 \mathrm{E}+05$ & 1 & 6,850 & 28,800 \\
\hline IC.w. $\mathrm{SO}_{4}$ & 3,900 & 971 & 1 & 3,500 & 42,900 \\
\hline 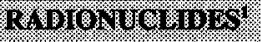 & $101 \%$ & 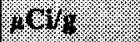 & & $101 \%$ & 40 \\
\hline GEA.f. ${ }^{241} \mathrm{Am}$ & 0.0142 & $8.10 \mathrm{E}-07$ & 1 & 0.00274 & 0.0256 \\
\hline GEA.f. ${ }^{137} \mathrm{Cs}$ & 0.199 & $3.16 \mathrm{E}-05$ & 1 & 0.128 & 0.271 \\
\hline GEA.f. ${ }^{155} \mathrm{Eu}$ & 0.00342 & $4.69 \mathrm{E}-08$ & 1 & $6.68 \mathrm{E}-04$ & 0.00617 \\
\hline f.Gross.alpha & 0.109 & $2.26 \mathrm{E}-05$ & 1 & 0.0486 & 0.169 \\
\hline f. Gross. beta & 7.59 & 0.683 & 1 & 0 & 18.1 \\
\hline${ }^{241} \mathrm{Am}$ & 0.0173 & $7.38 \mathrm{E}-07$ & 1 & 0.00636 & 0.0282 \\
\hline${ }^{239 / 240} \mathrm{Pu}$ & 0.140 & 0.00650 & 1 & 0.057 & 0.222 \\
\hline${ }^{239} \mathrm{Pu}$ & $96.8 \%$ & $0.0190 \%$ & 1 & $95.0 \%$ & $98.5 \%$ \\
\hline${ }^{240} \mathrm{Pu}$ & $3.19 \%$ & $0.0168 \%$ & 1 & $1.55 \%$ & $4.84 \%$ \\
\hline
\end{tabular}


Table B3-6. Tank Concentration From Composite Samples. (4 Sheets)

\begin{tabular}{|c|c|c|c|c|c|}
\hline Mrow & Y & (1) & 10 & 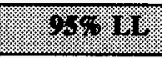 & $9 \%$ \\
\hline${ }^{241} \mathrm{Pu}$ & $0.0399 \%$ & $8.33 \mathrm{E}-05 \%$ & 1 & $0 \%$ & $0.156 \%$ \\
\hline${ }^{90} \mathrm{Sr}$ & 2.63 & 0.0570 & 1 & 0 & 5.66 \\
\hline $\mathbf{U}$ & $897 \mu \mathrm{g} / \mathrm{g}$ & 394 & 1 & 645 & 1,150 \\
\hline${ }^{234} \mathrm{U}$ & $0.00725 \%$ & $1.56 \mathrm{E}-06 \%$ & 1 & 0 & $0.0231 \%$ \\
\hline${ }^{235} \mathrm{U}$ & $0.674 \%$ & $5.93 \mathrm{E}-05 \%$ & 1 & $0.577 \%$ & $0.772 \%$ \\
\hline${ }^{236} \mathrm{U}$ & $0.00675 \%$ & $6.88 \mathrm{E}-07 \%$ & 1 & $0 \%$ & $0.0173 \%$ \\
\hline${ }^{238} \mathrm{U}$ & $99.3 \%$ & $7.42 \mathrm{E}-05 \%$ & 1 & $99.2 \%$ & $99.4 \%$ \\
\hline \multicolumn{6}{|l|}{ 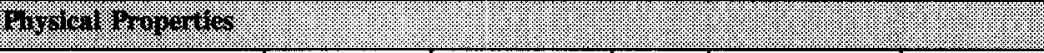 } \\
\hline Percent.H20 & 70.5 & 0.0400 & 1 & 68.0 & 73.1 \\
\hline
\end{tabular}

Notes: LL $=$ lower limit

UL $\quad=\quad$ upper limit

df $=$ degrees of freedom

f $\quad=$ fusion digestion

a $\quad=$ acid digestion

$w \quad=$ water digestion

${ }^{1} \mathrm{Pu}$ isotope values are given in weight percent of total $\mathrm{Pu}, \mathrm{U}$ isotope values are given in weight percent of total $\mathrm{U}$.

The statistical model that describes the structure of the core composite data is

$$
\begin{gathered}
y_{i j k}=\mu+S_{i}+C_{i j}+A_{i j k}, \\
i=1, \ldots a, j=1, \ldots b_{i}, k=1, \ldots n_{i j},
\end{gathered}
$$

where

$$
\begin{aligned}
& \mathrm{y}_{\mathrm{ijk}}=\text { laboratory results from the } \mathrm{k}^{\text {th }} \text { duplicate of the } \mathrm{j}^{\text {th }} \text { composite of the } \mathrm{i}^{\text {th }} \\
& \text { core from the tank, } \\
& \mu \quad=\quad \text { the grand mean of all the data, } \\
& S_{i}=\text { the effect of the } i^{\text {th }} \text { core (spatial effect), }
\end{aligned}
$$


$\mathrm{C}_{\mathrm{ij}}=$ the effect of the $\mathrm{j}^{\text {th }}$ composite sample from the $\mathrm{i}^{\text {th }}$ core,

$\mathrm{A}_{\mathrm{ijk}}=$ the analytical error associated with the $\mathrm{k}^{\text {th }}$ duplicate in the $\mathrm{j}^{\mathrm{th}}$ composite from the $i^{\text {th }}$ core,

a $=$ the number of cores,

$b_{i}=$ the number of composite samples in the $i^{\text {th }}$ core, and

$n_{i j}=$ the number of analytical results from the $j^{\text {th }}$ composite sample in the $i^{\text {th }}$ core.

For cores 45 and 46 there are two core composite samples (i.e., $b_{i}=2$ ).

The variables $S_{i}$ and $C_{i j}$ are random effects. It is assumed that $S_{i}, C_{i j}$, and $A_{i j k}$ are each distributed normally with mean zero and variances of $\sigma^{2}(\mathrm{~S}), \sigma^{2}(\mathrm{C})$, and $\sigma^{2}(\mathrm{~A})$, respectively. Estimates of $\sigma^{2}(\mathrm{~S}), \sigma^{2}(\mathrm{C})$, and $\sigma^{2}(\mathrm{~A})$ were obtained using Restricted Maximum Likelihood Estimation (REML). This method applied to variance component estimation is described by Harville (1977). The REML estimates were obtained using the statistics program S-Plus ${ }^{1}$ (Statistical Sciences 1993).

The mean concentration of each analyte of interest in the tank was calculated using the following equation:

where

$$
\begin{gathered}
\bar{y}=\frac{1}{a} \sum_{i=1}^{a} \bar{y}_{i++}=\frac{1}{a} \sum_{i=1}^{a} \frac{\sum_{j=1}^{b_{1}} \sum_{k=1}^{n_{k}} y_{i j k}}{n_{i+}}=\frac{1}{a} \sum_{i=1}^{a} \frac{\sum_{j=1}^{b_{i}} \sum_{k=1}^{n_{i}}\left(\mu+S_{i}+C_{i j}+A_{i j k}\right)}{n_{i+}} . \\
\bar{y}_{i++}=\frac{\sum_{j=1}^{b_{i}} \sum_{k=1}^{n_{i}} y_{i j k}}{n_{i+}} \text { and } n_{i++}=\sum_{j=1}^{b_{i}} n_{i j} \text {. }
\end{gathered}
$$

This mean gives the results from each core the same weight regardless of the unbalance that may exist for a particular analyte.

\footnotetext{
${ }^{1}$ Trademark of Statistical Sciences, Seattle, Washington.
} 
The variance of $\bar{y}$ is

$$
\mathrm{V}(\overline{\mathrm{y}})=\mathrm{C}_{1} \sigma^{2}(\mathrm{~S})+\mathrm{C}_{2} \sigma^{2}(\mathrm{C})+\mathrm{C}_{3} \sigma^{2}(\mathrm{~A})
$$

where

$$
C_{1}=\frac{1}{a}, \quad C_{2}=\frac{1}{a^{2}} \sum_{i=1}^{a}\left[\frac{1}{n_{i+}}\right]^{2}\left[\sum_{j=1}^{b_{1}} n_{i j}^{2}\right], \quad C_{3}=\frac{1}{a^{2}} \sum_{i=1}^{a}\left[\frac{1}{n_{i+}}\right] .
$$

Using $\hat{\sigma}^{2}(\mathrm{~S}), \hat{\sigma}^{2}(\mathrm{C})$, and $\hat{\sigma}^{2}(\mathrm{~A})$ (REML variance component estimates), an estimated variance of $\bar{y}$ is

$$
\hat{\sigma}^{2}(\overline{\mathrm{y}})=\mathrm{C}_{1} \hat{\sigma}^{2}(\mathrm{~S})+\mathrm{C}_{2} \hat{\sigma}^{2}(\mathrm{C})+\mathrm{C}_{3} \hat{\sigma}^{2}(\mathrm{~A}) .
$$

The approximate degrees of freedom used for $\hat{\sigma}^{2}(\bar{y})$ is the number of cores with data minus one.

The lower and upper 95\% limits (95\% LL and 95\% UL respectively) on the mean concentration are

$$
95 \% \mathrm{LL}=\overline{\mathrm{y}}-\mathrm{t}_{.025} \sqrt{\hat{\sigma}^{2}(\overline{\mathrm{y}})} \text { and } 95 \% \mathrm{UL}=\overline{\mathrm{y}}+\mathrm{t}_{.025} \sqrt{\hat{\sigma}^{2}(\overline{\mathrm{y}})}
$$

where $t_{0.025}$ is the 0.025 quantile from a Student's $t$-distribution with one degree of freedom $\left(\mathrm{t}_{0.025}=12.706\right)$ for a one-sided 95 percent confidence interval.

Core recoveries for the two core samples (cores 45 and 46) taken from tank 241-T-104 were very good. The segment recoveries for each core are shown in Table B3-7. For both core samples there was nearly $100 \%$ segment recovery for most segments. Based on waste levels, segment 1 of each core was expected to be a partial segment with, at most, $6.4 \mathrm{~cm}(2.5 \mathrm{in}$.) of sample. Therefore, the expected recovery for segment 1 was only about $13 \%$. Because sample recovery was high, any bias (due to incomplete recovery) in the results given in Table B3-6 should be minimal.

Table B3-7. Tank 241-T-104 Core Recoveries.

\begin{tabular}{|c|c|c|c|c|c|c|c|c|c|}
\hline Core & \multicolumn{10}{|c|}{ Segnent Number } & & \\
\hline & 1 & 2 & 3 & 4 & 5 & 6 & 7 & 8 & 9 \\
\hline 45 & $5 \%$ & $90 \%$ & $100 \%$ & $75 \%$ & $95 \%$ & $75 \%$ & $94 \%$ & $100 \%$ & $100 \%$. \\
\hline 46 & $0 \%$ & $100 \%$ & $60 \%$ & $100 \%$ & $100 \%$ & $65 \%$ & $98 \%$ & $90 \%$ & $100 \%$ \\
\hline
\end{tabular}


Sample-based inventory estimates can be calculated by multiplying the means in Table B3-6 by an estimate of the total sludge mass. Some analytes had data from fusion, acid, and water digestions. In such cases, the fusion digestion results were generally used to calculate the inventory because fusion digestion usually results in more complete dissolution than acid digestion. Acid digestion results should be used for potassium because the fusion digestion was performed by fusing the sample with potassium hydroxide. Acid digestion results should also be used for boron, cadmium, lead, and tin because the higher dilutions of the fusion digestion resulted in high detection limits for these analytes.

The volume of the sludge in tank $241-\mathrm{T}-104$ at the time of sampling was $1,673 \mathrm{~kL}$ $(442 \mathrm{kgal})$. The samples that were recovered had density measurements that ranged from $1.24 \mathrm{~g} / \mathrm{mL}$ to $1.42 \mathrm{~g} / \mathrm{mL}$ with an average of $1.285 \mathrm{~g} / \mathrm{mL}$. Using the average density and the estimated sludge volume, an estimate of the total mass of sludge is $2.15 \times 10^{6} \mathrm{~kg}$. The inventory values (with the exception of the $\mathrm{Pu}$ and $\mathrm{U}$ isotopic results) can be calculated by multiplying the mean concentration values in Table B3-6 by this number. For the Pu and U isotopic results given as percent of total $\mathrm{Pu}$ or $\mathrm{U}$, the percentage results need to be ratioed to the ${ }^{239 / 240} \mathrm{Pu}$ or total $\mathrm{U}$ results to calculate concentration as $\mu \mathrm{Ci} / \mathrm{g}$ or $\mu \mathrm{g} / \mathrm{g}$ before multiplying by the mass of the sludge.

Since the time of core sampling, saltwell liquid has been removed from the tank. Because solids have not been removed from the tank and because the core composite used to generate the concentrations in Table B3-6 did not include drainable liquids in the core samples, the present tank sludge inventory should be close to that calculated in the manner described in the previous paragraph. To provide a lower bound on the tank inventory, one can assume that the saltwell liquid pumped has the same composition as the drainable liquid that was analyzed, calculate the inventory of waste pumped from the tank (by multiplying the drainable liquid concentrations by the $317 \mathrm{~kL}$ pumped), and subtract this amount from the initial tank inventory. 


\section{B4.0 APPENDIX B REFERENCES}

DeLorenzo, D. S., J. H. Rutherford, D. J. Smith, D. B. Hiller, K. W. Johnson, 1994, Tank Characterization Reference Guide, WHC-SD-WM-TI-648, Rev. 0A, Westinghouse Hanford Company, Richland, Washington.

Dukelow, G. T., J. W. Hunt, H. Babad, and J. E. Meacham, 1995, Tank Safety Screening Data Quality Objective, WHC-SD-WM-SP-004, Rev. 2, Westinghouse Hanford Company, Richland, Washington.

Harville, D. A., 1977, "Maximum Likelihood Approaches to Variance Component Estimation and to Related Problems," Journal of the American Statistical Association, 72:358, pp. 324-340.

Hill, J. G., W. I. Winters, B. C. Simpson, J. W. Buck, P. J. Chamberlain, and V. L. Hunter, 1991, Waste Characterization Plan for the Hanford Site Single-Shell Tanks, WHC-EP-0210, Rev. 3, Westinghouse Hanford Company, Richland, Washington.

Horton, J. E., 1979, Physical and Chemical Characterization of Tank 104-T, (internal letter 65124-79-017 to D. J. Flesher, November 13), Rockwell Hanford Operations, Richland, Washington.

Jones, T. E., 1993, Pacific Northwest Laboratory Single-Shell Tank Waste Characterization Project (16021) and Single-Shell Tank Safety Analysis Project (19091) Technical Project Plan, Pacific Northwest Laboratory Richland, Washington.

Pool, K. N., 1994, Single-Shell Tank Waste Characterization Tank 241-T-104, Cores 45 and 46, WHC-SD-WM-DP-032, Rev. 0A, Westinghouse Hanford Company, Richland, Washington.

Silvers, K. L., 1991, Sampling and Analysis of Ten Single-Shell Tanks, Statement of Work, WHC-SOW-91-0006, Rev. 1, Westinghouse Hanford Company, Richland, Washington.

Smith, H. E., 1992, Technical Project Plan-Response to WHC-SOW-91-0006 for the 222-S Analytical Laboratory, WHC-SD-CP-TP-070, Rev. 0, Westinghouse Hanford Company, Richland, Washington.

Statistical Sciences, 1993, S-PLUS Reference Manual Version 3.2, StatSci, a division of MathSoft, Inc., Seattle, Washington. 
HNF-SD-WM-ER-372 Rev. 1

WHC, 1996, T-104 Riser Preparation, Work Package WS-95-00291, Westinghouse Hanford Company, Richland, Washington. 
HNF-SD-WM-ER-372 Rev. 1

This page left blank intentionally. 
HNF-SD-WM-ER-372 Rev. 1

\author{
APPENDIX C \\ STATISTICAL ANALYSIS FOR ISSUE RESOLUTION
}

C-1 
HNF-SD-WM-ER-372 Rev. 1

This page intentionally left blank. 


\section{APPENDIX C \\ STATISTICAL ANALYSIS FOR ISSUE RESOLUTION}

In Appendix $\mathrm{C}$, the analyses required for the applicable data quality objective (DQO) reports for tank 241-T-104 are performed. Specifically, statistical and other numerical manipulations required in the DQO reports are performed and documented in this appendix. The analyses required for tank 241-T-104 are documented in the following sections:

- Section C1: Statistical analysis supporting the Safety Screening DQO (Dukelow et al. 1995). Specifically, confidence intervals were needed to support the plutonium (criticality) threshold limit.

- Section C2: References for Appendix C.

\section{C1.0 STATISTICS FOR SAFETY SCREENING DQO}

The safety screening DQO (Dukelow et al. 1995) defines acceptable decision confidence limits in terms of one-sided 95 percent confidence intervals on the mean for each subsample. In this appendix, one-sided confidence limits supporting the safety screening DQO are calculated for tank 241-T-104. All data considered in this section are taken from the final laboratory data package for the 1992 core sampling event for tank 241-T-104 (Pool 1994).

Confidence intervals were computed for each sample number from tank 241-T-104 analytical data. The sample numbers and confidence intervals are provided in Table C1-1.

The upper limit (UL) of a one-sided 95 percent confidence interval for the mean is

$$
\hat{\mu}+t_{(n-1,0.95)} * \sqrt{\frac{\hat{\sigma}^{2}}{n}}
$$

where $\hat{\mu}$ is the arithmetic mean of the data, $n$ is the number of observations, $\hat{\sigma}^{2}$ is the estimate of the variance of the data, and $t_{(n-1,0.95)}$ is a quantile from Student's $t$ distribution with $n-1$ degrees of freedom and 0.95 confidence.

For the tank 241-T-104 data (per sample number), $n$ is two and $t_{(1,0.95)}$ is 6.314 . 
The upper limit of the one-sided 95 percent confidence interval for each sample number based on the total alpha data is listed in Table C1-1. Each confidence interval can be used to make the following statement. If the upper limit is less than $47.7 \mu \mathrm{Ci} / \mathrm{g}$, then one would reject the null hypothesis that the total alpha is greater than or equal to $47.7 \mu \mathrm{Ci} / \mathrm{g}$ at the 0.05 level of significance. The upper limit of $47.7 \mu \mathrm{Ci} / \mathrm{g}$ was calculated from the $1 \mathrm{~g} / \mathrm{L}$ plutonium limit, using a measured density of $1.29 \mathrm{~g} / \mathrm{mL}$ (Pool 1994), and assuming that all the plutonium is ${ }^{239} \mathrm{Pu}$.

Table C1-1. One-Sided 95 Percent Confidence Interval Upper Limits for Total Alpha for Tank 241-T-104.

\begin{tabular}{|c|c|c|c|c|c|}
\hline $\begin{array}{l}\text { Sample. } \\
\text { friminer. }\end{array}$ & Surnple Loeallon & $\begin{array}{l}\text { Somiple: } \\
\text { Portion }\end{array}$ & $6(1010$ & $\frac{1}{6} n$ & $01 .(1.16)$ \\
\hline 175 & \multirow[t]{2}{*}{ Core 45 composite } & WHOLE & 0.102 & $1.00 \mathrm{E}-06$ & 0.108 \\
\hline 176 & & WHOLE & 0.1065 & $2.50 \mathrm{E}-07$ & 0.110 \\
\hline 179 & \multirow[t]{2}{*}{ Core 46 composite } & WHOLE & 0.118 & $9.00 \mathrm{E}-06$ & 0.137 \\
\hline 180 & & WHOLE & 0.1095 & $2.50 \mathrm{E}-07$ & 0.113 \\
\hline
\end{tabular}

Note:

$\mathrm{UL}=$ Upper limit

Confidence intervals were not performed on the differential scanning calorimetry (DSC) data, because no exotherms were detected.

\section{C2.0 APPENDIX C REFERENCES}

Dukelow, G. T., J. W. Hunt, H. Babad, and J. E Meacham, 1995, Tank Safety Screening Data Quality Objective, WHC-SD-WM-SP-004, Rev. 2, Westinghouse Hanford Company, Richland, Washington.

Pool, K. N., 1994, Single-Shell Tank Waste Characterization Tank 241-T-104, Cores 45 and 46, WHC-SD-WM-DP-032, Rev. 0-A, Westinghouse Hanford Company, Richland, Washington. 
HNF-SD-WM-ER-372 Rev. 1

APPENDIX D

EVALUATION TO ESTABLISH BEST-BASIS

INVENTORY FOR TANK 241-T-104 
HNF-SD-WM-ER-372 Rev. 1

This page intentionally left blank.

\section{D-2}




\section{APPENDIX D \\ EVALUATION TO ESTABLISH BEST-BASIS \\ INVENTORY FOR TANK 241-T-104}

An effort is underway to provide waste inventory estimates that will serve as standard characterization source terms for the various waste management activities (Hodgson and LeClair 1996). As part of this effort, an evaluation of available chemical information for tank 241-T-104 was performed, and a best-basis inventory was established. This work, detailed in the following sections, follows the methodology that was established by the standard inventory task.

\section{D1.0 CHEMICAL INFORMATION SOURCES}

The data package for single-shell tank 241-T-104 (Pool 1994) provided characterization results from the most recent core sampling event for this tank; the results are presented in Appendix B. Two core samples were obtained and analyzed. Jensen et al. (1994) summarizes the results from the statistical analysis of data from two core composites. Estimates of the spatial variance, compositing variance, and the spatial variance for the core composite data were provided. Both the analytical and systematic error of the tank 241-T-104 core samples were presented. Mean concentrations and confidence intervals are presented in Appendix B.

Component inventories at the time of sampling were calculated by multiplying the mean concentration of an analyte (presented in Table B3-6) by the density of the waste $(1.29 \mathrm{~g} / \mathrm{mL}$ ) and the volume of the sludge at the time of sampling (1,673 kL [442 kgal]). Sample-based inventories listed in Tables D2-1 and D2-2 are derived from the mean concentrations in Table B3-6 and the Hanford defined waste (HDW) model developed at Los Alamos National Laboratory (Agnew et al. 1996b). The HDW model (Agnew et al. 1996b) provides tank content estimates, in terms of component concentrations and inventories. The HDW model estimated the tank inventory using the total waste volume of $1,684 \mathrm{~kL}$ (445 kgal), consisting of $1,673 \mathrm{~kL}$ (442 kgal) of sludge and $11.4 \mathrm{~kL}$ ( $3 \mathrm{kgal})$ of supernate, reported by Hanlon (1992) at the time of sampling and prior to the start of saltwell pumping. The sampling-based inventory is based upon the sludge volume $(1,673 \mathrm{~kL}$ [442 kgal]) only. The supernatant contributes a small amount to the total tank inventory. 
Table D2-1. Sample- and Historical Tank Content-Based Inventory Estimates for Nonradioactive Components. (2 sheets)

\begin{tabular}{|c|c|c|c|c|c|}
\hline (1) & 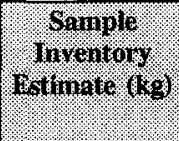 & 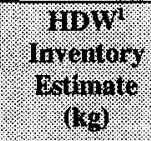 & horate & 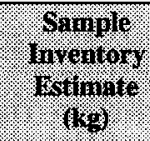 & 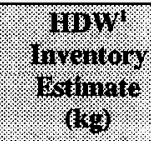 \\
\hline $\mathrm{Al}$ & 33,500 & 31,700 & $\mathrm{Ni}$ & 22,600 & 126 \\
\hline $\mathrm{Ag}$ & NR & NR & $\mathrm{NO}_{2}$ & 8,770 & 17,300 \\
\hline As & NR & NR & $\mathrm{NO}_{3}$ & 125,000 & 41,200 \\
\hline $\mathrm{Ba}$ & 18.4 & NR & $\mathrm{OH}$ & NR & 84,200 \\
\hline $\mathrm{Be}$ & NR & NR & oxalate & NR & 0.0036 \\
\hline $\mathrm{Bi}$ & 37,400 & 20,300 & $\mathrm{~Pb}$ & NR & 0.87 \\
\hline $\mathrm{Ca}$ & 3,120 & 3,900 & $\mathrm{Pd}$ & NR & NR \\
\hline $\mathrm{Ce}$ & 344 & NR & $\mathrm{P}$ as $\mathrm{PO}_{4}$ & 162,000 & 170,000 \\
\hline $\mathrm{Cd}$ & 3.63 & NR & $\mathrm{Pt}$ & NR & NR \\
\hline $\mathrm{Cl}$ & 1,440 & 847 & $\mathrm{Rh}$ & NR & NR \\
\hline $\mathrm{Co}$ & NR & NR & $\mathrm{Ru}$ & NR & NR \\
\hline $\mathrm{Cr}$ & 1,860 & 371 & $\mathrm{Sb}$ & NR & NR \\
\hline $\mathrm{Cr}^{+3}$ & NR & 371 & $\mathrm{Se}$ & NR & NR \\
\hline $\mathrm{Cr}^{+6}$ & NR & NR & $\mathrm{Si}$ & 14,000 & 2,630 \\
\hline $\mathrm{Cs}$ & NR & NR & $\mathrm{SO}_{4}$ & 8,390 & 7,930 \\
\hline $\mathrm{Cu}$ & 110 & NR & $\mathrm{Sr}$ & 213 & 0.0014 \\
\hline $\mathrm{F}$ & $18,400^{3}$ & 5,760 & $\mathrm{Te}$ & NR & NR \\
\hline $\mathrm{Fe}$ & 19,000 & 22,400 & $\mathrm{CO}_{3}$ & NR & 5,970 \\
\hline $\mathrm{FeCN} / \mathrm{CN}$ & NR & NR & $\mathrm{Th}$ & NR & NR \\
\hline formate & NR & NR & $T]$ & NR & NR \\
\hline $\mathrm{Hg}$ & NR & 26.2 & TOC & NR & NR \\
\hline $\mathrm{K}$ & 191 & 205 & $\mathrm{U}_{\text {TOTAL }}$ & 1,930 & 254 \\
\hline $\mathrm{La}$ & NR & 0.0066 & $\mathrm{~V}$ & NR & NR \\
\hline $\mathrm{Mg}$ & 303 & NR & W & NR & NR \\
\hline $\mathrm{Mn}$ & 133 & 0.99 & $\mathrm{Zn}$ & 295 & NR \\
\hline
\end{tabular}


Table D2-1. Sample- and Historical Tank Content-Based Inventory Estimates for Nonradioactive Components. (2 sheets)

\begin{tabular}{|c|c|c|c|c|c|}
\hline : & 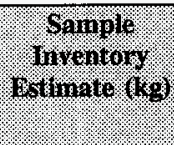 & 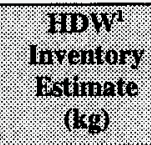 & Ainilitio & 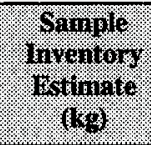 & 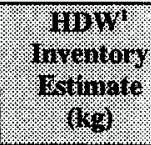 \\
\hline Mo & NR & NR & $\mathrm{Zr}$ & 80.6 & 1,280 \\
\hline $\mathrm{Na}$ & 134,000 & 159,000 & $\mathrm{H}_{2} \mathrm{O}(\mathrm{wt} \%)$ & 70.5 & 72.7 \\
\hline $\mathrm{Nd}$ & NR & NR & \multirow[t]{2}{*}{ density $(\mathrm{kg} / \mathrm{L})$} & \multirow[t]{2}{*}{1.29} & \multirow[t]{2}{*}{1.25} \\
\hline $\mathrm{NH}_{3}$ & NR & 15.5 & & & \\
\hline
\end{tabular}

Notes:

$\begin{array}{lll}\text { HDW } & = & \text { Hanford Defined Waste } \\ \text { NR } & = & \text { Not reported }\end{array}$

'Agnew et al. (1996b)

Table D2-2. Sample- and Historical Tank Content-Based Inventory Estimates for Radioactive Components.

\begin{tabular}{|c|c|c|c|c|c|}
\hline Analyte & 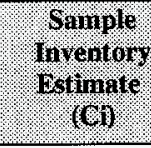 & 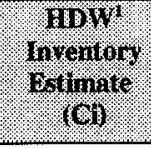 & Anafite & 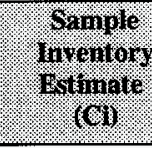 & 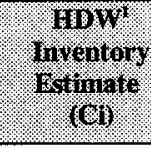 \\
\hline${ }^{14} \mathrm{C}$ & NR & NR & ${ }^{237} \mathrm{~Np}$ & NR & NR \\
\hline${ }^{90} \mathrm{Sr}$ & 5,650 & 930 & ${ }^{239 / 240} \mathrm{Pu}$ & 300 & 27 \\
\hline${ }^{99} \mathrm{Tc}$ & NR & NR & ${ }^{241} \mathrm{Am}$ & 37.2 & NR \\
\hline${ }^{129} \mathrm{I}$ & NR & NR & Total $\alpha$ & 234 & NR \\
\hline${ }^{137} \mathrm{Cs}$ & 428 & 38,100 & Total $\beta$ & 16,300 & NR \\
\hline${ }^{155} \mathrm{Eu}$ & 7.35 & NR & & & \\
\hline
\end{tabular}

Notes:

$\begin{array}{lll}\text { HDW } & = & \text { Hanford Defined Waste } \\ \text { NR } & = & \text { Not reported }\end{array}$

Agnew et al. (1996b) 
Since the time of core sampling, saltwell liquid has been removed from the tank. Because solids have not been removed from the tank and because the core composite used to generate the concentrations in Table B3-6 did not include drainable liquids recovered from the core samples, the present tank sludge inventory should be close to that calculated in the manner described above. To provide a lower bound on the tank inventory, one could assume that the saltwell liquid pumped has the same composition as the drainable liquid that was analyzed, calculate the inventory of waste pumped from the tank (by multiplying the drainable liquid concentrations by the $317 \mathrm{~kL}(83.8 \mathrm{kgal})$ pumped as of September 30,1996$)$, and subtracting this amount from the initial tank inventory.

\section{D2.0 COMPARISON OF COMPONENT INVENTORY VALUES}

Sample-based inventories derived from analytical concentration data and HDW model inventories are compared in Tables D2-1 and D2-2. The sludge volume used to generate the sample-based inventory is $1,673 \mathrm{~kL}$ (442 kgal) (Hanlon 1992). The HDW model included the $11.4 \mathrm{~kL}$ ( $3 \mathrm{kgal})$ of supernate present prior to saltwell pumping, for a total tank waste volume of $1,684 \mathrm{~kL}$ (445 kgal) (Hanlon 1992). The mean sludge density, which includes interstitial liquid, used to calculate the sample-based component inventories is $1.29 \mathrm{~g} / \mathrm{mL}$ (the mean of the values in Table B2-4). The means from the ICP fusion digestion analyses were used for aluminum, beryllium, bismuth, cerium, chromium, iron, phosphorus, silicon, magnesium, manganese, and sodium. The ICP acid digestion means were used for cadmium, nickel, and potassium and the IC water digestion means were used for chloride, fluoride, nitrite, and nitrate. The HDW model density for the sludge and total waste is estimated to be $1.25 \mathrm{~g} / \mathrm{mL}$ (approximately 3 percent less than the measured density). Note the significant differences between the sample-based and HDW model inventories for several of the bulk components, e.g., bismuth, fluoride, nitrate, nitrite, uranium, zirconium, and silicon.

\section{D3.0 REVIEW AND EVALUATION OF COMPONENT INVENTORIES}

The following evaluation of tank contents is performed to identify potential errors and/or missing information that would influence the sample-based and HDW model component inventories.

\section{D3.1 PROCESS KNOWLEDGE}

Tank 241-T-104 began receiving first cycle decontamination (1C) waste in March 1946 and was filled in August 1946. There was no cascading at this time. Nearly $3,400 \mathrm{~kL}$ ( $900 \mathrm{kgal})$ of $1 \mathrm{C}$ waste was received by tank $241-\mathrm{T}-104$ in a series of additions in 1948 and 
1949 (Jungfleisch 1984). The tank was already full, so this waste all cascaded to tanks 241-T-105 and 241-T-106. Since it was the primary tank in the cascade, most of the solids in the 1C waste settled in tank 241-T-104. When the supernate was removed from the tanks in the cascade and sent to cribs in 1953, tank $241-\mathrm{T}-104$ held $1,410 \mathrm{~kL}$ (372 kgal) of solids (Anderson 1990). A discrepancy in the historical records is found here. Up to this time, $5,360 \mathrm{~kL}(1,440 \mathrm{kgal}$ ) of waste additions (all pre-1951 1C) to tank 241-T-104 are documented (Jungfleisch 1984). For $5,360 \mathrm{~kL}$ of waste to deposit $1,410 \mathrm{~kL}$ of solids in a tank, the waste stream must be at least 26 percent solids. Pre-1951 $1 \mathrm{C}$ waste, however, is expected to be only about 13.7 percent solids (Agnew et al. 1996a). Agnew, et al. (1996a) estimates a slightly larger waste addition volume of $6,386 \mathrm{~kL}(1,687 \mathrm{kgal})$, though not enough to account for all the solids estimated by Anderson (1990).

In 1954, a series of additions of $1 \mathrm{C}$ waste to tank $241-\mathrm{T}-104$ brought $3,900 \mathrm{~kL}(1,030 \mathrm{kgal})$ of waste into the tank (Jungfleisch 1984). (Agnew, et al. [1996a] estimates a volume of $6,711 \mathrm{~kL}[1,773 \mathrm{kgal}]$.) This $1 \mathrm{C}$ waste included coating waste and stack drainage that were combined with 1C waste after May 1951 (Agnew et al. 1996a). Coating waste was produced from the dissolution of aluminum fuel cladding in a sodium nitrate-sodium hydroxide solution. Much of this waste was cascaded to tank 241-T-105; some of the waste was pumped to other tanks. This was the last time tank 241-T-104 received waste. A supernate transfer out of the tank brought the volume to $1,830 \mathrm{~kL}$ (483 kgal). Saltwell pumping and settling of the waste brought the tank to its current waste volume of $1,408 \mathrm{~kL}$ (372 kgal). Table D3-1 uses transaction records to present an estimate of the total volume of waste that has been received by tank 241-T-104 (Jungfleisch 1984). These volumes differ somewhat from the estimates of Agnew et al. (1996a) which were presented in Appendix A

(Table A3-1).

Table D3-1. Estimated Total Volume of Waste Types Received By Tank 241-T-104. ${ }^{1}$

\begin{tabular}{|c|c|}
\hline (1) & 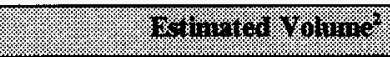 \\
\hline 1C 1944 to 1951 & $\begin{array}{l}5,360 \mathrm{~kL} \\
(1,415 \mathrm{kgal})\end{array}$ \\
\hline 1C 1951 to $1956^{3}$ & $\begin{array}{l}3,900 \mathrm{~kL} \\
(1,030 \mathrm{kgal})\end{array}$ \\
\hline
\end{tabular}

Notes:

'Jungfleisch (1984)

${ }^{2}$ Total volume is greater than $2,010 \mathrm{~kL}$ ( $530 \mathrm{kgal}$ ) because waste was routinely pumped from tank 241-T-104 and also cascaded to tank 241-T-105.

${ }^{3}$ Coating waste and stack drainage were added to $1 \mathrm{C}$ waste after May 1951. 


\section{D3.2 HISTORICAL ESTIMATION OF THE CONTENTS OF TANK 241-T-104}

A preliminary estimate of the waste constituents in tank 241-T-104 can be developed by reviewing historical data for the tank. This section uses the process history of the tank and past sampling efforts to develop an estimation of the contents of tank 241-T-104.

\section{D3.3 PROCESS HISTORY ESTIMATION}

Section D3.1 describes the history of tank 241-T-104 as repeated filling of the tank with 1C decontamination waste and cascading to tank 241-T-105 or pumping of the supernate. There is no record of any waste type other than $1 \mathrm{C}$ waste being received by the tank. However, the composition of $1 \mathrm{C}$ waste varied. As discussed in Section D3.1, coating waste and stack drainage were included in 1C waste after May 1951.

\section{D3.4 CONTRIBUTING WASTE TYPES}

$\begin{array}{ll}\text { Waste volumes }(\mathrm{kgal}) & \text { Agnew et al. (1996b): } \begin{array}{l}1946 \text { through } 1956, \\ \end{array} \\ & \text { 1C, 13,100kL }(3,460 \mathrm{kgal}) \\ & \text { Hill et al. (1995): }\end{array}$

Note: 1C, first-cycle decontamination bismuth phosphate waste, that includes bismuth phosphate cladding waste $(\mathrm{CW})$.

In the bismuth phosphate process, the $1 \mathrm{C}$ waste stream was neutralized with aluminum cladding waste. This neutralized waste stream, which contains approximately 7 percent $\mathrm{CW}$, also is commonly referred to as IC. Cascade overflows from tank 241-T-104 to tanks 241-T-105 and 241-T-106. Tables D2-1 and D2-2 compare sampling inventory estimates with HDW inventory estimates.

\section{D3.5 TECHNICAL FLOWSHEET INFORMATION}

Technical flowsheet (Kupfer et al. 1997) information for the bismuth phosphate 1C stream, which includes bismuth phosphate CW, is provided in Table D3-2. The comparative HDW model defined 1C waste stream is also provided in Table D3-2. The HDW model 1C defined waste stream appears to be a "second generation" flowsheet waste stream, derived by Jungfleisch (1984) for an earlier modeling effort (the Tracks Radioactive Components model). 
Table D3-2. Technical Flowsheet and Los Alamos National Laboratory Defined Waste Streams (Hanford Defined Waste Model).

\begin{tabular}{|c|c|c|}
\hline (1.1. & 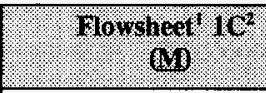 & 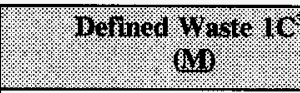 \\
\hline $\mathrm{NO}_{3}$ & 1.44 & 0.588 \\
\hline $\mathrm{NO}_{2}$ & 0.0577 & 0.174 \\
\hline $\mathrm{SO}_{4}$ & 0.0631 & 0.062 \\
\hline $\mathrm{Bi}$ & 0.0115 & 0.014 \\
\hline $\mathrm{Fe}$ & 0.0315 & 0.046 \\
\hline $\mathrm{Si}$ & 0.0312 & 0.038 \\
\hline U & 0.000963 & 0.0008 \\
\hline $\mathrm{Al}$ & 0.0826 & 0.233 \\
\hline $\mathrm{Cr}^{+3 l+6}$ & 0.00306 & 0.0062 \\
\hline $\mathrm{Ce}$ & 0.000193 & 0 \\
\hline $\mathrm{PO}_{4}$ & 0.258 & 0.334 \\
\hline $\mathrm{Zr}$ & 0.000296 & 0.004 \\
\hline $\mathrm{F}$ & 0.170 & 0.228 \\
\hline $\mathrm{Na}$ & 2.17 & 2.17 \\
\hline
\end{tabular}

Notes:

'This flowsheet stream includes Bismuth phosphate cladding waste in the 1C bismuth phosphate waste.

'Bismuth phosphate process flowsheet.

${ }^{3}$ Agnew et al. (1996b).

\section{D3.6 EVALUATION OF COMPONENT INVENTORIES}

Reference inventories of certain components in tank 241-T-104 were estimated using an engineering assessment that is based on a set of simplified assumptions. The inventories were then compared with the tank 241-T-104 sample-based inventories and the HDW model inventories. The assumptions and observations for the engineering assessment were based on best technical judgement pertaining to parameters that can significantly influence tank inventories. These parameters include: 1) correct prediction of contributing waste types and correct relative proportions of the waste types; 2) accurate predictions of model flowsheet 
conditions, fuel processed, and waste volumes; 3) accurate prediction of partitioning of components; 4) accurate predictions of physical parameters such as density, percent solids, void fraction (porosity), etc. By using this evaluation, the assumptions can be modified as necessary to provide a basis for identifying potential errors and/or missing information that could influence the sampling- and model-based inventories. Following are the simplified assumptions and observations used for the evaluation.

- Components listed in the technical flowsheets summarized in Kupfer et al. (1997) and Table D3-2 were used for the evaluation.

- Tank waste mass is calculated using the tank volume listed in Hanlon (1992) prior to the start of saltwell pumping.

- All bismuth, iron, silicon, cerium, and uranium precipitate as water insoluble components. These assumptions are based on known chemistry of the components in alkaline solutions. Chromium was assumed to precipitate as $\mathrm{Cr}(\mathrm{OH})_{3}$ or $\mathrm{Cr}_{2} \mathrm{O}_{3}\left(\mathrm{XH}_{2} \mathrm{O}\right)$ in alkaline media.

- Sodium, nitrate, nitrite, phosphate, sulfate, aluminum, and fluoride are assumed to partition between the liquid and solid phases based on known chemical solubilities and properties of compounds in alkaline solutions.

- No radiolysis of nitrate to nitrite and no additions of nitrite to the waste for corrosion purposes are factored in this independent assessment.

- Only the $1 \mathrm{C}$ bismuth phosphate waste streams which includes bismuth phosphate $\mathrm{CW}$, contributed to solids formation.

\section{D3.6.1 Solids Concentration Factor and Partition Factors for First Cycle Bismuth Phosphate Waste in Tank 241-T-104}

One method for estimating a component inventory for a particular waste type in a tank (e.g., $1 \mathrm{C}$ waste) is to derive a concentration factor (CF) for that component. This approach was used to estimate inventories in tank 241-T-104. Concentration factors are a means of reconciling process-based information and sample-based information for particular waste types. The CF is derived by dividing the concentration of a component found in the tank samples by the concentration of that component in the neutralized process waste stream (i.e., flowsheet concentrations in Table D3-2). The CF for components of a defined waste are best determined if the tank contains only one waste type (e.g., only 1C waste in tank 241-T-104) and when abundant representative analytical data are available. The relative concentrations of components expected to precipitate essentially 100 percent to the waste solids (e.g., bismuth, iron, and uranium) should be approximately proportional to the respective flowsheet concentrations for those components; i.e., these components should exhibit nearly the same CFs. If this is the case, it can generally be concluded that the sample data are consistent 
with the flowsheet basis, and thus, are quite representative of the tank contents. Since the CFs are often consistent for the same waste type in different tanks, inventories for components in tanks that do not have samples can be estimated if it is known that the defined waste is indeed present in the tank, and the volume of the defined waste is known or can be predicted.

It was noted in Assumption 3 that this evaluation assumes bismuth as well as iron, silicon, uranium, cerium, and chromium precipitate nearly 100 percent from the neutralized waste. The assumption for bismuth is based on sludge and supernatant analyses performed on typical Hanford Site tank wastes and is consistent with known chemistry for bismuth phosphate and for bismuth in alkaline solutions. The following procedure is used to calculate the CF for bismuth in tank 241-T-104. From Table D2-1, the analytical-based inventory for bismuth is $33,000 \mathrm{~kg}$, which corresponds to a bismuth concentration in the solids of $0.107 \underline{\mathrm{M}}$. The flowsheet concentration for bismuth is $0.0115 \underline{\mathrm{M}}$ (Table D3-2). The $\mathrm{CF}_{\mathrm{Bi}}$ is:

$$
\frac{0.107 \text { moles } \mathrm{Bi} / \mathrm{L}}{0.0115 \text { moles } \mathrm{Bi} / \mathrm{L}}=9.3
$$

The silicon and cerium that are expected to fully precipitate from 1C waste have CFs of 9.6 and 7.6, respectively, for tank 241-T-104. This variation for precipitated components is considered to be quite small and provides a high degree of confidence that the tank sample is representative of waste produced by the $1 \mathrm{C}$ flowsheet. However, the CFs for iron and uranium are approximately 7 and 5 , respectively, which could indicate some partitioning of these components (see Section D3.7.2).

The CFs can be quite different for different waste types. For example, the CF based on bismuth for the bismuth phosphate process 224 waste is 95 , and for second-cycle bismuth phosphate waste the CF is approximately 20 .

Once the CFs for fully precipitated components for a waste type are determined, the sample analysis can be used to establish how other components such as sulfate or phosphate partition between solids and supernatants. Concentration factors for components not expected to precipitate 100 percent can be ratioed to $\mathrm{CF}_{\mathrm{Bi}}$ to obtain the partitioning factors (PFs) for those components. The PF for any component $\mathrm{N}$, defined as $\mathrm{CF}_{\mathrm{N}} / \mathrm{CF}_{\mathrm{Bi}}$, is the fraction of $\mathrm{N}$ partitioned to the sludge.

Thus the PF for phosphate (tank 241-T-104) is:

$$
\frac{\mathrm{CF}_{\mathrm{PO4}}}{\mathrm{CF}_{\mathrm{Bi}}}=\frac{4.0}{9.3}=0.43
$$

Using this method, the estimated PFs for other components for $1 \mathrm{C}$ waste based on tank 241-T-104 are as follows when using a CF of 9.3 for fully precipitated components: 


\section{$\begin{array}{llllllll}\mathrm{Na}: & 0.17 & \mathrm{Al}: & 0.97 & \mathrm{SO}_{4}: & 0.09 & \mathrm{PO}_{4}: & 0.43\end{array}$ \\ $\begin{array}{llllll}\mathrm{NO}_{3}: & 0.09 & \mathrm{NO}_{2}: & 0.21 & \mathrm{~F}: & 0.37\end{array}$}

Several anomalies are seemingly apparent, however, when considering Assumptions 3 and 4 defined earlier in Section D3.7. The PF for aluminum is surprisingly high; i.e., based on the analytical data, it could be concluded that this component is essentially fully precipitated. As noted earlier, it was also unexpected that both iron and uranium apparently partition between the solids and supernatant. Possible explanations for these unexpected conclusions are summarized in Section D3.7.2.

The calculated CFs and PFs for tank 241-T-104 provide significant confidence that the analytical data for the tank is quite representative of the tank contents and could be used as a basis for component inventories. This is substantiated by the following:

- CFs for components in tank 241-T-104 that are expected to fully precipitate are quite consistent, which indicates that the sample likely represents the 1C flowsheet basis (Table D3-32) for the waste.

- The PFs indicate reasonable partitioning of components based on experience and knowledge of the typical chemical behavior of the components in alkaline media.

\section{D3.6.2 Inventory of Components Assumed to Precipitate 100 Percent}

The following calculations provide estimates (rounded) of tank 241-T-104 inventories for components assumed to precipitate 100 percent based on a bismuth CF of 9.3 .

Fe: $\quad 0.032$ moles Fe/ $\mathrm{L}_{1 \mathrm{C}} \times 9.3_{\mathrm{CF}(\mathrm{IC})} \times 442 \mathrm{kgal} \times 3,785 \mathrm{~L} / \mathrm{kga} \times 55.85 \mathrm{~g} /$ mole Fe $\mathrm{x}$ $\mathrm{kg} / 1,000 \mathrm{~g}=27,800 \mathrm{~kg}$

Similarly,
Si: $\quad 13,680 \mathrm{~kg}$
$\mathrm{Zr}: \quad 420 \mathrm{~kg}$
Ce: $\quad 420 \mathrm{~kg}$
U: $\quad 3,580 \mathrm{~kg}$
Cr: $\quad 2,490 \mathrm{~kg}$ 
Estimated inventories from this evaluation for components assumed to fully precipitate are compared with sample and HDW model-based inventories in Table D3-3. Observations regarding these inventories are provided by component in the following text.

Waste composition estimates for some tanks also can be developed from process flowsheets, fuel production, and waste transaction records. Tank 241-T-104, as the first tank in a three-tank cascade, is known to have received $1 \mathrm{C}$ and $\mathrm{CW}$ waste from $\mathrm{T}$ Plant from the first quarter of 1945 through the third quarter of 1954. The composition of this waste can be estimated from a spreadsheet analysis of the bismuth phosphate flowsheet, $T$ Plant fuel production records, and waste status and transaction record summaries (WSTRSs) for this tank. Altogether, tank 241-T-104 received $13,096 \mathrm{~kL}(3,460 \mathrm{kgal})$ of $1 \mathrm{C}$ and CW waste from $T$ Plant. The equivalent metric tons of uranium (MTU) can be estimated by multiplying the MTUs processed each quarter by the total fraction of $1 \mathrm{C} / \mathrm{CW}$ waste sent to tank 241-T-104. Based on this approach, tank 241-T-104 received 978.14 MTUs of equivalent $1 \mathrm{C}$ and $\mathrm{CW}$ waste. For insoluble components such as bismuth, cerium, iron, silicon, and zirconium and semi-soluble components such as aluminum, chromium, and phosphate, these values can be easily converted into equivalent waste inventory estimates for the three tank cascade. The results are summarized in Table D3-4, together with sampleand HDW model-derived estimates for tank 241-T-104.

Table D3-3. Comparison of Selected Component Inventory Estimates for Tank 241-T-104 Waste.

\begin{tabular}{|c|c|c|c|}
\hline Conponem & Thin Evaluation (kg)? & Sample Based (ko) & HDW Modil (kg) \\
\hline $\mathrm{Bi}$ & 37,400 & 37,400 & 20,300 \\
\hline $\mathrm{Ce}$ & 420 & 344 & NR \\
\hline $\mathrm{Cr}$ & 2,490 & 1,860 & 371 \\
\hline Si & 13,680 & 14,000 & 2,630 \\
\hline $\mathrm{Fe}$ & 27,800 & 19,000 & 22,400 \\
\hline $\mathrm{U}$ & 3,580 & 1,930 & 254 \\
\hline $\mathrm{Zr}$ & 420 & 80.6 & 1,280 \\
\hline
\end{tabular}

Notes:

NR $=$ Not reported.

'Based on assumptions defined in Section D3.7 and calculations in Section D3.7.1. 
Table D3-4. Comparisons Based on Fuel Production.

\begin{tabular}{|c|c|c|c|}
\hline 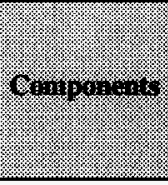 & 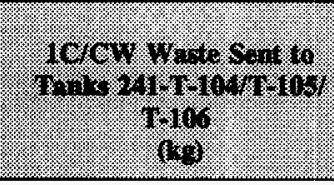 & ( & 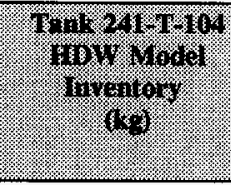 \\
\hline $\mathrm{Al}$ & 32,278 & 33,500 & 31,700 \\
\hline $\mathrm{Bi}$ & 35,213 & 37,400 & 20,300 \\
\hline $\mathrm{Ce}$ & 390 & 344 & NR \\
\hline $\mathrm{Cr}$ & 2,348 & 1,860 & 371 \\
\hline $\mathrm{Fe}$ & 25,431 & 19,000 & 22,400 \\
\hline$\overline{\mathrm{Si}}$ & 12,911 & 14,000 & 7,930 \\
\hline $\mathrm{PO}_{4}$ & 353,109 & 162,000 & 170,000 \\
\hline $\mathrm{Zr}$ & 391 & 80.6 & 1,280 \\
\hline
\end{tabular}

Note:

HDW $=$ Hanford defined waste

Bismuth. The bismuth inventory based on the core sample data is almost twice that predicted by the HDW model. The 1C defined waste from the HDW model does not differ significantly from the 1C flowsheet basis given in Table D3-2. Although the HDW model assumes that only 73 percent of the bismuth in the $1 \mathrm{C}$ waste stream precipitates, this does not account for all of the discrepancy. The CFs for other components that are expected to fully precipitate are quite consistent with those for bismuth, which indicates that the sample is likely representative of the waste produced by the bismuth phosphate process $1 \mathrm{C}$ flowsheet. Examination of process flowsheets, fuel production records, and waste transaction records provides evidence that less than $37,400 \mathrm{~kg}$ of bismuth may be in the tank. This agrees well with the sample inventory and the sample based inventory is considered to be the best basis for bismuth.

Chromium. This inventory assessment predicts the total chromium content to be fairly close to that based on the sample analysis. However, these values are approximately 5 to 7 times higher than those predicted by the HDW model. The HDW model assumes that none of the chromium precipitated in the $1 \mathrm{C}$ stream (i.e., the only chromium contribution to the solids is from the interstitial liquids associated with the solids). Additionally, because the chromium was added primarily as chromium (III) in the bismuth phosphate process, it is expected that the majority of the chromium will precipitate as $\mathrm{Cr}(\mathrm{OH})_{3}$ or $\mathrm{Cr}_{2} \mathrm{O}_{3}\left(\mathrm{XH}_{2} \mathrm{O}\right)$. 
Iron. The iron inventory predicted by this assessment is approximately 45 percent higher than the sample-based inventory. This assessment assumed that the iron would fully precipitate; however, some parititioning is likely either by loss as fine particles or (less likely) approximately 30 percent of the iron is soluble. The sample-based inventory is thus considered the best basis. The HDW inventory is slightly less than that for the sample-based inventory, although it assumes that approximately 96 percent of the iron precipitates.

Aluminum. The sample-based inventory and HDW model estimate are comparable. This assessment assumed that some aluminum would partition to the supernatant; however, the sample-based inventory for tank 241-T-104 indicates that essentially all of the aluminum precipitates. It is not surprising that most of the aluminum in $1 \mathrm{C}$ waste would partition to the solids. There is historical evidence that wastes from the bismuth phosphate process were made alkaline to an approximate $\mathrm{pH}$ of only 9 , which would promote precipitation of the metal hydroxide. If the waste was neutralized to a higher $\mathrm{pH}(\mathrm{e.g.,} 12)$, there is significant dissolution of the hydroxide with conversion to soluble sodium aluminate.

Sodium. Based on the sample analysis of tank 241-T-104, approximately 17 percent of the sodium partitions to the solids. This is somewhat lower than observed for tank 241-BX-112, which also contains $1 \mathrm{C}$ waste, which may indicate that some $\mathrm{B}$ saltcake is present in tank 241-BX-112 as predicted by the HDW model.

Silicon. The silicon inventory predicted by this assessment is approximately equal to the sample-based inventory. The silicon inventory was estimated based on the CF for bismuth. As previously mentioned, the CFs for components expected to fully precipitate should be approximately the same if the samples are representative of the waste results from the $1 \mathrm{C}$ bismuth phosphate process. It is concluded in the assessment that the sample-based inventory is reasonably close to the predicted inventory. The HDW model-based inventory is significantly lower than the sample-based inventory. The apparent explanation is that this assessment assumes that all silicon precipitates, while the HDW model assumes that only approximately 10 percent of the silicon precipitates.

Fluoride. The sample-based inventory for fluoride is approximately three times higher than the HDW model inventory. The analytical data show that a major portion of the fluoride is partitioned to the solids. This is consistent with analyses for tank 241-BX-112. The HDW model assumes that no fluoride precipitates with the solids although some remains with the interstitial liquid associated with the solids.

Uranium. The uranium inventory predicted by this assessment is approximately twice the sample-based inventory. As stated previously, it is concluded that some of the uranium partitions to the supernatant and interstitial liquid, likely as soluble uranate, but most remains with the solids. The sample-based inventory is approximately eight times higher than the HDW model-based inventory. The HDW model assumes that no uranium precipitates but that some is associated with the solids in the interstitial liquid. 
Nitrate. The sample-based inventory is approximately three times higher than predicted by the HDW model. It is surprising that the analytical-based inventory for nitrate is three times higher than that predicted by the HDW model.

Nitrite. The sample-based inventory for nitrite is approximately two times higher than predicted by the HDW model. The sample-based inventory indicates that 21 percent of the nitrite added in the $1 \mathrm{C}$ bismuth phosphate process partitioned to the solids. This partitioning was expected based on the high solubility of nitrite in the alkaline solutions.

Phosphate. The sample-based inventory for phosphate is within 3 percent of that predicted by the HDW model. Analytical data indicate that a significant portion of the phosphate in $1 \mathrm{C}$ waste partitions to the solids. The HDW model also assumes that much of the phosphate partitions.

Sulfate. The HDW model-based inventory is approximately equal to that based on the samples. The sample-based inventory for sulfate indicates that less than ten percent of the sulfate in 1C waste partitions to the solids. The HDW model predicts that all sulfate will remain soluble and will be present only in the interstitial liquids associated with the solids.

\section{D4.0 DEFINE THE BEST-BASIS AND ESTABLISH COMPONENT INVENTORIES}

Information about chemical, radiological, and/or physical properties is used to perform safety analyses, engineering evaluations, and risk assessment activities associated with waste management activities, as well as regulatory issues. These activities include overseeing tank farm operations and identifying, monitoring, and resolving safety issues associated with these operations and with the tank wastes. Disposal activities involve designing equipment, processes, and facilities for retrieving wastes and processing them into a form that is suitable for long-term storage. Chemical and radiological inventory information is generally derived using three approaches: 1) component inventories are estimated using the results of sample analyses; 2) component inventories are predicted using the HDW model based on process knowledge and historical information; or 3) a tank-specific process estimate is made based on process flowsheets, reactor fuel data, essential material usage, and other operating data. Not surprisingly, the information derived from these different approaches is often inconsistent.

An effort is underway to provide waste inventory estimates that will serve as the standard characterization for the various waste management activities (Hodgson and LeClair 1996). As part of this effort, an evaluation of available chemical information for tank 241-T-104 was performed, including the following: 
- Data from two 1992 core samples

- An inventory estimate generated by the HDW model (Agnew et al. 1996b)

- Evaluation of the $1 \mathrm{C} / \mathrm{CW}$ flowsheet and MTU comparisons.

Based on this evaluation, a best-basis inventory was developed. In general, the sample-based TCR results were preferred when they were reasonable and consistent with other results.

The best-basis inventory for tank 241-T-104 is presented in Tables D4-1 and D4-2.

Table D4-1. Best-Basis Inventory Estimates for Nonradioactive Components in Tank 241-T-104 (November 19, 1996). ${ }^{1}$ (2 Sheets)

\begin{tabular}{|c|c|c|}
\hline (1) Awhto & 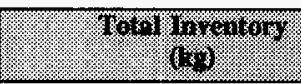 & 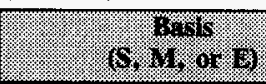 \\
\hline $\mathrm{Al}$ & 33,500 & S \\
\hline$\overline{\mathrm{Bi}}$ & 37,400 & $S$ \\
\hline $\mathrm{Ca}$ & 3,120 & $S$ \\
\hline$\overline{\mathrm{Cl}}$ & 1,440 & $S$ \\
\hline $\mathrm{TIC}$ as $\mathrm{CO}_{3}$ & 5,970 & $\mathrm{M}_{\mathrm{H}}$ \\
\hline $\mathrm{Cr}$ & 1,860 & $S$ \\
\hline $\bar{F}$ & 18,400 & $S$ \\
\hline$\overline{\mathrm{Fe}}$ & 19,000 & $\mathrm{~S}$ \\
\hline$\overline{\mathrm{Hg}}$ & 26.2 & $\mathrm{M}_{\mathrm{H}}$ \\
\hline $\bar{K}$ & 191 & $S$ \\
\hline $\mathrm{La}$ & 0.0066 & $\overline{M_{H}}$ \\
\hline Mn & 133 & $S$ \\
\hline $\mathrm{Na}$ & 134,000 & $S$ \\
\hline $\mathrm{Ni}$ & 22,600 & $S$ \\
\hline $\mathrm{NO}_{2}$ & 8,770 & $S$ \\
\hline $\mathrm{NO}_{3}$ & 125,000 & $S$ \\
\hline$\overline{\mathrm{OH}}$ & NR & \\
\hline $\mathrm{Pb}$ & 0.87 & $\mathbf{M}_{\mathrm{H}}$ \\
\hline $\mathrm{P}$ as $\mathrm{PO}_{4}{ }^{2}$ & 162,000 & $S$ \\
\hline Si & 14,000 & $\mathrm{~S}$ \\
\hline $\mathrm{S}$ as $\mathrm{SO}_{4}$ & 8,390 & $S$ \\
\hline $\mathrm{Sr}$ & 213 & $\mathrm{~S}$ \\
\hline
\end{tabular}


Table D4-1. Best-Basis Inventory Estimates for Nonradioactive Components in Tank 241-T-104 (November 19, 1996). ${ }^{1}$ (2 Sheets)

\begin{tabular}{|l|l|l|l|l|}
\hline TOC & NR & \\
\hline $\mathrm{U}_{\mathrm{TOTAL}}$ & 1,930 & $\mathrm{~S}$ \\
\hline $\mathrm{Zr}$ & 80.6 & $\mathrm{~S}$ \\
\hline
\end{tabular}

Notes:

$\begin{array}{lll}\mathrm{S} & = & \text { Sample-based } \\ \mathrm{M}_{\mathbf{H}} & = & \text { Hanford Defined Waste model-based } \\ \mathrm{E} & = & \text { Engineering assessment-based } \\ \mathrm{NR} & = & \text { Not reported }\end{array}$

${ }^{1}$ Based on 1992 core sample (see Appendix B)

${ }^{2} \mathrm{ICP}$ much higher than IC

Table D4-2. Best-Basis Inventory Estimates for Radioactive Components in Tank 241-T-104 (November 19, 1996). ${ }^{1}$

\begin{tabular}{|c|c|c|}
\hline Amwit & 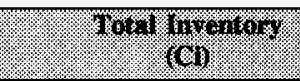 & (8, Goris or D \\
\hline${ }^{90} \mathrm{Sr}$ & 5,650 & $S$ \\
\hline${ }^{137} \mathrm{Cs}$ & 428 & $\mathrm{~S}$ \\
\hline${ }^{155} \mathrm{Eu}$ & 7.35 & $S$ \\
\hline${ }^{234} \mathrm{U}$ & $0.140 \mathrm{~kg}$ & $S$ \\
\hline${ }^{235} \mathrm{U}$ & $13.0 \mathrm{~kg}$ & $S$ \\
\hline${ }^{236} \mathrm{U}$ & $0.130 \mathrm{~kg}$ & $\mathrm{~S}$ \\
\hline${ }^{238} \mathrm{U}$ & $1920 \mathrm{~kg}$ & $S$ \\
\hline${ }^{239} \mathrm{Pu}$ & 269 & $S$ \\
\hline${ }^{240} \mathrm{Pu}$ & 32.5 & $S$ \\
\hline${ }^{241} \mathrm{Am}$ & 30.5 & S \\
\hline${ }^{241} \mathbf{P u}$ & 184 & $S$ \\
\hline
\end{tabular}

Notes:

$\begin{array}{lll}\mathbf{S} & = & \text { Sample-based } \\ \mathbf{M}_{\mathbf{H}} & = & \text { Hanford Defined Waste model-based } \\ \mathrm{E} & = & \text { Engineering assessment-based }\end{array}$

'Based on 1992 core sample (see Appendix B) 


\section{D5.0 APPENDIX D REFERENCES}

Agnew, S. F., R. A. Corbin, T. B. Duran, K. A. Jurgensen, T. P. Ortiz, and B. L. Young, 1996a, Waste Status and Transaction Record Summary for the Northwest Quadrant, WHC-SD-WM-TI-669, Rev. 1, Westinghouse Hanford Company, Richland, Washington.

Agnew, S. F., J. Boyer, R. A. Corbin, T. B. Duran, J. R. FitzPatrick, K. A. Jurgensen, T. P. Ortiz, and B. L. Young, 1996b, Hanford Tank Chemical and Radionuclide Inventories: HDW Model Rev. 3, Los Alamos National Laboratory, Los Alamos, New Mexico.

Anderson, J. D., 1990, A History of the 200 Area Farms, WHC-MR-0132, Westinghouse Hanford Company, Richland, Washington.

Hanlon, B. M., 1992, Tank Farm Surveillance and Waste Status Summary Report for September 1992, WHC-EP-0182-54, Westinghouse Hanford Company, Richland, Washington.

Hill, J. G., G. S. Anderson, and B. C. Simpson, 1995, The Sort on Radioactive Waste Type Model: A Method to Sort Single-Shell Tanks into Characteristic Groups, PNL-9814, Rev. 2, Pacific Northwest National Laboratory, Richland, Washington.

Hodgson, K. M, and M. D. LeClair, 1996, Work Plan for Defining a Standard Inventory Estimate for Wastes Stored in Hanford Site Underground Tanks, WHC-SD-WM-WP-311, Rev. 1, Lockheed Martin Hanford Corporation, Richland, Washington.

Jensen, L., R. D. Cromar, and S. R. Wilmarth, 1994, Statistical Characterization Report for Single-Shell Tank 241-T-104, WHC-SD-WM-TI-658, Rev. 0, Westinghouse Hanford Company, Richland, Washington.

Jungfleisch, F. M., 1984, TRAC: Preliminary Estimation of the Waste Inventories in Hanford Tanks Through 1980, Transaction File, SD-WM-TI-057, Rev. 0, Rockwell Hanford Operations, Richland, Washington.

Kupfer, M. J., A. L. Boldt, B. A. Higley, K. M. Hodgson, L. W. Sheiton, R. A. Watrous, S. L. Lambert, D. E. Place, R. M. Orme, G. L. Borsheim, N. G. Colton, M. D. LeClair, R. T. Winward, and W. W. Schulz, 1997, Standard Inventories of Chemical and Radionuclides in Hanford Site Tank Wastes, HNF-SD-WM-TI-740, Rev. 0, Lockheed Martin Hanford Corporation, Richland, Washington. 
HNF-SD-WM-ER-372 Rev. 1

Pool, K. N., 1994, Single-Shell Tank Waste Characterization Tank 241-T-104, Cores 45 and 46, WHC-SD-WM-DP-032, Rev. OA, Westinghouse Hanford Company, Richland, Washington. 
HNF-SD-WM-ER-372 Rev. 1

APPENDIX E

\section{BIBLIOGRAPHY FOR TANK 241-T-104}


HNF-SD-WM-ER-372 Rev. 1

This page intentionally left blank. 


\section{APPENDIX E}

\section{BIBLIOGRAPHY FOR TANK 241-T-104}

Appendix E provides a bibliography of information that supports the characterization of tank 241-T-104. This bibliography represents an in-depth literature search of all known information sources that provide sampling, analysis, surveillance, and modeling information, as well as processing occurrences associated with tank 241-T-104 and its respective waste types.

The references in this bibliography are separated into three broad categories containing references broken down into subgroups. These categories and their subgroups are listed below.

\section{NON-ANALYTICAL DATA}

Ia. Models/Waste Type Inventories/Campaign Information

Ib. Fill History/Waste Transfer Records

Ic. Surveillance/Tank Configuration

Id. Sample Planning/Tank Prioritization

Ie. Data Quality Objectives/Customers of Characterization Data

\section{ANALYTICAL DATA - SAMPLING OF TANK WASTE AND WASTE TYPES}

IIa. Sampling of tank 241-T-104

\section{COMBINED ANALYTICAL/NON-ANALYTICAL DATA}

IIIa. Inventories using both Campaign and Analytical Information

IIIb. Compendium of Existing Physical and Chemical Documented Data Sources

This bibliography is broken down into the appropriate sections of material to use, with an annotation at the end of each reference describing the information source. Where possible, a reference is provided for information sources. A majority of the information listed below may be found in the Westinghouse Hanford Company Tank Characterization Resource Center. 


\section{NON-ANALYTICAL DATA}

Ia. Models/Waste Type Inventories/Campaign Information

Anderson, J. D., 1990, A History of the 200 Area Tank Farms, WHC-MR-0132, Westinghouse Hanford Company, Richland, Washington.

- Document contains single-shell tank fill history and primary campaign/waste type information up to 1981 .

Jungfleisch, F. M. and B. C. Simpson, 1993, Preliminary Estimation of the Waste Inventories in Hanford Tanks Through 1980, WHC-SD-WM-TI-057, Rev. 0A, Westinghouse Hanford Company, Richland, Washington.

- A model based on process knowledge and radioactive decay estimations using ORIGEN for different compositions of process waste streams assembled for total, solution, and solids compositions per tank. Assumptions about waste/waste types and solubility parameters/constraints are also given.

Schneider, K. J., 1951, Flow Sheet and Flow Diagrams of Precipitation Separations Process, HW-23043, General Electric Company, Richland, Washington.

- Document contains compositions of first concentration cycle waste before transfer to 200 East Area waste tanks.

Ib. Fill History/Waste Transfer Records

Agnew, S. F., R. A. Corbin, T. B. Duran, K. A. Jurgensen, T. P. Ortiz, and B. L. Young, 1996, Waste Status and Transaction Record Summary for the Northwest Quadrant of the Hanford 200 East Area, WHC-SD-WM-TI-669, Rev. 1, Los Alamos National Laboratory, Los Alamos, New Mexico.

- Document contains spreadsheets depicting all available data on tank additions/transfers. 
Anderson, J. D., 1990, A History of the 200 Area Tank Farms, WHC-MR-0132, Westinghouse Hanford Company, Richland, Washington.

- Document contains single-shell tank fill history and primary campaign/waste type information up to 1981 .

Wicks, J. H., 1996, Saltwell Pumping of Tank 241-T-104, (internal letter 9651183 to A. B. Sidpara, March 15), Westinghouse Hanford Company, Richland, Washington.

- Document states intention to pump the saltwell of tank 2451-T-104, and lists some of the flammable gas safeguards in place.

Ic. Surveillance/Tank Configuration

Alstad, A. T., 1993, Riser Configuration Document for Single-Shell Waste Tanks, WHC-SD-RE-TI-053, Rev. 9, Westinghouse Hanford Company, Richland, Washington.

- Document shows tank riser locations in relation to tank aerial view as well as a description of riser and its contents.

Kummerer, M., 1992, Near Term Safery Study of Interim Stabilization of Watch List Tanks, WHC-SD-WM-RPT-044, Rev. 0, Westinghouse Hanford Company, Richland, Washington.

- The document estimates the expected tank inventories after interim stabilization and compares them against Watch List criteria.

Kummerer, M., 1995, Topical Report on Heat Removal Characteristics of Waste Storage Tanks, WHC-SD-WM-SARR-010, Rev. 1, Westinghouse Hanford Company, Richland, Washington.

- Document estimates the expected tank heat content based on tank temperatures.

Lipnicki, J., 1996, Waste Tank Risers Available for Sampling, WHC-SD-WM-TI-710, Rev. 3, Westinghouse Hanford Company, Richland, Washington.

- Document gives an assessment of all riser locations for each tank; however, not all tanks are included/completed. Also included is an estimate of what risers are available for sampling. 
Tran, T. T., 1993, Thermocouple Status Single-Shell and Double-Shell Waste Tanks, WHC-SD-WM-TI-533, Rev. 0, Westinghouse Hanford Company, Richland, Washington.

- Document contains information about the thermocouple status in singleand double-shell tanks.

Id. Sample Planning/Tank Prioritization

Brown, T. M., J. W. Hunt, and T. J. Kunthara, 1996, Tank Waste Characterization Basis, WHC-SD-WM-TA-164, Rev. 2, Westinghouse Hanford Company, Richland, Washington.

- Document that summarizes the technical basis for characterizing the waste in the tanks and assigns a priority number to each tank.

Creed, R. F., Test Plan for Carbonylation of 241-T-104 Waste Materials, WHC-SD-WM-TP-194, Rev. 0, Westinghouse Hanford Company, Richland, Washington.

- Document describes the process of carbonylation as a method of pretreating waste to remove iron and nickel.

Grimes, G. W., 1977, Hanford Long-Term Defense High-Level Waste Management Program Waste Sampling and Characterization Plan, RHO-CD-137, Rockwell Hanford Operations, Richland, Washington.

- Early characterization planning document.

Hill, J. G., W. I. Winters, B. C. Simpson, J. W. Buck, P. J. Chamberlain, and V. L. Hunter, 1991, Waste Characterization Plan for the Hanford Single-Shell Tanks, WHC-EP-0210, Rev. 3, Westinghouse Hanford Company, Richland, Washington.

- Document provides sampling and analysis requirements for several single-shell tanks, including tank 241-T-104. 
Kelly, S. E., 1991, Single and Double Shell Tanks for Push Mode Sampling (Rev. 1), (internal letter 72200-91-016 to N. W. Kirch, March 19), Westinghouse Hanford Company, Richland, Washington.

- Letter provides an assessment of tanks based on waste types, waste groupings, photographs of the waste surface, and previous waste sampling information, and lists tanks for a which a high percent recovery could be expected with the push mode core sampling method.

Jones, T. E., 1992, Pacific Northwest Laboratory Single-Shell Tank Waste Characterization Project (1602I) and Single-Shell Tank Safety Analysis Project (19091) Technical Project Plan, Pacific Northwest National Laboratory Richland, Washington.

- Document provides Pacific Northwest Laboratory 325 Laboratory plans for analyzing core samples from several single-shell tanks, including tank 241-T-104, in response to Silvers (1991) below.

Silvers, K. L., 1991, Sampling and Analysis of Ten Single-Shell Tanks, Statement of Work, WHC-SOW-91-0006, Rev. 1, Westinghouse Hanford Company, Richland, Washington.

- Document provides request to laboratories to perform tank core sample analyses in accordance with Hill, et al. (1991) above.

Smith, H. E., 1992, Technical Project Plan-Response to WHC-SOW-91-0006 for the 222-S Analytical Laboratory, WHC-SD-CP-TP-070, Rev. 0, Westinghouse Hanford Company, Richland, Washington.

- Document provides Westinghouse Hanford Company 222-S Laboratory plans for analyzing core samples from several single-shell tanks, including tank 241-T-104, in response to Silvers (1991) above.

Winkelman, W. D., J. W. Hunt, and L. J. Fergestrom, 1996, FY 1997 Tank Waste Analysis Plan, WHC-SD-WM-PLN-120, Rev. 0, Westinghouse Hanford Company, Richland, Washington.

- Document contains Tri-Party Agreement (see Ecology et al. 1993 listing in Section 5.0) requirement-driven TWRS Characterization Program information and a list of tanks addressed in fiscal year 1997. 
Ie. Data Quality Objectives (DQO) and Customers of Characterization Data

Dukelow, G. T., J. W. Hunt, H. Babad, and J. E. Meacham, 1995, Tank Safety Screening Data Quality Objective, WHC-SD-WM-SP-004, Rev. 2, Westinghouse Hanford Company, Richland, Washington.

- Most recent version of DQO used to determine if tanks are under safe operating conditions.

Hodgson, K. M, and M. D. LeClair, 1996, Work Plan for Defining a Standard Inventory Estimate for Wastes Stored in Hanford Site Underground Tanks, WHC-SD-WM-WP-311, Rev. 1, Westinghouse Hanford Company, Richland, Washington.

- Defines method for selecting data and method for best-basis inventory.

Kupfer, M. J., W. W. Schultz, G. L. Borsheim, S. J. Eberlein, B. C. Simpson, and J. T. Slankas, 1994, Strategy for Sampling Hanford Site Tank Wastes for Development of Disposal Technology, WHC-SD-WM-TA-154, Westinghouse Hanford Company, Richland, Washington.

- Document provides basis for selection of tanks for disposal needs.

Slankas, T. J., M. J. Kupfer, and W. W. Schulz, 1995, Data Needs and Attendant Data Quality Objectives for Tank Waste Pretreatment and Disposal, WHC-SD-WM-DQO-022, Rev. 0, Westinghouse Hanford Company, Richland, Washington.

- Documents the needs of the pretreatment function within TWRS.

\section{ANALYTICAL DATA - SAMPLING OF TANK WASTE AND WASTE TYPES}

IIa. Sampling of tank 241-T-104

Horton, J. E., 1979, Physical and Chemical Characterization of Tank 104-T, (internal letter 65124-79-017 to D. J. Flesher, November 13), Rockwell Hanford Operations, Richland, Washington.

- Internal letter provides analyses of core sample from 1979 sampling event. These results are also summarized in Mitchell (1980) and Bratzel (1980) below. 
Mitchell, M. E., 1980, Radionuclide Data on Radioactive Waste Tank Samples, (internal letter 65453-080-133 to J. R. Wetch, April 22), Rockwell Hanford Operations, Richland, Washington.

- Internal letter summarizes results of radionuclide analyses for sludge samples including those from the 1979 core sample from tank 241-T-104 documented in Horton (1979) above.

Pool, K. N., 1994, Single-Shell Tank Waste Characterization Tank 241-T-104, Cores 45 and 46, WHC-SD-WM-DP-032, Rev. 0-A, Westinghouse Hanford Company, Richland, Washington.

- Document contains sample analyses from 1992 tank 241-T-104 core sampling event.

WHC, 1996, T-104 Riser Preparation, Work Package WS-95-00291, Westinghouse Hanford Company, Richland, Washington.

- Work package contains results of tank headspace measurements made in February 1996. Vapor measurements made were flammability, total organic carbon, oxygen, and ammonia.

\section{COMBINED ANALYTICAL/NON-ANALYTICAL DATA}

IIIa. Inventories from Campaign and Analytical Information

Agnew, S. F., J. Boyer, R. A. Corbin, T. B. Duran, J. R. Fitzpatrick, K. A. Jurgensen, T. P. Ortiz, and B. L. Young, 1996, Hanford Tank Chemical and Radionuclide Inventories: HDW Rev. 3, LA-UR-96-858, Rev. 0, Los Alamos National Laboratory, Los Alamos, New Mexico.

- Document contains waste type summaries as well as primary chemical compound/analyte and radionuclide estimates for sludge, supernatant, and solids.

Allen, G. K., 1976, Estimated Inventory of Chemicals Added to Underground Waste Tanks, 1944 - 1975, ARH-CD-601B, Atlantic Richfield Hanford Company, Richland, Washington.

- Document contains major components for waste types, and some assumptions. Purchase record are used to estimate chemical inventories. 
Allen, G. K., 1975, Hanford Liquid Waste Inventory As Of September 30, 1974, ARH-CD-229, Atlantic Richfield Hanford Company, Richland, Washington.

- Document contains major components for waste types, and some assumptions.

Brevick, C. H., L. A. Gaddis, and E. D. Johnson, 1996, Historical Tank Content Estimate for the Northwest Quadrant of the Hanford 200 Areas, WHC-SD-MW-ER-351, Rev. 1, Westinghouse Hanford Company, Richland, Washington.

- Document contains summary information from the supporting document as well as in-tank photo collages and the solid composite inventory estimates Rev. 0 and Rev. $0 A$.

Brevick, C. H., L. A. Gaddis, and W. W. Pickett, 1995, Supporting Document for the Historical Tank Content Estimate for T Tank Farm, WHC-SD-WM-ER-320, Rev. 0, Westinghouse Hanford Company, Richland, Washington.

- Document contains summary tank farm and tank write-ups on historical data and solid inventory estimates as well as appendices for the data. The appendices contain the following information: Appendix C - Level History AutoCAD sketch; Appendix D - Temperature Graphs; Appendix E - Surface Level Graph; Appendix F, pg F-1 - Cascade/ Drywell Chart; Appendix G - Riser Configuration Drawing and Table; Appendix I - In-Tank Photos; and Appendix K - Tank Layer Model Bar Chart and Spreadsheet.

Hartley, S. A., G. Chen, C. A. Lopresti, T. A. Ferryman, A. M. Liebetrau, K. M. Remund, and S. A. Allen, 1996, A Comparison of Historical Tank Content Estimates (HTCE) Model, Rev. 3, and Sample-Based Estimates, PNNL-11429, Pacific Northwest National Laboratory, Richland, Washington.

- Document presents the results of a statistical comparison between sampling-based tank inventory estimates and those developed using the Hanford Defense Waste model. 
Hill, J. G., G. S. Anderson, and B. C. Simpson, 1995, The Sort of Radioactive Waste Type Model: A Method to Sort Single-Shell Tanks into Characteristic Groups, PNL-9814, Rev. 2, Pacific Northwest National Laboratory, Richland, Washington.

- Document describes a method of grouping single-shell tanks according to the amounts and types of wastes each received.

Remund, K. M., and B. C. Simpson, 1996, Hanford Waste Tank Grouping Study, PNNL-11433, Pacific Northwest National Laboratory, Richland, Washington.

- Document summarizes Hanford Tank Grouping Study efforts in fiscal year 1996. Tanks are grouped into classes with similar waste properties using analytical data.

Schmittroth, F. A., 1995, Inventories for Low-Level Tank Waste, WHC-SD-WM-RPT-164, Rev. 0, Westinghouse Hanford Company, Richland, Washington.

- Document presents tank waste inventory estimates for tanks containing low-level wastes.

Shelton, L. W., 1996, Chemical and Radionuclide Inventory for Single and Double Shell Tanks, (internal letter 74A20-96-30 to

D. J. Washnefelder, February 28), Westinghouse Hanford Company, Richland, Washington.

- Letter contains a tank inventory estimate based on analytical information.

Shelton, L. W., 1995, Chemical and Radionuclide Inventory for Single and Double Shell Tanks, (internal letter 75520-95-007 to R. M. Orme, August 8), Westinghouse Hanford Company, Richland, Washington.

- Letter contains a tank inventory estimate based on analytical information.

Shelton, L. W., 1995, Radionuclide Inventories for Single and Double Shell Tanks, (internal letter 71320-95-002 to F. M. Coony, February 14), Westinghouse Hanford Company, Richland, Washington.

- Letter contains a tank inventory estimate based on analytical information. 
IIIb. Compendium of data from other sources physical and chemical

Agnew, S. F., and J. G. Watkin, 1994, Estimation of Limiting Solubilities for Ionic Species in Hanford Waste Tank Supernates, LAUR-94-3590, Los Alamos National Laboratory, Los Alamos, New Mexico.

- Document gives solubility ranges used for key chemical and radionuclide components based on supernatant sample analyses.

Bratzel, D. R., 1980, Evaluation of Waste Storage Tank Physical and Chemical Characterization Data, (internal letter 65453-80-265, to J. M. Jungfleisch, September 18), Rockwell Hanford Operations, Richland, Washington.

- Internal letter summarizes results of radionuclide analyses for sludge samples including those from the 1979 core sample from tank 241-T-104 documented in Horton (1979) above.

Brevick, C. H., L. A. Gaddis, and E. D. Johnson, 1995, Tank Waste Source Term Inventory Validation, Vols. I \& II., WHC-SD-WM-ER-400, Rev. 0, Westinghouse Hanford Company, Richland, Washington.

- Document contains a quick reference to sampling information in spreadsheet or graphical form for 23 chemicals and 11 radionuclides for all the tanks.

Colton, N. G., 1996, Status Report: Pretreatment Chemistry Evaluation Wash and Leach Factors for the Single-Shell Tank Waste Inventory, PNNL-11290, Pacific Northwest National Laboratory, Richland, Washington.

- Document summarizes results of washing and leach studies performed on tank wastes, including tank 241-T-104, in support of tank waste pretreatment development.

Hanlon, B. M., 1996, Waste Tank Summary Report for Month Ending September, 1996, WHC-EP-0182-102, Westinghouse Hanford Company, Richland, Washington.

- These documents contain a monthly summary of fill volumes, Watch List tanks, occurrences, integrity information, equipment readings, equipment status, tank location, and other miscellaneous tank information. 
Harmon, H. D., 1992, Evaluation of High Total Organic Carbon Results in 1979 Data from Tanks 241-TY-106 and 241-T-104, (letter 9253912 to R. E. Gerton, U. S. Department of Energy, Richland Operations Office, June 8), Westinghouse Hanford Company, Richland, Washington.

- Letter cites evaluation performed in Winters (1992) below and states that the 1970 analyses of tank 241-TY-106 and 241-T-104 core samples incorrectly indicated that the tanks belonged on the Organic Watch List.

Hodgson, K. M., Evaluation of Hanford Tanks for Trapped Gas, WHC-SD-WM-ER-526, Rev. 0, Westinghouse Hanford Company, Richland, Washington.

- Document reports the evaluations of the high-level waste storage tanks for trapped flammable gas, following the methodology given in Methodology for Flammable Gas Evaluations, WHC-SD-WM-TI-724, Rev. 1. The evaluations estimate the headspace concentrations of flammable gases as a percentage of the lower flammability limit.

Husa, E. I., 1993, Hanford Site Waste Storage Tank Information Notebook, WHC-EP-0625, Westinghouse Hanford Company, Richland, Washington.

- Document contains in-tank photos as well as summaries on the tank description, leak detection system, and tank status.

Husa, E. I., 1995, Hanford Waste Tank Preliminary Dryness Evaluation, WHC-SD-WM-TI-703, Rev. 0, Westinghouse Hanford Company, Richland, Washington.

- Document gives assessment of relative dryness between tanks.

Jensen, L., R. D. Cromar, and S. R. Wilmarth, 1994, Statistical Characterization Report for Single-Shell Tank 241-T-104, WHC-SD-WM-TI-658, Rev. 0, Westinghouse Hanford Company, Richland, Washington.

- Document contains the statistical analysis of data from two core samples obtained from tank 241-T-104 in 1992. 
Jungfleisch, F. M., 1980, Hanford High-Level Defense Waste Characterization - A Status Report, RHO-CD-1019, Rockwell Hanford Operations, Richland, Washington.

- Document provides status of the characterization effort and provides core sample analytical results, including results of the 1979 core sample from tank 241-T-104 documented in Horton (1979) above.

Klem, M. J., 1990, Total Organic Concentration of Single-Shell Tank Waste, (internal letter 82316-90-032 to R. E. Raymond, April 27), Westinghouse Hanford Company, Richland, Washington.

- Letter summarizes total organic carbon concentrations for a number of single-shell tanks, including tank 241-T-104.

Richardson, D. C., 1993, Total Inorganic Carbon Content Tank 241-T-104, (letter 9350907 to R. E. Gerton, U. S. Department of Energy, Richland Operations Office, February 15), Westinghouse Hanford Company, Richland, Washington.

- Letter provides to DOE-RL and evaluation of tank 241-T-104 total organic carbon results and provides justification for not including the tank on the Organic Watch List.

Van Vleet, R. J., 1993, Radionuclide and Chemical Inventories for the Single-Shell Tanks, WHC-SD-WM-TI-565, Rev. 1, Westinghouse Hanford Company, Richland, Washington.

- Document provides an estimate of radionuclide and chemical concentrations for each single-shell tank using sampling data and TRAC model estimates.

Winters, W. I., 1992, Evaluation of High Total Organic Carbon (TOC) Results on 1979 Data Reporis from Tanks TY-106 and T-104, (internal letter 12200-A092-034 to J. D. Hopkins, April 24), Westinghouse Hanford Company, Richland, Washington.

- Letter evaluates high total organic carbon results reported for tank 241-T-104 core samples taken in 1979 and tank 241-TY-106 core samples and concludes that the data are questionable. These conclusions were transmitted from Westinghouse Hanford Company to the U. S. Department of Energy, Richland Operations Office in Harmon (1992) above. 


\section{DISTRIBUTION SHEET}

\begin{tabular}{|c|c|c|c|c|c|}
\hline \multirow{2}{*}{$\begin{array}{l}\text { To } \\
\text { Distribution }\end{array}$} & \multirow{2}{*}{\multicolumn{3}{|c|}{$\begin{array}{l}\text { sment a } \\
\text { tation }\end{array}$}} & \multicolumn{2}{|l|}{ Page 1 of 4} \\
\hline & & & & Date & $02 / 03 / 97$ \\
\hline \multicolumn{4}{|l|}{ Project Title/Work Order } & \multicolumn{2}{|c|}{ EDT No. N/A } \\
\hline \multicolumn{4}{|c|}{$\begin{array}{l}\text { Tank Characterization Report for Single-She11 Tank 241-T-104, } \\
\text { HNF-SD-WM-ER-372, Rev. 1 }\end{array}$} & \multicolumn{2}{|c|}{ ECN No. $\quad$ ECN-635429 } \\
\hline Name & MSIN & $\begin{array}{c}\text { Text } \\
\text { With All } \\
\text { Attach. }\end{array}$ & Text Only & $\begin{array}{l}\text { Attach./ } \\
\text { Appendix } \\
\text { Only }\end{array}$ & $\begin{array}{l}\text { EDT/ECN } \\
\text { Only }\end{array}$ \\
\hline
\end{tabular}

\section{OFFSITE}

Sandia National Laboratory

P.0. Box 5800

MS-0744, Dept. 6404

Albuquerque, NM 87815

D. Powers

Nuclear Consulting Services Inc.

P. 0. Box 29151

Columbus, $\mathrm{OH}$ 43229-01051

J. L. Kovach

Chemical Reaction Sub-TAP

P.0. Box 271

Lindsborg, KS 67456

B. C. Hudson

$x$

Tank Characterization Panel

Senior Technical Consultant

Contech

7309 Indian School Road

Albuquerque, NM 87110

J. Arvisu

$X$

SAIC

20300 Century Boulevard, Suite 200-B

Germantown, MD 20874

H. Sutter

$x$

555 Quince Orchard Rd., Suite 500

Gaithersburg, MD 20878

P. Szerszen

$x$ 
DISTRIBUTION SHEET

\begin{tabular}{|c|c|c|c|c|c|}
\hline \multirow[b]{2}{*}{ Distribution } & \multirow{2}{*}{\multicolumn{3}{|c|}{$\begin{array}{l}\text { Data As } \\
\text { Inte }\end{array}$}} & \multicolumn{2}{|l|}{ Page 2 of 4} \\
\hline & & & & Date & $02 / 03 / 97$ \\
\hline \multicolumn{4}{|l|}{ Project Title/Work Order } & \multicolumn{2}{|c|}{ EDT No. $N / A$} \\
\hline \multicolumn{4}{|c|}{$\begin{array}{l}\text { Tank Characterization Report for Single-Shel1 Tank 241-T-104, } \\
\text { HNF-SD-WM-ER-372, Rev. } 1\end{array}$} & \multicolumn{2}{|c|}{ ECN No. ECN-635429 } \\
\hline Name & MSIN & $\begin{array}{c}\text { Text } \\
\text { With All } \\
\text { Attach. }\end{array}$ & Text Only & $\begin{array}{l}\text { Attach./ } \\
\text { Appendix } \\
\text { Only }\end{array}$ & $\begin{array}{c}\text { EDT/ECN } \\
\text { Only }\end{array}$ \\
\hline
\end{tabular}

Los Alamos Laboratory

CST-14 MS-J586

P. 0. BoX 1663

Los Alamos, NM 87545

S. F. Agnew

$x$

Los Alamos Technical Associates

T. T. Tran

B1-44 X

Oqden Environmental

101 East Wellsian Way

Rich1and, WA 99352

R. J. Anema

$x$

CH2M Hill

P. 0. Box 91500

Bellevue, WA 98009-2050

M. McAfee

$x$

Tank Advisory Panel

102 Windham Road

Oak Ridge, TN 37830

D. 0. Campbe 11

$x$

\section{ONSITE}

Department of Energy - Richland Operations
J. F. Thompson
$57-54$
$57-54$
W. S. Liou
$57-54$
J. A. Poppiti
N. W. Willis
S7-54
$X$
$X$
$X$
$X$ 


\section{DISTRIBUTION SHEET}

\begin{tabular}{|c|c|c|c|c|c|}
\hline \multirow[b]{2}{*}{ Distribution } & \multirow{2}{*}{\multicolumn{3}{|c|}{$\begin{array}{l}\text { sment a } \\
\text { tation }\end{array}$}} & \multicolumn{2}{|l|}{ Page 3 of 4} \\
\hline & & & & Date & $02 / 03 / 97$ \\
\hline \multicolumn{4}{|l|}{ Project Title/Work Order } & \multicolumn{2}{|c|}{ EDT No. $N / A$} \\
\hline \multicolumn{4}{|c|}{$\begin{array}{l}\text { Tank Characterization Report for Single-Shel1 Tank 241-T-104, } \\
\text { HNF-SD-WM-ER-372, Rev. } 1\end{array}$} & \multicolumn{2}{|c|}{ ECN No. $\quad$ ECN-635429 } \\
\hline Name & MSIN & $\begin{array}{c}\text { Text } \\
\text { With All } \\
\text { Attach. }\end{array}$ & Text Only & $\begin{array}{c}\text { Attach./ } \\
\text { Appendix } \\
\text { Only }\end{array}$ & $\begin{array}{c}\text { EDT/ECN } \\
\text { Only }\end{array}$ \\
\hline
\end{tabular}

DE\&S Hanford, Inc.

R. J. Cash

W. L. Cowley

G. L. Dunford

G. D. Johnson

J. E. Meacham

Fluor Daniel Northwest

J. L. Stroup

Lockheed Martin Hanford, Corp.

K. M. Hodgson

T. J. Kelley

N. W. Kirch

L. M. Sasaki

B. C. Simpson

ERC (Environmental Resource Center)

Tank Characterization Resource Center

Lockheed Martin Services, Inc.

B. G. Lauzon

Central Files

EDMC

Numatec Hanford Corporation

J. S. Hertzel

D. L. Lamberd

Pacific Northwest Laboratory

J. R. Gormsen

A. F. Noonan

Rust Federal Services of Hanford, Inc.

C. T. Narquis

$\begin{array}{ll}\text { S7-- } 14 & X \\ \text { R2--54 } & X \\ \text { A2- }-34 & X \\ \text { S7-- } 14 & X \\ \text { S7--14 } & X\end{array}$

\$3-09

$x$

HO-34 X

S7-21 $\quad x$

R2-11 X

R2-12 $\quad X$

R2-12 X

R1-51 $X$

R2- $12 \quad 5$

R1-08 $\quad X$

A3-88 $\quad X$

H6- $08 \quad X$

H5-61 $X$

H5-61 $X$

$k 7-28 \quad X$

K9-91 X

$x$
$x$
$x$
$x$


DISTRIBUTION SHEET

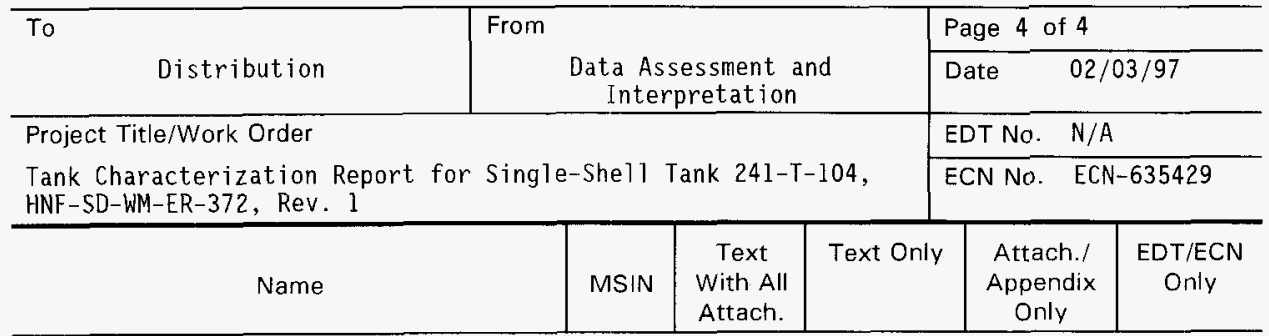

SGN Eurisys Services Corp.

D. B. Enge 7 man

L6-37 X 